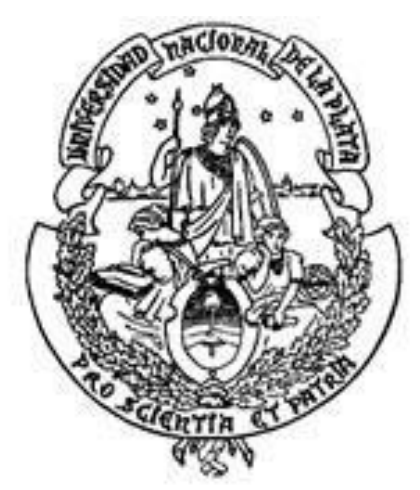

Universidad Nacional de La Plata

\title{
LAS CLAVES LINGÜÍSTICAS Y LA IMAGEN \\ VISUAL EN LA COMPRENSIÓN DE TEXTOS \\ VERBOVISUALES NARRATIVOS: EL CUENTO \\ GRÁFICO
}

Autor:

Gómez Bruno, Tatiana

Tutor:

Speranza, Adriana

Tesis presentada con el fin de cumplimentar con los requisitos finales para la obtención del título en Doctor de la Universidad de La Plata en Letras 


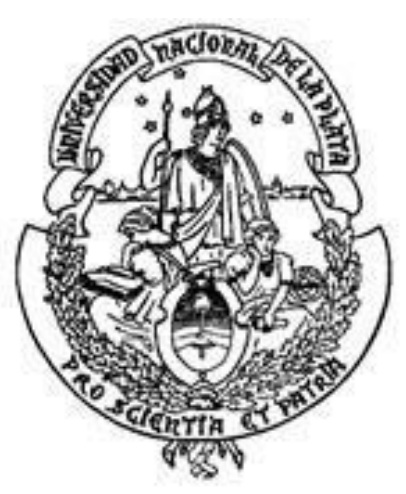

\title{
Universidad Nacional de La Plata
}

FACULTAD DE HUMANIDADES Y CIENCIAS DE LA EDUCACIÓN

\section{LAS CLAVES LINGÜÍSTICAS Y LA IMAGEN VISUAL EN LA COMPRENSIÓN DE TEXTOS VERBOVISUALES NARRATIVOS: EL CUENTO GRÁFICO}

Tesis de doctorado

Tatiana Gómez Bruno

\author{
Directora
}

Adriana Speranza 
A Camila, Ángel, Juan, Jorge y Lucina, mis flores de cerezo. 


\section{Agradecimientos}

Agradezco a las personas que me regalaron ideas, tiempo, preguntas, respuestas, ayudaron a madurar ideas y a edificar esta tesis.

A mis estudiantes que generosamente participaron de forma directa o indirecta en las diferentes etapas del estudio.

A Adriana Speranza por su ayuda en ver lo que no vi, su profesionalismo, sus palabras de amable aliento.

A mi familia que de forma invisible siempre me sostiene.

A Jorge Luis, mi padre, mi mayor fanático. 


\section{ÍNDICE GENERAL}

PARTE I

Página

\section{CAPÍTULO 0}

\section{PESQUISAS INICIALES}

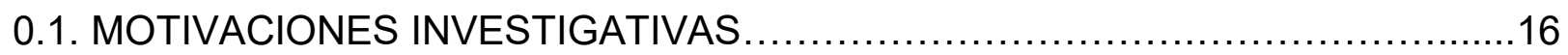

0.2. ANTECEDENTES EN LOS ESTUDIOS PSICOLINGÜÍSTICOS................... 19

0.3. OBJETIVOS GENERALES Y ESPECÍFICOS ................................. 27

0.4. HIPÓTESIS DE INVESTIGACIÓN ............................................ 28

0.5. PRECISIONES METODOLÓGICAS Y DISEÑO DE LA INVESTIGACIÓN.......... 28

0.6. ESTRUCTURA GENERAL DEL DOCUMENTO ..................................30

\section{CAPÍTULO 1}

\section{RECORRIDOS TEÓRICOS}

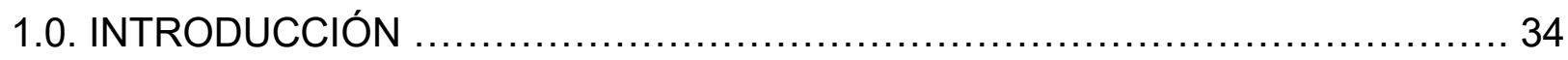

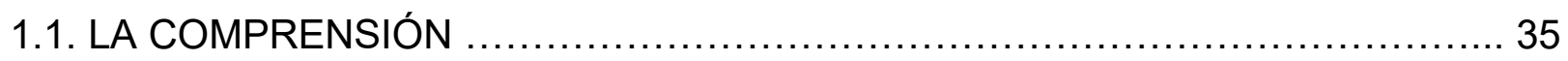

1.1.1. La memoria y el papel de la percepción en el mantenimiento de información... 42

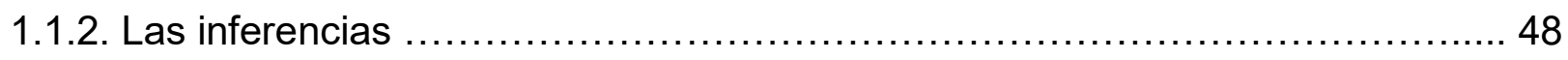

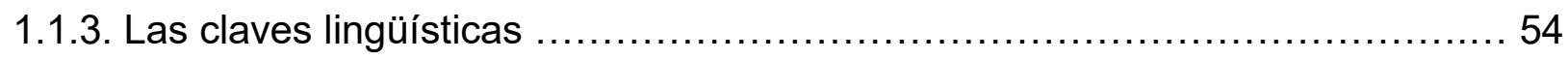

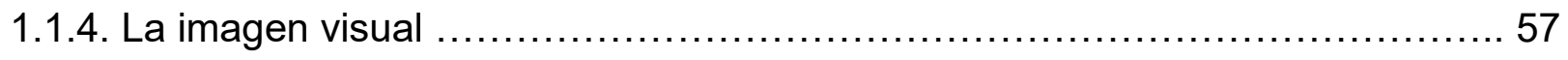

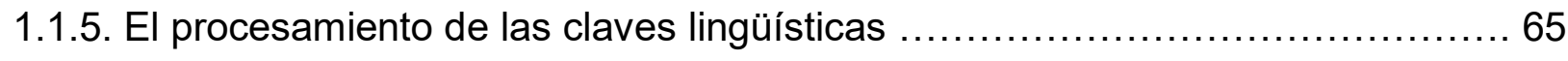

1.1.6. El procesamiento de la imagen visual ......................................... 66

1.1.7. El procesamiento de las claves lingüísticas y la imagen visual ..................68 68 


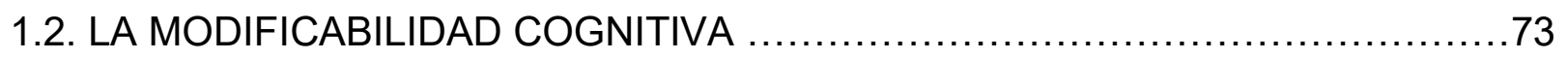

1.3. EL CUENTO GRÁFICO: ¿QUÉ ES?, ¿DE DÓNDE VIENE? ..................... 78

1.3.1. El cuento gráfico como texto multimodal y verbovisual ......................... 81

1.3.2. Estructura y comprensión del cuento gráfico .................................. 86

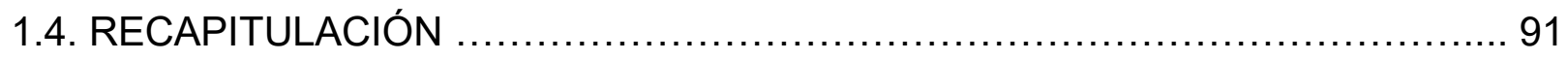

\section{CAPÍTULO 2}

RUTA METODOLÓGICA

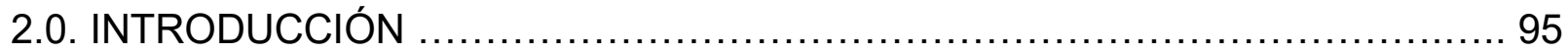

2.1. CONSIDERACIONES METODOLÓGICAS GENERALES DE LA INVESTIGACIÓN 95

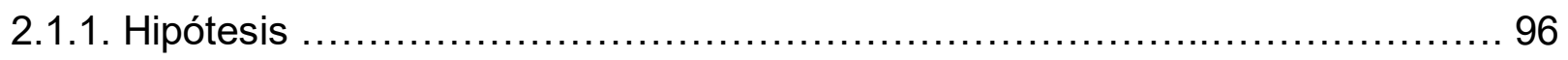

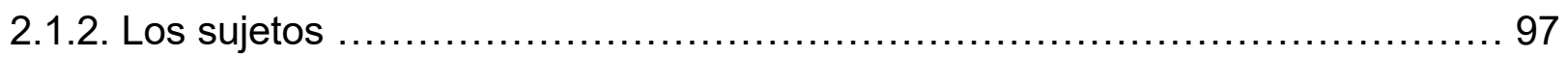

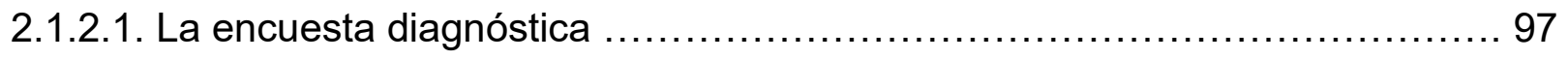

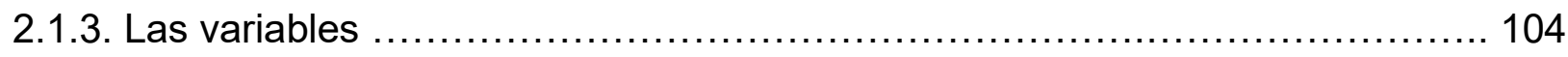

2.1.4. El estudio de caso y la triangulación .......................................... 105

2.2. CONSIDERACIONES METODOLÓGICAS PSICOLINGÜÍSTICAS ................ 109

2.2.1. Métodos de la psicolingüística ............................................ 112

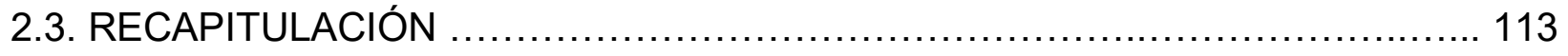

\section{CAPÍTULO 3}

\section{PROTOCOLO DE INTERVENCIÓN}

3.0. INTRODUCCIÓN 
3.1. MÓDULOS DE TRABAJO 116

3.1.1. Módulo 1. El cuento gráfico .................................................. 119

3.1.2. Módulo 2. Ejercicios cognitivos ............................................ 125

3.1.3. Módulo 3. Juegos de estrategia ........................................... 127

3.1.3.1. Juego 1. Tic, tac, boum .................................................. 128

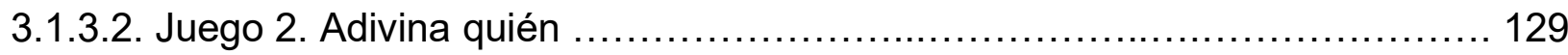

3.1.3.3. Juego 3. Puntos de colores ............................................... 130

3.1.3.4. Juego 4. Parqueadero ....................................................... 131

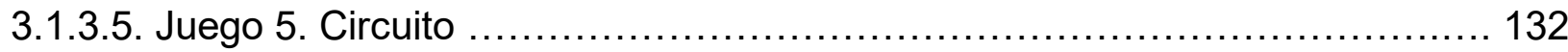

3.1.3.6. Juego 6. Lectura de imágenes ............................................. 133

3.1.3.7. Juego 7. Razonamiento abstracto ........................................... 134

3.1.3.8. Juego 8. Pingüinos memoriosos ......................................... 135

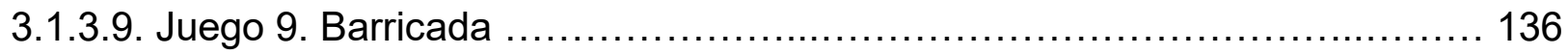

3.1.4. Módulo 4. Fundamentación sobre la imagen visual ............................ 138

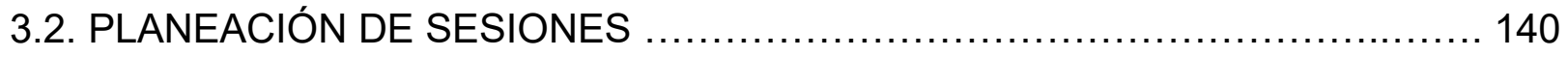

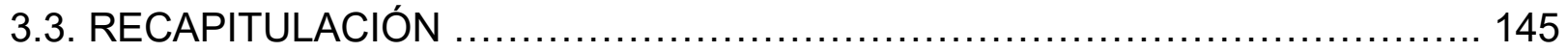

\section{PARTE II}

\section{CAPÍTULO 4}

HALLAZGOS DESDE LO CUANTITATIVO

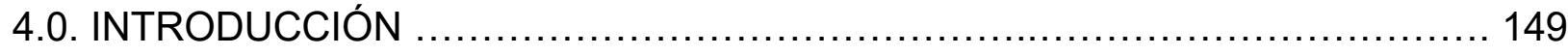

4.1. ANÁLISIS CUANTITATIVO .................................................... 149 
4.1.1. Hipótesis y subhipótesis .................................................. 150

4.1.2. Contraste de la hipótesis ...................................................... 151

4.1.2.1. Intervalos de confianza para la diferencia de proporciones entre grupos ..... 153

4.1.2.2. Análisis de curvas de aprendizaje......................................... 155

4.1.2.2.1. Curvas de aprendizaje grupales, grupo control y grupo de estudio .......... 156

4.1.2.2.2. Curvas de aprendizaje individuales, grupo control y grupo de estudio ...... 158

4.1.2.3. Análisis multivariado ........................................................... 159

4.1.2.4. Análisis de Clúster ....................................................... 166

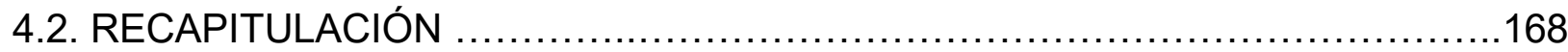

\section{CAPÍTULO 5}

\section{HALLAZGOS DESDE LO CUALITATIVO}

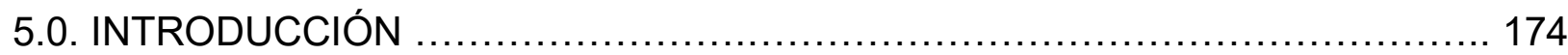

5.1. MODIFICABILIDAD EN LA COMPRENSIÓN ..................................... 174

5.1.1. Recuperación de la información, el muestreo................................. 176

5.1.2. Inferencias: predicción, anticipación, confirmación y autocorrección ............. 180

5.1.3. Reflexión y evaluación de la información ...................................... 183

5.1.4. Integración de códigos ..................................................... 185

5.2. PROCESAMIENTO DE TEXTOS VERBOVISUALES, EL CASO DEL CUENTO

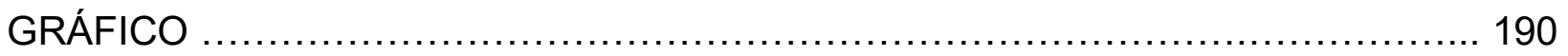

5.3. ALFABETIZACIÓN PARA LA COMPRENSIÓN DE TEXTOS VERBOVISUALES

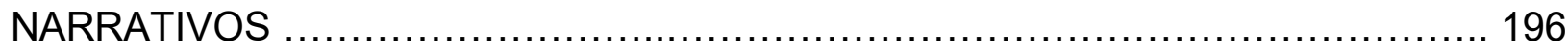

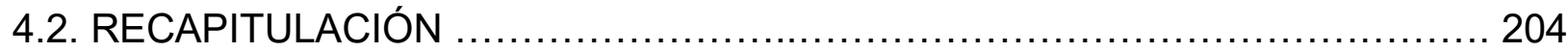


PARTE III

\section{CAPÍTULO 6}

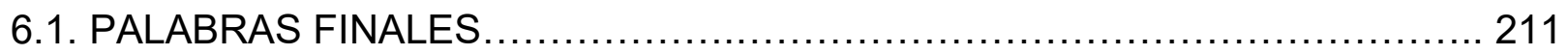

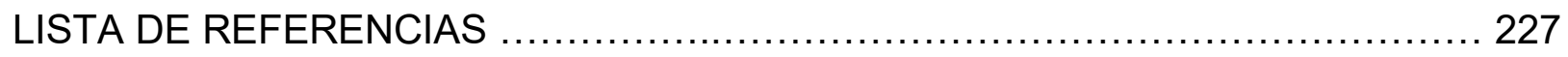

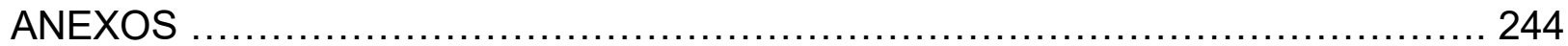




\section{LISTA DE TABLAS}

Página

Tabla 1. Síntesis de los niveles de representación según Van Dijk y Kintsch ........... 39

Tabla 2. Operacionalización de variables ............................................ 104

Tabla 3. Estructura de los módulos de trabajo ..................................... 116

Tabla 4. Planeación de sesiones del protocolo de intervención ....................... 141 


\section{LISTA DE FIGURAS}

Página

Figura 1. Modelos mentales en los procesos de comprensión de textos de Van Dijk y

Kintsch 40

Figura 2. Teoría de los esquemas de Rumelhart ................................... 41

Figura 3. Reconstrucción modelo dual de memoria de Bruning, Norby y Schrau .... 43

Figura 4. Procesamiento de la información de Atkinson y Shiffrin .................... 46

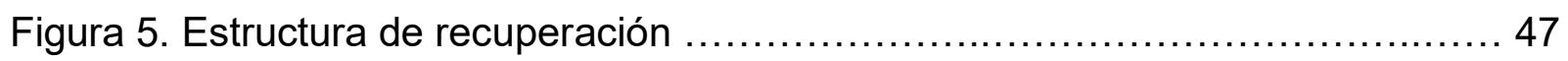

Figura 6. Modelo semántico sensorial de Nelson, Reed y Wallina .................... 72

Figura 7. ¿Qué hace que le guste un texto y termine su lectura? ...................... 98

Figura 8. Regularidad de lectura según la temática ................................. 99

Figura 9. Extensión ideal para un texto ........................................... 100

Figura 10. Preferencias en la lectura con textos que contengan letras e imágenes ..101

Figura 11. Regularidad en la lectura de caricaturas, novela gráfica, cuento gráfico,

humor gráfico, anime, manga .................................................. 102

Figura 12. Formatos en los que posee caricaturas, novela gráfica, cuento gráfico,

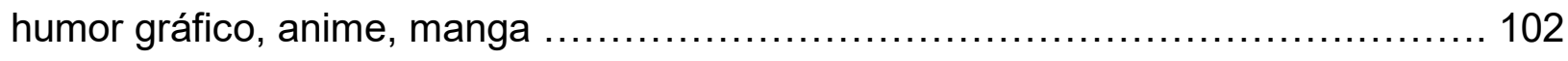

Figura 13. Juego 1. Tic, tac, boum (empresa Boing Games) ….................... 129

Figura 14. Adivina quién (empresa Hasbro Gaming) ............................... 130

Figura 15. Juego 3. Puntos de colores (empresa Entrenamiento Mental, juegos de madera) 131

Figura 16. Juego 4. Parqueadero (empresa Entrenamiento Mental, juegos de madera) 
Figura 17. Juego 5. Circuito (empresa Entrenamiento Mental, juegos de madera) ... 133

Figura 18. Juego 6. Lectura de imágenes (empresa Lee Colombia) .................. 134

Figura 19. Juego 7. Razonamiento abstracto (empresa Lee Colombia) ............... 135

Figura 20. Juego 8. Pingüinos memoriosos (empresa Entrenamiento Mental, juegos de

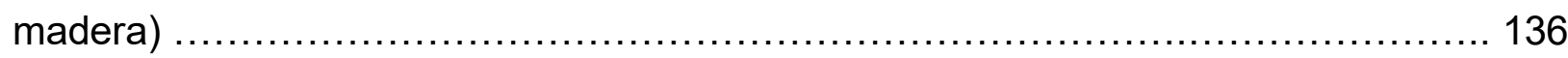

Figura 21. Juego 9. Barricada (empresa Entrenamiento Mental, juegos de madera) .137

Figura 22. Curva de aprendizaje. Grupo control...................................... 156

Figura 23. Curva de aprendizaje. Grupo estudio .................................... 157

Figura 24. Curva de aprendizaje por sujeto. Grupo control.......................... 158

Figura 25. Curva de aprendizaje por sujeto. Grupo estudio .......................... 159

Figura 26. Pretest, plano factorial simultáneo ........................................ 161

Figura 27. Monitoreo 1, plano factorial simultáneo ................................. 162

Figura 28. Monitoreo 2, plano factorial simultáneo ................................... 163

Figura 29. Monitoreo 3, plano factorial simultáneo ….............................. 164

Figura 30. Post test, plano factorial simultáneo .................................... 165

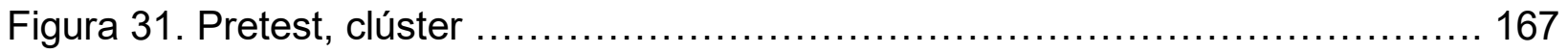

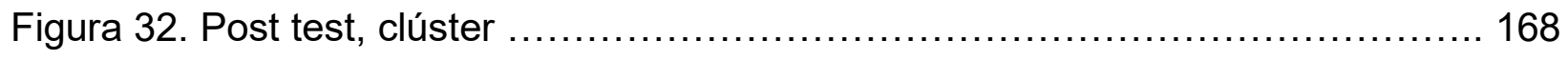

Figura 33. Modelo de procesamiento verbovisual ................................... 191

Figura 34. Modelo de alfabetización verbovisual .....................................199 


\section{LISTA DE ANEXOS}

Página

ANEXO 1. Prueba pretest. El testamento del señor Morris (Boix, 2009, 59-65) ....... 244

ANEXO 2. Prueba de monitoreo 1. El secreto de la cañada de Macarger (Lalia, 2008B,

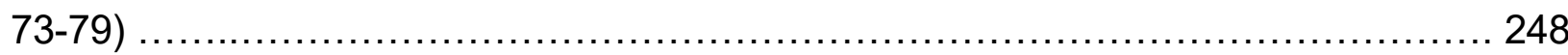

ANEXO 3. Prueba de monitoreo 2. El mal (Boix, 2009, 86-90) ….................... 252

ANEXO 4. Prueba de monitoreo 3. El estúpido humano (Boix, 2009, 78-85) ........... 256

ANEXO 5. Prueba post test. La fobia (Boix, 2009, 91-98) ............................ 260

ANEXO 6. Consentimiento informado para proyectos de investigación ................ 264

ANEXO 7. Encuesta diagnóstica para identificar conocimiento previo de los sujetos 267

ANEXO 8. Base de datos de pruebas pretest y post test del grupo estudio y control 269

ANEXO 9. Base de datos de pruebas monitoreo grupo estudio ...................... 270

ANEXO 10. Ejemplos de ejercicios cognitivos (Fonseca, 1995; NGV, s. f.) ............ 271

ANEXO 11. Rúbricas para la construcción de pruebas .............................. 275 
PARTE I 


\section{CAPÍTULO 0}

PESQUISAS INICIALES 


\subsection{MOTIVACIONES INVESTIGATIVAS}

La reflexión sobre la evolución de la imagen, su creciente protagonismo, su ausencia de reconocimiento y trabajo en los contextos escolares y académicos, asociada al trabajo didáctico con ciertos tipos textuales considerados formales y propios de la academia, llevan irremediablemente a cuestiones sobre la presencia o la ausencia de una "educación para la imagen", del conocimiento e interpretación de los códigos de la comunicación gráfica en los que por requisito disciplinar la imagen no es protagonista. En tiempos en que la imagen tiene mayor presencia, la necesidad de conocer su lenguaje y desentrañar sus significados es una necesidad mayor.

La era digital ha permitido el posicionamiento de la imagen. La escuela debe brindarles a los estudiantes una experiencia que posibilite desarrollar y refinar los procesos cognitivos que faciliten la comprensión de textos en los que se empleen imágenes visuales. Arizpe y Styles (2004) afirman que:

[...] Vivimos en un mundo cada vez más visual, en el que se acepta de buen grado que las imágenes superen a las palabras como el medio de comunicación predominante. La mayor parte de los niños contemporáneos afortunados que tienen acceso a videos, computadoras y juegos electrónicos dominan sus alcances y repertorios con una facilidad y destreza que asombra a sus mayores, más torpes que ellos. (p. 15)

Muy a pesar de tales facilidades en el sistema educativo prima el interés por comprender las claves lingüísticas, si se emplean textos multimodales se estudia la imagen, el sonido y la letra cada uno por separado, terminando en análisis 
monomodales ${ }^{1}$. Los sujetos, aunque están inmersos en contextos plagados de imágenes visuales, necesitan cambiar la forma cómo interactúan con ese tipo de sistema semiótico y se les deben proporcionar las herramientas para hacerlo. En consecuencia, es apremiante conocer sobre cómo hacen los sujetos para comprender los textos verbovisuales y proponer formas de trabajo que permitan su alfabetización.

En el caso de Colombia, se identificaron tres situaciones agravantes. La primera, no hay una tradición de lectura de textos verbovisuales narrativos como el cuento gráfico, lo que implica poca comercialización y presencia de este tipo de textos en bibliotecas o librerías, aunque es importante mencionar que los jóvenes entre 10 y 20 años cada vez más manifiestan interés por acceder a ellos. La segunda, en las pruebas internas y externas aplicadas a los estudiantes de todos los niveles educativos se ha incrementado el uso de textos verbovisuales expositivos y narrativos, lo cual exige un trabajo riguroso de acompañamiento que proporcione a los estudiantes las herramientas necesarias para su abordaje. La tercera, la gran mayoría de los docentes se concentran en trabajar con sus estudiantes la comprensión de textos monomodales (verbales), sea por la preservación de la concepción ortodoxa de lo que se debe enseñar de espalda a las trasformaciones de las realidades discursivas a las que se ven expuestos los sujetos, o por el desconocimiento de los elementos conceptuales y didácticos sobre la imagen y los elementos cognitivos asociados a su procesamiento.

Cuando se lee un texto verbovisual narrativo, ¿cómo se hace?, ¿qué se lee primero, las claves lingüísticas o la imagen visual, cómo se relacionan?, ¿qué se hace

\footnotetext{
1 La monomodalidad corresponde a la existencia de un modo o sistema semiótico en un texto, especialmente la letra. Por otra parte, la multimodalidad se refiere a la presencia simultánea de diversos modos, tal es el caso de la imagen, la letra, el sonido, el gesto, entre otros (Kress y Van Leeuwen, 2001). Parodi propone el concepto de multisemiótico indicando que en un texto conviven sistemas semióticos que poseen características especiales para crear signos (Parodi, 2010).
} 
antes, durante y después de su lectura?, ¿cómo, cuándo y para qué se emplea el conocimiento previo?, ¿cómo influye la familiarización con el cuento gráfico al momento de comprender?, ¿qué aspectos se analizan en las imágenes visuales?, ¿si se ejecuta un plan de intervención para mejorar los procesos de comprensión, qué aspectos cognitivos se modifican en los sujetos?, ¿qué debe priorizarse para que la comprensión sea efectiva?, ¿al momento de leer en qué se invierte más tiempo?, ¿cuándo se lee, se relaciona el texto con otros textos leídos anteriormente, cómo y por qué?, ¿cuándo se lee, se pueden diferenciar las ideas esenciales y las ideas de apoyo en el texto, en qué aspectos se dificulta, cómo se soluciona? Estas son preguntas de obligada reflexión al estudiar las claves lingüísticas y la imagen visual en la comprensión de textos verbovisuales narrativos: el cuento gráfico.

En este orden de ideas, la propuesta que se presenta se hace con finalidades a largo plazo, cada una de las elecciones se basan en la observación de situaciones en el contexto educativo y la lectura de literatura asociada al problema. Se identifica la necesidad del estudio y las utilidades teóricas y pedagógicas. Por tanto, se constituye en una contribución a la investigación. Los procedimientos sirven de modelo para trabajos similares; los resultados enriquecen el marco teórico general de la psicolingüística y, en consecuencia, de la lingüística de la comunicación; además, se erige como un intento explicativo de las formas de representar la información y usar el conocimiento para interpretar las realidades discursivas que rodean a los sujetos. 


\subsection{ANTECEDENTES EN LOS ESTUDIOS PSICOLINGÜÍSTICOS}

En el marco de la psicolingüística se han realizado estudios sobre la comprensión de textos verbales y verbovisuales, en algunas ocasiones se asocia al género textual. A continuación, se reseñan los más significativos para la presente investigación.

En cuanto a la información textual -imagen visual y claves lingüísticas- se destacan investigaciones realizadas desde 1976 a la fecha. Es difícil identificar un perfil en estos estudios, dado que se desarrollan en una amplia gama de intereses académicos que van desde la determinación de un modelo semántico sensorial, el impacto de la codificación visual en los procesos de lectura, las propiedades tridimensionales de la imagen visual, la percepción de la imagen visual, la memoria pictórica, el procesamiento imagen visual-palabra, el papel de la memoria implícita y explícita en la interpretación de dibujos fragmentados, las inferencias visuales según técnicas gráficas hasta el impacto de la visualización de imágenes afectivas. Inmediatamente se referencian algunas de estas investigaciones.

Nelson et al. (1977) proponen un modelo semántico sensorial, resaltan que la mayor efectividad de las imágenes se debe, por un lado, al acceso directo de las imágenes al contenido semántico; de tal manera que el material pictórico favorece el almacenamiento y la recuperación de información en la memoria a largo plazo y produce codificaciones cualitativamente diferentes al material verbal.

Sánchez Meca e Hidalgo Montesinos (1990) abordan las implicaciones de la codificación visual en el retraso específico en la lectura. El objetivo es determinar la importancia de la automaticidad y la eficiencia de los procesos de codificación visual en 
el aprendizaje de la lectura. La tarea informatizada de exploración de letras la ejecutan 40 niños con discapacidad cognitiva y 40 niños normales, entre 6 y 9 años. Los autores buscan responder cómo codificamos la información visual y de qué forma afecta el procesamiento de la información. Los resultados revelan que los niños con discapacidad cognitiva al momento de leer muestran menor velocidad y precisión debido a dificultades en la codificación visual. En consecuencia, para procesar de forma efectiva se debe contar con los procesos consolidados de codificación visual que permiten el aprendizaje la lectura.

Pérez (1994) estudia las propiedades tridimensionales de la escena visual y la discriminación preatentiva de texturas. Analiza los efectos de tales propiedades en la identificación del tipo de texturas formadas por patrones de fondo blanco y negro. Los datos arrojan que las relaciones espaciales (perspectiva lineal) y de intensidad (sombreado) trasmiten información tridimensional, importante para la interpretación de textos.

Campos y González (1994) estudian la relación entre imagen visual, inteligencia y creatividad. Identifican que existe relación entre la influencia de la viveza de imagen visual (entendida como la claridad del texto visual, el realce de los detalles que permite su lectura con facilidad) y de la inteligencia sobre creatividad. En el experimento participan 331 estudiantes de bachillerato y se les aplica el test Vividness of visual imageney. Los autores concluyen que los sujetos con mayor coeficiente intelectual valoran la originalidad en la imagen y pueden rastrear en ella los detalles a pesar de la viveza baja; por su parte, los sujetos con coeficiente intelectual bajo se apoyan en las imágenes mentales. Los resultados no son concluyentes. 
Ballesteros (1999) aborda la memoria humana, dando cuenta de las investigaciones y las posiciones teóricas más destacadas. La autora afirma que después de la realización de varios experimentos puede identificar que el procesamiento de la información varía según las modalidades y la relación entre ellas. Determina que se presentan diferencias entre el procesamiento de información pictórica e información verbal y entre relaciones intermodal (visión-tacto / tacto-visión) e intramodal (visión-visión / tacto-tacto); se concentra en la intermodalidad combinando lo pictórico y lo verbal. Precisa que el procesamiento exigido en tal caso puede explicarse desde la teoría de acceso diferencial y la teoría de codificación dual. La primera remite al hecho que los sujetos ante dibujos o palabras deben acceder a distintos sistemas semánticos con distintas relaciones asociativas y semánticas; la segunda argumenta que existen dos tipos de representación en dos sistemas diferentes, su divergencia está en el orden en el que se produce el acceso a la representación. Además, rescata la importancia de la memoria icónica, la cual se encarga de almacenar los registros sensoriales de gran capacidad, que pueden ser: visual y auditivo.

Ballesteros (1999) asevera que un procedimiento muy utilizado para afrontar el problema de la representación de dibujos y palabras ha sido el de facilitación (priming) empleando combinaciones de dibujos y palabras como estímulos objetivo (target) y de preparación (prime). Emplear la técnica priming implica analizar el efecto que tiene un estímulo $\mathrm{A}$ en el rendimiento subsiguiente del sistema de procesamiento de un estímulo B, recurrir a la memoria implícita para la realización de las tareas porque se acude a los conocimientos y las experiencias previas, lo aprendido por el sujeto se establece como la base para realizar asociaciones entre estímulos y recuperar información. El prime se 
erige como el estímulo de preparación para activar la información, es el elemento que manipula el experimentador; el target es el dibujo, la palabra o el morfema que se genera luego del prime y que tiene alta probabilidad de aparecer porque se encuentra asociado por diferentes redes.

En los procedimientos de facilitación normalmente se presenta un primer estímulo (de preparación) que está relacionado en alguna dimensión (semántica, asociativa, fonética, visual) con el estímulo ante el que el sujeto debe responder (objetivo). En la medida que la dimensión por la que los dos estímulos están relacionados es común a ambos y relevante para la tarea que se ha de realizar, la presencia de un estímulo previo relacionado debe facilitar la respuesta ante el estímulo objetivo, de manera que si se compara esta condición a un control en que el estímulo previo no está relacionado la respuesta se produce con mayor rapidez. Se demuestra que existe facilitación cuando la relación que guardan los dos estímulos es efectiva y relevante para la tarea, y la actuación es mejor comparada con una condición control en la que no existe esa relación entre los dos estímulos (Ballesteros, 1999; Beato et al., 2006).

Sebastián y Menor (1999) desarrollan un trabajo sobre la evaluación de la memoria implícita mediante la tarea de identificación perceptiva de dibujos fragmentados. El fin es comparar si cuatro formas de dibujos fragmentados de Snodgrass y Corwin (1988) son equivalentes entre sí en una población española. Realizan un primer experimento de identificación perceptiva de imágenes más o menos fragmentadas y un segundo experimento de recuerdo libre de la versión completa. Las tareas exigen que los sujetos confronten la memoria implícita (manifestaciones no 
conscientes, evaluadas con pruebas indirectas) y la memoria explícita (recuperación voluntaria y consciente, valoradas con pruebas directas). Se llega a dos conclusiones, primero, que ni el aprendizaje perceptivo, ni el aprendizaje por destreza es homogéneo; segundo, la nominación de la imagen, la variabilidad de la imagen y la familiaridad no influyen en la memoria, y si lo hacen dificultan el recuerdo.

Bajo et al. (1999) indagan por la representación semántica y fonológica de dibujos y palabras. El objetivo es determinar si al momento de procesar dibujos y palabras se presenta acceso diferencial o sistemas de memoria. Los procedimientos empleados son la facilitación semántica y fonológica con distintas combinaciones de dibujos y palabras. Los resultados muestran que el patrón de facilitación depende del tiempo de presentación del estímulo de preparación (prime). Cuando los estímulos se presentan durante $1000 \mathrm{~ms}$ (1 segundo), la presencia de facilitación depende de la tarea, de la modalidad del estímulo objetivo y de factores estratégicos. Con tiempos de presentación de $32 \mathrm{~ms}$, los cambios de modalidad entre el estímulo de preparación y objetivo son relevantes. Con $50 \mathrm{~ms}$, aparecen los primeros efectos de facilitación semántica, pero sólo cuando el estímulo previo era un dibujo.

Morales et al. (2000) desarrollan un trabajo basado en la aplicación de la teoría de la detección de señales de análisis de la inferencia visual de series de tiempo utilizando diseños de respuestas múltiples. El objetivo es estudiar si la evaluación de la efectividad de un tratamiento mediante la inspección visual depende del tipo de representación gráfica. Los resultados muestran que los sujetos se equivocan con mayor frecuencia con líneas y barras que con cajas, lo que indica que tal variación depende de la técnica gráfica y de si los estímulos resultan efectivos o no efectivos. 
Sánchez et al. (2002), exploran la modulación emocional de los reflejos defensivos mediante la visualización de imágenes afectivas. Para ello, analizan la respuesta cardíaca de defensa y de reflejo motor de sobresalto (parpadeo), evocados por estímulos acústicos y la visualización simultánea de imágenes afectivas (agradables y desagradables) seleccionadas de la adaptación española del International Affective Piscture System. Las respuestas se evalúan como subjetivas fuesen verbales, conductuales y fisiológicas. Los resultados evidencian potenciación de la respuesta cardiaca de defensa y del reflejo motor de sobresalto ante la visualización de las imágenes desagradables. La visualización de imágenes agradables produce inhibición, en comparación con la visualización de imágenes neutrales, sólo en el caso del reflejo motor de sobresalto.

En cuanto al género, León (2003) sostiene que es esencial porque determina los tipos de inferencias que se construyen, los tiempos de lectura y la manera cómo se comprende un texto. Cuando se habla de género se refiere al tipo de texto en cuestión. Hay una variabilidad de clasificaciones, pero la más estándar está conformada por textos descriptivos, expositivos, narrativos, persuasivos y procedimentales. Bajtín (1986) indica que los géneros no son estructuras fijas y se cimientan socialmente, lo que implica que el que escribe o habla deje señales al que lee o escucha, se ancla el discurso a interacciones comunicativas específicas. Entonces, los géneros se adaptan a acciones, eventos y respuestas; son una ritualización de las acciones sociales que se transforman en acciones discursivas, los sujetos crean y se adhieren a normas que permite la construcción a partir de la interacción de formas prototípicas del discurso, que llamamos géneros. Al respecto León (2003) afirma que "La configuración propia de 
los géneros en situaciones prácticas y concretas va generando una dinámica muy vinculada entre la cognición, por un lado, y la praxis, la realidad y formas genéricas del discurso, por otro" (p. 156).

En los repositorios bibliográficos de las universidades o en los artículos científicos se encuentran referenciadas investigaciones sobre la comprensión y el género pero su enfoque es mayormente didáctico. En cuanto a los estudios psicolingüísticos, la gran parte se centra en los textos expositivos y narrativos por la cotidianidad de su uso y dado que los sujetos están más expuestos a ellos. El eje de trabajo es la identificación de las inferencias y las estrategias que se utilizan en su procesamiento.

En los textos expositivos se enfrenta al lector ante información nueva, realidades genéricas y abstractas, de carácter más técnicas. Posibilitan la activación de conocimiento previo, la relación entre ideas, la interpretación de secuencias, la generación de preguntas, la comparación entre datos, la generalización, la metacomprensión y la identificación de ideas centrales, se enfatiza en entender el significado de elementos locales lo que dificulta su posterior vinculación. El estudio del texto argumentativo poco se ha abordado, pero en la literatura citada se indica que se caracteriza por presentar opiniones que se rebaten con el fin de convencer o persuadir, forjar predicciones, favorecer la construcción de premisas, argumentos, juicios, reacciones emocionales, evaluaciones, asociaciones. El texto narrativo exige el uso de estrategias de integración y procesamiento global; suele presentar información y hechos que resultan familiares; favorece la identificación de intenciones, genera reacciones emocionales; se anticipa al rastreo de datos sobre lugares, espacios y 
tiempos; permite crear el perfil de los personajes a partir de las características físicas y psicológicas (León, 2003,1991, 2007; Kintsch,1993; Graesser y Kreuz, 1993; Magliano y Graesser, 1991; McKoon y Ratcliff, 1992; Graesser y Bower, 1990; Muth, 1990). Por tanto, el proceso de comprensión que se desarrolla en los sujetos no es generalizable ni único para todos los tipos de textos porque hay factores pragmáticos asociados a la memoria implícita que van más allá de los aspectos lingüísticos. Si los sujetos reconocen la estructura y la función inherente a los géneros tendrán mayor probabilidad de éxito en su comprensión, además, cada tipo enfrenta al lector a demandas distintas y exige estrategias específicas que se ajustan a los propósitos de la lectura, y deben ser estudiados a profundidad.

Villa (2008) desarrolla una propuesta de alfabetización visual para estudiantes de educación básica apoyada en recursos hipermediales. Afirma que casi siempre los docentes se centran en promover en los estudiantes la comprensión de textos verbales como parte fundamental del proceso de enseñanza y aprendizaje, relegando a un segundo plano las imágenes que los acompañan. Lo expresado se puede deber a una concepción tradicional de la comprensión lectora pese al protagonismo de las imágenes. Trabaja con 32 estudiantes de séptimo grado de una institución pública de la ciudad de Medellín-Colombia, por tres meses, 4 horas semanales. Se usa un entorno hipermedial diseñado específicamente con el propósito de favorecer la lectura de imágenes. Se logra que los estudiantes eleven su capacidad para identificar los elementos morfosintácticos y connotativos de las imágenes; parten de un nivel básico, pasan durante la experiencia por un nivel medio, y la mayoría de ellos alcanzan un nivel avanzado al concluir la experimentación. 
Arizpe y Styles (2004) realizan un estudio con la participación de niños de diversos entornos culturales y económicos. Diseñan entrevistas, debates, talleres de producción escrita e interpretación a partir de álbumes infantiles de Anthony Browne y Satoshi Kitamura. Su idea central es que los niños son expertos en leer imágenes y los álbumes ilustrados les permiten fortalecer su potencial de alfabetización visual. Estudiaron la atracción de las imágenes, la dimensión afectiva, los factores culturales y el género en contraste con la oralidad, el pensar y el saber.

En las investigaciones reseñadas se trabaja comprensión, inferencias, relación imagen visual-palabra, pero no se encuentra una propuesta similar a la desarrollada; lo anterior le proporciona validez en la medida que se constituye en un aporte novedoso al campo de la psicolingüística.

\subsection{OBJETIVOS GENERALES Y ESPECÍFICOS}

El objetivo general de la investigación es explicar, desde los planteamientos de la psicolingüística, la incidencia de las claves lingüísticas y la imagen visual en la comprensión de textos narrativos verbovisuales como el cuento gráfico. Para lograrlo se proponen tres objetivos específicos: primero describir el proceso realizado por los sujetos de estudio cuando comprenden textos verbovisuales narrativos; segundo, comparar el procesamiento de las claves lingüísticas y la imagen visual en la comprensión de textos verbovisuales narrativos; tercero, analizar la relación entre las claves lingüísticas y la imagen visual en la comprensión de textos verbovisuales narrativos. 


\subsection{HIPÓTESIS DE INVESTIGACIÓN}

De acuerdo con los antecedentes de las investigaciones psicolingüística sobre comprensión y los objetivos, la hipótesis de la que se parte y se intenta confirmar es la siguiente: La información de carácter visual resulta subsidiaria del procesamiento de la información verbal y requiere, al igual que esta última, de estrategias para su análisis. El desarrollo de estrategias específicas en el sujeto lector favorece la comprensión del texto verbovisual.

\subsection{PRECISIONES METODOLÓGICAS Y DISEÑO DE LA INVESTIGACIÓN}

En la investigación participan 20 estudiantes universitarios organizados de forma equitativa en grupo control y grupo estudio -intervenido-, se les aplica una prueba pretest y una prueba post test. Adicionalmente, para los miembros del grupo estudio se diseña una intervención de 14 sesiones con una duración de tres horas, en ellas resuelven ejercicios cognitivos, solucionan juegos de estrategia, reciben alfabetización sobre aspectos claves de la imagen visual, interactúan en actividades de club de lectura a partir de cuentos gráficos sugeridos, y se les administran tres pruebas de monitoreo. Conceptualmente se parte de los postulados de Feuerstein et al. (1999) quienes proponen la teoría de la modificabilidad cognitiva en la que se establece que cualquier individuo al interactuar con los estímulos adecuados, material intencionalmente seleccionado, tareas progresivas, motivación del aprendiz y un mediador experto, puede lograr aprendizajes articulados a cambios estructurales y a largo plazo. 
Considerando los objetivos y la hipótesis que se han planteado, la perspectiva metodológica de investigación escogida es mixta, cualitativa-cuantitativa de naturaleza cuasiexperimental (Bono Cabré, s.f.). Se recolectan datos a través del protocolo de intervención, las pruebas de comprensión se someten a análisis estadísticos para validar la hipótesis; los datos no estructurados y heterogéneos se examinan para dar cuenta del proceso y proporcionar explicaciones fundamentadas desde la teoría relacionada.

En la investigación se emplea el estudio de caso desde la perspectiva de Merrian (1998). El interés es analizar en profundidad la comprensión de textos verbovisuales narrativos, las acciones planeadas recaen sobre el proceso desarrollado por los estudiantes más que en los resultados de las actividades que resuelven. Por lo anterior, se realizan descripciones y análisis intensivos de los desempeños de la población participante a partir de la información recolectada en la intervención. Se emplea el estudio de caso psicológico porque particulariza y permite estudiar a detalle el fenómeno en un tiempo determinado concentrándose en los desempeños de los sujetos. Además, es descriptivo e interpretativo, el primero porque da cuenta del fenómeno que se estudia; el segundo porque los datos descriptivos se utilizan para desarrollar y respaldar categorías conceptuales (Ragin, 2000).

Teniendo en cuenta la perspectiva metodológica mixta y los datos que se recolectan gracias a diferentes técnicas (entrevistas, observaciones, encuestas, diario de campo), se acude a la triangulación para alcanzar precisión, contar con caminos alternativos y estrategias que no dependen de la intuición. Con la triangulación se puede encontrar el mismo resultado en diferentes fuentes y circunstancias, de tal forma 
que se aumentan las fortalezas y la calidad del estudio, debido a que se produce información redundante, esclarecen significados y verifica repetitividad, en otras palabras, se emplean diferentes métodos para visualizar un fenómeno ampliamente y se evita las fallas metodológicas (Flyvbjerg, 2004). La variable dependiente es modificabilidad en la comprensión. La variable independiente es la intervención verbovisual, centrándose en el cuento gráfico. Como variable interviniente se tiene en cuenta el conocimiento previo de los estudiantes y el grado de exposición a los textos mencionados.

\subsection{ESTRUCTURA GENERAL DEL DOCUMENTO}

La tesis se organiza en tres partes y seis capítulos. La división en partes obedece a la necesidad de organizar, de manera independiente, los distintos aspectos de la investigación teniendo en cuenta las relaciones temáticas y las facilidades para la lectura.

La primera parte comprende los capítulos $0,1,2$ y 3 . En el capítulo 0 se presentan las pesquisas iniciales. Se comparten las motivaciones investigativas, los antecedentes en los estudios psicolingüísticos, los objetivos generales y específicos, la hipótesis de investigación y la estructura general del documento.

El capítulo 1 se divide en tres. La primera parte se destina a presentar los principales postulados teóricos asociados a la comprensión. Se reflexiona sobre la memoria y el papel de la percepción en el mantenimiento de la información, las inferencias en la comprensión, las claves lingüísticas y las imágenes visuales en el proceso de comprensión textual. La segunda parte ofrece un acercamiento a la 
modificabilidad cognitiva como explicación de la noción de transformación de procesos y el fundamento conceptual-metodológico de la intervención. La tercera parte da cuenta del cuento gráfico desde su definición, historia, estructura, además, de su tipificación como un texto multimodal y verbovisual. Con este capítulo se busca comprender los aspectos teóricos que soportan la investigación.

En el capítulo 2 y 3 se describen los procedimientos seguidos para la planeación y la ejecución de la investigación. En el primero, se comparten las consideraciones metodológicas generales y psicolingüísticas de la investigación; se enuncia el enfoque, la naturaleza, el diseño, los sujetos, las variables, así como las formas como se recolecta la información y los procedimientos para su análisis. En el segundo, se describe el protocolo de intervención en el que se puntualizan las tareas, los materiales y el rol de los participantes.

La segunda parte está conformada por los capítulos 4 y 5 . En el capítulo 4 se socializa el análisis cuantitativo de la información recolectada en el protocolo de intervención y se realiza su respectiva interpretación. Se comparan las proporciones mediante intervalos de confianza entre grupos y tiempos; se da cuenta del desempeño de los sujetos del grupo de estudio y control a través de curvas de aprendizajes grupales e individuales; se realiza el análisis multivariado de correspondencias múltiples, se agrupan los resultados mediante un análisis de clúster para clasificar a los individuos. Lo anterior permite realizar el contraste de la hipótesis y comprobar su fiabilidad.

En el capítulo 5 se comparte el análisis cualitativo de los datos. Para ello se contrastan e interpretan los resultados obtenidos de la intervención. Se describe el 
desempeño de los sujetos en razón a la modificabilidad en la comprensión estimulada gracias al dispositivo diseñado. Se examina el procesamiento rastreado en el comportamiento verbal, se da cuenta de los progresos en la recuperación de información, la producción de inferencias, la reflexión y la evaluación de información. La tercera parte se compone del capítulo 6, las referencias bibliográficas y los anexos. En el capítulo 6 se comparten las conclusiones generales de la investigación, se retoman los hallazgos teóricos y metodológicos a los que se llegan en el transcurso de la investigación.

Las referencias bibliográficas corresponden a todos los textos que han sido citados en el cuerpo de la tesis. Finalmente, los anexos se conforman por distintos productos. En primer lugar, se encuentran los cuestionarios de la prueba pretest, post test y monitoreos. En segundo lugar, el formato de consentimiento informado para proyectos de investigación que diligencia cada uno de los sujetos que participan de la investigación. En tercer lugar, la encuesta diagnóstica para identificar el conocimiento previo de los sujetos respecto al fenómeno objeto de estudio. En cuarto lugar, la base de datos en la que se recogen las respuestas de los sujetos a las diferentes pruebas aplicadas y es el insumo para el análisis estadístico. En quinto lugar, ejemplos de ejercicios cognitivos empleados en la ejecución de la intervención. En sexto lugar, las rejillas para construcción de las pruebas de comprensión, teniendo en cuenta los indicadores de las variables de la investigación. 


\section{CAPÍTULO 1}

\section{RECORRIDOS TEÓRICOS}




\subsection{INTRODUCCIÓN}

En el capítulo 0 se indica que la imagen visual se ha posesionado en los ámbitos discursivos de los sujetos, no obstante, la desatención y la naturalización del análisis conduce a procesos de comprensión y alfabetización poco pertinentes. Desde la psicolingüística se han adelantado estudios direccionados al análisis de la información textual (imagen visual y claves lingüísticas) y su impacto en la compresión, enfocándose en la producción de inferencias y las acciones cognitivas, algunas de ellos se vinculan al género pero partiendo de textos monomodales verbales. En este contexto se formula como objetivo general para la investigación explicar, desde los planteamientos de la psicolingüística, la incidencia de las claves lingüísticas y la imagen visual en la comprensión de textos verbovisuales narrativos como el cuento gráfico.

Para ello, en este capítulo se realiza un recorrido teórico que permitirá interpretar los laberintos metodológicos y los resultados. Se encuentra dividido en cuatro partes. En la primera, se presentan las investigaciones más significativas que sirven de soporte teórico o metodológico a la presente investigación. La segunda, corresponde a la revisión de las cuestiones relacionadas con la comprensión, interesa conocer cómo se visiona desde la psicolingüística, su concepto, su relación con la memoria y la percepción, las inferencias, las claves lingüísticas y la imagen visual. En la tercera, se comparten los aspectos básicos de la modificabilidad cognitiva. En la cuarta, se da cuenta del cuento gráfico, su definición, su historia, su estructura, su caracterización como texto multimodal y verbovisual. 


\subsection{LA COMPRENSIÓN}

Las personas se enfrentan a caudales de información, que procesan de la forma más estratégica para economizar procesos cognitivos y ocupar la memoria con datos absolutamente necesarios. En tal procesamiento, la comprensión permite transformar los textos en unidades de sentido susceptibles de archivarse en la memoria de trabajo o de largo plazo. Desde esta perspectiva, la comprensión es una actividad cognitiva que realizan los sujetos en todo momento, es el resultado de una construcción activa del significado de la información disponible en el texto, que se ve facilitada por el conocimiento previo que el lector posee e integra a la situación comunicativa. El conocimiento del sistema de la lengua influye en la comprensión debido a que las unidades léxicas y su estructuración funcionan como un rompecabezas que el lector debe reconstruir con la ayuda del conocimiento previo, con el objetivo de decodificar los signos convencionales e interpretar las ideas presentadas directamente y las que por sabidas se callan o se muestran indirectamente (León, 2003).

La comprensión lingüística parte del desarrollo de procesos cognitivos. Definidos los últimos como las construcciones mentales reflexivas sobre los mecanismos que implican abordar una tarea, toma de decisión consciente e intencionada; en éstos se interactúa de manera directa con el medio ambiente, facilitando la internalización de la realidad. Al respecto, Lorenzo (2013) plantea que:

[...] la comprensión lectora puede ser conceptualizada como la serie de operaciones que son necesarias para retener información proveniente del texto, en sucesivos ciclos en los que la memoria verbal llega al límite de su capacidad 
de almacenamiento, y debe desalojar vieja información para hacer lugar a la nueva información entrante. (p. 19)

En la comprensión se encuentran procesos cognitivos de bajo y de alto nivel (Valle et al., 1990; De Vega y Cuetos, 1999). Los primeros tienen la función de decodificar el texto, su manejo puede ser más o menos automático y son indispensables para iniciar la comprensión. Este tipo de procesos pueden ejecutarse a pesar de la falta de éxito de los procesos de alto nivel, pero los segundos no pueden realizarse correctamente si los de bajo nivel han sido ejecutados en forma deficiente. Entonces, a mayor automatización de los procesos de bajo nivel, mayores posibilidades de lograr la comprensión profunda de un texto, ya que los recursos atencionales pueden concentrarse en la ejecución de los procesos de alto nivel. Hacen parte de los procesos de bajo nivel:

a. Percepción, todo mensaje antes de ser procesado, se reconoce y se analiza en sus diferentes sentidos. Inicialmente se descifra las formas visuales o letras del sistema ortográfico; se contrasta la información textual con la información almacenada en la memoria a largo plazo (representación abstracta y fundamentalmente de tipo relacional).

b. Reconocimiento de palabras, se averigua a qué concepto se refiere comparando la unidad léxica con el léxico mental (basado en modelos de acceso directo o de búsqueda serial).

c. Codificación sintáctica y procesamiento sintáctico de oraciones, se descubren las correspondientes relaciones estructurales que existen entre las 
palabras. El lector dispone de unas claves sintácticas que le permiten determinar la estructura de las oraciones.

Los procesos de alto nivel tienen la función de transformar el texto para su reestructuración y comprensión. Para lograrlo se activan esquemas de conocimiento previamente adquiridos, el lector integra y elabora el texto, realiza inferencias y predicciones, selecciona la información importante, todo ello en relación con la estructura específica del texto y no en función de palabras u oraciones aisladas, además, apoyado en estrategias de procesamiento. El lector construye una estructura semántica a partir del mensaje presente en la oración y, finalmente, lo integra con sus propios conocimientos. Sólo cuando se ha integrado la información en la memoria se puede decir que ha terminado el proceso de comprensión.

Para Haberlanot (2003) además de las reconstrucciones semánticas realizadas al término de la lectura, comprender implica:

[...] la activación de la información según el lector va procesando las oraciones de un pasaje, la nueva información se integra dentro de la representación ya existente. La información recién leída se enlaza con la información antecedente; esta conexión requiere que la información antecedente esté activa en la memoria de trabajo o que sea reactivada si estuviese inactiva. (p. 72)

En consecuencia, la comprensión implica mecanismos inhibitorios que evitan la saturación de la representación del texto, y mecanismos de activación que permiten establecer, por medio de las inferencias, secuencias semánticas que conducen a la comprensión. 
Teniendo en cuenta que el objetivo de la comprensión es construir una representación mental coherente o estructura de la información que se procesa, se presentan dos tipos de procesos: automáticos y controlados. Los primeros, son inconscientes y remiten a la decodificación de los códigos de la lengua, es decir, están vinculados a la competencia lingüística de los hablantes. Los segundos, dependen de los conocimientos que el sujeto posee, los objetivos de lectura, en otras palabras, el lector ajusta los procesos de comprensión a la tarea específica asignada. Además, se presentan dos mecanismos de control estructural: mecanismos de incremento que permiten aumentar y mantener la activación cuando la información es base para el procesamiento subsecuente, y un mecanismo de supresión que se ocupa de desactivar la información que resulte innecesaria.

Van Dijk y Kintsch (Van Dijk y Kintsch, 1983; Kintsch, 1998) postulan que los sujetos comprenden en ciclos y de forma simultánea, construyen tres niveles de representación durante el proceso: representación superficial, representación del texto base y representación del modelo de situación (Tabla 1). El primero es el nivel de representación más básico de la comprensión; se limita al registro breve de los estímulos gráficos exactos como palabras u oraciones, que se han leído recientemente. La información puede archivarse o no dependiendo si es necesaria para la representación del significado del texto. El segundo, es una reconstrucción semántica más estable de la estructura superficial del texto; es imprescindible para llegar al tercer nivel. El último, es la representación mental final del proceso de comprensión o la comprensión propiamente dicha, refleja el marco de conocimiento del sujeto sobre la 
situación referida por el texto. De esta forma, proporciona los indicadores conceptuales y contextuales para activar información relevante de la memoria a largo plazo.

\section{Tabla 1.}

Síntesis de los niveles de representación durante el proceso de comprensión según Van Dijk y Kintsch.

\begin{tabular}{|c|c|c|}
\hline NIVEL & RESULTADO & PAPEL EN LA COMPRENSIÓN Y MEMORIA \\
\hline $\begin{array}{l}\text { Representación } \\
\text { superficial }\end{array}$ & $\begin{array}{l}\text { Oraciones literalmente } \\
\text { iguales }\end{array}$ & $\begin{array}{l}\text { Función: operaciones de reconocimiento de } \\
\text { palabras necesarias para llevar a cabo } \\
\text { cómputos posteriores. }\end{array}$ \\
\hline $\begin{array}{l}\text { Representación del } \\
\text { texto base }\end{array}$ & $\begin{array}{l}\text { Paráfrasis o frases que } \\
\text { conservan el mismo } \\
\text { significado }\end{array}$ & $\begin{array}{l}\text { Permiten al sujeto conectar ideas de diferente } \\
\text { procedencia del texto. }\end{array}$ \\
\hline $\begin{array}{l}\text { Representación del } \\
\text { modelo de situación }\end{array}$ & $\begin{array}{l}\text { Inferencias y oraciones } \\
\text { nuevas }\end{array}$ & $\begin{array}{l}\text { Resultado mismo de la comprensión y de esta } \\
\text { forma el principal contenido de la memoria } \\
\text { sobre el que deben gravitar las operaciones } \\
\text { destinadas al aprendizaje. }\end{array}$ \\
\hline
\end{tabular}

Fuente: Van Dijk y Kintsch (1983)

El concepto de modelo de situación es esencial puesto que corresponde a "[...] la representación mental de las personas, marco, acciones y sucesos que son mencionados en los textos explícitos" (García Madruga y Fernández,1992, p. 50). Según Van Dijk y Kintsch (1983) los modelos son subjetivos, puesto que representan la experiencia personal y la interpretación del conocimiento que efectúa el participante. También se le conoce como modelo mental, escenarios, representaciones referenciales o representaciones corpóreas. Este tipo de representación se actualiza según las necesidades cognitivas del sujeto y se considera como un estado estable de interpretación de la información que va diseñándose en el curso de la lectura y la comprensión del texto (Figura 1). 


\section{Figura 1}

Modelos mentales en los procesos de comprensión de textos de Van Dijk y Kintsch

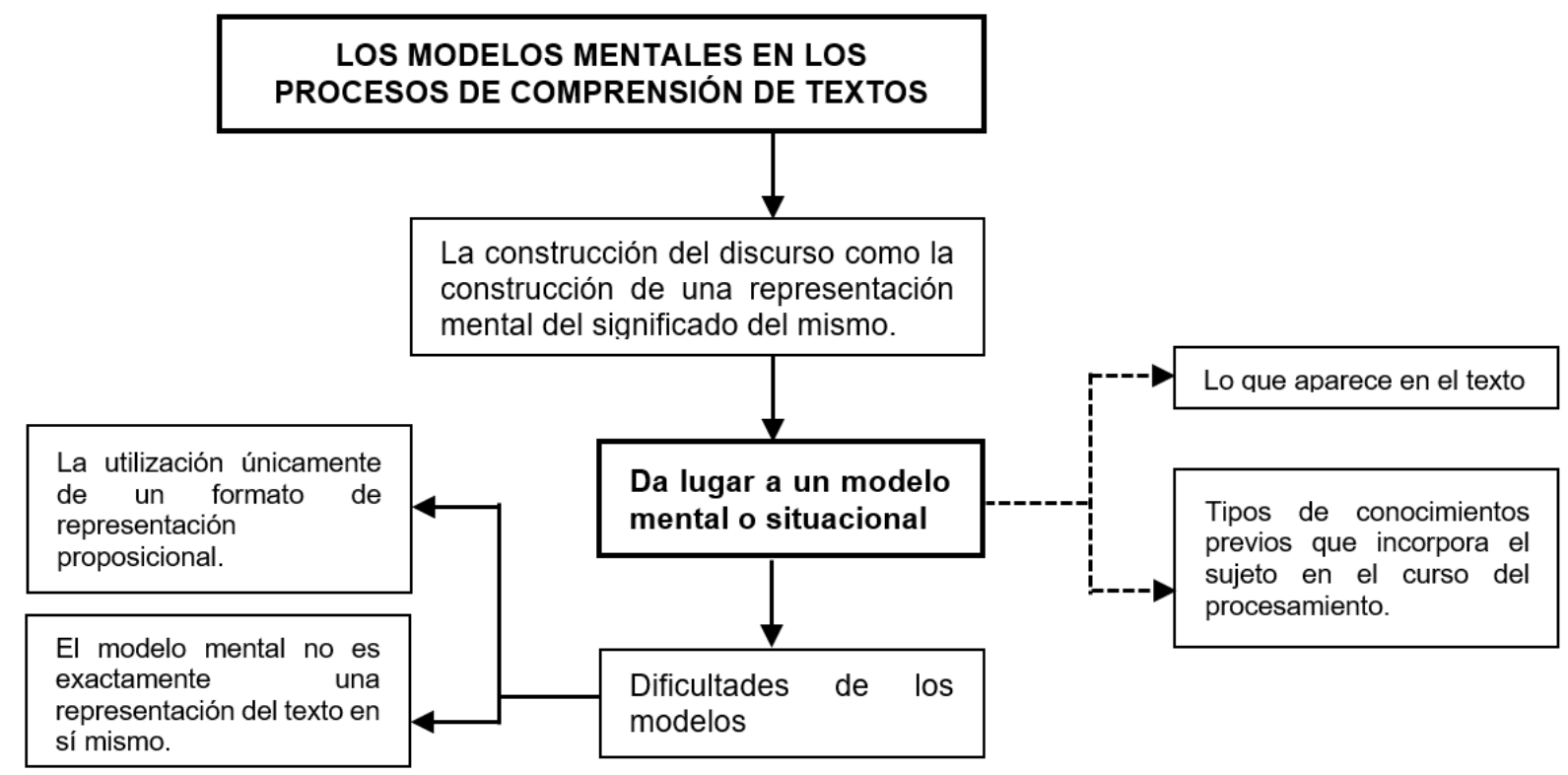

Fuente: Van Dijk y Kintsch,1983.

Diferentes autores (León, 2003) proponen la teoría de los esquemas. Un esquema es una estructura de datos para representar los conceptos genéricos almacenados en la memoria, son dominios de conocimiento que contienen los conocimientos declarativos y su aplicación, proporcionan mapas para obtener nuevas informaciones, dependiendo de los esquemas se activan ciertos tipos de inferencia. Los esquemas adecuados se activan como consecuencia de los procesos de reconocimiento de patrones. Se conciben como procesos activos de abajo-arriba o de entrada de información, y arriba-abajo o el conocimiento conceptual ajustado a los esquemas que han sido activados, que interactúan con el medio y construyen una representación del mismo. En los contenidos de la memoria no se almacenan 
esquemas sino un conjunto de fuerzas de conexión que activadas tiene la capacidad de generar estados que corresponden a esquemas (Figura 2).

\section{Figura 2}

Teoría de los esquemas de Rumelhart

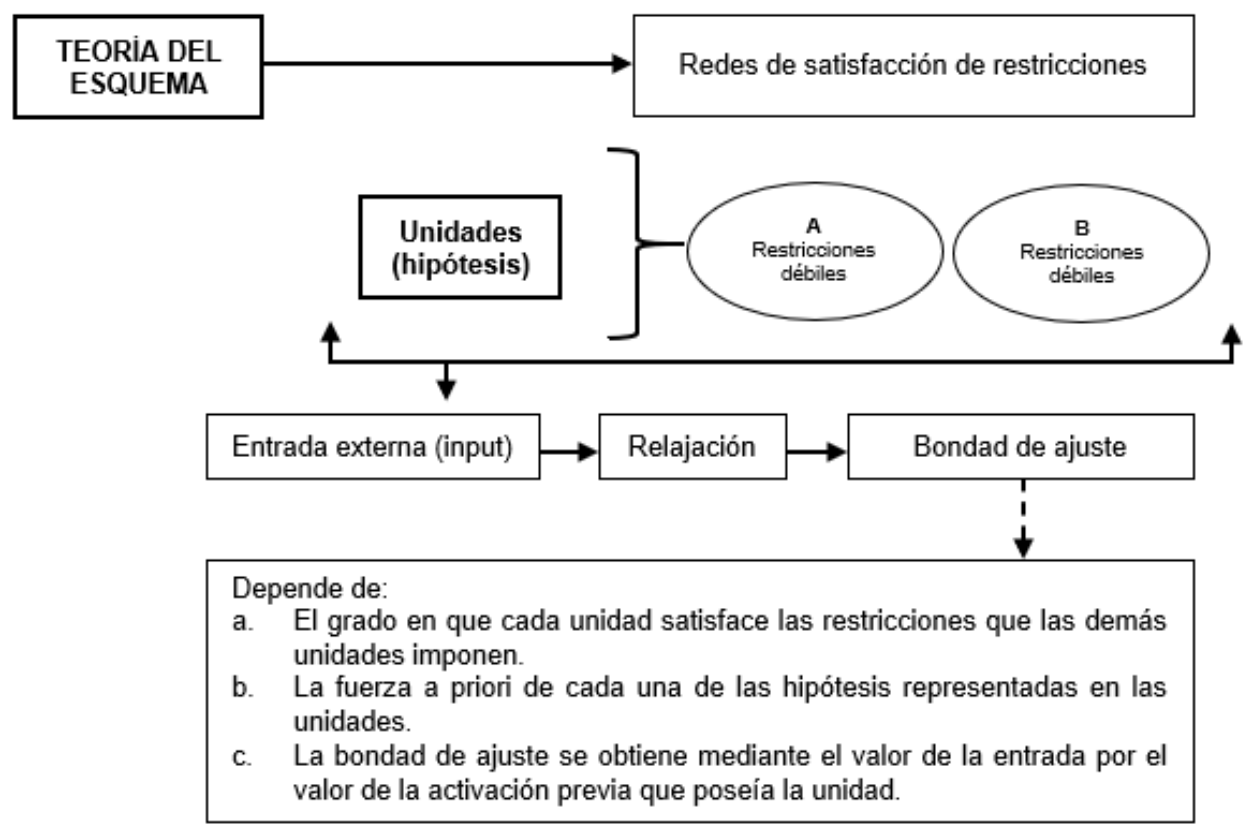

Fuente: León (2003)

Al respecto, León (2003) dice que los esquemas son un procesamiento secuencial y jerárquico de arriba abajo en el que, partiendo de procesos complejos como sugerir una hipótesis, se transita a procesos más específicos (interpretación semántica, análisis sintáctico, decodificación), por tanto, su sentido es descendente de arriba abajo.

Los esquemas cumplen tres funciones en la comprensión: integran proposiciones en unidades coherentes y asimilativas; generan inferencias y expectativas; y controlan según las demandas de la lectura. La comprensión del texto 
resulta de una representación mental (reconstructiva y/o abstractiva) que, a su vez, es escenario o marco de memoria que guía las interpretaciones sucesivas (Pérez, 1994). Hardy y Jackson (2003) afirman que "[...] memoria y comprensión no pueden separarse porque lo que recordamos de la prosa viene determinado en gran medida por cómo lo comprendemos" (p. 226). Por tanto, abordar estudios sobre comprensión implica determinar el rol de la memoria en los procesos de retención, recuperación y reconstrucción. La comprensión lectora irá de lo más simple a lo más complejo, desde el reconocimiento de las letras hasta el procesamiento semántico del texto. Los mecanismos del procesamiento de la información discurrirán de la siguiente forma: letra - fonema - palabra - significado de la palabra - sintáctico - semántico. Para efectos del estudio que se presenta, el interés se centra en la memoria de trabajo que permite mantener la información esencial para la producción de inferencias y, en consecuencia, para la comprensión de textos verbovisuales narrativos.

\subsubsection{La memoria y el papel de la percepción en el mantenimiento de información.}

La memoria es un proceso de representación, almacenamiento y recuperación de información en el cerebro. En las últimas décadas se han propuesto modelos que explican su funcionamiento, para efectos de la investigación se aborda el modelo dual. Según el modelo mencionado la información se procesa gracias a una serie de sistemas de memoria limitada², cada uno de los cuales sirve para una función

\footnotetext{
${ }^{2}$ La memoria capta máximo siete bloques o unidades significativas de información (León, 2003; Valle Arroyo, 1990; De Vega, 1999)
} 
específica y encadenado a los demás módulos. La figura 3 es una reconstrucción del modelo dual de memoria según lo propuesto por Bruning et al. (2005).

\section{Figura 3}

Reconstrucción modelo dual de memoria de Bruning, Norby y Schrau

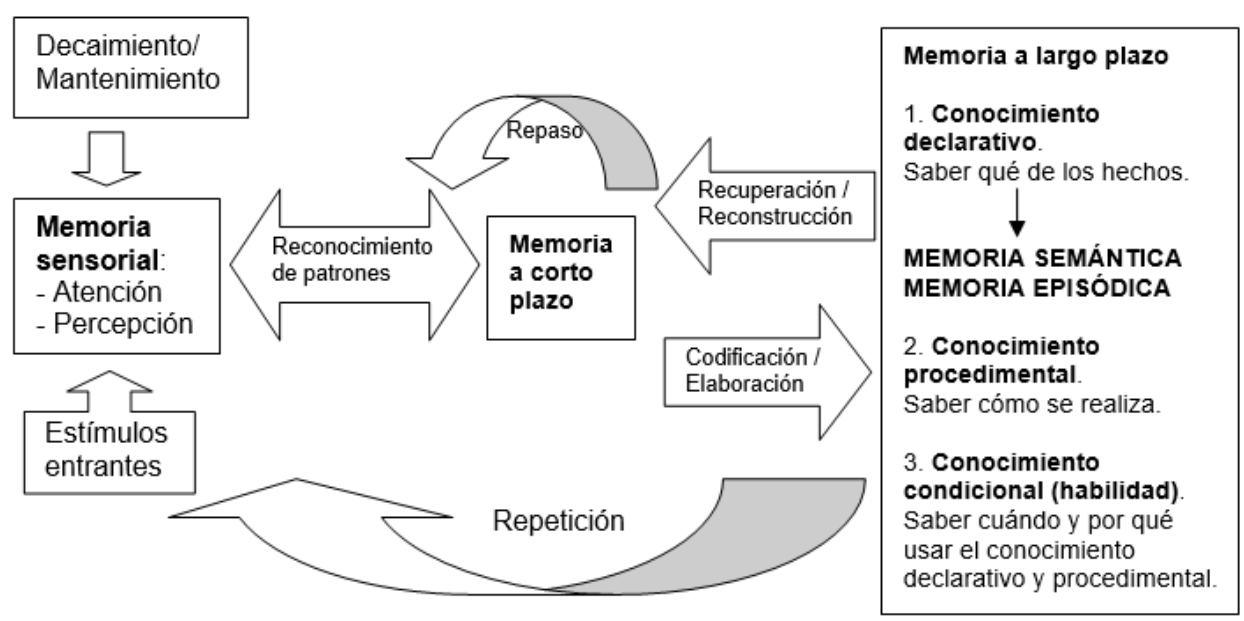

Figura 3. Reconstrucción Modelo Modal de Memoria.

Fuente: Bruning et al. (2005, p.22)

En la memoria sensorial el sujeto percibe la información del entorno originada por estímulos entrantes que desencadenan los procesos de almacenamiento.

Reconoce patrones que asume como ejemplares de los conceptos que organiza en la memoria a largo plazo. Inicialmente, adecúa la plantilla, es decir, guarda el estímulo, accede y compara la información entrante con la poseída, si se ajusta se reconoce. Después se recurre a archivar los prototipos, que no son copias exactas al estímulo sino abstracciones. Por último, se analizan los atributos o las propiedades perceptivas (cualidades) para encontrar ajuste al concepto (Bruning et al., 2005). En esta primera 
parte es trascendental la atención, dado que con ella se focaliza la energía mental y se emplean estrategias de agrupamiento, integración y elaboración.

En la memoria a corto plazo ${ }^{3}$ se añaden significados relevantes según los objetivos del sujeto que almacena para activarlos posteriormente en la memoria a largo plazo; se mantiene la información mientras se realiza la tarea. Este tipo de memoria posee tres componentes primarios que actúan de forma integrada: el ejecutivo central que se encarga de regular el flujo de la información de la memoria a corto plazo a la memoria a largo plazo; el lazo articulatorio que almacena el material en un código verbal de corta duración es importante en el proceso de lectura por la activación de la información de trabajo; y la agenda visual y espacial que archiva el material codificado como imágenes visuales.

Cuando el ejecutivo central cumple su trabajo el original de la información percibida y procesada en la memoria sensorial y a corto plazo se pierde y se guardan bloques informativos significativos. El recuerdo es importante en este proceso, dado que de él depende la comprensión del significado de la información y la capacidad de encontrarla en la memoria a largo plazo. Según Bruning et al. (2005) “[...] el recuerdo se considera una actividad de reconstrucción, en el que los esquemas constituyen el marco que dirige el proceso de recordar" (p. 62). Se diferencian cuatro tipos de recuerdo: reintegración, reproducción, reconocimiento y re-aprendizaje. El primero parte de la reconstrucción de sucesos o hechos sobre la base de estímulos parciales, que pueden ser internos o externos al individuo, tal es el caso de imágenes, palabras o

\footnotetext{
${ }^{3}$ Algunos autores diferencian entre memoria a corto plazo y memoria de trabajo, puesto que afirman que la primera tiene connotación de trabajo cognitivo pasivo y la segunda trabajo cognitivo activo puesto que se piensa y elabora de forma simultánea. Además, recibe otras denominaciones como almacén a corto plazo, memoria operativa, memoria inmediata, memoria activa, memoria primaria (Hardy y Jackson, 2003).
} 
evocaciones. El segundo, es la recuperación activa y sin ayuda de algún elemento de la experiencia pasada, se basa en la memorización. El tercero, apunta a la capacidad de identificar estímulos previamente conocidos. En el último, se memorizan sucesos o hechos por segunda vez, es decir, se recupera y se fija en la memoria nuevamente (Baddeley, 1998; Hardy y Jackson, 2003).

Otro concepto importante en el tránsito de la memoria a corto plazo o de trabajo a la memoria largo plazo es la codificación. La codificación parte de almacenar o saber cómo se guarda la información en la memoria. Una estrategia de codificación elaboradora más sencilla es la mediación, con ésta se relacionan cosas difíciles de recordar con algo más significativo. En la codificación también es necesaria la recuperación que indica cómo se recuerda la información en la memoria, se establece que el recuerdo del conocimiento aumenta cuando las condiciones de la recuperación coinciden con los de codificación, dado que lo contextual ayuda a realizar la búsqueda (Hardy y Jackson, 2003); lo anterior explicaría porque "[...] las personas tienden a reconstruir el significado de una historia cuando recuperan esa información de un depósito de conocimiento general semántico" (Bruning et al., 2005, p. 121).

Para conservar la información los sujetos repiten los datos de forma mental, utilizan de forma directa la información para mantenerla activa en la memoria a corto plazo, pero no dura, posteriormente, elaboran, es decir, relacionan una información con otra información, exige el recuerdo a largo plazo (Bruning et al., 2005). Los procesos que se dan en la memoria dependen de las entradas y las salidas de la información, que el cerebro considere relevante para así procesarla, codificarla, y si se pierde, 
recuperarla. En este sentido, Atkinson y Shiffrin proponen un modelo de procesamiento de información tal como se muestra en la figura 4.

\section{Figura 4}

Modelo de procesamiento de la información de Atkinson y Shiffrin

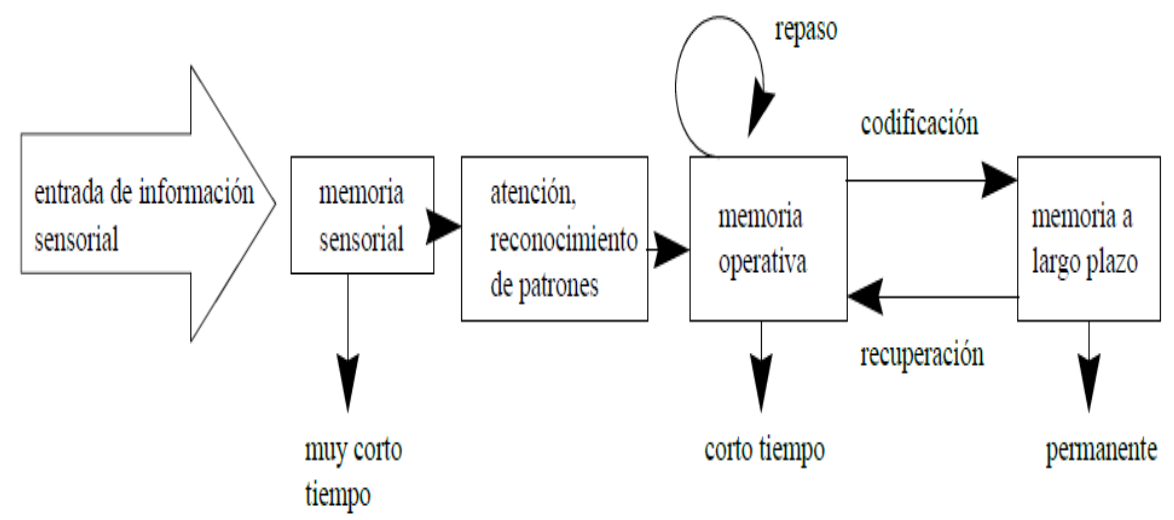

Fuente: Atkinson y Shiffrin (1968)

Debido a la capacidad limitada de la memoria sensorial y la memoria de trabajo se presenta el decaimiento. Hardy y Jackson (2003) afirman que, si atiende una información y no se procesa de alguna manera, ésta decae en los próximos 15 a 30 segundos, así se libera la mente del exceso de información. Una estrategia para evitar el decaimiento es el repaso, es decir, la activación transitoria o el reciclaje de la información por el lazo articulatorio; así, se mantienen los primeros elementos codificados porque poseen más tiempo de repaso o los últimos puesto que carecen de tiempo para decaer y se presenta la recencia de la información.

Teniendo en cuenta la complejidad de la mente y que "[...] Los procesos automáticos no precisan mucha atención y pueden ejecutarse en paralelo con otras actividades cognoscitivas" (Hardy y Jackson, 2003, p. 119), es importante considerar 
que, según el modelo dual de memoria, la información no necesariamente debe pasar por un módulo a la vez, puesto que la información que recibe la memoria a largo plazo puede analizarse, reajustarse y establecer conexiones de forma alterna en la memoria a corto plazo y memoria a largo plazo, consiguiendo resultados parciales y totales.

Lorenzo (2013), expone la conexión de los conceptos presentados en la estructura de la recuperación y el papel de la memoria (Figura 5)

\section{Figura 5}

Estructura de recuperación

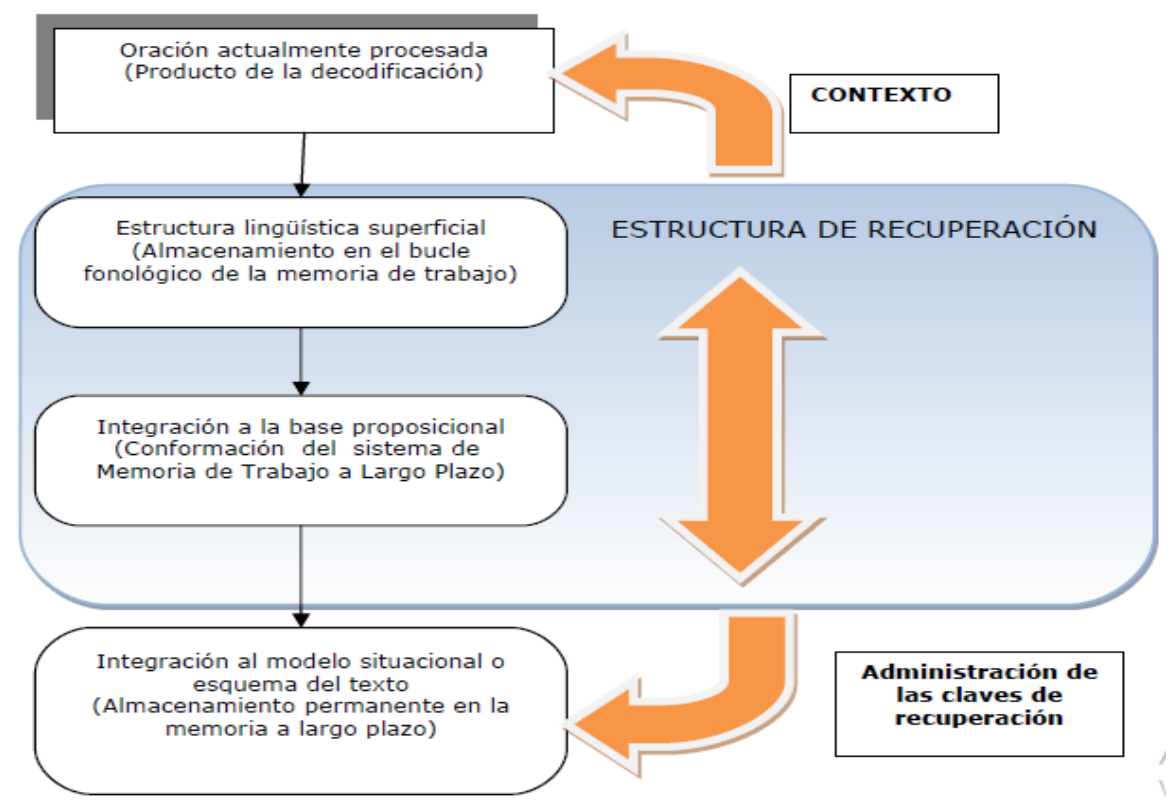

Fuente: Lorenzo (2013)

Finalmente, emprender estudios sobre la comprensión implica entenderla como una actividad cognitiva que involucra procesos de decodificación de los niveles de la lengua e imágenes visuales, que conducen a activar y procesar información textual y previa encadenada a esquemas, cuyo procesamiento necesita la intervención de 
sistemas de memoria limitada: la memoria sensorial para almacenar los estímulos esenciales discriminados por la atención y la percepción, susceptibles de utilizarse posteriormente; la memoria de trabajo para seleccionar y guardar la información fundamental según los objetivos del lector; y la memoria a largo plazo para archivar la información permanente. En este sentido el estudio de la memoria no es un fin en sí mismo, si no un medio para abordar la producción de inferencias y la comprensión de textos, que tiene efectos desencadenantes y de evocación de recuerdos, conocimientos y experiencias anteriores, además, de la recencia de información (Sáiz et al., 1999).

\subsubsection{Las inferencias}

La comprensión es efectiva gracias a los procesos inferenciales. En éstos se realizan subprocesos de ajuste entre lo dicho y lo no dicho, el fragmento de lengua y la competencia lingüística, la información textual, la competencia comunicativa y la pragmática, relaciones imposibles sin la intervención de inferencias de múltiples tipos. Lo expuesto corrobora que sin inferencias no hay compresión, éstas son la base para el desciframiento de los códigos escritos u orales y la integración de la información textual con el conocimiento previo.

León (2003) define las inferencias como "[...] las representaciones mentales específicas que construimos cuando tratamos de comprender algo, sustituyéndolo, añadiendo, integrando u omitiendo información de la fuente original" (p. 23). Por su parte, Salas (2012) afirma que: 
[...] es un proceso cognitivo a través del cual un sujeto obtiene información nueva a partir de la información ya disponible. El lector entra en interacción con el texto a partir de ciertos elementos de éste, pero también de su conocimiento previo, es decir que el lector podrá hacer inferencias debido a los conocimientos que ya posee y a la profundidad que logre en su lectura (p. 51).

Entonces, las inferencias se constituyen en el proceso de razonamiento en el que se deduce de lo explícito lo que se dice de modo implícito. Por lo tanto, la inferencia lleva a la implicatura, esto es, a los significados tácitos semánticos y pragmáticos. Los primeros, corresponden a informaciones que pueden deducirse de un enunciado. Los segundos, remiten a la información no dicha, pero que se comunica y que puede deducirse por el contexto, bien sea situacional o cultural; activando el conocimiento del mundo almacenado en los marcos de conocimiento y de referencia (Molinari Maroto, 1996).

Las inferencias son imprescindibles en cualquier intercambio comunicativo porque permiten identificar, analizar y almacenar la información en la memoria de forma óptima. Implican procesos cognitivos en los que se discrimina información local para llegar a la comprensión del discurso, facilitando la conservación de la información que se considera de uso probable en la inmediatez o en la posteridad, se transforman y reconstruyen representaciones mentales a partir de la información disponible. A su vez hacen presencia estrategias cognitivas o procedimientos y secuencias estructuradas que permiten resolver problemas, tomar decisiones o acceder a recuerdos e información considerada especialmente importante, es decir, intervienen una serie de conocimientos y habilidades que el lector puede emplear para adquirir, retener, integrar 
y recuperar información (López et al., 1989). El lector, gracias a estas estrategias puede elegir adecuadamente la información que entra en la memoria de trabajo para no provocar sobrecargas que pueden generar una mala comprensión de lo leído. Así, el éxito del proceso de comprensión depende de las estrategias de selección usadas para determinar cuáles proposiciones serán transferidas a la memoria a largo plazo.

Las estrategias cognitivas empleadas en la producción de inferencias pueden clasificarse en dos grandes tipos. Las selectivas, cuyo fin es realizar una lectura superficial del texto, en la que se incluyen la lectura rápida, la lectura para atender aspectos de la información o para identificar el significado de palabras. Las generativas o de elaboración, cuyo propósito es el procesamiento profundo de la información. En este último grupo de estrategias se incluyen todas aquellas que permiten hacer algo, realizar cierto tipo de construcción con la información que se lee: elaborar una imagen mental, hacer una analogía o un esquema integrador, resumir información, parafrasear, subrayar, discriminar, jerarquizar, comparar-contrastar, proyectar, recuperar, evocar, transferir, construir, predecir (McKoon y Ratcliff, 1992). Al respecto, León (2003) expresa que las inferencias funcionan por lo menos de tres maneras: conectando unos sucesos con otros dentro de una historia particular, completando los espacios vacíos o "lagunas" del texto y construyéndole al texto una porción agregada de sentido proveniente de su conexión con las circunstancias específicas del contexto y con los esquemas del lector.

Con la intervención de las estrategias cognitivas mencionadas, las inferencias se organizan en procesos integrantes de tres niveles de representación ${ }^{4}$. El primero,

${ }^{4}$ Desde la teoría interactiva (Mac Donald et al., 1994; Farah y Mcclelland, 1992) se reconoce la colaboración entre los procesos integrantes, por tanto, se acepta que el lector utiliza todas las fuentes de 
corresponde a la palabra que se codifica en los caracteres visuales y se accede al léxico recuperando el significado de las unidades léxicas archivadas en la memoria. El segundo, tiene que ver con las oraciones, que incluye subprocesos sintácticos en los que se determina el tipo de palabra, su posición y la influencia de los signos de puntuación, en otras palabras, se organizan las palabras dentro de la estructura sintáctica de las oraciones. El tercero, se enfoca hacia el texto y los nexos que se establecen entre oración y textos ya leídos, en esta parte es donde realmente las inferencias se constituyen como estrategias de comprensión. Por consiguiente, se presentan representaciones relativamente efímeras, como la de los rasgos superficiales y la información semántica de oraciones y textos, base para las representaciones duraderas como la del modelo de situación del texto.

Las inferencias cumplen tres funciones. La cognitiva consiste en intervenir en la superficie de los datos, procesarlos e integrarlos a las representaciones mentales. La comunicativa, implica la facilidad en la transmisión de información de un modo económico, atractivo, sin sobrecarga de almacenamiento transitorio y ajustado a la relación emisor-receptor. Y la conductual, apunta a dirigir y predecir las conductas, optimizar beneficios y minimizar daños (Gutiérrez-Calvo, 2003). Tales funciones anclan los procesos inferenciales a la adaptación del texto que se procesa y a los otros sujetos que pueden intervenir en los mismos.

Según Belinchón, Riviére e Igoa (1992), en un texto se pueden inferir intenciones comunicativas a partir del procesamiento de lo dicho, de los conocimientos compartidos y organizados en esquemas del lenguaje mismo, de las propiedades esenciales de los 1983) postulan que tales procesos son independientes, así la información sintáctica y la semántica se procesan por separado (Haberlanot, 2003) 
mundos intencionales interiores, de las relaciones generales con el mundo. Tales esquemas de conocimiento proporcionan un andamiaje mental, favorecen la elaboración de la información y su búsqueda ordenada en la memoria, facilitan el resumen y la reconstrucción del contenido y mensaje de los textos. Actividades fundamentalmente constructivas que se operan de diversos modos: relacionando, produciendo, transformando y generando información.

Ahora bien, si la información textual -sea claves lingüísticas o imágenes visuales-funciona como instrucción de procesamiento, los marcos de conocimiento y referencia remiten a la información adquirida que el sujeto puede activar para generar respuestas rápidas y apropiadas. Tales marcos sirven para extraer significados, conferir de coherencia a lo leído, determinar focos discursivos, generar niveles de representación, extraer información implícita de lo explícito, pronosticar ideas y activar procesos de recuperación. En otras palabras, el conocimiento poseído por los sujetos se erige como vínculo entre el texto y la realidad pragmática del mismo. No obstante, los modelos de comprensión o teorías sobre las inferencias no hacen mención explícita del papel que juega en la generación de inferencias o si lo hacen lo reducen a una red de conceptos o conocimientos fácilmente accesibles. Los modelos presentados en los últimos años (Graesser et al., 1994; McKoon y Ratcliff, 1992; Schmalhofer et al., 2002) apuntan a que el nivel de conocimiento previo y el grado de pericia ${ }^{5}$ con el que se usa puede acelerar la producción de inferencias, específicamente elaborativas (León, 2003).

\footnotetext{
5 Según León (2003, p. 62) la pericia es un concepto cognitivo referido a la acción efectiva del conocimiento. Implica que, dependiendo si se es novato o experto en cierta área del conocimiento, se resuelven las dificultades de una forma o de otra, se activa mayor cantidad de conocimiento previo, se opta por la organización apropiada, se manifiesta habilidades creativas y analíticas superiores, se presenta mayor o menor grado de automatización, entre otras.
} 
En cuanto a la clasificación de las inferencias, las investigaciones psicolingüísticas (De Vega, 1990; De Vega y Cuetos, 1999) de las últimas décadas han participado en este debate desde las teorías minimalistas y constructivistas. Las primeras, "[...] se ocupan exclusivamente de las inferencias [on line] que se producen automáticamente durante la lectura", "se basan en la información fácilmente disponible, en frases explícitas del texto, o en aquellas que se precisan para conseguir la coherencia local". Las segundas, "explican las inferencias [off-line] que los sujetos generan cuando construyen un modelo de la situación sobre el que trata el texto" (McKoon y Ratcliff, 1992; García Madruga, 1992). Cada aparte de un texto exige inferencias on-line u off-line dependiendo de las relaciones semánticas implícitas o de la forma de presentar la información, su activación está sujeta al contexto en el que se producen, la disposición y el acceso al conocimiento del sujeto que comprende.

Partiendo de las teorías mencionadas, las inferencias pueden clasificarse según su contenido, su función, su forma lógica y su dirección. Vonk y Noordman (1990), Graesser y Bertus (1998), Graesser y Bower (1990), Graesser y Kreuz (1993) proponen taxonomías en las que se reconoce la importancia de la información textual. Los primeros, identifican las inferencias deducidas o autorizadas por el texto (presuposiciones, vinculaciones, implicaciones) y las que contribuyen a la coherencia local (anáforas y relaciones causales) como obligatorias; las inferencias producto de las deducciones autorizadas o no por el texto (pragmáticas) y las que contribuyen a la elaboración de las representaciones como elaboraciones. Los autores nombrados, desde una posición constructivista, categorizan las inferencias en on-line y off-line. Entonces, se entiende la comprensión como una reconstrucción de sentidos y 
representaciones, que parte del surgimiento de inferencias en las que la información textual propicia la activación de conocimientos previos, ya sea durante o posterior a la lectura. Trabasso y Magliano (1996) afirman que en las inferencias se activan los conocimientos generales del mundo, produciéndose inferencias asociativas; se mantiene informaciones en la memoria de trabajo $u$ oraciones sucesivas, propiciándose inferencias explicativas; y se recupera información desde la representación del texto en la memoria a largo plazo, presentándose inferencias predictivas.

La mente es "una máquina de hacer inferencias" $y^{y}$ las inferencias son tareas de orden superior. El conocimiento disponible del sujeto y su relación con lo que lee es el motor que induce a la generación de inferencias; se parte de unos contenidos descritos en el texto, el lector elabora un conjunto de proposiciones inferidas y, al mismo tiempo, construye un modelo de situación a partir de las ideas o proposiciones disponibles; “[...] el significado se construye sobre la base del conocimiento previo y en el contexto que tiene luego la tarea" (Bruning et al.,2005, p. 23). Entonces, la comprensión y la producción de inferencias se erigen como actividades cognitivas particulares que se ven afectadas por la organización de la información del texto, el contexto en el cual se produce, el género discurso en el que se incluye y el acervo de conocimientos de los sujetos.

\subsubsection{Las claves lingüísticas}

El proceso de comprensión textual se inicia cuando el lector es capaz de crear relaciones semánticas a partir de los elementos del texto, por tanto, la tarea de elaborar

\footnotetext{
${ }^{6}$ Metáfora utilizada por Jerome Bruner y retomada por León (2003). Se refiere a concebir a la mente en su capacidad para activar, almacenar y utilizar información vieja para interpretar información de entrada.
} 
el significado de este exige al sujeto poner en funcionamiento operaciones cognitivas que posibilitan el procesamiento de la información y que se dan de manera casi automática.

Tapia (2005) expone que algunos de los procesos psicológicos implicados en la lectura y la comprensión de los textos son la identificación del significado de la palabra y el análisis de las relaciones semánticas. Estos dos procesos psicológicos dependen de varios factores, por ejemplo, de la disposición léxica del sujeto y de las claves lingüísticas que proporcione el contenido del texto. El primero, está relacionado con los conocimientos previos y los marcos de referencia que el lector posee anteriores al ejercicio de la lectura; el segundo, se basa en las marcas discursivas que el autor proporciona al lector para que éste a su vez logre construir la interpretación del texto.

El reconocimiento adecuado del léxico, las proposiciones o los fragmentos discursivos, que en resumen constituyen las claves lingüísticas, son decodificadas con el apoyo consecutivo de la memoria sensorial y la de trabajo, dando lugar a la elaboración de esquemas y así a la activación anticipada de inferencias (automáticas o de puente) como lo sustenta Tapia (2005).

Kintsch (1998) establece la premisa de que el proceso de comprensión lectora se desarrolla a partir de ciclos, basados en el reconocimiento y el análisis de estructuras proposicionales y que se relacionan de manera coherente. Así, se recuperaría una parte de la información de entrada y otra se perdería; es decir, la permanencia de la información depende del grado de activación de la información de entrada y el nexo que establezca con la información depositada en la memoria de a largo plazo. En suma, las unidades lingüísticas que participan como claves lingüísticas 
dentro del texto, se constituyen en elementos imprescindibles para el surgimiento de estructuras discursivas portadoras de significado, que permiten la conexión de la nueva información con la depositada en la memoria de largo plazo, dando lugar a la producción de inferencias automáticas y de puentes, que se consolidan como una primera tarea del proceso de comprensión.

Goodman (1998) afirma que "los sujetos desarrollan estrategias de muestreo para seleccionar sólo claves más útiles y necesarias" (p.100), de esta manera cuando el lector reconoce con destreza las claves lingüísticas que proporciona el texto es capaz de elaborar su significado, es decir, se consolida como una herramienta discursiva que agiliza los procesos cognitivos vinculados al procesamiento de la información y a la elaboración de inferencias de puente supeditadas a la memoria sensorial, de trabajo y de a largo plazo.

Por otra parte, es necesario aclarar que las claves lingüísticas no operan por sí solas, éstas deben estar relacionadas con el género discursivo y los demás componentes textuales como: esquemas, gráficos, tablas, figuras, etc., y de esta manera no figurarían como elementos aislados cuando el lector empiece a conectar la información de entrada (input) con la ya existente (conocimientos previos) y no se verá interferida la de salida (output), garantizando así que la elaboración de inferencias será más confiables y, por tanto, el proceso de comprensión alcanzado resultaría el esperado. 


\subsubsection{La imagen visual}

Acaso (2009) indica que la comunicación visual corresponde al sistema de transmisión de señales cuyo código es el lenguaje visual y este a su vez es el código específico de la comunicación visual, es decir, un sistema en el cual se enuncia y se recibe información a través del sentido de la vista. Los seres humanos no estudian ni la morfología, ni la sintaxis del lenguaje visual, sin embargo, saben leerlo; lo expresado se debe a que desde niños lo aprenden de forma automática, aunque superficial, gracias a su inmediatez, permanente estimulación y cercanía a la realidad o como lo denomina Roland Barthes (1986) el efecto realidad. La comunicación visual es el sistema de semiestructurado más antiguo que se conoce y se caracteriza por su facilidad de penetración, es decir, que cuesta menos leerlo y tiene un carácter relativamente más universal. Ahora bien, una imagen, entendida esta como una unidad de representación visual, no es la realidad, sino que se parece o aproxima. Dentro del campo semiológico representar consiste en sustituir la realidad a través del lenguaje visual. El signo es cualquier cosa que represente a otra y el signo visual es cualquier cosa que represente a otra a través del lenguaje visual.

Las imágenes fijas visuales han sido caracterizadas en gran medida por la semiótica dada su naturaleza simbólica. Las imágenes sirven primero, esencialmente, como símbolos, símbolos religiosos, que, se suponía, daban acceso a la esfera de lo sagrado mediante la manifestación más o menos directa de una presencia divina. Los simbolismos no son solamente religiosos, y la función simbólica de las imágenes ha sobrevivido ampliamente a la laicización (Aumont, 1992). 
Ferradini y Tedesco (1997) afirman que la imagen es representacional, intencionalidad, construcción y expresión, en la medida que se presenta de determinada forma, puede ser modificada y puede comunicar. Por su parte, Villafañe (2006) expone que las imágenes son signos que tienen dos características la icónica y la plástica; la primera, hace referencia a la similitud del signo con la realidad que representa y la segunda, a los rasgos que distinguen un signo en particular de otro, es decir los rasgos propios de cada signo. Éstas sustituyen las características concretas de un referente y se acomodan a los contextos y las necesidades comunicativas establecidas por las comunidades. La imagen visual, especialmente la fija, ha adquirido un papel protagónico en la sociedad de consumo y en los contextos académicos. Lo anterior, ha propiciado el surgimiento de estudios que buscan caracterizarla formalmente, rastrear su alto nivel de iconicidad, los aportes que da a la comprensión de la realidad y su interacción con los receptores de los mensajes.

La imagen es un texto icónico debido a su carácter representativo y expresivo. Su composición le permite ser parte de distintos contextos comunicativos; a partir de ella se representan situaciones simples que algunos autores han denominado monosémicas, que constituyen mensajes someros y no exigen al lector procesos complejos de interpretación, también se han considerado las representaciones polisémicas que se basan en situaciones mucho más elaboradas y exigen al lector producir un determinado número de inferencias, porque adquieren carácter connotativo en la medida en que se relacionen los elementos que la componen (Acaso, 2009).

Retomando el nivel de iconicidad de la imagen como una de sus características formales se tiene que la polisemia icónica es calculada y programada por los creadores 
de las imágenes para entrar en conexión con los sentimientos, creencias y tendencias arraigadas al público al que va destinado el mensaje. Se contempla un mensaje y se responde a él con mayor intensidad cuanto mayor es el ajuste de sus propuestas a la satisfacción aparente de necesidades humanas básicas.

Las características formales de cualquier tipo de imagen visual fija son el tamaño, el formato, el nivel de iconicidad, la simplicidad o la complejidad. El tamaño se relaciona con la dimensión o proporción de los objetos que componen la imagen, se distinguen: los tamaños grandes, medianos, pequeños, miniatura; resulta útil para destacar la importancia y el lugar que ocupa una imagen en el espacio y también agiliza el proceso percepción y atención del sujeto al momento de construir el significado de esta. El formato corresponde a la manera en que se encuentran distribuidos los elementos, el más típico es el rectangular y se divide en: vertical y horizontal; sin embargo, existen poligonales, circulares, mixtos e irregulares; por otra parte, se distinguen el formato largo, que viabiliza secuencias visuales complejas y narrativas, y el formato corto, adecua los elementos para situaciones más espontáneas y descriptivas. El nivel de iconicidad determina la similitud de la imagen con la realidad, es decir, es la representación más objetiva de la realidad que puede representarse a partir de un signo; por ello se asume que, el nivel de iconicidad facilita el procesamiento de la información. La simplicidad o la complejidad dependen de la cantidad de elementos que componen a la imagen, no sólo se sustentan por la cantidad de información visual, sino por el carácter monosémico o polisémico de sus elementos, lo que en consecuencia determina el proceso de percepción y procesamiento de la imagen (Groupe $\mu, 1993)$. 
La imagen visual representa escenas, perfiles y otros elementos que, a consideración de su autor, logren configurar una idea. Para analizarla es conveniente tener en cuenta:

$>$ El punto: este elemento determina el enfoque visual del observador, es decir, genera los focos de interés en el momento en que se está llevando a cabo su lectura.

La línea: se convierte en un foco visual para el observador. Villafañe (2006) sustenta que las líneas pueden ser: estructurales si organizan los elementos de la imagen, o formales si concretan la forma, el fondo o la profundidad.

La textura: da cuenta de las características de la superficie de los elementos que componen la imagen, así, la textura aporta al proceso de percepción visual, determina la naturaleza del objeto que representa.

La luz: hace posible el proceso de percepción. El ojo ve las formas por la presencia de la luz, ésta le otorga a la imagen propiedades estéticas y expresivas. El grado de luminosidad define tonos, matices, sombras, etc., aporta efectos que son determinantes en el proceso de comprensión. Gómez Nava (2015) plantea que las variaciones tonales son elementos muy importantes en la interpretación, constituyendo uno de los principales criterios de interpretación visual. La expresión tonal de los objetos en la imagen está directamente relacionada con la cantidad de energía reflejada por la superficie.

El color: es una característica que le otorga a la imagen, propiedades estéticas y plásticas, que la acercan a la realidad y facilitan su proceso de comprensión. Los colores se dividen en cálidos y fríos, claros u oscuros. La ventaja del color 
sobre el tono es que el ojo humano es mucho más sensible a las variaciones cromáticas frente a las variaciones de intensidad luminosa. Además, debido a la posibilidad de mezclar varias bandas del espectro en una composición de color, éste resulta ser un elemento básico para la interpretación visual de las imágenes. (Gómez, 2015).

D El encuadre: define la lejanía o la cercanía de la imagen respecto al ojo del observador, se apoya en el plano que es el recurso que permite que la imagen ocupe un determinado espacio y se enfoque desde un sitio en especial. Se pueden identificar varios tipos de planos: primer plano, plano detalle, primerísimo primer plano, plano medio, plano americano, plano general, plano conjunto, etc., éstos ayudan a construir las relaciones significativas entre los elementos de la imagen.

La angulación: es la posición desde la cual se enfoca la imagen. Existen distintos tipos de angulación: normal, picado, contrapicado, inclinado e imposible.

La composición de la imagen: es la manera como se distribuyen y relacionan entre sí los elementos que la componen y resultan significativos en la reconstrucción global de su significado. En literatura relacionada se indica que existen algunos principios bajo los cuales se establece la composición de una imagen visual algunos de ellos son: la claridad, la simplicidad, la armonía, el contraste, el equilibrio y el ritmo. Cuando el sujeto es capaz de reconocer estos el proceso de comprensión es mucho más objetivo. 
El peso visual: la imagen contiene elementos que generan en el observador sugestión, por convención éstos están ubicados estratégicamente y los complementan el tamaño, el color, el tratamiento superficial (textura) y el aislamiento (a mayor distancia mayor el peso visual).

Direcciones visuales: dependen directamente de la composición de la imagen y la distribución de los elementos, consisten en determinar en qué dirección el ojo percibe la información visual, es decir, la dirección visual sirve de apoyo al proceso de percepción y a la memoria sensorial.

Tapia (2005) sostiene que la imagen visual fija se interpreta a partir de códigos y los clasificó de la siguiente manera:

> Código perceptivo: corresponde al conjunto de características formales de la imagen como el punto, la forma, el fondo, etc., que son captadas por la visión y, por tanto, que intervienen en la percepción.

> Código cromático: es la distribución de colores que caracterizan a la imagen y que le otorgan una carga semántica. Así, se configura como un elemento que proporciona datos al proceso de comprensión de los textos visuales.

Código espacial: está dado por el campo visual, se basa en los planos de visión, el encuadre, la inclinación y otros elementos de los que dependen la extensión escenográfica, lo que cobra importancia al momento de reconstruir la secuencia axiológica de la historia.

> Código morfosintáctico: elementos que permiten la reconstrucción de la imagen y, por tanto, la de su mensaje, es decir, involucra todas las características formales de la misma. 
Código gestual: conjunto de gestos, posiciones y expresiones que muestran los personajes que constituyen la imagen. Este clasifica los perfiles de los personajes en los textos visuales y en otros como el cuento gráfico.

$>$ Código retórico: constituye el conjunto de recursos estilísticos que se transponen en la imagen visual, como: metáforas, sinécdoques, hipérboles, etc.

$>$ Código simbólico: es de carácter semiótico, lo conforman la serie de signos que se les otorga un significado sociocultural, entre ellos: las banderas, los escudos y estandartes que representan a distintos grupos sociales. De allí, que resulten útiles para llevar a cabo la reconstrucción semántica del código visual. Villafañe (2006) sustenta que en la imagen visual la temporalidad se presenta de tres maneras:

Simultaneidad: la imagen puede ser percibida desde un solo punto de vista (un cuadro)

Sucesividad: la imagen no se puede ver desde un único punto de vista, hay que moverse a diferentes puntos (revista, cómic).

Secuencialidad: la imagen está presente con el tiempo de duración para ser vista. Este es el caso del cine (imagen secuencial en movimiento). También conocido como tiempo de proyección.

Steiner (2012) sustenta que las imágenes visuales tienen tres niveles de interpretación, lo que permite que se pueda inferir lo que el autor quiera decir, los define así:

Descripción pre-iconográfica o significado natural. En este nivel se procede a la identificación de objetos (árboles, edificios, animales y personajes) y 
situaciones (banquetes, batallas, etc.) que aparecen representadas. Se describe lo que perciben los sentidos, formas, colores, masas, etc. de acuerdo con la experiencia.

Análisis iconográfico en sentido estricto. En el segundo nivel la forma pasa a ser una imagen que el intérprete explica y clasifica dentro de una cultura determinada. En este nivel se utilizan los conocimientos y el pensamiento asociativo para comprender lo que los sentidos han captado, se accede así al significado convencional de las cosas; esto es, al significado por todos conocido y aceptado como válido. Esto implica tener un conocimiento amplio de la cultura en la cual se origina el fenómeno o situación que se quiere entender.

Interpretación iconológica. El intérprete es quien debe descubrir significados ocultos que están en lo más profundo del inconsciente individual o colectivo. Este es el nivel del significado intrínseco, de los principios subyacentes que revelan el carácter de una nación, una época, una clase social, una creencia religiosa, de una mentalidad. Aquí las imágenes proporcionan a los historiadores de la cultura un testimonio muy útil.

Acaso (2009) indica que es el punctum el elemento que le permite al espectador aportar significados a la imagen. Barthes (1986) lo divide en tres: punctum principal, que favorece el paso del discurso denotativo al connotativo; el punctum secundario, que son elementos que acompañan al principal y el contapunctum, es el contra peso del punctum. Es muy importante tener presente que la interpretación de una imagen está determinada, de una u otra manera, por el contexto, específicamente el tiempo y el lugar. Esto, a su vez, permite que haya una multiplicidad de significaciones posibles. 
Comprenderla, entonces, consiste en determinar qué quiere decir la imagen para el lector y no qué quiso decir el autor.

\subsubsection{El procesamiento de claves lingüísticas}

La percepción, sea de las claves lingüísticas o las imágenes visuales, corresponde al proceso psicológico de la interpretación significativa, al conocimiento de las cosas y los hechos del mundo exterior transmitida por medio de los sentidos, resultado de un estímulo o impresión luminosa registrada por los ojos. La lectura empieza con una fijación del ojo en el estímulo visual que dura segundos y abarca aproximadamente de 15 a 20 letras. El patrón visual que resulta se refleja en la retina gracias a la actividad neurológica de la corteza cerebral; es así como se forma un icono que viene a ser como una imagen visual no identificada (serie de barras, líneas, curvas, ángulos, espacios, aberturas, etc.). La imagen icónica del input visual se mantiene durante un periodo muy breve (fracciones de segundo) en la retina, aun cuando el estímulo visual haya desaparecido (Alberich et al., s.f.).

El acto perceptivo se realiza con automatismo y tiene múltiples implicaciones, pues es evidente que el mundo real no es lo que percibimos por la visión y, por ello, se precisa de una interpretación constante y convincente de las señales recibidas. Fisiológicamente los hombres comparten el acto óptico-visual mecánico, pero se registran divergencias en cuanto a cultura, educación, edad, memoria, estilo cognitivo y estado emocional. Para los psicólogos de la Gestalt la percepción es provocada por excitación espontánea del sistema nervioso central. Independientemente de lo innato o empírico que sea la percepción demanda un proceso instruccional y su falencia 
ocasiona dificultades en el procesamiento textual. Salas (2012) plantea que la lectura es un proceso complejo y coordinado que incluye operaciones preceptuales, regulares, lingüísticas y conceptuales, y los lectores a su vez también representan los conceptos y los hechos que se describen en el texto. El lenguaje escrito está compuesto por signos que son imágenes reducidas a una convención, en este caso el de ser letras, eslabones para construir signos más complejos, las palabras.

\subsubsection{El procesamiento de la imagen visual}

El lenguaje pictórico se estructura a partir de un sistema de signos que al igual que el texto tradicional muestra un mensaje; sin embargo, la representación es distinta y por tanto su proceso de comprensión.

Torres (2007) sustenta que "la imagen es una producción material humana concreta, objetiva y subjetiva, basada en datos sensoriales, para conocer y producir conocimiento, comunicar y producir comunicación, crear y recrear el mundo exterior en el mundo interior del hombre (y viceversa)", es decir, la composición del lenguaje visual se basa en niveles sintácticos, semánticos y pragmáticos de naturaleza distinta al del texto verbal, en consecuencia, la información icónica activa procesos de percepción y procesamientos particulares.

La recepción de la información visual comienza en el ojo, éste tiene la facultad de percibir luz y con ella el contorno, las líneas, las texturas y las demás características físicas de la imagen, esta información se conduce al lóbulo occipital que detecta los estímulos visuales, de manera casi automática la memoria sensorial selecciona los elementos que resultan significativos para caracterizar la imagen y luego ser procesada 
por la memoria de trabajo y, finalmente, configurarse como una imagen mental en la memoria de a largo plazo.

El procesamiento de la información implica la recepción de los estímulos externos, en el caso de la imagen visual el reconocimiento de las características formales que la constituyen, la composición visual, el nivel de iconicidad, la sinestesia de los personajes, la distribución espacial, etc., que generan en el sujeto la activación de operaciones cognitivas que permiten el reconocimiento de la estructura visual, es decir, en el plano denotativo de la imagen se lleva a cabo la reconstrucción sintáctica de la imagen visual fija, el lector reconoce el plano material de la misma, en consecuencia, la memoria sensorial y la memoria de trabajo constituyen en primera instancia los dos canales de percepción y procesamiento de la información visual (Anula Rebollo, 1998; De Vega y Cuetos, 1999).

El reconocimiento de la estructura visual permite al sujeto realizar la conexión de la información de entrada con la ya existente, es decir, inicia el proceso de interpretación mediado por la memoria de trabajo y los conocimientos previos depositados en la memoria de a largo plazo. Se ha considerado que esta lectura se da bajo un enfoque connotativo, denominado de esta manera porque no sólo se vincula con información meramente cognitiva, sino con las experiencias de tipo cultural y social de las que ha participado el sujeto, dando lugar a interpretaciones subjetivas frente a la imagen. Sin embargo, se debe tener en cuenta que la imagen posee una naturaleza discursiva que cobra sentido en el contexto en el que esté ubicada, por tanto, su proceso de comprensión al igual que el de los textos escritos tradicionales exige la 
intervención de los procesos cognitivos, la memoria y la relación del input con los esquemas ya existentes.

\subsubsection{El procesamiento de las claves lingüísticas y la imagen visual}

Los textos verbovisuales, es decir, aquellos textos que involucran claves lingüísticas e imágenes visuales se procesan en tres niveles:

a. Representacional. Se ve y se reconoce desde el entorno y la experiencia.

b. Abstracto. Se reduce a los componentes visuales y los significados emocionales.

c. Simbólico. Se recurre al amplio universo de los sistemas de símbolos codificados que el hombre ha creado arbitrariamente y al que describe un significado.

Según Sierra et al., (1995) sea cual sea el nivel, este proceso puede explicarse desde la teoría de la codificación dual propuesta por Paivio en 1971 y 1986 o procesamiento dual desarrollado por Marschark y Surian en 1989, al respecto se identifican dos posiciones que han debatido sobre la naturaleza de los códigos de representación de dibujos y palabras. La primera denominada teoría de acceso diferencial (Clark y Paivio, 1991; Jonhson et al., 1996) considera que los sujetos ante dibujos o palabras deben acceder a distintos sistemas semánticos con distintas relaciones asociativas y semánticas (Bajo, 1999) pero se presentan diferencias en el curso temporal de la activación de los mismos tipos de estímulos, alcanzando mayor impacto inmediato las imágenes visuales; la segunda identificada como teoría dual 
(Nelson et al., 1977; Glasser, 1992) asegura que existen dos tipos de representación en dos sistemas diferentes, su divergencia está en el orden en el que se produce el acceso a la representación (visual, fonológica, semántica).

Ballesteros (1999) afirma que:

[...] Las teorías de codificación dual suponen que dibujos y palabras se almacenan en distintos sistemas que difieren en el tipo de información con el que trabajan (visual versus verbal) y en las redes asociativas que conectan las unidades almacenadas en cada uno de ellos. (p. 719)

Así, los materiales concretos se recuerdan mejor que los abstractos porque se codifican en la memoria a largo plazo tanto en un código de imágenes como en un código verbal. Esta dualidad de codificación favorece que las codificaciones sean más elaboradas y distintivas (Sierra et al., 1995). Por tanto, estos modelos predicen que distintas combinaciones de estímulos de preparación (prime) y objetivo (target) deben producir distintos patrones de facilitación (priming). De esta manera, si el estímulo de preparación y el estímulo objetivo son de la misma modalidad la facilitación obtenida debe ser mayor que la facilitación que se obtiene cuando el estímulo de preparación y objetivo son de diferente modalidad. Los primeros datos muestran procesamiento disociativo entre dibujos y palabras, pero se identifica superioridad en el recuerdo de dibujos.

En cuanto a las teorías duales se han ejecutado ensayos de facilitación dentro de la misma modalidad (dibujo-dibujo, palabra-palabra,) mostrando efectos de facilitación en distintas tareas (Sperber et al., 1979; Carr et al., 1982; Storkel y Adlof, 2009), el patrón de resultados obtenido en los experimentos que buscaban efectos de 
facilitación a través de modalidades es bastante complejo. Durso y Johnson (1979) encuentran facilitación entre modalidades en una tarea de denominación cuando un dibujo es precedido por su nombre (facilitación palabra- dibujo) pero no hallan facilitación cuando una palabra es precedida por un dibujo que representa el mismo concepto (facilitación dibujo- palabra). Scarborough et al. (1979) obtienen resultados similares en una tarea de decisión léxica. Decidir que un conjunto de letras es una palabra facilita la presentación y lectura previa de su nombre, pero no por la presentación y denominación de su dibujo correspondiente.

Carr et al. (1982) encontraron efectos significativos de facilitación dibujo-palabra en tareas de denominación, sin embargo, estos efectos eran muy pequeños (8 y 15 ms.). Aunque en un principio este patrón de resultados parecería favorecer a las teorías duales, la mayor parte de los estudios descritos en los que no se obtiene facilitación a través de la modalidad dibujo-palabra utilizaron tareas de denominación en las que se pedía a los sujetos que leyesen las palabras que aparecían en la pantalla. Perfetti y Bell (1991) proponen desde las teorías de denominación que la lectura de una palabra no requiere necesariamente de la activación de su representación semántica y es posible que no se obtengan efectos de facilitación semántica dibujo-palabra porque cuando hay que nombrar palabras, no se produce este tipo de activación y puede llegar simplemente al procesamiento fonético. Un argumento a favor es el hecho que los experimentos que no muestran facilitación dibujo-palabra tampoco muestran facilitación palabra- palabra.

Por consiguiente, el problema no parece ser el cambio de modalidad sino el que la tarea no requiera procesamiento semántico. Bajo (1999) en su primer experimento 
de 1988 manipuló el tipo de tarea que los sujetos debían realizar y también modificó la modalidad del estímulo objetivo y de preparación, de manera que a través del experimento aparecían todas las combinaciones de modalidad. Entonces, podría afirmarse que dibujos y palabras acceden al mismo tipo de representación semántica, dependiendo del orden de acceso, la facilitación y las exigencias de la tarea.

Por su parte, las teorías de acceso diferencial predicen (Nelson et al., 1977; Glasser, 1992) que cuando el estímulo objetivo es un dibujo habrá facilitación debido a que los dibujos necesitan acceder a su representación semántica para poderse nombrar. La presencia de un estímulo previo relacionado semánticamente debe activar la representación semántica del dibujo objetivo y facilitar la respuesta de igualación del nombre. Cuando, sin embargo, el estímulo objetivo es una palabra, ésta puede acceder a su representación fonológica directamente sin necesidad de activar su representación semántica. En consecuencia, los efectos pueden no aparecer independientemente de que el estímulo previo sea un dibujo o una palabra. En otras palabras, los dibujos siempre requieren de acceso semántico para denominarlos, mientras que las palabras dependen de la estrategia de lectura utilizada, el acceso a su representación fonológica puede ocurrir sin necesidad de que se acceda a la representación semántica. Un dibujo tiene una activación fonológica más lenta (verbalización) y se ve facilitado en mayor medida por la presentación previa de un estímulo que comparte esta información. La combinación dibujo-dibujo produce efectos equivalentes a la condición palabra-dibujo y la combinación palabra-palabra produce efectos equivalentes que la combinación dibujo-palabra. Por lo tanto, la facilitación fonológica o semántica no depende de que el estímulo previo sea o no de la misma modalidad, indicando que la representación 
fonológica a la que acceden dibujos y palabras es común a ambos, varían en el curso temporal de activación de distintos tipos de información.

Sierra et al. (1995) retoman el modelo semántico sensorial (Figura 6) propuesto por Nelson, Reed y Wallina. En él se establece que la mayor efectividad de las imágenes se debe, por un lado, al acceso directo de las imágenes al contenido semántico; de tal manera que el material pictórico produce codificaciones cualitativamente diferentes al material verbal. El material pictórico favorece el almacenamiento y la recuperación de la información en la memoria a largo plazo, lo que facilita su comprensión y mantenimiento con más exactitud que el material verbal gracias a la superioridad mnésica.

\section{Figura 6}

Modelo semántico sensorial de Nelson, Reed y Wallina

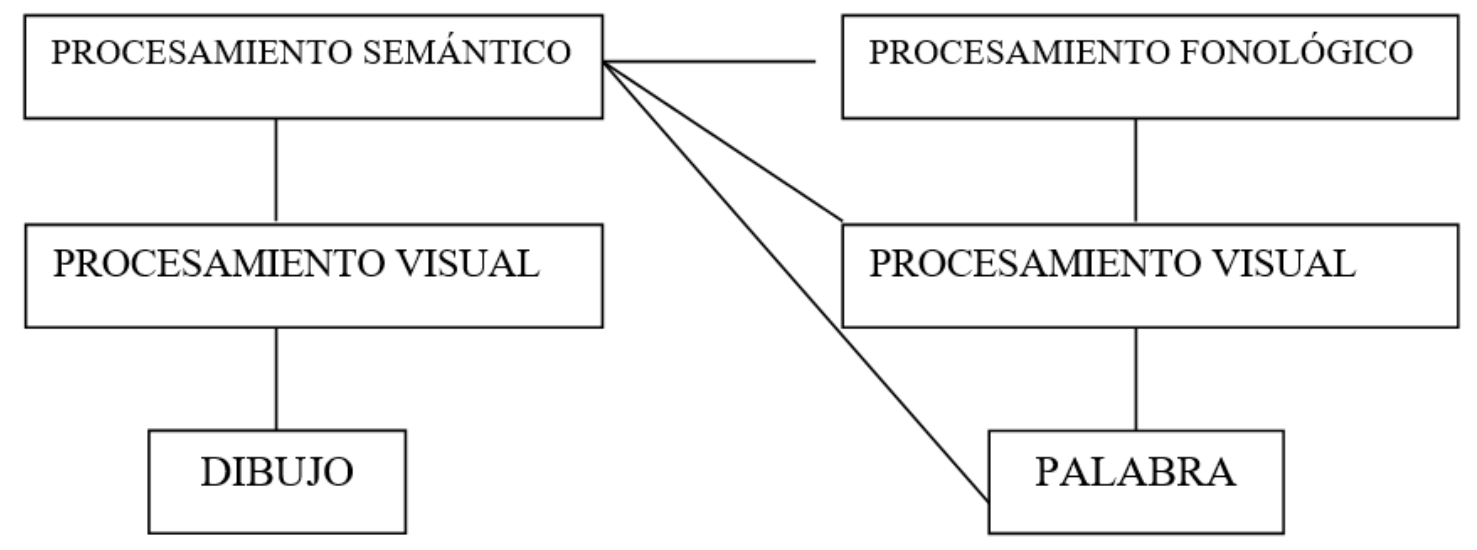

Fuente: Citado en Sierra et al. (1995)

En el procesamiento de las palabras inicialmente se accede a la representación léxico-fonológica y después a la representación semántica, por ello, puede presentarse tareas de lectura con o sin procesamiento semántico. Por su parte, en el procesamiento 
de los dibujos se accede directamente a la representación semántica, por tanto, “[...] Los dibujos deben entenderse antes de denominarse" (Bajo, 1999, p. 884). No obstante, no existe evidencia de sistemas distintos y es probable que con suficiente tiempo de procesamiento dibujos y palabras acceden al mismo tipo de representación, pero difiriendo en el orden en que acceden al mismo (Bajo, 1999). Al respecto, Sierra et al. (1995) sugieren que la información pictórica estimula la elaboración cognitiva, dando lugar a una codificación más extensa en términos de una red semántica más amplia, con mayor número de rutas de acceso, lo cual incrementa la probabilidad de que la información sea recuperada en posteriores tareas.

A semejanza del texto escrito las imágenes son capaces de configurar textos icónicos con una estructura morfológica, sintáctica y semántica. La lengua se configura a través de los vínculos que establecen significantes y significados. La palabra es una imagen acústica que se remite a sentidos regulados por una comunidad hablante. De forma análoga la imagen, como significante, también remite a sentidos, ciertamente menos restringidos que los verbales, pero siempre corroborados por una comunidad de "mirones", de observadores (Puerto, 2015, p. 39).

\subsection{MODIFICABILIDAD COGNITIVA}

Feuerstein (1990) desarrolla un sistema de evaluación denominado Programa de Evaluación Dinámica de la Propensión al Aprendizaje (E.D.P.A). El objetivo es fortalecer las capacidades y promover los cambios cognitivos que una persona puede exhibir durante el proceso de experiencia de aprendizaje mediado. Parte de la premisa de que el ser humano es un organismo abierto al cambio, flexible, receptor a la 
intervención positiva de otro ser humano e inteligente gracias a un proceso de autorregulación dinámica que se modifica en interacción con los factores del medio.

Algunos planteamientos centrales son: la inteligencia es una capacidad dinámica del ser humano; se pueden diseñar ambientes modificantes; la modificabilidad cognitiva estructural es una capacidad propia del hombre; la experiencia del aprendizaje mediado se potencializa por la interacción entre receptor, estímulo y mediador; el mapa cognitivo es la base de la comprensión de las diferencias entre los individuos.

Entonces, la Evaluación Dinámica de la Propensión al Aprendizaje se erige como un dispositivo que permite la detección de los procesos del pensamiento en el individuo y es una herramienta práctica que permite llevar a la realidad el mejoramiento de la inteligencia (Feuerstein,1990).

Feuerstein (1990) sostiene que existen dos causas que influyen en el desarrollo cognitivo de los organismos. Las causas distales relacionadas con los aspectos etiológicos y compuestas por los factores genéticos, la configuración del organismo (madurativo y ambiental), los niveles emocionales y educativos; no tienen incidencia en las diferencias en el desarrollo cognitivo y el grado de modificabilidad. Las causas proximales asociadas a la carencia de un aprendizaje sistematizado, la motivación y la mediación; directa e inevitablemente son responsables de las diferencias en el desarrollo cognitivo y la modificabilidad.

El autor aclara que la modificación es el resultado de los procesos de maduración y de desarrollo, en consecuencia, es natural a todos los individuos ya sea frente a estímulos con una organización aleatoria o con una sucesión direccional organizada. No obstante, la modificabilidad es un cambio en las estructuras que se 
alejan de la curva normal del desarrollo previsto por las condiciones genéticas, neurofisiológicas y/o educacionales, es decir, es el resultado de una intensificación intencionada de estímulos según condiciones particulares, tomando protagonismo las causas proximales. Ahora bien, para que haya éxito en la experiencia de aprendizaje mediado, el mediador debe estar convencido de que los seres humanos son modificables, por tanto, el individuo con el cual se trabaja es modificable, el mediador es capaz de modificar al individuo, el mediador es sí mismo puede modificarse, la sociedad es modificable y tiene que ser modificada (Feuerstein, 1990).

Feuerstein (1990) plantea que la exposición directa del organismo a los estímulos del ambiente y la experiencia de aprendizaje mediado determinan el desarrollo cognitivo diferencial de una persona. La primera, referida a los cambios que producen los estímulos del ambiente en las características psicológicas determinadas genéticamente; y la segunda, a la interacción activa entre las fuentes internas y externas de estimulación que intensifica las habilidades del sujeto. En este sentido, modificarse es exponerse a ciertas experiencias en la que influye la naturaleza del sujeto y los modos de interactuar con el mundo. Se reconoce que la maduración por sí misma no cambia esquemas, se necesita una intencionalidad en la exposición a estímulos particulares, basarse en un repertorio de disposiciones, proponer orientaciones, actitudes y técnicas que permiten modificar con respecto a los otros estímulos. Se define la estructura del aprendizaje, el contenido a aprender, los beneficios de situaciones de aprendizaje, la propensión y la emoción que impulsa a aprender. Una experiencia de aprendizaje mediado permite al sujeto decidir sobre qué 
ver, dónde mirar, cuánto tiempo invertir en percibir el estímulo y cómo integrar las partes.

La experiencia de aprendizaje mediado se caracteriza principalmente por la intencionalidad y la reciprocidad de los procesos, tanto el mediador como el mediado deben saber cuál es el objetivo proyectado y sus responsabilidades en ello. La trascendencia que apunta al reconocimiento del impacto inmediato y mediato de la intervención. La mediación del significado para el mediado, direccionado a explicitar el qué y para qué del sujeto respecto a las tareas en las que participa, la fuerza emocional que permite asignar significación a lo que se hace (Feuerstein, 1990).

Teniendo en cuenta lo expuesto, Feuerstein et al. (1999), puntualizan que desde la teoría de la modificabilidad cognitiva cualquier individuo al interactuar con los estímulos adecuados podrá alcanzar un aprendizaje mediado independiente a los determinantes distales o genéticos y los determinantes próximos o del ambiente. En este sentido, cobra importancia el mediador (docente o experto), la motivación del sujeto (aprendiz), las características del material y las tareas a resolver. Plantean que el protocolo de desarrollo de las actividades debe responder a la siguiente progresión:

Paso uno. El experto hace, el aprendiz observa

> Paso dos. Experto hace, el aprendiz ayuda. El aprendiz hace, el mediador revisa y muestra solución de problemas. El aprendiz trabaja por sí solo. Si no tiene éxito, el mediador inicia solución del problema y aprendiz completa. Si no tiene éxito, se ofrecen pistas. Si persiste el problema se alienta permanentemente hasta hallar respuesta. Se modifica el comportamiento y los procesos internos. 
> Paso tres. El aprendiz hace, el experto ayuda.

> Paso cuatro. El aprendiz hace, el experto observa.

El proceso descrito exige la evaluación permanente, lo que permite realizar ajustes y crear oportunidades de aprendizaje, se presenta un traspaso paulatino de la responsabilidad y la conquista de la autorregulación. Los aprendices se exponen a estímulos internos y externos que promueven cambios en las estructuras mentales gracias al ambiente y la mediación (Noguez Casados, 2002)

A diferencia del desarrollo motivado por experiencias fortuitas, los cambios estructurales como el que propone Feuerstein reflejan la manera integral en que una persona elabora y responde a la información y los estímulos por lo cual requiere de una mediación especial que permita obtener los mayores beneficios de la información. Modificar estructuras cognitivas promueve un crecimiento continuo a medida que se dé una adaptación a las exigencias de la vida y del medio ambiente (Maclure y Davis, 1994).

La modificabilidad cognitiva estructural no es solamente una directriz para el proceso de enseñanza y aprendizaje, no es una receta para ser un mejor mediador y lograr buenos estudiantes, es una filosofía optimista que se va en contra de los factores negativos dados por la genética, la herencia o la calidad de vida adversa. El credo de Feuerstein es que todo ser humano es modificable y para que esto acontezca es preciso entender la mediatización (también mediación) como una estrategia de intervención por medio de un mediatizador o mediador que intente producir efectos en el organismo del mediatizado, buscando mejor eficacia en el procesamiento de la información (Orrú, 2003). 


\subsection{EL CUENTO GRÁFICO: ¿QUÉ ES?, ¿DE DÓNDE VIENE?}

El cómic tuvo su origen en Europa en el siglo XVIII pero fue en Estados Unidos a finales del siglo XIX donde, gracias a los periódicos, se populariza y se difunde tanto en este país como en el mundo. Inicialmente se empleaban para captar lectores para los diarios. Sossa (2019) indica que más que una estrategia de mercadeo se crea una estética propia, emparentada con el cine, la ilustración de libros y los carteles publicitarios. Su historia inicia con historietas de simple humor, aventura, acción, misterio, de tipo satíricas, políticas, de denuncia social, eróticas o de terror, nada de lo humano le es indiferente. El cómic fue un fenómeno de masas extendido antes que la televisión.

Los cómics book o las revistas de historietas nacen en 1933, aunque 1987 se reimprimen historietas que habían sido publicadas en periódicos. Los temas son moralistas, lo que rápidamente disminuye el interés en los lectores. En 1947, el editor Max Gaines crea nuevas historias atractivas, entre ellas la de Crimen Patrol caracterizada por la presencia de sangre, crímenes, cadáveres y escenas violentas; no solo se diversificaron los temas sino que se inicia el cómic moderno con historias como verdadero arte, empleando criaturas horripilantes, extraterrestres, asesinatos, brujas, espantos y cadáveres ambulantes. Las revistas se multiplican, se inundan de historias que buscan robar el sueño a los espectadores. Su característica fundamental es la ruptura de los códigos morales y religiosos, se mantiene al lector en expectativa, se desconfía, se sospecha, no hay héroes sino protagonistas enlazados por destinos favorables o desfavorables, se aborda lo trágico de lo cotidiano bajo la idea de que "[...] la vida es cuestión de supervivencia, no de moral" (Sossa, 2019, p. 111). 
Tal libertad se mantiene hasta que el psiquiatra Fredric Wertham en 1954 publica su libro La seducción de la inocencia, en el que acusa a los cómics, especialmente a los de terror, de ser causantes de la violencia juvenil; lo que ocasiona limpiar las diferentes producciones y la reducción a la mitad de las publicaciones, se cierran editoriales. Sobrevive la revista Mad centrándose en la sátira mordaz, la ironía, el humor negro. Se incrementa la preocupación por la presencia del sexo y la violencia en los cómics book; se crea Comic Code Authority cuya función es censurar los cómics. El cómic de terror retorna después que se aminora la censura apoyándose en el tema sobrenatural, dándole mayor énfasis a los aspectos estéticos tales como los trazos, los planos, la diagramación de viñetas, el manejo de la luz y el sombreado (Sossa, 2019).

En la década de 1970 con el cómix underground o de publicación clandestina se enfatiza en la exageración del cuerpo humano, se experimenta con el color y diversas técnicas de ilustración, el estilo es deliberadamente grotesco, se critica de forma feroz y directa a las instituciones políticas, religiosas, militares y culturales, transforman al superhéroe infalible por personajes retratados desde la realidad de la sociedad y sus problemáticas. La ola pasa, pero la influencia queda. Después surgen los cómix overground, se evoluciona a producciones más agradables desde lo gráfico, conservadoras, mejorando el estilo argumental sin mayor dinamismo, con destape erótico, deja de ser contestatario y crítico. La novela gráfica cobra un nuevo impulso bajo la influencia del comix underground y alternativo, es la madurez de la historieta (Sossa, 2019). 
La novela y el cuento gráfico son hijos del cómic. Utilizan los mismos medios pero cambian las temáticas. Es por ello que se consideran una modalidad del cómic, que lo ha revitalizado especialmente a partir de la década de 1990.

La novela gráfica es el cómic hecho libro. Tiene un fondo literario más pensado y profundo que el simple relato de acción. La línea entre el cómic y la novela gráfica es difusa. La última relata la vida, cuenta historias y testimonios sobre el acontecer humano, es arte que puede conmover o estremecer; lo que importa es la calidad, la profundidad, el valor como obra de arte, de pensamiento y de imaginación. A los autores los destaca ser independientes y no preocuparse por la producción en masa y la creación de historias estereotipadas o reiterativas. El cuento gráfico es de la misma naturaleza de la novela gráfica en cuanto a intenciones comunicativas, estructura, temáticas y estética, la diferencia radica en constituirse en historias más intensivas con una sola línea argumental, de corta extensión (entre 5 y 20 páginas) y su publicación puede ser seriada (García, 2010).

Sossa (2019) afirma que Will Eisner fue quien impulsó dicha categoría con obras como Contrato con Dios y otras historias de Nueva York, bañando sus textos con dramatismo, intensidad y personajes definidos. Al igual destaca la figura de Art Spiegelman con Maus, por su impacto en el medio y el posicionamiento del oficio basado en la calidad narrativa, uso de recursos estéticos, estilo renovado conceptualmente, marca un antes y después de la narrativa dibujada. Adicionalmente, resalta obras como Persépolis de Marjane Satrapi, Marzi de Sylvain Saoia y Marzena Sowa, Todo Paracuellos de Carlos Giménez, Las calles de arena de Paco Roca, Vals con Bashir de Ari Folman y David Polonsky, Watchmen de Allan Moore, el Caballero 
Oscuro de Frank Miller. Estos textos tienen en común el uso de temáticas biográficas, recurrir a testimonios, usar sus voces para hacer denuncia social, reconstruir la historia de personas y pueblos, escudriñar en las relaciones de pareja y en la vida del hombre común. Los personajes son acosados por miedos, dudas, amores, muertes, instantaneidad del tiempo, las derrotas y las frustraciones.

En Latinoamérica se destaca en la producción cómic, novelas y cuentos gráficos La Argentina, México, Brasil y Chile, enfatizándose la recurrencia a temáticas sociales y contestarias. En Colombia hasta 1970 llega la literatura gráfica de varios países, pero por los altos costos tributarios su difusión mermó, la cual se activó cuarenta años después; la producción nacional es incipiente, la circulación de novelas gráficas y manga japonés está en ascenso, álbumes ilustrados son mucho más populares porque se fomenta su uso en las escuelas (Sossa, 2019).

\subsubsection{El cuento gráfico como texto multimodal y verbovisual}

En 1990 comienza a extenderse el interés por el estudio del texto multimodal (llamado por Parodi multisemiótico), apuntando bien a su estructura o a la forma de producción. Halliday (1978) desde la lingüística sistémico funcional ya mencionaba aquellos textos que no implican solo lo lingüístico. Pero son Kress y Van Leeuwen (2001), Kress y Threadgold (1988) y Kress (2003) quienes hablan del texto multimodal, es decir, aquellos que para su diseño se emplean varias modalidades y canales tales como el sonido, los gestos, la imagen, la letra, además, tienen una carga social en su manera de significar (Parodi, 2014, 2005). 
La teoría del texto multimodal surge del reconocimiento del autor y el lector, su interacción y como en ella se despliegan potencialidades de significación que poseen tanto los elementos materiales de producción como los propios sistemas semióticos con sus respectivas permisibilidades (Kress, 2003). Comprender el texto multimodal es cambiar la concepción que se tiene sobre qué es un texto. Desde la multimodalidad, el texto no es la composición sino el diseño, se usa conscientemente sistemas semióticos con valores sociales, modos, medios y sitios de despliegue con un propósito según un problema retórico; su recepción es la reconstrucción del signo según caminos de interpretación, lo que supone conciencia en la elección de los sistemas semióticos en los que se alterna información del texto, conocimientos previos y horizontes de expectativas (Kress y Bezemer, 2009). Entonces, el texto es un producto social, una construcción conjunta.

En el marco de este tipo de texto con diferentes modalidades (Kress, 2003) o en los que conviven varios sistemas semióticos (Parodi, 2014) se encuentran los textos verbo-visuales, en los que se erige de forma intrincada las letras y la imagen visual. Para efectos de la investigación se seleccionaron cuentos gráficos que hacen parte de la llamada narrativa gráfica o relatos dibujados (Ossa, 2019).

Abril (2007) afirma que el análisis del texto visual debe ser interdisciplinario desde un marco semiótico, es decir, que se enmarca en la subjetividad, la experiencia visual en cualquiera de sus formas, las categorías de análisis del texto y el discurso como puente inter-teórico, y la dinámica de transformación. Sin olvidar que este tipo de texto se caracteriza por la no inmanencia, es decir, por la aceptación de la influencia en el texto verbovisual de factores extralingüísticos propiciados por el contexto. El autor 
aclara que la interpretación semiótica no está limitada a la codificación de mensajes, ya que las actividades del emisor y del receptor son interdependientes. Esto ha propiciado que se hable de sujetos de la comunicación. El análisis semiótico asume que el texto es multiacentuado y nunca prefijado. Por ende, las denotaciones de este se convierten en connotaciones con facilidad, dado que tiene en cuenta las condiciones históricoculturales que suponen lo contextual, lo reflexivo y lo discursivo. El autor hace referencia a la semiosis ilimitada definida por Peirce como la interpretación que puede ser inmediata, dinámica o final. El objeto del signo presupone llevar a cabo inferencias y razonamientos.

El texto visual propicia la oportunidad de determinada experiencia para un sujeto productor-intérprete y el nivel visual atiende a la percepción de los receptores sensoriales durante el encuentro con el objeto. Por otra parte, el nivel de la mirada está determinado por la subjetividad y la dimensión de la imagen, la representación y la autorregulación de los imaginarios. La mirada es entendida como visión modalizada y hecho sociocultural, es decir, que involucra esquemas previamente determinados, y por ende es particular dependiendo del contexto. Desde la perspectiva semiótica es un discurso y un proceso de enunciación. La experiencia visual está sometida a condiciones espacio temporales frecuentemente variables. La visualización, entonces, se presenta fijada por distintos factores, verbigracia: procesos cognitivos básicos y complejos.

Abril (2007) indica que la imagen como producto de la imaginación atiende a la carencia de algo, lo representante está en lugar de lo representado. El texto 
verbovisual está dado de una u otra manera por la subjetividad en torno a esta de acuerdo con el contexto y a las variables que pueden influir.

El texto verbovisual puede ser estudiado en varias dimensiones: pragmática y semántica. La primera se entiende que el sentido de todo texto remite a una práctica sociodiscursiva determinada por una diversidad de aspectos y a un universo semántico-simbólico; los discursos escritos o verbovisuales son secundarios, esto quiere decir que depende de la configuración de los primarios: los orales. La segunda, apunta a universos de significados y simbólicos que implican reflexión, es la estructura profunda y de matriz de significación en forma relativa a las prácticas discursivas. En la eficiencia simbólica se deben tener en cuenta dos polos: el sensorial, que tiene en cuenta comportamientos ligados a la forma externa del signo y el ideológico, que asume las ideas y valores dependiendo de la sociedad. En las prácticas sociales, las figuras literarias son sumamente simbólicas y sus lecturas son plurales, teniendo en cuenta la enunciación, el modo y el destinatario textual.

La imagen visual fija amplía el horizonte de la comprensión textual, la imagen puede tomar lugar en el texto como un elemento accesorio, complementario o central. En este sentido, el cuento gráfico, es un texto donde las palabras y los dibujos se complementan para componer un relato integral, con una fuerte preponderancia gráfica que, mediante la lectura visual, incita al lector a una interpretación narrativa que va más allá de las palabras (Villar, 2016).

Vernon-Lord (1997) reconoce el grado de significancia, las propiedades representativas y las funciones comunicativas de la ilustración, que son importantes no 
sólo en el proceso de lectura, sino en la interiorización del mensaje por parte del sujeto, sustenta que:

La ilustración es un arte instructivo: ensancha y enriquece nuestro conocimiento visual y la percepción de las cosas. A menudo interpreta y complementa un texto o clarifica visualmente las cosas que no se dejan expresar con palabras. Las ilustraciones pueden explicar el significado mediante esquemas o diagramas o exponer conceptos imposibles de comprender mediante una manera convencional. Pueden reconstruir el pasado, reflejar el presente, imaginar el futuro o mostrar situaciones imposibles en un mundo real o irreal. Las ilustraciones pueden ayudar, persuadir y avisar de un peligro; pueden desperezar consciencias, pueden recrear la belleza o enfatizar la fealdad de las cosas; pueden divertir, deleitar y conmover a la gente. La ilustración es, en general, una forma de arte visual representativo o figurativo, pero su carácter o especial naturaleza -esas engañosas cualidades mágicas que le han sido concedidas en el proceso de dibujarla o pintarla- pueden hacer que vaya más allá del sujeto o contenido descrito. (p.168)

Con lo anterior, se asume que la imagen no acompaña el contenido del texto de manera infundada, sino que genera sensaciones en el sujeto, por su grado de plasticidad, realismo e iconicidad dando lugar al surgimiento de relaciones semánticas entre la ilustración, las experiencias sociales y culturales que ha experimentado el lector, nutriendo así el proceso de comprensión. 


\subsubsection{Estructura y comprensión de cuentos gráficos}

Hoster y Gómez (2013) afirman que la lectura de textos verbo-visuales requiere que el sujeto reconozca la dimensión espacial de la composición y la dimensión temporal del ritmo narrativo, al igual que las ilustraciones que no sólo reconstruyen la secuencia episódica de la historia, sino que por medio de ellas se perciben las características del espacio, los perfiles de los personajes y las acciones de los mismos, para ello, es necesario el reconocimiento de algunos de las características formales de este tipo de textos. En el proceso de interpretación se debe tener presente que tanto el código textual como el visual pueden dar o delimitar información; sin embargo, existe una relación de complementariedad, que de no presentarse carecería de lo que se denomina sinergia.

Las imágenes visuales ocupan un lugar de interés en los estudios pragmáticos propiciando el surgimiento de propuestas de caracterización relacionadas con el código verbal, de esta manera se ha determinado que, de acuerdo a la intencionalidad del autor, las relaciones de la imagen visual con las claves lingüísticas pueden agruparse en: descriptiva, cuando la imagen visual logra mostrar una parte o totalidad de las claves lingüísticas; alusiva, cuando la imagen visual tiene relación directa o indirecta con las claves lingüísticas; y sugestiva, se da cuando la imagen visual presenta un elemento que genera sensación en el lector. Desde allí han surgido posturas teóricas que se enfocan en su interrelación y cómo puede influir en el proceso de percepción, la conexión de la información de entrada con la ya existente y, por tanto, con la comprensión del texto. 
Delgado (2005) sustenta que la narrativa gráfica es el resultado de un ensamble verbo - icónico, que le otorga diferentes grados de representación y carga semántica a la imagen dentro del texto. En este sentido propone tres categorías: la primera, la ilustración, se da cuando la imagen es parte central del texto; la segunda, la expresión básica, la imagen ocupa un lugar accesorio en el texto y la tercera, la complementariedad, la imagen y el texto se interrelacionan. La última es la que predomina en el contenido del cuento gráfico donde la imagen amplía el significado conceptual dado por la información verbal.

Los cuentos gráficos, como toda la literatura gráfica, siguen pautas para que las ilustraciones vayan acorde al contenido (Salisbury y Styles, 2012; McCloud, 2008):

> Composición: la composición es la distribución dentro de un espacio de elementos visuales a fin de componer una imagen. Se tiene en cuenta la forma, el tamaño, la textura, la distancia, el balance, la armonía.

Encuadre: se refiere a los planos o espacios físicos que se abarcan dentro de una imagen, en este caso, en una viñeta de cómic. Por ejemplo: el plano general (que abarca un elemento mostrándolo en toda su extensión junto con su entorno), plano medio (que muestra el pecho, cuello y cabeza del personaje), primer plano (enfocado principalmente en el rostro del personaje), primerísimo primer plano (cuya finalidad es mostrar al lector un detalle).

Fondo: representación del espacio físico en que se encuentran uno o varios personajes o en el que suceden una o más acciones. El fondo puede ser el protagonista de una viñeta, por ejemplo cuando se busca ambientar al lector; o puede obviarse de una viñeta si no es relevante para la misma. 
Globo: espacio delimitado que se destina normalmente al texto, sea la voz o pensamientos de los personajes, la descripción de un narrador, etcétera. Tradicionalmente el globo de texto ha sido representado con forma de nube, pero muchos autores han experimentado con otras formas que potencian la expresividad del mismo, como un globo de texto de extremos puntiagudos que representa una expresión violenta, el globo de texto doble que representa la voz escuchada a través de un teléfono o medio de transmisión digital, e incluso ciertos artistas han optado por no dibujar globos, usando en cambio el texto en un espacio vacío y vinculándolo al personaje que lo dice mediante una línea o sin ella.

$>$ Guion: herramienta que sirve como guía para el escritor de cómics al momento de dibujar; el guion literario, por ejemplo, es un resumen más o menos breve en forma de narración de los acontecimientos que suceden a lo largo de la historia, mientras que el guion técnico describe la distribución de dicha historia en páginas, y el contenido de las viñetas que las conforman.

$>$ Gutter: es el espacio entre dos viñetas, ya sea horizontal o vertical. Según McCloud (2008) en el gutter es donde sucede realmente la acción en un cómic, pues permite al lector "cerrar" dos viñetas consecutivas creando así una secuencia de acciones.

Por otra parte, el cuento gráfico se rige desde distintos enfoques que ayudan a la línea argumental del texto y a la fluidez icónica. McCloud (2008) los sintetiza de la siguiente forma: 
Con enfoque en la palabra: es cuando el arte está encaminado únicamente a ilustrar un texto descriptivo. Aquí el dibujo no agrega nada a la información provista por el texto.

$>$ Con enfoque en el arte: la palabra escrita, si es que llega a haberla pues puede ser omitida, es más una especie de acompañamiento a la imagen visual, esta última puede subsistir y transmitir su mensaje de forma independiente. En muchas ocasiones el texto que se presenta en este tipo de relación no pasa de la onomatopeya.

$>$ Con un enfoque dual: en el que, tanto palabra como dibujo, transmiten exactamente el mismo mensaje.

$>$ Con enfoque en paralelo: palabra y dibujo tienen poco que ver la una con el otro. El texto transmite una idea, mientras que el dibujo provee de un mensaje separado.

$>$ Con forma interdependiente: tanto la palabra como la imagen van de la mano y se complementan para narrar una historia, sin que uno sea más importante que el otro, sin que sean redundantes en el mensaje. Sin la palabra, la imagen se percibe incompleta, sin la imagen, la palabra pierde sentido.

La correlación entre la imagen visual y las claves lingüísticas condiciona un tipo de lectura distinta a la que se realiza de un texto verbal, requiere de la activación de procesos cognitivos que inician en la percepción visual y se van anclando a procesos más complejos dados en la memoria y el pensamiento del sujeto. Nikolajeva y Scott (2001) sustentan que la lectura de la imagen visual y las claves lingüísticas se puede explicar a partir de cinco categorías: la primera, la interacción simétrica, se asume que 
tanto las palabras como la imagen cuentan la historia de manera sincrónica; la segunda, la interacción de la ampliación, esto sucede cuando algunos de los dos códigos completa al otro, es decir, cuando la imagen extiende el significado de la palabra o la palabra el de la imagen; la tercera, la complementaria, se da cuando uno de los dos códigos aportan información más significativa y distinta que el otro; la cuarta, es la de contrapunto, se establece cuando la imagen y la palabra cuentan la historia de manera distinta o desde un ángulo diferente; y la quinta, la contradictoria, la imagen y la palabra muestran la historia de manera opuesta. Argumentan que esta ambigüedad exige al sujeto reconocer los componentes de cada uno de los códigos sugiriendo así la concreción de procesos cognitivos dirigidos a la reconstrucción de la historia, porque bajo estas condiciones, tanto la ilustración como el texto admiten plurales interpretaciones. La naturaleza representativa de la ilustración muestra aquello que al texto resulta difícil de describir, asumiendo parte de la carga narrativa y la transmisión de ideas complejas y extensas.

Así mismo, los semiólogos han clasificado los distintos niveles del ensamblaje verbo - icónico de acuerdo con la relación que se dé entre el texto visual y el texto escrito (Niño, 2008):

$>$ Relación de redundancia, se da cuando la imagen y el texto proporcionan la misma información.

Relación de aclaración, ocurre cuando uno de los códigos amplía el contenido del otro.

Relación de convencionalidad, se da cuando ambos códigos no tienen relación directa y se genera una interpretación de carácter connotativo. 
Relación de desconexión, el código verbal no tiene conexión explícita con el código visual. Condición que exige un mayor grado de concentración y de procesamiento de la información por parte del sujeto.

$>$ Relación de manipulación, el código visual se usa como un recurso discursivo para crear contrastes, representaciones, asociaciones, etc.

Los elementos mencionados son indicadores de que el cuento gráfico es un texto cada vez más impactante en los espectadores, que propicia un valioso conjunto de lecturas que se obstina en romper moldes y llegar siempre más allá de cualquier etiqueta: una lectura sin edad, a medio camino entre la literatura y la creación plástica, abierta a diversidad de técnicas y lenguajes, sin límite de formatos e ideal para divertirse, reflexionar, soñar, aprender, regalar.

\subsection{RECAPITULACIÓN}

En la presente investigación se entiende la comprensión como una reconstrucción de sentidos y representaciones, que parte del surgimiento de inferencias en las que la información textual propicia la activación de conocimientos previos, ya sea durante o posterior a la lectura. Implica mecanismos inhibitorios que evitan la saturación de la representación del texto y mecanismos de activación de información que permiten establecer secuencias semánticas que conducen a la comprensión. Emprender su estudio exige entenderla como una actividad cognitiva que involucra procesos de decodificación de los niveles de la lengua e imágenes visuales, que conducen a activar y procesar información textual y previa encadenada a esquemas, 
cuyo procesamiento necesita la intervención de los sistemas de memoria sensorial, de trabajo y a largo plazo.

La percepción, sea de las claves lingüísticas o las imágenes visuales, corresponde al proceso psicológico de la interpretación significativa, al conocimiento de las cosas y los hechos del mundo exterior transmitida por medio de los sentidos, resultado de un estímulo o impresión luminosa registrada por los ojos. Fisiológicamente los sujetos comparten el acto óptico-visual-mecánico, pero se registran divergencias en cuanto a cultura, educación, edad, memoria, estilo cognitivo y estado emocional. Independientemente de lo innato o empírico que sea la percepción demanda un proceso instruccional y su falencia ocasiona dificultades en el procesamiento textual. Se debe tener en cuenta que la imagen posee una naturaleza discursiva que cobra sentido en el contexto en el que esté ubicada, por tanto, su proceso de comprensión al igual que el de los textos escritos exige la intervención de los procesos cognitivos, la memoria y la relación del input con los esquemas ya existentes.

El modelo semántico sensorial propuesto por Nelson et al. (Sierra et al., 1995) resulta explicativo puesto que destaca la efectividad de las imágenes debido al acceso directo de ellas al contenido semántico, favorece el almacenamiento y la recuperación de la información en la memoria a largo plazo, lo que facilita mantenimiento con más exactitud gracias a la superioridad mnésica; así mismo, la imagen visual tiene una activación fonológica más lenta (verbalización) y se ve facilitada en mayor medida por la presentación de un estímulos con los que comparte información previa. Mientras que las claves lingüísticas dependen de la estrategia de lectura utilizada, el acceso a su representación fonológica puede ocurrir sin necesidad de que se acceda a la 
representación semántica. No obstante, no existe evidencia de sistemas distintos y es probable que con suficiente tiempo de procesamiento la imagen visual y las claves lingüísticas acceden al mismo tipo de representación, pero difiriendo en el orden en que acceden al mismo.

En el marco de textos con diferentes modalidades [multimodal] (Kress, 2003) o en los que conviven varios sistemas semióticos [multisemiótico] (Parodi, 2014) se encuentran los textos verbo-visuales, en los que se vinculan de forma intrincada las claves lingüísticas y la imagen visual. Para efectos de la investigación se seleccionaron cuentos gráficos que hacen parte de la llamada narrativa gráfica o relatos dibujados (Ossa, 2019). La correlación entre la imagen visual y las claves lingüísticas condiciona un tipo de lectura distinta a la que se realiza de un texto verbal, requiere de la activación de procesos cognitivos que inician en la percepción visual y se van anclando a procesos más complejos de procesamiento. En cada uno de los cuentos gráficos seleccionados, las claves lingüísticas y la imagen visual se erigen como una unidad textual fundada en relaciones de alusión, complementariedad, interdependencia, simetría y redundancia. En su procesamiento se establecen conexiones entre lo verbal y lo icónico, se organizan redes conceptuales, se busca fuera del texto informaciones y conocimientos con los cuales se rellenan los huecos textuales. 


\section{CAPÍTULO 2}

\section{RUTA METODOLÓGICA}




\subsection{INTRODUCCIÓN}

En el capítulo 2 se presentan y describen los principales postulados metodológicos sobre los que se funda la investigación. Es prioritario recordar que el capítulo 1 está compuesto por tres partes. En la primera, se abordan, desde el enfoque psicolingüístico, algunos aspectos teóricos que buscan dar cuenta de las principales posiciones teóricas y las líneas de análisis sobre la comprensión; en la segunda, realiza un acercamiento a los postulados sobre la modificabilidad cognitiva; en la tercera, se explora el cuento gráfico como texto verbovisual narrativo y multimodal. Los capítulos 1, 2 y 3 son fundamentales porque aportan las herramientas teóricas y metodológicas que permiten analizar y explicar los resultados desde lo cuantitativo y lo cualitativo, aspectos desarrollados en los capítulos 4 y 5 .

\subsection{CONSIDERACIONES METODOLÓGICAS GENERALES DE LA INVESTIGACIÓN}

Teniendo en cuenta lo expuesto, se propone una investigación de enfoque mixto de naturaleza cuasiexperimental de tipo explicativo. Se buscan las causas de los fenómenos y las condiciones de ocurrencia partiendo del análisis cualitativo y cuantitativo. En este sentido el investigador es esencial en el seguimiento de los procesos y la recopilación de la información. Además, se emplea la estrategia inductiva- descriptiva porque se recurre a la descripción del fenómeno estudiado para posteriormente buscar las respectivas explicaciones. El diseño de la investigación es preprueba, post prueba y grupo control; la prueba pretest sirve para analizar el puntaje ganancia, es decir, determinar la diferencia entre las puntuaciones de la preprueba y la 
post prueba del grupo de estudio y grupo control; además, se administran tres pruebas de monitoreo en el transcurso de la intervención al grupo de estudio para detallar sus cambios (Hernández Sampieri et al., 2010; Bono Cabré, s.f.).

\subsubsection{Hipótesis}

La hipótesis general que se propone es: La información de carácter visual resulta subsidiaria del procesamiento de la información verbal y requiere, al igual que esta última, de estrategias para su análisis. El desarrollo de estrategias específicas en el sujeto lector favorece la comprensión del texto verbovisual.

En este orden de ideas se proponen tres sub-hipótesis:

$>$ Sub-hipótesis 1. Las claves lingüísticas y las imágenes visuales son partes inseparables de un todo que da paso a procesos de comprensión integrales, complejos y flexibles propios de los textos verbovisuales narrativos.

$>$ Sub-hipótesis 2. Si se intensifica la exposición del sujeto a textos verbovisuales narrativos y participa en la aplicación de estrategias para su procesamiento, se facilitan los procesos de recuperación de conocimiento previo y su uso para la asimilación de estímulos nuevos. A mayor tiempo, frecuencia e intensidad de intervención mayor efecto en el fortalecimiento de los procesos de comprensión de textos verbovisuales.

> Sub-hipótesis 3. Los procesos de intervención para la comprensión en su gran mayoría priorizan los códigos verbales, ratificándose la tradición logocentrista y disminuyendo la variabilidad en el procesamiento textual que afecta la habilidad para realizar muestreo, producir inferencias, reflexionar y valorar la información. 
Adelantar procesos de alfabetización verbovisual proporciona beneficios derivados de la experiencia mediada que se manifiestan en el comportamiento adaptativo de los sujetos y el aumento en el grado de experticia en la comprensión.

\subsubsection{Los sujetos}

La muestra es no probabilística, su elección se da por causas relacionadas con las características de la investigación. Está conformada por 20 estudiantes $^{7}$ de tercer año de la Licenciatura en Español y Literatura de la Universidad de Córdoba, cuya edad oscila entre diecinueve y veintidós años, quienes participan de forma voluntaria y se organizan equitativamente y al azar en los grupos estudio y control. Se opta por seleccionar sujetos que comparten rangos de instrucción similares, con el fin de establecer un nivel aproximado de competencia lingüística, marcos de conocimiento y de referencia, controlando la variable interviniente. Los sujetos del grupo estudio responden la encuesta diagnóstica, resuelven las pruebas pretest, post test y monitoreos, además, asisten a 14 sesiones de trabajo de tres horas dos veces por semana en el primer semestre de 2019, intervención que se detalla en el capítulo 3. Los sujetos del grupo control únicamente solucionan las pruebas pretest y post test.

\subsubsection{La encuesta diagnóstica}

En el inicio de la ejecución de la investigación se aplica al grupo de estudio una encuesta diagnóstica (Anexo 7) compuesta por seis preguntas politómicas que pretenden caracterizar a los sujetos respecto a sus hábitos, gustos en la lectura y el

\footnotetext{
${ }^{7}$ Los sujetos firmaron el conocimiento informado para proyectos de investigación, en el cual autorizan utilizar los datos que proporcionan en la ejecución del estudio como base para la producción académica presente y futuras (Anexo 6).
} 
grado de exposición a la literatura gráfica, confirmando su nivel de estandarización como grupo. La actividad se acompaña de la socialización comentada de los resultados.

En la primera pregunta (Figura 7) los sujetos responden sobre qué hace que les guste un texto, pueden marcar más de una opción. Teniendo en cuenta la puntuación se jerarquizan las respuestas de mayor a menor de la siguiente forma: el argumento, el estilo, los personajes, la facilidad para comprender, la letra, la brevedad y el uso de imágenes. Llama la atención que el uso de imágenes obtuviese la puntuación más baja, ratificándose la primacía del código verbal sobre el pictórico.

\section{Figura 7}

¿Qué hace que le guste un texto y termine su lectura?

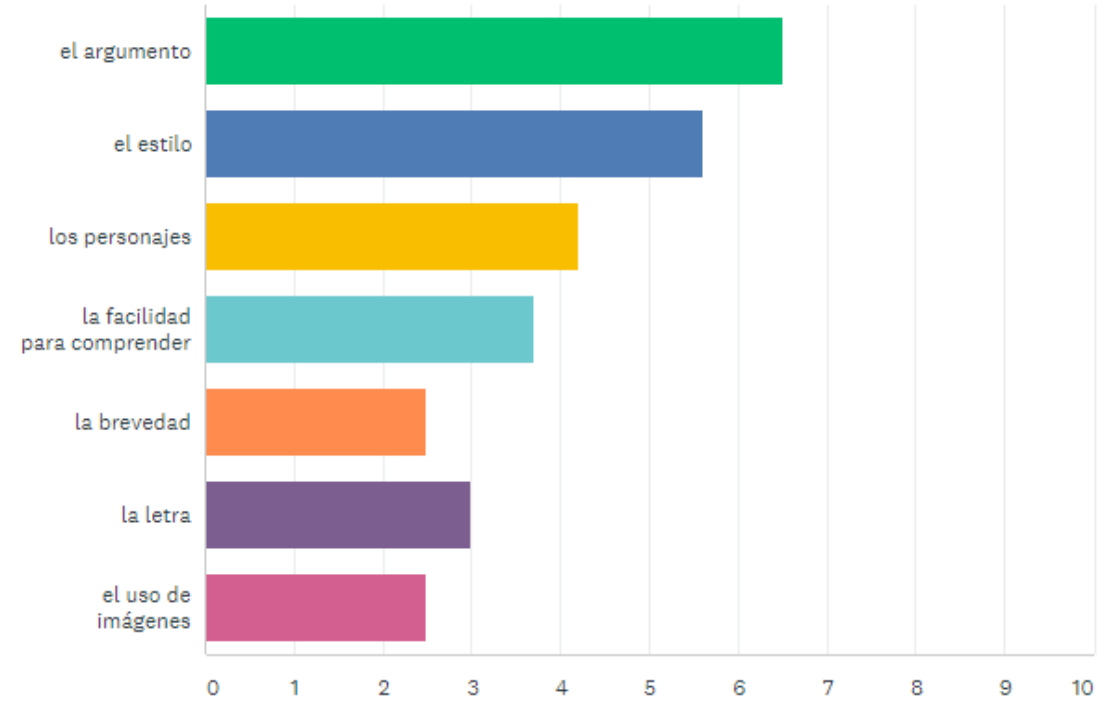

En la segunda pregunta los sujetos deben organizar los tipos de textos que leen por placer según la regularidad con la que lo hagan. En su orden responden que 
prefieren textos sobre aventuras, terror, de carácter histórico, amor, erótico, de violencia, animales y naturaleza, autoayuda (Figura 8).

\section{Figura 8}

Regularidad de lectura según la temática

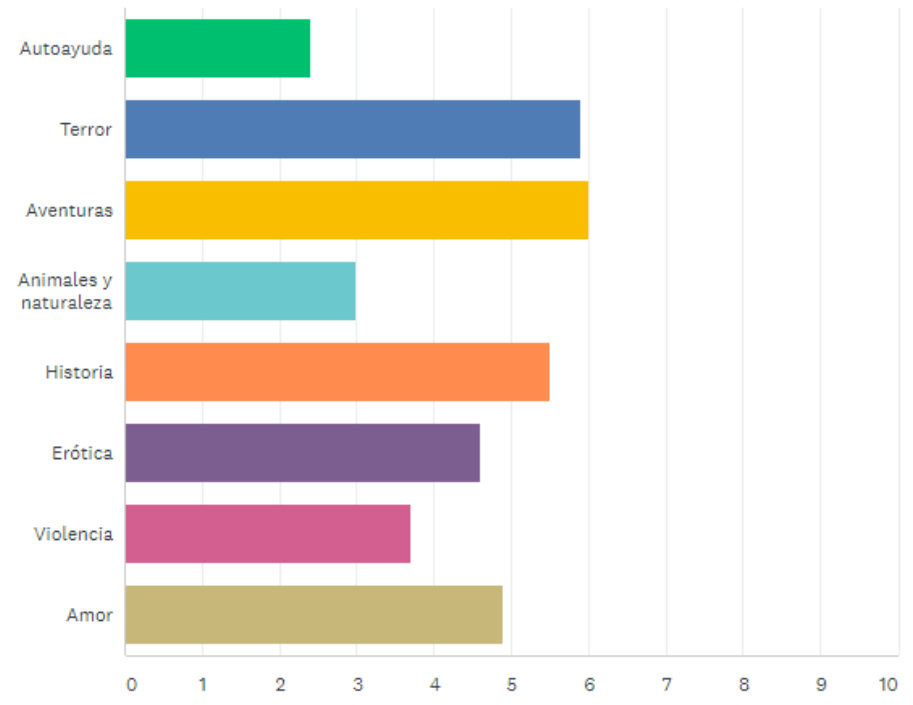

La tercera pregunta se indaga sobre cuál sería la extensión ideal para un texto que leen por placer. El 90\% de los sujetos indica que la extensión no es importante siempre y cuando sea de calidad estética y llamativo según sus gustos; mientras que para el $10 \%$ considera que entre 31 a 100 páginas sería ideal para disfrutar lo que se propone, las ideas se desarrollen sin afanes, se eviten repeticiones y dilataciones innecesarias (Figura 9). 


\section{Figura 9}

Extensión ideal para un texto

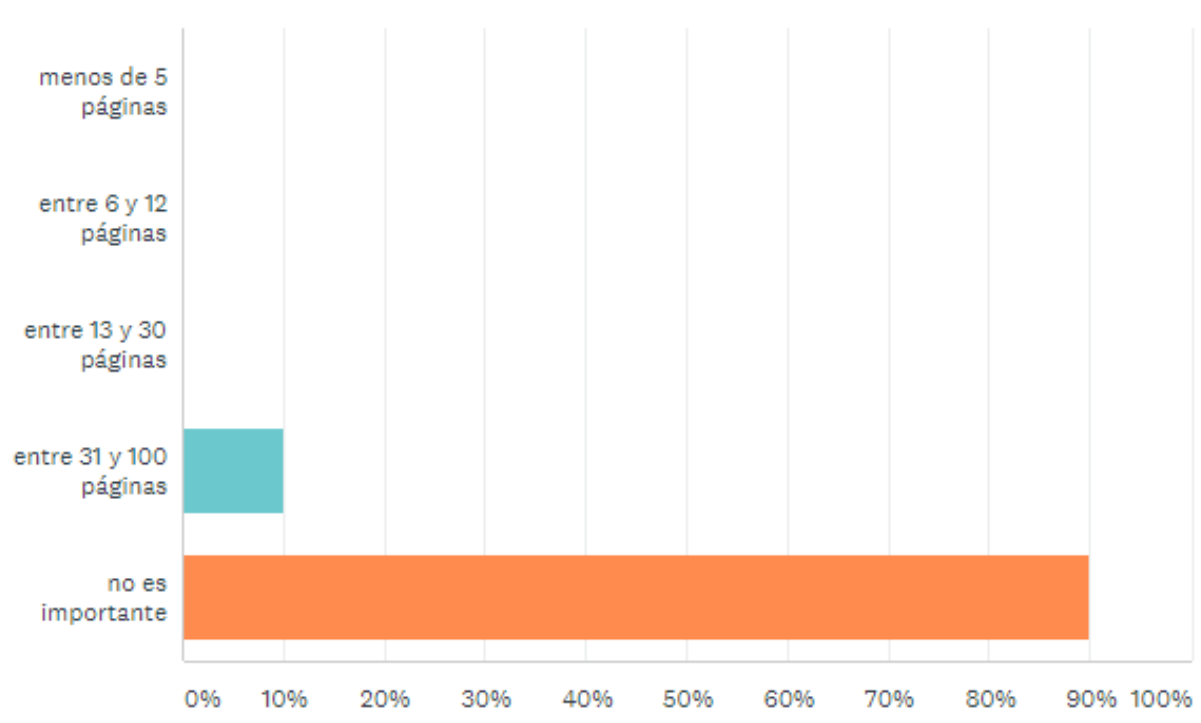

La cuarta pregunta escudriña sobre las preferencias en lectura de textos que contuviesen claves lingüísticas e imágenes visuales. El $30 \%$ de los sujetos respondieron que lo ideal es que hubiese un equilibrio entre uno y otro, mientras que para el $70 \%$ le es indiferente (Figura 10). No obstante, en la primera pregunta indicaron que el uso de imágenes en un texto es la razón menos frecuente para que les guste un texto y finalice su lectura, evidenciando confusión sobre el papel de la imagen visual en texto. 


\section{Figura 10}

Preferencias en la lectura con textos que contengan letras e imágenes.

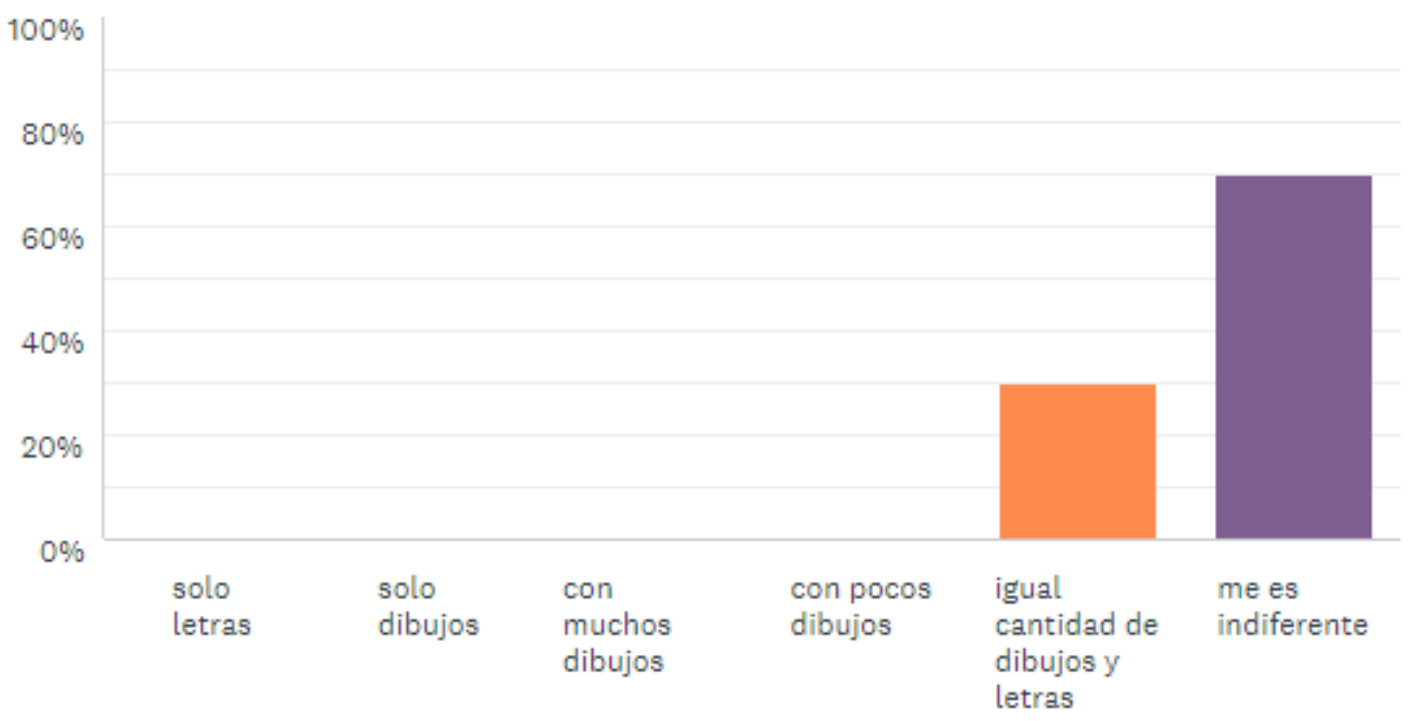

La quinta pregunta explora sobre la regularidad en la lectura de literatura gráfica, aunque es pertinente anotar que en el contexto educativo y familiar no es común su uso o presencia sea en formato digital o físico. En su orden responden que prefieren: caricaturas y humor gráfico que circulan en las redes sociales y en publicaciones seriadas como revistas o periódicos; novelas gráficas, cuentos gráficos, anime y manga que encuentran en la red de internet de forma gratuita o compran si están a bajo costo. Adicionalmente tres de los sujetos reconocen que nunca leen estos textos (Figura 11). 


\section{Figura 11}

Regularidad en la lectura de caricaturas, novela gráfica, cuento gráfico, humor gráfico, anime, manga.

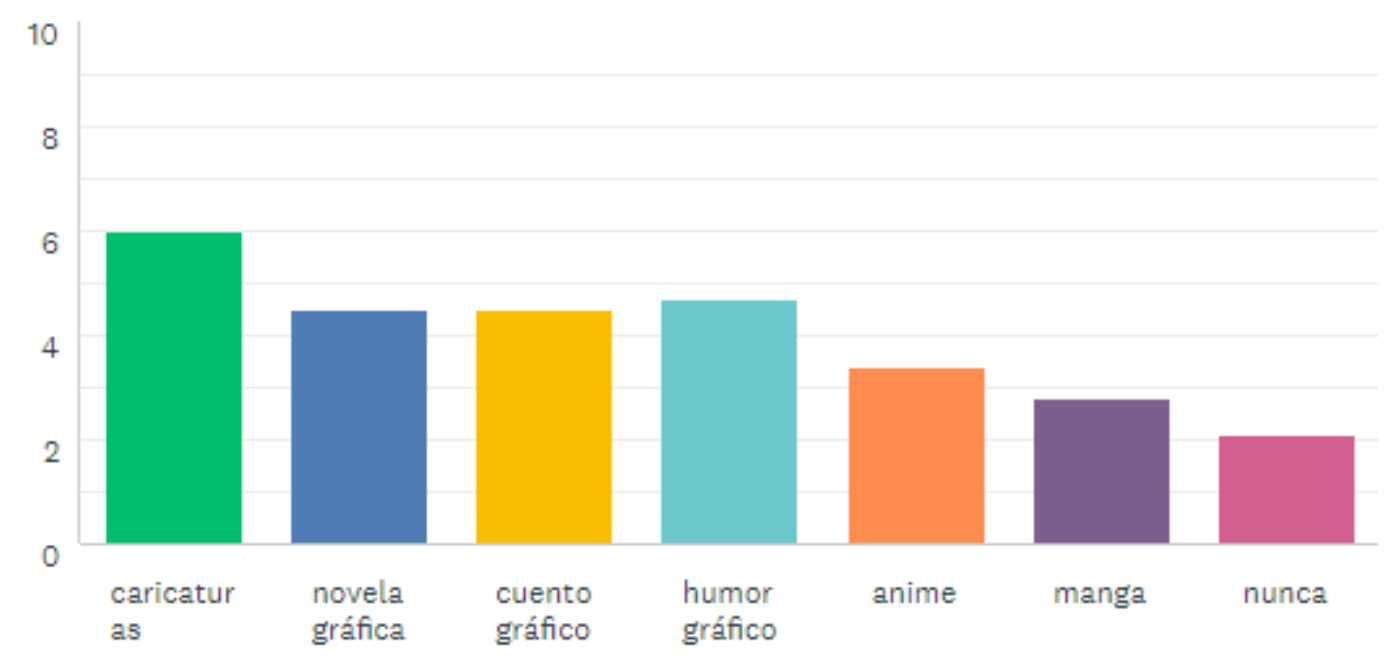

En la sexta pregunta se consulta sobre la posesión de literatura gráfica por parte de los sujetos. El $50 \%$ tiene este tipo de textos en formato digital, el $20 \%$ en formato físico y el $30 \%$ no posee estos textos en ningún formato (Figura 12).

\section{Figura 12}

Formatos en los que posee caricaturas, novela gráfica, cuento gráfico, humor gráfico, anime, manga.

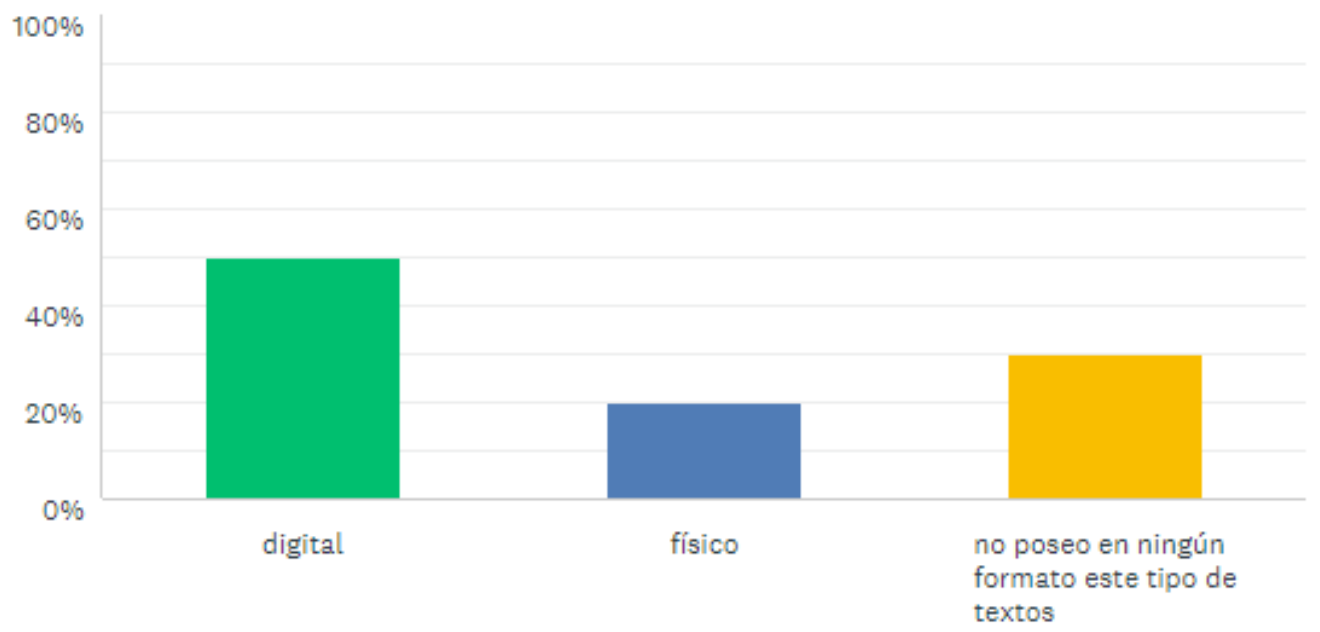


En términos generales, los sujetos del grupo estudio poseen hábitos de lectura consolidados dada la instrucción inherente a la carrera de pregrado que cursan. Sin embargo, el acceso libre y constante a los textos que les llaman la atención es restringido porque el valor de los mismos es elevado para la economía de un estudiante y no se cuentan con muchos lugares que permitan el uso libre y prolongado.

Los sujetos cuando deciden leer un texto lo hacen principalmente porque les atrae el tema, la línea argumental y el estilo. Prefieren historias que se destaquen en el arte, asociadas al terror y las aventuras, sin distinción de su extensión, con argumentos potentes, estructura narrativa y temporal compleja. Al consultarles sobre las imágenes visuales en los textos, es evidente la indiferencia hacia ellas porque casi nunca es objeto de reflexión y análisis en ningún contexto en los que participan. La literatura gráfica no se lee frecuentemente, aunque les es llamativa. Por tanto, el grupo estudio posee poco conocimiento previo sobre este tipo de literatura y el grado de exposición es escaso.

Teniendo en cuenta lo descrito se puede afirmar que los sujetos han trabajado de forma permanente en el mejoramiento de sus procesos de comprensión de textos verbales pero no de textos visuales o verbovisuales; el conocimiento previo que tienen de la literatura gráfica es casi nulo; y el grado de exposición es igualmente mínimo porque el contexto comercial, cultural y académico no lo favorece. En consecuencia, no presenta diferencias significativas, constituyéndose en un grupo estandarizado.

Adicionalmente, las respuestas resultan efectivas para la confirmación de los cuentos gráficos que se emplean en el transcurso de la intervención. 


\subsubsection{Las variables}

Las variables propuestas para el estudio son independiente, dependiente e interviniente (Tabla 2). La primera, corresponde al procesamiento de la información textual en textos verbovisuales narrativos, específicamente el cuento gráfico, centrándose en el rastreo del comportamiento de la imagen visual y las claves lingüísticas. La segunda, consiste en la modificabilidad en la comprensión como proceso cognitivo que implica la recuperación de la información, la producción de inferencias, la reflexión y la evaluación de la información. La tercera, apunta al conocimiento previo y el grado de exposición a los textos mencionados, que permite la selección u omisión de información textual y enciclopédica.

La variable independiente es la causa, corresponde a la intervención y se controla al generar una situación de aprendizaje mediado que posibilita explicar cómo se afecta y mide la variable dependiente. Es decir, el estímulo o tratamiento experimental conlleva a las operaciones experimentales. En la operacionalización de variables se definen las acciones que se realizan para transferir el concepto teórico a uso práctico (Hernández Sampieri et al., 2010).

\section{Tabla 2}

Operacionalización de variables

\begin{tabular}{|c|c|}
\hline VARIABLE & INDICADORES \\
\hline Dependiente: & Recuperación de la información (muestro) \\
\hline \multirow[t]{2}{*}{$\begin{array}{l}\text { Modificabilidad en la } \\
\text { comprensión }\end{array}$} & $\begin{array}{l}\text { Producción de inferencias (Predicción, anticipación, confirmación y } \\
\text { autocorrección) }\end{array}$ \\
\hline & Reflexión y evaluación de la información \\
\hline
\end{tabular}


Independiente:

Intervención verbovisual

Interviniente:

Conocimiento previo y grado Selección u omisión de información textual y enciclopédica.
Reconocimiento y análisis de los aspectos denotativos, connotativos y conceptuales de la imagen visual.

Reconocimiento y análisis de los aspectos microestructurales, superestructurales, macroestructurales en los textos partiendo de las claves lingüísticas. de exposición

Fuente: elaboración propia

\subsubsection{El estudio de caso y la triangulación}

Merrian (1998) indica que en la investigación cualitativa prevalecen los siguientes métodos: estudios cualitativos básicos o genéricos, etnografía, fenomenología, teoría fundamentada y estudio de casos. En la presente tesis se emplea el último.

El estudio de casos se utiliza para analizar en profundidad la comprensión de un fenómeno conservando la visión total, donde las acciones planeadas recaen sobre el proceso más que en el resultado, se busca realizar descripciones y análisis intensivos. La unidad de análisis es el caso, definido este último como un sistema delimitado, integrado, simple que tiene lugar en un contexto específico. Se caracteriza por tratar de interpretar un fenómeno en el contexto en el que tiene lugar, enfocándose en descripciones y explicaciones holísticas, es decir, se reconoce que para la interpretación del fenómeno es necesario vincular permanentemente cada una de las fuentes de información como insumos y perspectivas diferentes del proceso, lo anterior 
permite dar cuenta del cómo y por qué, descubriendo vínculos entre las variables y la relación a la teoría.

Piovani et al. (2011) afirman que un caso puede ser asumido como una elección de objeto de estudio por su especificidad o como una opción metodológica puesto que se instituye como un medio para la comprensión de un problema. En el presente estudio se decide por la segunda, es decir, se asume el caso desde su perspectiva instrumental (Stake, 2003) porque se concibe como un medio de descubrimiento y desarrollo de proposiciones empíricas de carácter más general que el caso mismo, el caso es un medio y no un objeto de estudio (Gundermann, 2004); además, permite proveer conjeturas en torno de un problema y reflexionar sobre una teoría de tal forma que se obtenga una mayor claridad. El caso es un instrumento para conseguir otros fines indagatorios.

En la investigación que se comparte, el interés es analizar en profundidad la comprensión de textos verbovisuales narrativos, las acciones planeadas recaen sobre el proceso desarrollado por los estudiantes más que en los resultados de las actividades que resuelven. Por lo anterior, se realizan descripciones y análisis intensivos de los desempeños de la población participante a partir de la información recolectada en la intervención. Se emplea el estudio de casos psicológico porque particulariza y permite estudiar a detalle el fenómeno en un tiempo determinado concentrándose en los desempeños de los sujetos. Además, es descriptivo e interpretativo, el primero porque da cuenta del fenómeno que se estudia; el segundo porque los datos descriptivos se utilizan para desarrollar y respaldar categorías conceptuales (Ragin, 2000). 
Según Stake (1998) en un caso el interés radica en saber qué es y qué se hace, se pregunta cómo y por qué sucede un fenómeno, no se controlan los eventos. No hay intenciones de realizar generalización en el sentido estadístico, no se definen leyes generales, pero los resultados y las interpretaciones que se construyen pueden ser suficientes para generar ideas y opciones para diferentes escenarios. Existe el privilegio y la responsabilidad de la interpretación que implica no intervenir para que los datos sean fidedignos. Para cerciorarse de la confiabilidad Stake recomienda la triangulación (Arzaluz, 2005). Esta última corresponde al uso de varios métodos al estudiar un mismo fenómeno. Al respecto, Bonache (1999) citando a Yin afirma que “[...] una investigación empírica estudia un fenómeno contemporáneo dentro de su contexto real, cuando las fronteras entre el fenómeno y el contexto no son evidentes, y en la que se utilicen múltiples fuentes de evidencias (Yin, 1989)”. (p. 124)

La triangulación permite alcanzar precisión, contar con caminos alternativos y estrategias que no dependen de la intuición. Al respecto Gundermann (2004) afirma que:

[...] lo que haría específico un estudio de casos más que radicar en una forma especial de reunir información y sistematizarla con fines de investigación social, es mantener la unidad que está siendo estudiada (un individuo, una organización, una cultura, etc.) (Goode y Halt, 1969); el estudio de caso es el estudio de lo particular (Stake, 1994). (p. 256)

Por tanto, con la triangulación se puede encontrar el mismo resultado en diferentes fuentes y circunstancias, de tal forma que se aumentan las fortalezas y la calidad del estudio, debido a que se produce información redundante, esclarecen 
significados y verifica repetitividad, en otras palabras, se emplean diferentes métodos para visualizar un fenómeno ampliamente y se evita las fallas metodológicas (Flyvbjerg, 2004).

Al emplear la triangulación se busca disminuir las debilidades de cada método e incrementar las fortalezas. No obstante, si se emplean un único método es probable que se puedan presentar sesgos en la información recolectada y en la interpretación. Por otra parte, si se recurre a varios métodos permitiría abordar el interés investigativo desde varios puntos de vista, aumentar la validez, confirmar los datos, aportar mayor confiabilidad y precisión de resultados demostrables. En otras palabras, obliga a hacer una continua revisión, incrementa las fortalezas y la calidad del estudio por lo que en la recolección de la información se emplean los siguientes instrumentos: registro de actividad, encuestas, entrevistas, observación directa y análisis de resultados de ejercicios.

En la presente investigación se utiliza la triangulación de metodología. Es decir, se usan diferentes métodos (cualitativos y cuantitativos) y fuentes de datos que permiten la recolección y el análisis de la información (entrevistas, encuestas, observaciones). Con la triangulación se pueden contrastar los resultados, determinar coincidencias y diferencias dadas las similares aproximaciones que se obtienen del fenómeno de estudio. De tal forma que se asegura la confiabilidad de los resultados en función de los tiempos, los recursos y los propósitos a través del seguimiento al protocolo de intervención, la fidelidad y la recolección de la información que se registra en las bases de datos (Yin, 2009). Lo anterior es representativo teniendo en cuenta la posición de Gundermann (2004) quien citando a Mitchell expresa que “... inferimos que 
las características presentes en el estudio de casos pueden ser relacionadas a una población mayor no porque el caso es representativo, sino porque nuestro análisis es irrebatible $(1983,200) " .($ p. 271)

\subsection{CONSIDERACIONES METODOLÓGICAS PSICOLINGÜÍSTICAS}

Los lectores se enfrentan a caudales de informaciones que procesan de forma estratégica para economizar procesos cognitivos y ocupar la memoria con datos absolutamente necesarios. En tal procesamiento, la comprensión permite transformar los textos en unidades de sentido susceptibles de archivarse de forma temporal o indefinida. Desde esta perspectiva, la comprensión se asume como el resultado de una construcción activa del significado de la información disponible en el texto y del conocimiento previo del lector integrado a la situación comunicativa; lo que explicaría por qué la forma superficial del texto resulta irrelevante para la mayor parte de los lectores y la forma profunda o contenido subyacente es crucial, de ahí que sea esta última la que se recuerda posteriormente. Asimismo, se realizan subprocesos de adecuación entre lo dicho y lo no dicho, el fragmento de lengua y la competencia lingüística, la información textual y la competencia comunicativa y pragmática, relaciones imposibles sin la intervención de inferencias de múltiples tipos. Lo expuesto corrobora que sin inferencias no hay compresión, éstas son la base para el desciframiento de los códigos escritos u orales y la integración de la información textual con el conocimiento previo (León, 2001 y 2003; Valle et al., 1990; Valle, 1992; De Vega, 1984 y 1990). 
El aprendizaje de la comprensión es convencional. Leer no implica comprender, se necesita disposición del que lee y apoyo pedagógico. Leer es el resultado de la relación entre conocimiento y experiencias previas, competencia lingüística, información del texto e información del contexto, esquemas (estructuras cognitivas existentes) y modelos mentales (resultado de la relación entre ideas). En Colombia, en las últimas décadas para abordar este asunto se han diseñado programas y documentos de apoyo enfocados en la comprensión de textos escritos, dejando de lado las imágenes que inundan los diferentes contextos en los que participan los estudiantes. Desde los entes gubernamentales se proyectan y se aplican pruebas externas utilizando textos verbovisuales, asumiendo que los evaluados encontrarían ventajas textuales, ocurriendo lo contrario. Si bien las imágenes operan, en muchos casos, como facilitadoras del procesamiento de la información de carácter verbal, también requieren de estrategias para su abordaje y la aplicación de actividades que potencien la comprensión de este tipo de textos (León, 2001 y 2003).

Igualmente, el género del texto influye en los procesos de comprensión debido a que se ponen en juego una serie de factores pragmáticos que hacen que el lector deba utilizar estrategias específicas para cada género, contenidos y propósitos de lectura. Un tipo de texto puede propiciar reproducción de contenidos básicos, generación de preguntas, elaboración de juicios racionales, reacción emocional, evaluaciones, asociaciones, comparaciones, jerarquizaciones y síntesis. En el panorama de las investigaciones psicolingüísticas se ha privilegiado el estudio de textos narrativos verbales, por ello, se propone trabajar con textos verbovisuales narrativos, específicamente los cuentos gráficos (León, 2001; León et al., 2003). 
El método experimental más usado en los estudios sobre comprensión es el análisis del discurso escrito. En éste es más fácil estructurar y controlar las variables que afectan su procesamiento. Valle (1992) afirma que:

Mientras en la comprensión el experimentador puede controlar el "input" construyendo determinadas oraciones o textos que cumplan ciertos requisitos [...] y ver el efecto que de tales variables producen en la comprensión, en la producción tal control es imposible o, en todo caso, indirecto. (p. 102)

El texto escrito es un medio permanente, bidimensional y perceptible, "[...] es un patrón de formas visuales" (De Vega y Cuetos, 1991, p. 25). El autor distribuye una cierta cantidad de palabras organizadas según las normas del sistema de la lengua en uso y sus propósitos. Por su parte, el lector identifica intenciones y construye la macroestructura textual por medio del establecimiento de las relaciones entre la cantidad de información presentada, las estructuras intrínsecas de la información y las limitaciones espaciales; así, mientras lee, construye un texto paralelo y relacionado con el texto original.

La interacción del lector con el texto que comprende lo puede conducir a procesos de producción orales o escritos. Para efectos de la investigación es de interés la escritura como testimonio de procesos de comprensión. En este sentido, se debe considerar que al escritor lo guía una intención comunicativa, activa conocimientos, acude a su competencia comunicativa y lingüística para codificar eficientemente el mensaje, selecciona en su léxico mental las palabras que encajan en la estructura construida para expresar el significado. En otras palabras, “[...] la comprensión realimenta al sistema de producción del lenguaje; mientras que la comprensión no tiene 
una realimentación equivalente: comprendemos sin reproducir lo que comprendemos" (De Vega y Cuetos, 1991, p. 27).

\subsubsection{Métodos de la psicolingüística}

En la investigación psicolingüística el método corresponde al camino sistemático direccionado a un resultado, tiene su asidero en la teoría y la epistemología de la disciplina. Permite examinar los procesos automáticos y controlados vinculados al comportamiento verbal que no son detectados de forma consciente o directa por el sujeto. Las técnicas son los conjuntos de procedimientos que permiten la instrumentalización del método (De Vega y Cuetos, 1999). En marco del presente estudio se emplean los siguientes métodos y técnicas (se ampliará en el capítulo 3).

$>$ El método observacional o descriptivo. No se encuentra condicionado por el investigador y se tiene menos control experimental de los estímulos. En toda la intervención se usa para recolectar información y examinar la conducta lingüística tal y como ocurre en las actividades verbales de comprensión.

$>$ El método conductual. Se mide, registra y analiza la conducta lingüística de los sujetos en condiciones controladas de experimentación. A su vez, se recurre a las técnicas a posteriori u off-line y en curso u on-line. En las primeras, se proporcionan los textos sin intervenir ni registrar ningún dato sobre el proceso, para luego recolectar sus respuestas; se promueve el recuerdo libre o la recuperación de información guiado a partir de preguntas; para ello, se aplican cinco pruebas de comprensión y ejercicios del club de lectura. En las segundas, se inmiscuye en el proceso y se registra, se siguen los mecanismos puestos en 
juego de forma simultánea; tal es el caso de los ejercicios cognitivos y los juegos de estrategia.

\subsection{RECAPITULACIÓN}

El enfoque metodológico es mixto, estudio explicativo, de diseño cuasiexperimental (Bono Cabré, s.f.). Se asume el estudio de caso desde su perspectiva instrumental (Stake, 2003) porque se concibe como un medio de descubrimiento y desarrollo de proposiciones empíricas de carácter más general que el caso mismo, el caso es un medio y no un objeto de estudio (Gundermann, 2004); además, permite proveer conjeturas en torno de un problema y reflexionar sobre una teoría de tal forma que se obtenga una mayor claridad. El caso es un instrumento para conseguir otros fines indagatorios. El interés es analizar en profundidad la comprensión de textos verbovisuales narrativos, las acciones planeadas recaen sobre el proceso desarrollado por los sujetos más que en los resultados de las actividades que resuelven.

Por otra parte, se utiliza la triangulación de metodología. Es decir, se usan diferentes métodos (cualitativos y cuantitativos) y fuentes de datos que permiten la recolección y el análisis de la información (entrevistas, encuestas, observaciones). De tal forma que se asegura la confiabilidad de los resultados en función de los tiempos, los recursos y los propósitos a través del seguimiento al protocolo de intervención, la fidelidad y la recolección de la información que se registra en las bases de datos. 
CAPÍTULO 3

PROTOCOLO DE

INTERVENCIÓN 


\subsection{INTRODUCCIÓN}

El protocolo de intervención es la planeación del estudio de caso en relación con los tiempos, los recursos y los propósitos de la investigación Las claves lingüísticas y la imagen visual en la comprensión de textos verbovisuales narrativos: cuentos gráficos. Se parte de la premisa de que la comprensión del texto verbovisual narrativo requiere de entrenamiento. Si bien las imágenes operan, en muchos casos, como facilitadoras del procesamiento de la información de carácter verbal, también requieren de estrategias para su abordaje y la aplicación de actividades que potencien la comprensión de este tipo de textos.

En este sentido, los objetivos que se proponen para la intervención son: exponer a los participantes al procesamiento de cuentos gráficos para incrementar la cantidad de información textual disponible (conocimiento previo verbal y visual); proporcionar mayores recursos para procesar la información y construir las inferencias necesarias para alcanzar la comprensión local y global del texto; analizar lo que hacen a los sujetos cuando comprenden textos verbovisuales narrativos; caracterizar el tipo de alfabetización necesaria para fortalecer la comprensión de textos verbovisuales. Es decir, se diseña una experiencia de aprendizaje mediado en la que se aplican una serie de instrumentos en los que se manipula la información textual (claves lingüísticas e imágenes visuales) y se hace un seguimiento riguroso a la administración de tareas, lo cual tendrá un efecto sobre la comprensión.

Así mismo, se remarca que desde la modificabilidad cognitiva se reconoce que se pueden causar cambios estructurales provocados en los organismos gracias a programas deliberados de intervención para facilitar un crecimiento continuo de las 
capacidades perceptivas, cambios que afectan a los sujetos. Entonces, se propone una interacción entre el sujeto y el entorno, que provoca la exposición directa a los estímulos y el incremento de experiencias de aprendizaje mediatizado por un agente. Se busca enriquecer y desarrollar los procesos cognitivos básicos a través de la aplicación y el ejercicio de estrategias solucionadoras de problemas; se busca dominio y comprensión de sus propios procesos (Feuerstein et al., 1991).

\subsection{MÓDULOS DE TRABAJO}

La intervención tiene como finalidad favorecer la comprensión de textos verbovisuales a partir del uso de pruebas de lectura, actividades desestructurantes, club de lectura, juegos cognitivos de estrategias, solución de ejercicios cognitivos, fundamentación teórica sobre imagen visual. Para la recolección de la información de cada sesión se emplea el diario de campo, en él se registran las observaciones e interpretaciones pertinentes. El proceso de evaluación se basa en la retroalimentación de cada una de las actividades. Se diseña la intervención en cuatro módulos, tal como se muestra en la tabla 3.

\section{Tabla 3}

Estructura de los módulos de trabajo

\begin{tabular}{|c|c|}
\hline PARTE & CONTENIDO \\
\hline $\begin{array}{l}\text { MÓDULO 1. Cuentos } \\
\text { gráficos }\end{array}$ & $\begin{array}{l}\text { Prueba pretest: } \\
\text { El testamento del señor Morris. Dibujo y guion de Joan Boix } \\
\text { Pruebas de monitoreo: } \\
>\quad \text { El secreto de la cañada de Macarger. Basado en un cuento de Ambrose } \\
\text { Bierce, adaptación y dibujos de Horacio Lalia }\end{array}$ \\
\hline
\end{tabular}


$>$ El mal. Dibujo y guion de Joan Boix.

$>$ El estúpido humano. Dibujo y guion de Joan Boix.

\section{Prueba post test:}

$>$ La fobia. Basado en el cuento El Perro de Hudson Irish, dibujo y guion de Joan Boix.

Cuentos para actividades desestructurantes en las diferentes sesiones:

$>$ Arthur Jermyn. H.P. Lovecraft

> Estirpe de la cripta. Cuento de Ashton Smith, adaptación y dibujos de Horacio Lalia.

$>$ La casa sola. Cuento de Bretón, adaptación y dibujos de Horacio Lalia.

$>$ La música de Erich Zann. H.P. Lovecraft.

$>$ ¿Qué era aquello? Inspirado en un relato de Fitz-James O’Brien, dibujo y guion de Joan Boix.

> Fantasma, episodio completo. Guión Jorge Mora, dibujo Breccia.

Club de lectura a partir de los siguientes textos:

$>$ Hostil y abyecto. Fernando Baldó.

$>$ Los gritos del pasado. Léonie Bischoff y Oliver Bocquet.

$>$ Las aventuras de Tintín en América. Hergé

$>$ Lo mejor de Poe. Edu Molina.

> El corazón de las tinieblas. Basado en una historia de Joseph Conrad, versión gráfica de Jorge Morhain, Martín Túnica y Pablo Túnica.

$>$ El retrato de Dorian Gray. Inspirado en la historia de Oscar Wilde, versión gráfica de Jorge Morhain, Martín Túnica y Pablo Túnica.

$>$ El mago de Oz. Frank Baum, versión gráfica de Martin Powell y Jorge Break.

$>$ Corto Maltés. Hugo Pratt.

$>$ Toda Mafalda. Quino.

$>$ Don Abundio \#1. Frank Ridgeway.

$>$ Lo mejor de Carlitos y Snoopy. Charles Schulz.

$>$ Don. Henry \#6 y \#8. Don Trachte.

$>$ Teseo y el minotauro. Nel Yomtov y Tod Smith.

$>$ Veneno. Peer Meter y Barbara Yelin.

MÓDULO 2.

50 ejercicios cognitivos para fortalecer la percepción, la atención, la Ejercicios cognitivos concentración y la memoria. 


\section{MÓDULO 3. Juegos \\ de estrategia}

MÓDULO 4.

Fundamentación

sobre la imagen

visual
Nueve juegos de estrategia que permiten:

1. Fortalecer los procesos cognitivos básicos

2. Emplear operaciones mentales como observar, preguntar, superponer, detallar, comparar, resaltar, abreviar, globalizar, deducir, sintetizar, reducir, organizar, prever, relacionar, descubrir elementos comunes, discriminar, asociar, abstraer, imaginar, estructurar, añadir.

3. Razonar de forma hipotética, transitiva, analógica, lógica, silogística, inferencial.

\section{ANÁLISIS DE LA INFORMACIÓN TEXTUAL}

Análisis objetivo, denotativo o formal:

1. Elementos escalares: tamaño, espacio

2. Elementos morfológicos: punto, línea, color, luz, contraste, textura, forma

3. Elementos dinámicos: composición, ritmo, encuadre, angulación, planos, profundidad, gutter.

Análisis connotativo o subjetivo (creencias, conocimientos y estados anímicos):

1. Intención del autor

2. Público del texto

3. Funciones y objetivos de la imagen

4. Anclaje de la imagen en el contexto

5. Estereotipo, prejuicios, discriminación

Análisis conceptual (función o acción de los elementos de una imagen)

1. Función o acción de los elementos de una imagen (descriptiva, informativa, estética, expresiva, sugestiva).

2. Anclaje de la imagen en el contexto: ¿qué función cumple?, ¿a quién va dirigida?, ¿en qué contexto social, político o económico se sitúa?, ¿cuál es el significado final que el autor nos quiere comunicar?

3. Nivel de representación (iconicidad), modos de expresión según la época.

Fuente: Elaboración propia 


\subsubsection{Módulo 1. Cuentos gráficos ${ }^{8}$}

Los cuentos gráficos se emplean en tres sentidos: primero, para las pruebas de comprensión; segundo, para la lectura independiente de literatura gráfica como biblioteca itinerante y excusa para la discusión empleando la estrategia de club de lectura; tercero, en las actividades desestructurantes de análisis y debate abierto. Para la selección de los cuentos se tienen en cuenta las siguientes restricciones:

1. Poseer imagen visual y claves lingüísticas en igualdad de aparición para que exista equilibrio; entre los códigos icónicos y verbales deben presentarse relaciones de alusión, complementariedad, interdependencia, simetría y redundancia. Se asegura la igualdad en sus relaciones cuantitativas.

2. Estar dibujados a blanco y negro.

3. Ser textos desconocidos para los sujetos, de lo contrario se contaminarían las respuestas dado que no sería la primera vez en enfrentarse a su procesamiento.

4. Versar de temáticas atemporales.

5. Estar escritos en español, para evitar dificultades con aspectos asociados al bilingüismo, segunda lengua, lengua extranjera, contacto lingüístico. Temas ajenos a los investigados.

6. Ser llamativos y desafiantes para los sujetos.

7. Entrañar cierta complejidad en su línea argumental.

\footnotetext{
${ }^{8}$ Es preciso resaltar que los cuentos gráficos empleados se recolectan de diferentes colecciones de libros dedicadas a este tipo de textos, su uso es exclusivamente con fines investigativos. La autora se ampara en la Ley 23 de 1982 Sobre derechos de autor que en su artículo 32 reza: "Es permitido utilizar obras literarias o artísticas o parte de ellas, a título de ilustración en obras destinadas a la enseñanza, por medio de publicaciones, emisiones de radiodifusión o grabaciones sonoras o visuales, dentro de los límites justificados por el fin propuesto, o comunicar con propósitos de enseñanza la obra radiodifundida para fines escolares, educativos, universitarios y de formación profesional sin fines de lucro, con la obligación de mencionar el nombre del autor y el título de las obras así utilizada." (Congreso de la República de Colombia, 1982, p. 23)
} 
8. No exceder las 10 páginas. Así se asegura el mantenimiento de la curva atencional y su lectura en los tiempos proyectados.

Ahora bien, los cuentos gráficos convencionales (Boix, 2009; Lalia, 2008a; Lalia, 2008b, Oesterheld y Breccia, 2013) son la base para el diseño y la aplicación de la prueba pretest, los tres monitoreos y la prueba post test (Anexos 1, 2, 3, 4, 5), conformadas por 10 preguntas cerradas de selección múltiple con única respuesta. La prueba pretest se aplica en la primera sesión para identificar el nivel de comprensión de los sujetos y para tener una referencia de comparación respecto a la prueba final. Las pruebas dos, tres y cuatro se emplean para monitorear el avance de los sujetos y para que se familiaricen con el tipo de texto y de prueba. La prueba post test se utiliza para analizar el progreso en el nivel de comprensión en relación con la prueba pretest, permite establecer si las decisiones metodológicas de la intervención fueron acertadas o no. Las pruebas buscan que el lector elabore y explicite la representación semánticapragmática del texto sin inhibición o focalización. Por tanto, a partir de la información textual disponible, los sujetos desarrollan su plan personal de procesamiento (recoger, organizar, almacenar). Lo expuesto permite identificar los focos discursivos, la primacía o la igualdad de las claves lingüísticas y la imagen visual.

Es pertinente agregar que después de la ejecución de las pruebas se abre un espacio para la reflexión sobre qué hacen los sujetos para comprender, para ello, se les formulan las siguientes preguntas detonadoras: ¿dónde consiguen la información que le permite resolver las preguntas?, ¿qué le ayuda a responder cada pregunta?, ¿qué debe hacer para responder cada pregunta?, ¿por qué descartan las opciones que consideran incorrectas?, ¿qué palabras e imágenes son esenciales para comprender el 
cuento?, ¿cuál es la idea central del texto, en qué parte aparece o la construye?, ¿qué sucede en el texto, por qué y cómo?, ¿cómo está organizado el texto, cómo se presenta la información?, ¿cuál información sirve para comprender el texto?.

De Vega y Cuetos (1991) resaltan que en los experimentos proyectados para replicar contextos naturales y ligados a procesos de comprensión que se evidencian en la producción es:

[...] el sujeto -no el experimentador- el que decide qué es lo que va a decir o escribir y en qué forma. Es así porque el input es externo en la comprensión, mientras que es interno en la producción; exactamente lo contrario que el output, que es interno en la comprensión y externo en la producción. (p. 27) Lo anterior, acarrear sesgo en la medición de las respuestas, puesto que el sujeto no dice siempre la verdad, pueda que no comprenda, olvide con facilidad o agregue información para impresionar al experimentador (Lohr, 2000). Para contrarrestar el sesgo de medición se repiten cinco veces las pruebas de comprensión de textos verbovisuales (Anexos 1, 2, 3, 4, 5). De esta forma se logra un anticipo de los resultados, que sirven de escala de comparación para evaluar la distribución de los datos según las variables y la validez externa de la prueba definitiva; y los cambios observados pueden atribuirse a la manipulación experimental y la comparación de los grupos, es decir, validez interna (Pascual et al., 1996).

Adicionalmente, con el fin de incrementar el conocimiento previo y el grado de exposición de los sujetos a los cuentos gráficos, en el desarrollo de la intervención se le proporcionan otros títulos de este tipo de textos, los cuales leen voluntariamente en sus tiempos libres. Utilizando la estrategia del club de lectura, se abordan los cuentos 
gráficos en tres frentes: en el primero se explora el placer de la lectura, el impacto emocional en el lector y las relaciones intertextuales; en el segundo, se aprecia el valor estético de la obra literaria verbovisual y se analizan los elementos denotativos y connotativos de la imagen visual; en el tercero, se reflexiona sobre la forma cómo hicieron el muestreo, las predicciones, las anticipaciones, las confirmaciones y las autocorrecciones a partir de los textos. En esta oportunidad los cuentos empleados son: Hostil y abyecto de Baldó (2016), Los gritos del pasado de Bischoff y Bocquet (2015), Las aventuras de Tintín en América de Hergé (2012), Lo mejor de Poe de Molina (2014), El corazón de las tinieblas de Joseph Conrad, versión gráfica de Morhain et al. (2016), El retrato de Dorian Gray de Oscar Wilde, versión gráfica de Morhain et al.(2015), El mago de Oz de Frank Baum, versión gráfica de Powell y Break (2017), Corto Maltés de Pratt (2003), Toda Mafalda de Quino (2010), Don Abundio \#1 de Ridgeway (1987), Lo mejor de Carlitos y Snoopy de Schulz (2012), Don. Henry \#6 y \#8 de Trachte (1987), Teseo y el minotauro de Yomtov y Smith (2011), Veneno de Meter y Yelin (2010).

El uso de los cuentos gráficos en las pruebas de comprensión y en el club de lectura permite recoger información sobre cómo se procesan textos verbovisuales e incita a que los sujetos se percaten de las acciones cognitivas puestas en marcha y asociadas a la comprensión gracias a la identificación de cómo realizan el muestreo, la predicción, la anticipación, la confirmación y la autocorrección. De tal forma que se promueve el traspaso paulatino de la responsabilidad y la conquista de la autorregulación a partir del autoconocimiento de lo que se hace mientras se comprende. 
Los cuentos gráficos se aprovechan como base para el desarrollo de actividades desestructurantes, pensadas para incitar a los sujetos a leer y comprender mediante la descomposición de los elementos y las relaciones de la infraestructura de los textos verbovisuales narrativos. Se acentúa el análisis y el debate de forma individual y en grupos. Se detallan seguidamente:

> Actividad desestructurante 1. El cuento gráfico Estirpe de la cripta (Lalia, 2008b) se lee por parte de los sujetos, luego se les solicita que realicen una representación simbólica. Finalmente se socializan las decisiones.

D Actividad desestructurante 2. Los 10 sujetos se organizan en dos grupos, se les entrega el cuento La música de Erich Zann (Corben, 2016). Al grupo A se le proporciona una versión que solo contiene imágenes visuales y al grupo B solo claves lingüísticas, deben intentar comprenderlo teniendo en cuenta la información disponible. Después se les entrega la versión original para que la lean y respondan: ¿qué tan cercana está su interpretación de la versión asignada a la original?, ¿qué les permite acercarse o alejarse?, ¿coinciden las ideas globales del cuento gráfico en cada una de las versiones?, ¿cómo ayuda u obstaculiza la imagen visual y las claves lingüísticas en el proceso?, ¿qué información se prioriza en cada caso y por qué? Cada grupo socializa sus respuestas y se realiza un debate.

Actividad desestructurante 3. Los sujetos se organizan en tres grupos y se les entrega el cuento gráfico Fantasma, episodio completo (Oesterheld y Breccia, 2013) en las siguientes versiones: grupo A con las viñetas recortadas y en desorden correspondientes al clímax y el final; grupo B con las viñetas 
recortadas y en desorden correspondientes al inicio y el final; grupo $\mathrm{C}$ con las viñetas recortadas y en desorden correspondientes inicio y clímax. Deben organizar las viñetas, intentar descubrir qué parte les falta y qué pasó en ella. Después leen la versión original. Cada grupo responde: ¿qué tan cercana está su interpretación de la versión original?, ¿qué les permite acercarse o alejarse?, ¿a pesar de faltarles una parte de la narración pueden construir la idea global del cuento gráfico?, ¿cómo lo hacen?, ¿qué utilizan?, ¿cómo ayuda u obstaculiza la imagen visual y las claves lingüísticas en el proceso?, ¿qué información se prioriza y por qué?

Actividad desestructurante 4. A los sujetos se les entrega el cuento gráfico La casa sola (Lalia, 2008b). Se solicita que mientras leen encierren en un círculo de color rojo los elementos (imágenes visuales o claves lingüísticas) que les llaman la atención y consideren importantes para comprender el texto. Después de unos minutos, se les pide que realicen una relectura y, dado que poseen el panorama completo del texto por su primera lectura, verifiquen si realmente los elementos seleccionados son necesarios, si ratifican sus decisiones dejarlos igual, si no lo son marcarlos con una equis y si quieren agregar nuevos deben encerrarlos en círculos azules.

Actividad desestructurante 5. A los sujetos se les solicita que lean el cuento gráfico Arthur Jermyn (Corben, 2016), mientras lo hacen deben con un lapicero marcar la trayectoria de su lectura.

Actividad desestructurante 6. Los sujetos leen el cuento gráfico ¿Qué era aquello? (Boix, 2009), mientras lo hacen deben observar y escribir glosas en las 
que indiquen qué les llama la atención, qué van entendiendo, qué consideran esencial para la comprensión y por qué.

\subsubsection{Módulo 2. Ejercicios cognitivos}

En la intervención los sujetos resuelven cincuenta ejercicios para el fortalecimiento de los procesos cognitivos básicos (Anexo 10). Se recopilan de diferentes fuentes (Fonseca, 1995; NGV, s.f.) o se crean teniendo en cuenta los objetivos de la investigación. Se organizan en ocho baterías descritas a continuación:

Batería 1. Búsqueda de diferencias. Se utilizan para fortalecer la atención selectiva y sostenida, además de la concentración. Los sujetos observan para identificar patrones y realizar búsqueda exhaustiva de información.

Batería 2. Secuencias. Se fortalece la realización de conexiones lógicas, predicciones a partir de la información disponible y el uso destrezas de razonamiento.

Batería 3. Razonamiento abstracto. Los sujetos resuelven problemas lógicos, deducen consecuencias de una situación planteada, analizan elementos por separado y en conjunto para identificar patrones.

Batería 4. Rompecabezas. Se fortalece la atención y la concentración a través de la aplicación de la capacidad de la observación, el análisis y el uso de la memoria visual para la predicción de un esquema final.

Batería 5. Selección de estímulos. Propician que los sujetos escojan, jerarquicen y mantengan activa información según las instrucciones de la tarea. Con ello, se logra generar, dirigir y mantener disponibles focos atencionales y se 
disminuya la recencia. La atención es una actividad cognitiva voluntaria o involuntaria, en la cual los sujetos se concentran o intensifican el grado de energía psíquica. La calidad de las respuestas depende de la variedad, la novedad y la repetición de la información en los textos, o la presencia de imágenes excitatorias.

Datería 6. Memoria. Permiten potenciar la capacidad de almacenar, guardar, codificar, retener y, posteriormente, recordar datos o información.

Datería 7. Percepción. Facilitan la identificación, la discriminación y la jerarquización de los estímulos externos visuales vinculándolos con el conocimiento previo.

Batería 8. Laberintos. Los ejercicios exigen el uso de ingenio y la atención sostenida, creación de estrategias para la resolución de problemas cuya información es de carácter espacial.

Con las baterías se busca que los sujetos de forma sistemática logren observar, preguntar, superponer, detallar, comparar, resaltar, abreviar, globalizar, deducir, sintetizar, reducir, organizar, prever, relacionar, descubrir elementos comunes, discriminar, asociar, abstraer, imaginar, estructurar, añadir, planear, relacionar establecer conceptos de espacio y tiempo, dirigir, seleccionar, categorizar, representar, agrupar, separar, resumir, calcular, escoger, reproducir, demostrar, descubrir, diseñar, extrapolar e interpolar (Carretero, 1995). Así mismo, se proyectan para fortalecer la habilidad visoespacial, lo que permite a los sujetos representar, analizar, manipular objetos mentalmente. Además, se identifica que, al incrementar el tiempo de exposición 
y su cantidad, los sujetos aumentan la velocidad y el ritmo de procesamiento. Mejoran con el entrenamiento.

\subsubsection{Módulo 3. Juegos de estrategia}

Con los diferentes juegos de estrategia, se busca fortalecer las funciones ejecutivas, definidas como un conjunto de capacidades cognitivas necesarias para controlar y autorregular la propia conducta. Es otras palabras, posibilitan establecer, mantener, supervisar, corregir y alcanzar un plan de acción dirigido a una tarea (Echevarría, 2017). Los sujetos al participar en los nueve juegos tienen que establecer objetivos, hacer planes de acción, tomar decisiones, generar estrategias, adaptarse a las situaciones, calcular tiempo y consecuencias, realizar tareas al mismo tiempo, ignorar los impulsos o la información irrelevante.

Los juegos seleccionados se encuentran en el mercado pero su uso se debe a que, al igual que los ejercicios cognitivos, ayudan a los sujetos a fortalecer sus procesos cognitivos de forma indirecta e inconsciente. Los sujetos disfrutan la participación en ellos, mientras lo hacen, cambian de una tarea a otra con mayor precisión y velocidad, mejoran la capacidad de razonar, resuelven problemas utilizando la información disponible y anticipándose según sea la meta propuesta. Igualmente toman decisiones bajo situaciones de incertidumbre a través de estrategias de razonamiento espacio-temporales y de planificación jerárquica. Los juegos se detallan en los siguientes apartes. 


\subsubsection{Juego 1. Tic, tac, boum.}

Participantes: 2 a 12 jugadores

Tiempo de juego: No determinado

Potencializa: Percepción, atención y memoria a largo plazo.

Indicaciones generales: Se deben escoger 13 tarjetas en las que están escritas sílabas de diferente complejidad y se ubican hacia abajo en el centro de la mesa; se sitúa la bomba al lado de las tarjetas, la cual es una alarma aleatoria que indica finalización del tiempo para cumplir con la tarea; se toma el dado que en sus caras tiene escrito tic (el sonido debe aparecer en una palabra al principio), tac (el sonido debe aparecer en una palabra al final) y boum (el sonido debe aparecer en una palabra en cualquier posición). Un jugador lanza el dado para saber la ubicación de la sílaba, toma la tarjeta al mismo tiempo que activan la bomba, cada jugador debe decir sus respuestas sin repetir palabras y luego pasa la bomba, pierde quien no pueda decir la respuesta rápidamente y se le active la bomba en las manos, debe quedarse con la tarjeta. El perdedor definitivo es aquel que después de 13 rondas tenga más tarjetas en su poder (Figura 13). Ese juego se vincula a los experimentos cronométricos de facilitación (priming), las tarjetas funcionan como prime y las respuestas de los sujetos como target. 
Figura 13

Juego 1. Tic, tac, boum (empresa Boing Games)

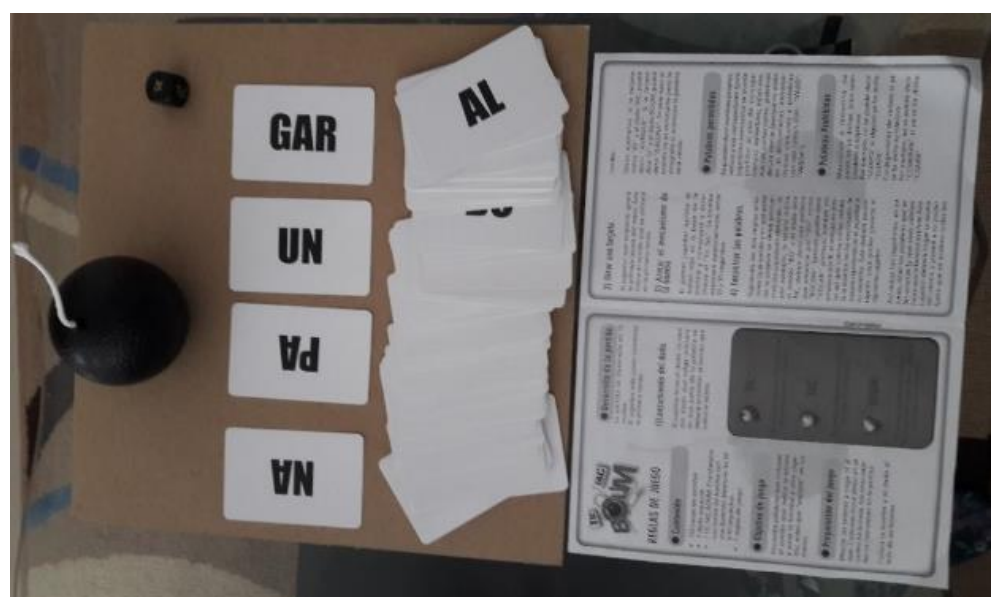

Fuente: Elaboración propia [fotografía]

\subsubsection{Juego 2. Adivina quién}

Participantes: 2 jugadores

Tiempo de juego: No determinado

Potencializa: Percepción, atención, concentración y memoria.

Indicaciones generales: Cada jugador organiza su tablero y selecciona su personaje de forma aleatoria o no. Deciden quién va a iniciar. Por cada turno se puede formular una pregunta y el contrincante únicamente puede responder si o no, si se acierta debe quitar los personajes que no cumplan con las características físicas por las que se indaga. Solo se puede adivinar el personaje del jugador contrario cuando se esté seguro, de lo contrario se pierde el partido. Gana el jugador que adivine primero (Figura 14). 


\section{Figura 14}

Adivina quién (empresa Hasbro Gaming)

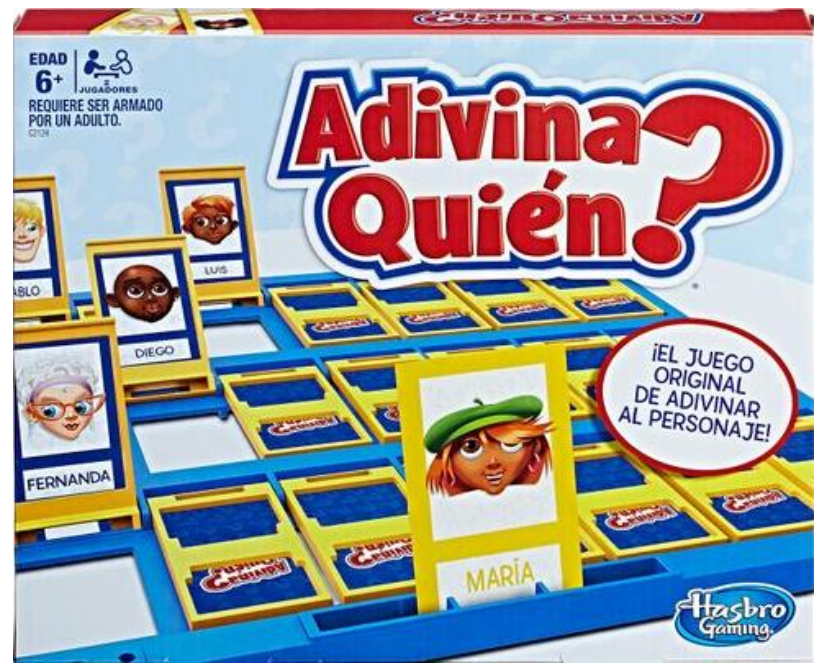

Fuente: Elaboración propia [fotografía]

\subsubsection{Juego 3. Puntos de colores}

Participantes: 2 jugadores.

Tiempo de juego: No determinado

Potencializa: Manejo de modelos bidimensionales, percepción visual, concentración, capacidad de planificación y organización para conseguir una meta, orientación en el espacio, propiedades de simetría y memoria.

Indicaciones generales: Se hacen 10 rondas. Cada jugador escoge una de las tarjetas de los niveles de forma ascendente, luego debe acomodar las 4 fichas en el tablero de manera que cada una ajuste dentro de cada cuadrado y que quede visible únicamente la cantidad de colores exacta que aparece en la ficha guía (Figura 15). 


\section{Figura 15}

Juego 3. Puntos de colores (empresa Entrenamiento Mental, juegos de madera)

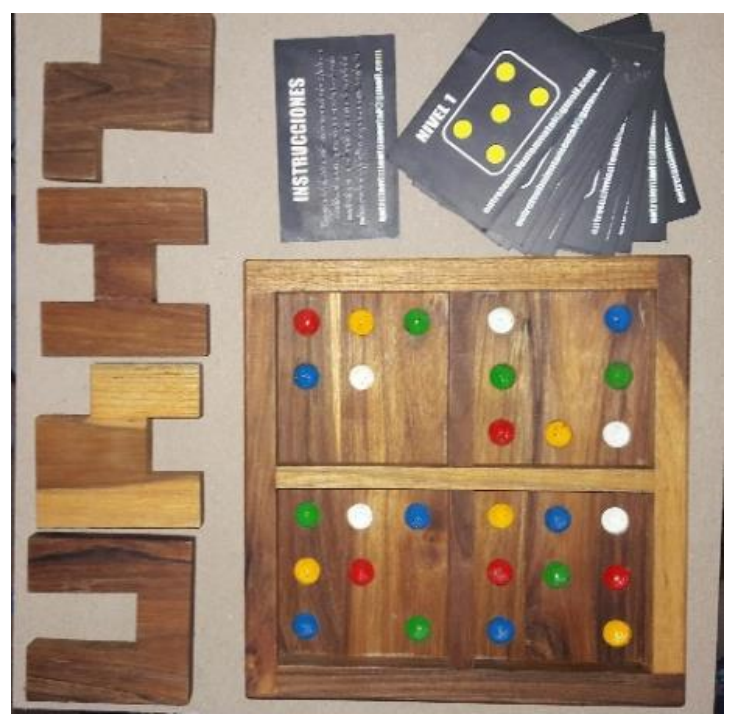

Fuente: Elaboración propia [fotografía]

\subsubsection{Juego 4. Parqueadero}

Participantes: 2 jugadores.

Tiempo de juego: No determinado

Potencializa: Manejo de modelos bidimensionales, percepción visual, concentración, capacidad de planificación y organización para conseguir una meta, orientación en el espacio, propiedades de traslación y simetría, memoria.

Indicaciones generales: Se hacen 10 rondas. El participante debe sacar el carro X por la entrada del parqueadero. Cada jugador escoge una de las tarjetas de los niveles de forma ascendente, cada carrito tiene en la parte superior una letra mayúscula diferente, hay que acomodarlos en la base de madera de acuerdo con la tarjeta seleccionada. El carro X se encuentra obstaculizado por otros carros, se debe 
sacar del parqueadero, por ello, hay que realizar desplazamientos horizontales y verticales sin levantar ningún vehículo (Figura 16).

Figura 16

Juego 4. Parqueadero (empresa Entrenamiento Mental, juegos de madera)

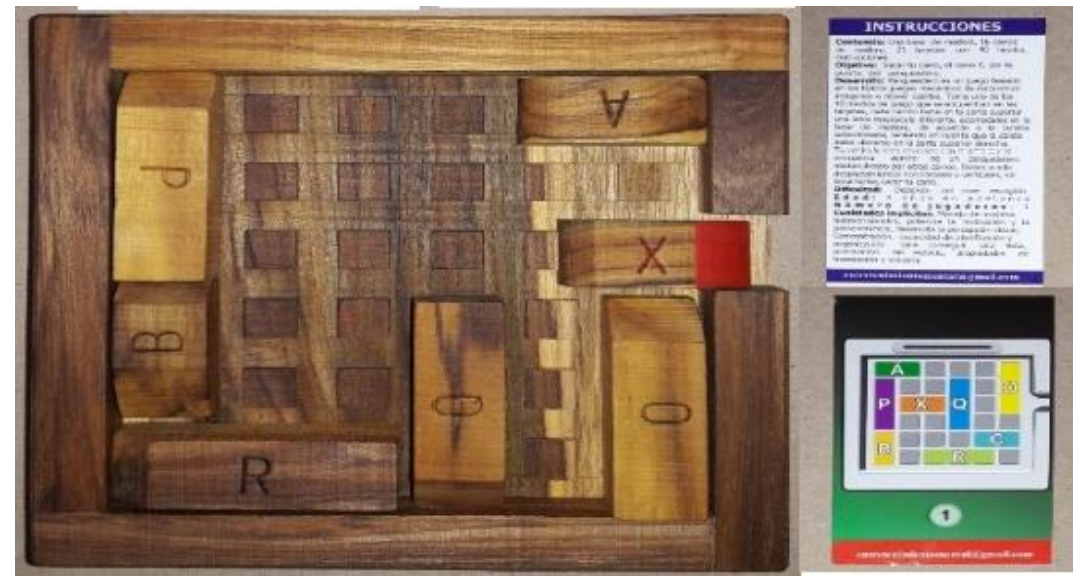

Fuente: Elaboración propia [fotografía]

\subsubsection{Juego 5. Circuito}

Participantes: 2 jugadores.

Tiempo de juego: No determinado

Potencializa: Percepción visual, concentración, capacidad de planificación y organización para conseguir una meta, orientación en el espacio, propiedades de traslación y simetría, memoria.

Indicaciones generales: Se hacen 10 rondas. Cada jugador escoge una de las tarjetas de los niveles de forma ascendente, luego debe acomodar las fichas indicadas según el reto para unirlas y formar un circuito exactamente como aparece en la ficha guía. Las líneas azules deben encajar con las líneas azules, las líneas amarillas con las 
líneas amarillas y las formas deben progresar tal cual como se solicita utilizando el número de piezas que indica la tarjeta (Figura 17).

\section{Figura 17}

Juego 5. Circuito (empresa Entrenamiento Mental, juegos de madera)

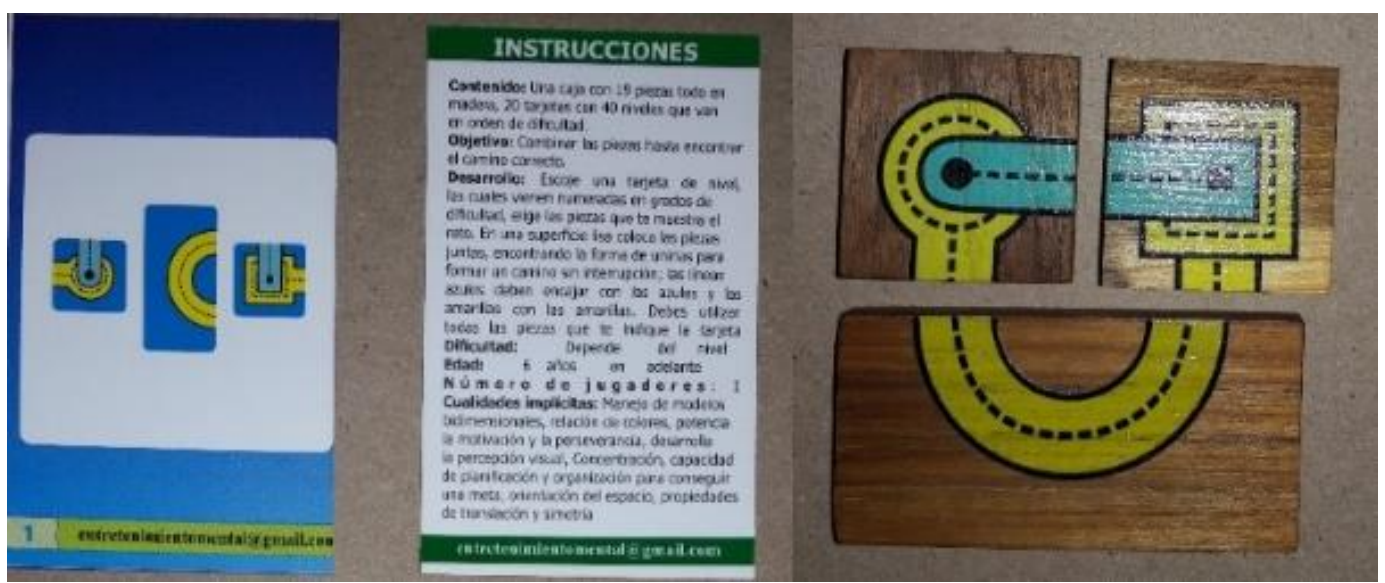

Fuente: Elaboración propia [fotografía]

\subsubsection{Juego 6. Lectura de imágenes}

Participantes: 2 jugadores.

Tiempo de juego: No determinado

Potencializa: Percepción visual, atención, concentración y memoria.

Indicaciones generales: En el centro de la mesa se coloca el mazo de las tarjetas hacia abajo. Uno de los jugadores voltea la tarjeta de encima y cada uno debe descubrir la diferencia entre las imágenes de su zona, al encontrarla debe decirla en voz alta, gana el que lo haga más rápido. Si el jugador acierta recolecta la tarjeta, de lo contrario el otro jugador tiene la oportunidad de compartir la diferencia que identifica. Si nadie acierta la tarjeta pasa al final del mazo, gana el juego quien obtenga el mayor número de tarjetas (Figura 18). 
Figura 18

Juego 6. Lectura de imágenes (empresa Lee Colombia)

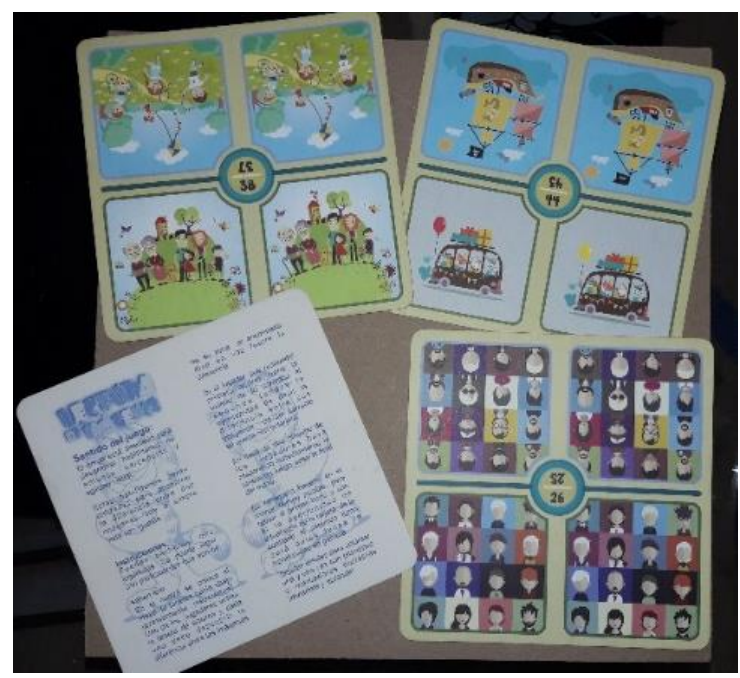

Fuente: Elaboración propia [fotografía]

\subsubsection{Juego 7. Razonamiento abstracto}

Participantes: 2 jugadores, un administrador de tarjetas y respuestas.

Tiempo de juego: No determinado

Potencializa: Razonamiento lógico abstracto, análisis, razonar utilizando

símbolos y basándose en conceptos para resolver situaciones nuevas, resolución de problemas, percepción visual, atención, concentración.

Indicaciones generales: En el centro de la mesa se coloca el mazo de las tarjetas hacia abajo. Uno de los jugadores voltea la tarjeta de encima y cada uno debe resolver el problema propuesto que aparece en su zona, luego ubicar la ficha de parqués en la opción correspondiente. Después que los dos jugadores hayan respondido se debe verificar si acertaron, si los dos dieron la respuesta correcta gana 
quien responde primero y si nadie responde bien la tarjeta pasa al final del mazo, gana el juego quien obtenga el mayor número de tarjetas (Figura 19).

\section{Figura 19}

Juego 7. Razonamiento abstracto (empresa Lee Colombia)

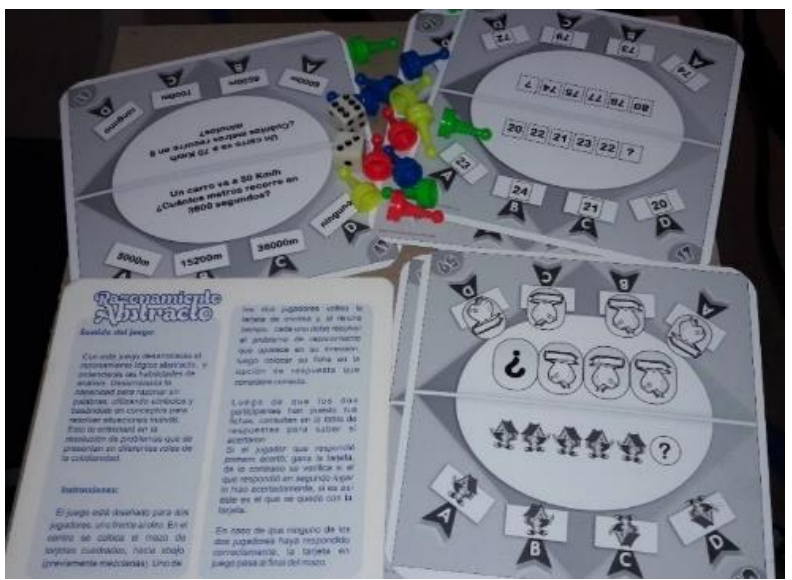

Fuente: Elaboración propia [fotografía]

\subsubsection{Juego 8. Pingüinos memoriosos}

Participantes: 2 jugadores.

Tiempo de juego: No determinado

Potencializa: Percepción, atención, concentración y memoria.

Indicaciones generales: OPCIÓN 1. Dentro de los 42 pingüinos se encuentran bolitas de color amarillo, rosa, azul, rojo, negro y verde. Cada jugador en su turno podrá levantar dos pingüinos, si coinciden los colores se le permite sacar las bolitas y conservarla, gana quien al final posea el mayor número de bolitas. OPCIÓN 2: Dentro de los 42 pingüinos se encuentran las bolitas. El jugador en su turno lanza un dado, que en cada cara tiene uno de los colores mencionados, después debe levantar dos pingüinos, si coincide el color del dado con las bolitas puede conservarlas si no tendrá 
que esperar los turnos necesarios hasta encontrar las bolitas del color solicitado, gana quien al final posea el mayor número de bolitas (Figura 20).

\section{Figura 20}

Juego 8. Pingüinos memoriosos (empresa Entrenamiento Mental, juegos de madera)

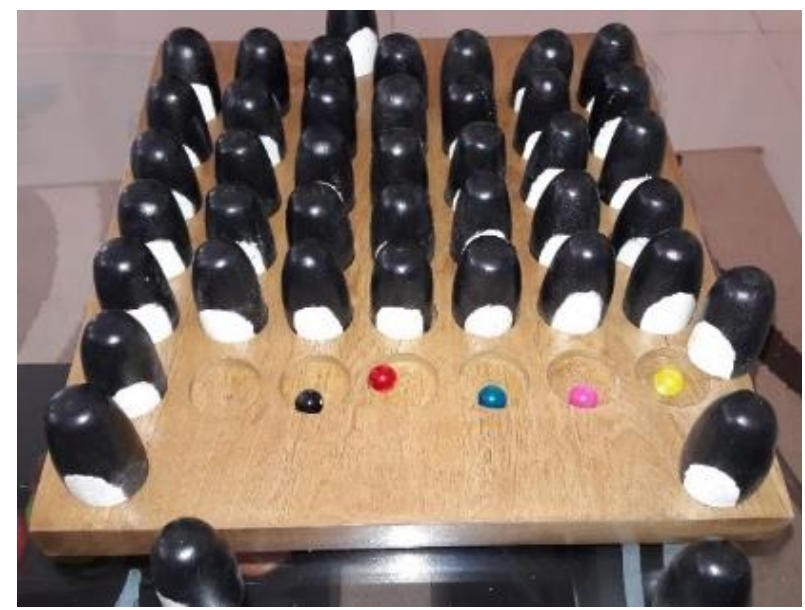

Fuente: Elaboración propia [fotografía]

\subsubsection{Juego 9. Barricada}

Participantes: 2 o 4 jugadores

Tiempo de juego: No determinado

Potencializa: Percepción visual, concentración, capacidad de planificación y organización para conseguir una meta, resolución de problemas, toma de decisiones, análisis, orientación en el espacio, memoria.

Indicaciones generales: Se utiliza un dado y 4 grupos de 5 piezas de un mismo color. Cada uno de estos grupos comienza la partida situados en su respectiva ubicación, en la zona inferior del tablero. Cuando participan 2 jugadores cada uno de ellos lo hace con 2 colores alternos (por ejemplo rojo y amarillo frente a verde y azul). Si son 4 jugadores, cada uno utiliza un color, escogiendo jugar de manera individual o 
por parejas. Además de las 20 piezas de colores existen otras 11 piezas blancas, a las que se denomina barricadas y que no pertenecen a ningún jugador, al inicio de la partida se ubican en unas posiciones determinadas del tablero, pero los jugadores pueden ganarlas y luego usarlas para obstaculizar el avance de sus contrincantes. El objetivo del juego es alcanzar antes que los rivales la posición superior del tablero con al menos una de las piezas (Figura 21).

\section{Figura 21}

Juego 9. Barricada (empresa Entrenamiento Mental, juegos de madera)

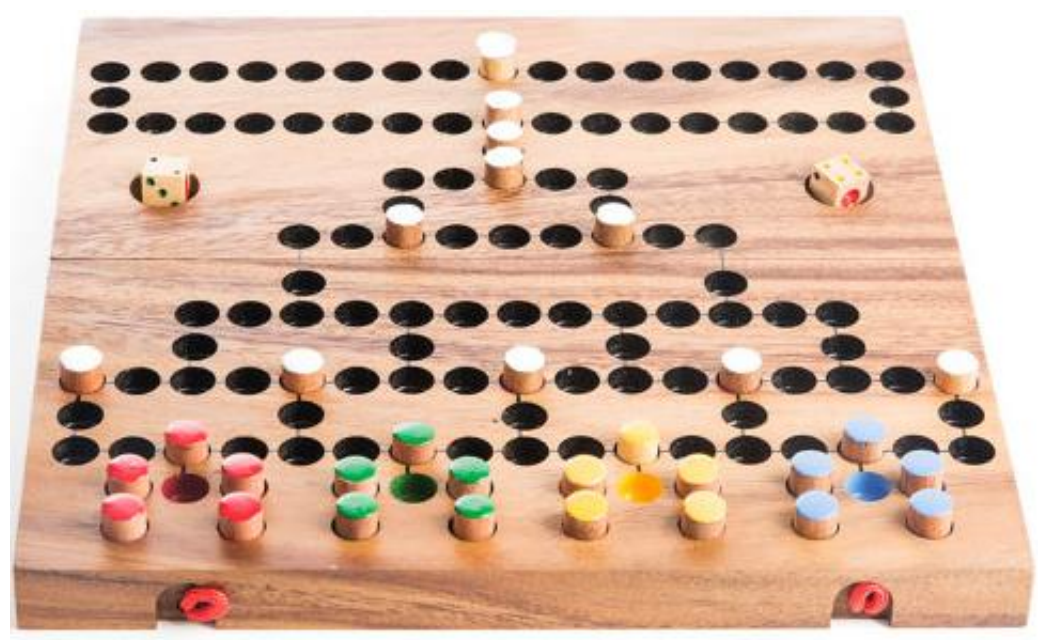

Fuente: Elaboración propia [fotografía]

Los ejercicios cognitivos y los juegos de estrategia buscan fortalecer en los sujetos el empleo de informaciones diferentes y ver las posibles conexiones entre ellas. Es decir, razonar de forma hipotética, escudriñar las condiciones e imaginar posibilidades de solución, cambiando elementos y anticipándose a resultados. Razonar transitivamente, inferir a partir de lo explícito, codificar, representar, revertir. Razonar 
analógicamente, establecer vínculos, comparar, transponer. Razonar desde lo lógico, basarse en evidencias, detallar de lo particular a lo general y viceversa. Razonar desde lo abstracto, resolver retos de imágenes y conceptos visuales, proyectar (Cedillo, 2010). Se propicia el uso de operaciones mentales como observar, preguntar, superponer, detallar, comparar, resaltar, abreviar, globalizar, deducir, sintetizar, reducir, organizar, prever, relacionar, descubrir elementos comunes, discriminar, asociar, abstraer, imaginar, estructurar, añadir, planear, relacionar establecer conceptos de espacio y tiempo, dirigir, seleccionar, categorizar, representar, agrupar, separar, resumir, calcular, escoger, reproducir, demostrar, descubrir, diseñar, extrapolar, interpolar.

En la intervención se exponen a los sujetos a situaciones desafiantes para incrementar el banco de experiencias visuales. Los ejercicios cognitivos y los juegos se seleccionan especialmente para alentarlos a profundizar y fortalecer la habilidad de procesar lo visual, exponerlos a retos cognitivos que los obliguen a afinar procesos y operaciones cognitivas, lo que favorece indirectamente la comprensión de textos verbovisuales narrativos.

\subsubsection{Módulo 4. Fundamentación sobre la imagen visual}

Los sujetos desde su nacimiento están expuestos a claves lingüísticas e imágenes visuales. En los años de escolarización se les enseña principalmente a codificar y decodificar letras. No obstante, los códigos visuales se asumen como transparentes porque se vive en un mundo plagado de imágenes, lo que ocasiona que se crea que se conocen de antemano y no suponen ningún esfuerzo para su 
interpretación. Se puede pensar que la lectura de las imágenes facilita ignorar los elementos irrelevantes dentro de un texto, los mensajes son explícitos, se disminuye la imaginación y cuando se construyen conceptualizaciones las ilustraciones estorban (Arizpe y Styles, 2004). Nada más alejado de la verdad porque se desconocen las relaciones de simetría, ampliación, complementariedad que tienen las imágenes visuales, además, de su valor connotativo.

La imagen visual debe ser analizada como arte, realismo, medio, estilo, forma, expresividad de emociones y de puntos de vista. Pensar en imágenes es una operación técnicamente distinta que pensar en palabras porque el significado de una pintura o una sinfonía no pueden traducirse a palabras, son de existencia diferente. Una experiencia visual demanda una respuesta visual a su forma original. Los textos gráficos son herramientas para entender el desarrollo cognitivo y cualidades estéticas (Gómez, 2015; Zavala, s.f.; Rojas, 2013; Linero, s.f.). Por ello, se propone reflexionar entre los sujetos y el investigador sobre aspectos conceptuales básicos de la imagen visual para brindar herramientas técnicas que permitan incrementar el grado de pericia y los marcos de conocimiento que desencadenan en una lectura de textos verbovisuales más meticulosa y, en consecuencia, en el mejoramiento de su comprensión.

Se trabajan los componentes de la imagen desde el análisis objetivo, denotativo o formal. Se abordan los elementos escalares como el tamaño y el espacio; en los elementos morfológicos se estudia el punto, la línea, el color, la luz, el contraste, la textura y la forma; en los elementos dinámicos se examina la composición, el ritmo, el encuadre, la angulación, los planos y la profundidad. En cuanto al análisis connotativo 
o subjetivos (creencias, conocimientos y estados anímicos), se realizan ejercicios para identificar la intención del autor, la relación texto- lector, los objetivos de la imagen, los estereotipos, los prejuicios y la discriminación. Finalmente, en el análisis conceptual se reflexiona sobre la función o acción de los elementos de una imagen, los tipos de anclaje de la imagen en el contexto y el nivel de representación y modos de expresión en la imagen visual.

Igualmente, se estudian las relaciones cuantitativas referidas a la cantidad de palabras o texto frente a la imagen o la cantidad de imágenes frente a la cantidad de texto, para ello, se detallan las funciones de la imagen (descriptiva, informativa, estética, expresiva, comunicativa), la vinculación imagen-palabra (ornamental, subsidiaria, complementaria o significativa) y los tipos de relación imagen-palabra (anclaje o apoyo, parasitismo, simbiosis, extrañeza); se estudian las relaciones cualitativas direccionas al establecimiento de las figuras retóricas y las relaciones semánticas como monosemia / polisemia, iconicidad / abstracción, denotación / connotación.

\subsection{PLANEACIÓN DE SESIONES}

Se desarrollan 14 sesiones cada una de tres horas. En la sesión 1 se realizan las actividades técnicas y logísticas necesarias para el inicio de la ejecución del estudio. Las sesiones 2 al 14 son propiamente el desarrollo del protocolo de intervención de la investigación. El detalle de cada sesión se presenta a continuación en la tabla 4. 


\section{Tabla 4}

Planeación de sesiones del protocolo de intervención

\begin{tabular}{|c|c|c|c|}
\hline SESIÓN & ACTIVIDAD & OBJETIVO & RECURSO \\
\hline 1 & $\begin{array}{ll}\text { 1. } & \text { Explicación ejecutiva } \\
\text { de la investigación. } \\
\text { 2. Diligenciamiento del } \\
\text { consentimiento } \\
\text { informado. } \\
\text { 3. Diligenciamiento de } \\
\text { encuesta diagnóstica. } \\
\text { Realización de sesión } \\
\text { grupal. }\end{array}$ & $\begin{array}{l}\text { Socializar de forma sintética la } \\
\text { investigación para que los } \\
\text { sujetos conozcan en que están } \\
\text { participando. } \\
>\text { Seleccionar la muestra y definir } \\
\text { grupo de estudio y grupo } \\
\text { control. } \\
\text { Explorar el conocimiento previo } \\
\text { y el grado de exposición a los } \\
\text { textos narrativos verbovisuales } \\
\text { por parte de la muestra. }\end{array}$ & $\begin{array}{l}>\text { Prueba } \\
\text { diagnóstica } \\
>\quad \begin{array}{l}\text { Consentimien } \\
\text { to informado }\end{array} \\
>\quad \text { Encuesta de } \\
\text { survey } \\
\text { monkey }\end{array}$ \\
\hline 2 & 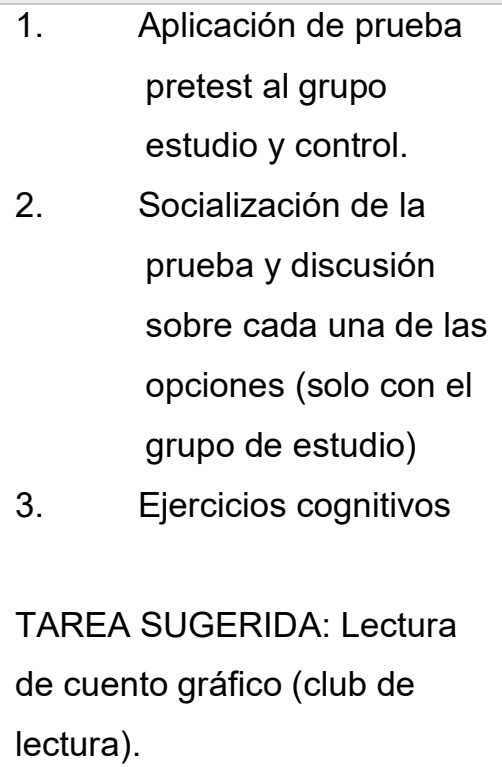 & $\begin{array}{l}\text { Aplicar la prueba pretest para } \\
\text { recoger información preliminar } \\
\text { sobre el nivel de comprensión. } \\
\text { Exponer a los sujetos a retos } \\
\text { cognitivos que los obliguen a } \\
\text { incrementar el uso de procesos } \\
\text { y operaciones cognitivas, las } \\
\text { cuales favorezcan } \\
\text { indirectamente la comprensión } \\
\text { de textos verbovisuales. }\end{array}$ & $\begin{array}{l}>\text { Diario de } \\
\text { campo } \\
>\text { Cuentos } \\
\text { gráficos } \\
\text { verbovisuales } \\
. \\
>\text { Cuaderno de } \\
\text { ejercicios. }\end{array}$ \\
\hline 3 y 4 & $\begin{array}{l}\text { 1. Club de lectura. } \\
\text { 2. Ejercicios cognitivos } \\
\text { 3. Diálogo sobre aspectos } \\
\text { constitutivos de las claves } \\
\text { lingüísticas y la imagen } \\
\text { visual, necesarios para la } \\
\text { comprensión textual. } \\
\text { 4. Actividades } \\
\text { desestructurantes. }\end{array}$ & $\begin{array}{l}\text { Exponer a los sujetos a retos } \\
\text { cognitivos que los obliguen a } \\
\text { incrementar el uso de procesos } \\
\text { y operaciones cognitivas, las } \\
\text { cuales favorezcan } \\
\text { indirectamente la comprensión } \\
\text { de textos verbovisuales. } \\
\text { Proporcionar a los sujetos } \\
\text { información teórica sobre las }\end{array}$ & $\begin{array}{l}\text { - Diario de } \\
\text { campo } \\
\text { - Cuentos } \\
\text { gráficos } \\
\text { verbovisuales } \\
\text { - } \\
\text { Cuaderno de } \\
\text { ejercicios } \\
\text { cognitivos. }\end{array}$ \\
\hline
\end{tabular}




\begin{tabular}{|c|c|c|c|}
\hline & $\begin{array}{l}\text { 5. Juego de estrategia. } \\
\text { 6. Recapitulación de } \\
\text { aprendizajes de la sesión. } \\
\text { TAREA SUGERIDA: Lectura } \\
\text { de cuento gráfico (club de } \\
\text { lectura). }\end{array}$ & $\begin{array}{l}\text { claves lingüísticas y la imagen } \\
\text { visual. } \\
\text { Recoger información para } \\
\text { comprender cómo hacen los } \\
\text { sujetos para procesar textos } \\
\text { verbovisuales. }\end{array}$ & $\begin{array}{l}\text { - Juegos de } \\
\text { estrategia. }\end{array}$ \\
\hline 5 & $\begin{array}{l}\text { 1. Aplicación de prueba } \\
\text { monitoreo } 1 \text { al grupo } \\
\text { estudio. } \\
\text { 2. Socialización de la prueba } \\
\text { y discusión sobre cada } \\
\text { una de las opciones. } \\
\text { 3. Ejercicios cognitivos. } \\
\text { 4. Diálogo sobre aspectos } \\
\text { constitutivos de las claves } \\
\text { lingüísticas y la imagen } \\
\text { visual, necesarios para la } \\
\text { comprensión textual. } \\
\text { TAREA SUGERIDA: Lectura } \\
\text { de cuento gráfico (club de } \\
\text { lectura). }\end{array}$ & $\begin{array}{l}\text { Realizar el seguimiento al } \\
\text { proceso de los sujetos } \\
\text { comparando los resultados de } \\
\text { las pruebas de comprensión. } \\
\text { - Exponer a los sujetos a retos } \\
\text { cognitivos que lo obliguen a } \\
\text { incrementar el uso de procesos } \\
\text { y operaciones cognitivas, las } \\
\text { cuales favorezcan } \\
\text { indirectamente la comprensión } \\
\text { de textos verbovisuales. } \\
\text { Proporcionar a los sujetos } \\
\text { información teórica sobre las } \\
\text { claves lingüísticas y la imagen } \\
\text { visual. } \\
\text { Recoger información para } \\
\text { comprender cómo hacen los } \\
\text { sujetos para procesar textos } \\
\text { verbovisuales. }\end{array}$ & $\begin{array}{ll}\text { - } & \text { Diario de } \\
\text { campo } \\
\text { - } & \text { Cuentos } \\
\text { gráficos } \\
\text { verbovisuales } \\
\text { - Cuaderno de } \\
\text { ejercicios } \\
\text { cognitivos. }\end{array}$ \\
\hline 6 y 7 & $\begin{array}{l}\text { 1. Club de lectura. } \\
\text { 2. Ejercicios cognitivos. } \\
\text { 3. Diálogo sobre aspectos } \\
\text { constitutivos de las claves } \\
\text { lingüísticas y la imagen } \\
\text { visual, necesarios para la } \\
\text { comprensión textual. } \\
\text { 4. Actividades } \\
\text { desestructurantes. } \\
\text { 5. Juego de estrategia. } \\
\text { 6. Recapitulación de }\end{array}$ & $\begin{array}{l}\text { Exponer a los sujetos a retos } \\
\text { cognitivos que los obliguen a } \\
\text { incrementar el uso de procesos } \\
\text { y operaciones cognitivas, las } \\
\text { cuales favorezcan } \\
\text { indirectamente la comprensión } \\
\text { de textos verbovisuales. } \\
\text { Proporcionar a los sujetos } \\
\text { información teórica sobre las } \\
\text { claves lingüísticas y la imagen } \\
\text { visual. }\end{array}$ & $\begin{array}{l}\text { - Diario de } \\
\text { campo } \\
\text { - Cuentos } \\
\text { gráficos } \\
\text { verbovisuales } \\
\text { - } \\
\text { Cuaderno de } \\
\text { ejercicios } \\
\text { cognitivos. } \\
\text { Juegos de } \\
\text { estrategia. }\end{array}$ \\
\hline
\end{tabular}




\begin{tabular}{|c|c|c|c|}
\hline & $\begin{array}{l}\text { aprendizajes de la sesión. } \\
\text { TAREA SUGERIDA: Lectura } \\
\text { de cuento gráfico (club de } \\
\text { lectura). }\end{array}$ & $\begin{array}{l}\text { Recoger información para } \\
\text { comprender cómo hacen los } \\
\text { sujetos para procesar textos } \\
\text { verbovisuales. }\end{array}$ & \\
\hline 8 & $\begin{array}{l}\text { 1. Aplicación de prueba } \\
\text { monitoreo } 2 \text { al grupo } \\
\text { estudio. } \\
\text { 2. Socialización de la prueba } \\
\text { y discusión sobre cada } \\
\text { una de las opciones. } \\
\text { 3. Ejercicios cognitivos. } \\
\text { 4. Diálogo sobre aspectos } \\
\text { constitutivos de las claves } \\
\text { lingüísticas y la imagen } \\
\text { visual, necesarios para la } \\
\text { comprensión textual. } \\
\text { TAREA SUGERIDA: Lectura } \\
\text { de cuento gráfico (club de } \\
\text { lectura). }\end{array}$ & $\begin{array}{l}\text { Realizar el seguimiento al } \\
\text { proceso de los sujetos } \\
\text { comparando los resultados de } \\
\text { las pruebas de comprensión. } \\
\text { - Exponer a los sujetos a retos } \\
\text { cognitivos que lo obliguen a } \\
\text { incrementar el uso de procesos } \\
\text { y operaciones cognitivas, las } \\
\text { cuales favorezcan } \\
\text { indirectamente la comprensión } \\
\text { de textos verbovisuales. } \\
\text { Proporcionar a los sujetos } \\
\text { información teórica sobre las } \\
\text { claves lingüísticas y la imagen } \\
\text { visual. } \\
\text { Recoger información para } \\
\text { comprender cómo hacen los } \\
\text { sujetos para procesar textos } \\
\text { verbovisuales. }\end{array}$ & $\begin{array}{ll}\text { - } & \text { Diario de } \\
\text { campo } \\
\text { - } & \text { Cuentos } \\
\text { gráficos } \\
\text { verbovisuales } \\
\text { - Cuaderno de } \\
\text { ejercicios } \\
\text { cognitivos. }\end{array}$ \\
\hline 9 y 10 & $\begin{array}{l}\text { 1. Club de lectura. } \\
\text { 2. Ejercicios cognitivos } \\
\text { 3. Diálogo sobre aspectos } \\
\text { constitutivos de las claves } \\
\text { lingüísticas y la imagen } \\
\text { visual, necesarios para la } \\
\text { comprensión textual. } \\
\text { 4. Actividades } \\
\text { desestructurantes. } \\
\text { 5. Juego de estrategia. } \\
\text { 6. Recapitulación de } \\
\text { aprendizajes de la sesión. }\end{array}$ & $\begin{array}{l}\text { Exponer a los sujetos a retos } \\
\text { cognitivos que los obliguen a } \\
\text { incrementar el uso de procesos } \\
\text { y operaciones cognitivas, las } \\
\text { cuales favorezcan } \\
\text { indirectamente la comprensión } \\
\text { de textos verbovisuales. } \\
\text { Proporcionar a los sujetos } \\
\text { información teórica sobre las } \\
\text { claves lingüísticas y la imagen } \\
\text { visual. } \\
\text { Recoger información para } \\
\text { comprender cómo hacen los }\end{array}$ & 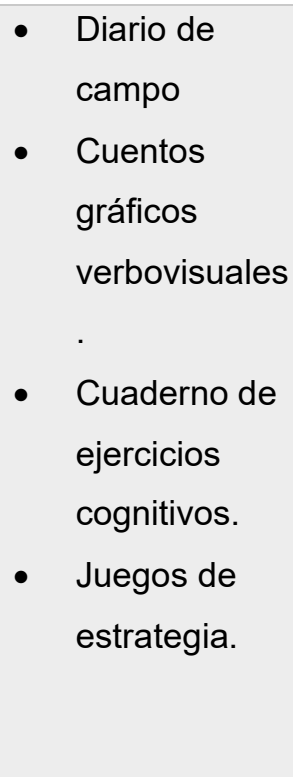 \\
\hline
\end{tabular}




\begin{tabular}{|c|c|c|c|}
\hline & $\begin{array}{l}\text { TAREA SUGERIDA: Lectura } \\
\text { de cuento gráfico (club de } \\
\text { lectura). }\end{array}$ & $\begin{array}{l}\text { sujetos para procesar textos } \\
\text { verbovisuales. }\end{array}$ & \\
\hline 11 & $\begin{array}{l}\text { 1. Aplicación de prueba } \\
\text { monitoreo } 3 \text { al grupo } \\
\text { estudio. } \\
\text { 2. Socialización de la prueba } \\
\text { y discusión sobre cada } \\
\text { una de las opciones. } \\
\text { 3. Ejercicios cognitivos. } \\
\text { 4. Diálogo sobre aspectos } \\
\text { constitutivos de las claves } \\
\text { lingüísticas y la imagen } \\
\text { visual, necesarios para la } \\
\text { comprensión textual. } \\
\text { TAREA SUGERIDA: Lectura } \\
\text { de cuento gráfico (club de } \\
\text { lectura). }\end{array}$ & $\begin{array}{l}\text { Realizar el seguimiento al } \\
\text { proceso de los sujetos } \\
\text { comparando los resultados de } \\
\text { las pruebas de comprensión. } \\
\text { - Exponer a los sujetos a retos } \\
\text { cognitivos que lo obliguen a } \\
\text { incrementar el uso de procesos } \\
\text { y operaciones cognitivas, las } \\
\text { cuales favorezcan } \\
\text { indirectamente la comprensión } \\
\text { de textos verbovisuales. } \\
\text { Proporcionar a los sujetos } \\
\text { información teórica sobre las } \\
\text { claves lingüísticas y la imagen } \\
\text { visual. } \\
\text { Recoger información para } \\
\text { comprender cómo hacen los } \\
\text { sujetos para procesar textos } \\
\text { verbovisuales. }\end{array}$ & $\begin{array}{ll}\text { - } & \text { Diario de } \\
\text { campo } \\
\text { - } & \text { Cuentos } \\
\text { gráficos } \\
\text { verbovisuales } \\
\text { - Cuaderno de } \\
\text { ejercicios } \\
\text { cognitivos. }\end{array}$ \\
\hline 12 y 13 & $\begin{array}{l}\text { 1. Club de lectura. } \\
\text { 2. Ejercicios cognitivos. } \\
\text { 3. Diálogo sobre aspectos } \\
\text { constitutivos de las claves } \\
\text { lingüísticas y la imagen } \\
\text { visual, necesarios para la } \\
\text { comprensión textual. } \\
\text { 4. Actividades } \\
\text { desestructurantes. } \\
\text { 5. Juego de estrategia. } \\
\text { 6. Recapitulación de } \\
\text { aprendizajes de la sesión. } \\
\text { TAREA SUGERIDA: Lectura } \\
\text { de cuento gráfico (club de }\end{array}$ & $\begin{array}{l}\text { Exponer a los sujetos a retos } \\
\text { cognitivos que los obliguen a } \\
\text { incrementar el uso de procesos } \\
\text { y operaciones cognitivas, las } \\
\text { cuales favorezcan } \\
\text { indirectamente la comprensión } \\
\text { de textos verbovisuales. } \\
\text { - Proporcionar a los sujetos } \\
\text { información teórica sobre las } \\
\text { claves lingüísticas y la imagen } \\
\text { visual. } \\
\text { Recoger información para } \\
\text { comprender cómo hacen los } \\
\text { sujetos para procesar textos } \\
\text { verbovisuales. }\end{array}$ & $\begin{array}{l}\text { Diario de } \\
\text { campo } \\
\text { - Cuentos } \\
\text { gráficos } \\
\text { verbovisuales } \\
\text { - Cuaderno de } \\
\text { ejercicios } \\
\text { cognitivos. } \\
\text { Juegos de } \\
\text { estrategia. }\end{array}$ \\
\hline
\end{tabular}




\begin{tabular}{|l|l|l|l|}
\hline \multicolumn{2}{|l|}{ lectura). } & & \\
\hline 14 & $\begin{array}{l}\text { Prueba post test grupo estudio } \\
\text { y grupo control. }\end{array}$ & $\begin{array}{l}\text { Aplicación de la prueba final al } \\
\text { grupo estudio y grupo control. }\end{array}$ & $\bullet$ Prueba final \\
\hline
\end{tabular}

Fuente: Elaboración propia

En las sesiones se emplean cada uno de los cuatro módulos señalados, pero el tiempo dedicado a cada uno de ellos depende de los avances de los sujetos y las condiciones socioambientales. Las actividades de intervención se enfocan en dialogar sobre los conocimientos y la realización de tareas asociadas a la comprensión de textos verbovisuales narrativos.

\subsection{RECAPITULACIÓN}

El protocolo de intervención es la planeación del estudio de caso en relación con los tiempos, los recursos y los propósitos de la investigación. Se remarca desde la teoría de la modificabilidad cognitiva al reconocer que se pueden causar cambios estructurales provocados en los organismos gracias a programas deliberados de intervención para facilitar un crecimiento continuo de las capacidades perceptivas, cambios que afectan a los sujetos, quienes se exponen a estímulos internos y externos que promueven cambios en las estructuras mentales gracias al ambiente y la mediación.

La intervención se asume como una experiencia de aprendizaje mediado en el que se operacionalizan las variables. La variable independiente se manipula para lograr que los sujetos, mientras leen, se vean obligados a reconocer y analizar tanto los aspectos denotativos, connotativos y conceptuales de la imagen visual, como los aspectos microestructurales, superestructurales, macroestructurales en los textos 
partiendo de las claves lingüísticas. Lo expresado está pensado para afectar la variable dependiente, es decir, se crean las condiciones para la modificabilidad en la comprensión lo que implica el incremento de la experticia en la recuperación de la información (muestro), la producción de inferencias (predicción, anticipación, confirmación y autocorrección), la reflexión y la evaluación de la información. Además, se reconoce la influencia de la variable interviniente asociada con el conocimiento previo y el grado de exposición a textos verbovisuales narrativos que posibilita la selección u omisión de información textual y enciclopédica.

En este orden de ideas, se emplean textos verbovisuales narrativos, específicamente el cuento gráfico, para rastrear el comportamiento de los sujetos al procesar la imagen visual frente las claves lingüísticas, paralelamente se incrementa el grado de exposición y pericia en su abordaje. Los ejercicios cognitivos y los juegos de estrategias tienen como fin el fortalecimiento de los procesos cognitivos que apalancan la comprensión. La fundamentación teórica sobre la imagen visual actualiza los marcos de conocimiento que facilitan la vinculación entre los datos y la complejidad en la reconstrucción del sentido. Desde esta perspectiva la comprensión no se limita a la actividad pasiva de transferencia donde el sujeto lee e interpreta un texto; implica movilizar las estructuras mentales para dotar al sujeto de mecanismos que posibiliten la transformación de los estímulos textuales y su escudriñamiento a profundidad. 


\section{PARTE II}




\section{CAPÍTULO 4}

\section{HALLAZGOS DESDE LO}

CUANTITATIVO 


\subsection{INTRODUCCIÓN}

Los capítulos 4 y 5 de la parte II son complementarios. El capítulo 4 presenta el análisis cuantitativo encaminado a la validación o no de la hipótesis de investigación. El capítulo 5 muestra el análisis cualitativo de los datos recopilados en el proceso de intervención y vistos a la luz de los aspectos abordados en los capítulos 1, 2 y 3 . En este orden de ideas, en el presente capítulo se comparten los resultados obtenidos al comparar los desempeños del grupo de estudio con el grupo control al resolver pruebas de comprensión sobre textos verbovisuales narrativos, y el análisis intragrupal del grupo de estudio a partir de las pruebas de monitoreo. Para ello, se realiza el planteamiento y el contraste de la hipótesis, se indican los intervalos de confianza para la diferencia de proporciones entre grupos, se muestran las curvas de aprendizaje de los sujetos y de los grupos, finalmente, para constatar la efectividad o no del tratamiento se realiza el análisis multivariado y la prueba de Clúster.

\subsection{ANÁLISIS CUANTITATIVO}

De Vega y Cuetos (1991) afirman que: "En el lenguaje escrito los estímulos están disponibles todo el tiempo y el lector puede procesarlos cuantas veces quiera y al ritmo que desee. Lo que permite repaso o vuelta atrás; aceleración considerable de la comprensión en algunos casos" (p. 24). En otras palabras, la comprensión está certificada si los sujetos tienen acceso directo al texto de lectura. Bruning et al. (2005) aseveran que:

[...] las personas registran una gran cantidad de información que se les muestra en breves exposiciones, cuando esta información se les quita de su vista, 
solamente queda a su disposición durante un escaso periodo de tiempo (0.5 segundos) dado que la memoria visual es limitada, procesa poco de lo que recibe de 7 a 9 piezas" (p. 27).

En los experimentos en contextos naturales y ligados a procesos de comprensión evidenciados por la producción, el input es externo y el output es interno (De Vega y Cuetos, 1991). Lo anterior, acarrea sesgo en la medición de las respuestas, puesto que el sujeto no dice siempre la verdad, pueda que no comprenda, olvide con facilidad o agregue información para impresionar al experimentador (Lohr, 2000). Para contrarrestar el sesgo de medición se acude a la repetición de la prueba o pruebas piloto. De esta forma se logra un anticipo de los resultados, que sirve de escala de comparación para evaluar la normalidad y la validez externa de la prueba definitiva; y los cambios observados pueden atribuirse a la manipulación experimental y la comparación de los grupos, es decir, validez interna. La administración de medidas repetitivas permite evaluar la variable dependiente según el efecto de la variable independiente y la influencia indirecta de la variable interviniente.

\subsubsection{Hipótesis y subhipótesis}

Los resultados de las pruebas de comprensión pretest, post test y monitoreos se someten a análisis estadístico con el fin de proporcionar evidencias suficientes para confirmar o rechazar la siguiente hipótesis general: La información de carácter visual resulta subsidiaria del procesamiento de la información verbal y requiere, al igual que esta última, de estrategias para su análisis. El desarrollo de estrategias específicas en 
el sujeto lector favorece la comprensión del texto verbovisual. En este orden de ideas se proponen tres sub-hipótesis:

> Sub-hipótesis 1. Las claves lingüísticas y las imágenes visuales son partes inseparables de un todo que da paso a procesos de comprensión integrales, complejos y flexibles propios de los textos verbovisuales narrativos.

$>$ Sub-hipótesis 2. Si se intensifica la exposición del sujeto a textos verbovisuales narrativos y participa en la aplicación de estrategias para su procesamiento, se facilitan los procesos de recuperación de conocimiento previo y su uso para la asimilación de estímulos nuevos. A mayor tiempo, frecuencia e intensidad de intervención mayor efecto en el fortalecimiento de los procesos de comprensión de textos verbovisuales.

Sub-hipótesis 3. Los procesos de intervención para la comprensión en su gran mayoría priorizan los códigos verbales, ratificándose la tradición logocentrista y disminuyendo la variabilidad en el procesamiento textual que afecta la habilidad para realizar muestreo, producir inferencias, reflexionar y valorar la información. Adelantar procesos de alfabetización verbovisual proporciona beneficios derivados de la experiencia mediada que se manifiestan en el comportamiento adaptativo de los sujetos y el aumento en el grado de experticia en la comprensión.

\subsubsection{Contraste de la hipótesis}

Con el propósito de explicar desde los planteamientos de la psicolingüística, la incidencia de las claves lingüísticas y la imagen visual en la comprensión de textos 
verbovisuales narrativos como el cuento gráfico, se diseña un experimento en el cual se seleccionan 10 estudiantes en un grupo control y 10 estudiantes de un grupo de estudio. Se aplica una prueba pretest (Anexo 1) en cada grupo; luego se realizan tres monitoreos al grupo intervenido (Anexos 2, 3 y 4); y, finalmente, una prueba post test (Anexo 5) a los dos grupos. Cada prueba está conformada por 10 preguntas de selección múltiple con única respuesta, se califican las últimas y se categorizan en aciertos y desaciertos. El objetivo de utilizar las pruebas pretest y post test es evaluar el efecto del plan de intervención aplicado al grupo de estudio; por su parte, los monitoreos permiten rastrear el proceso de modificación cognitiva propiciado por el uso de estrategias específicas en el sujeto lector necesarias para fortalecer la comprensión del texto verbovisual narrativo.

Para comprobar la hipótesis general los datos se someten a análisis mediante el software estadístico R (Daniel et al., 1997; López-Roldán y Fachelli, 2015). El análisis de resultados (Anexos 8 y 9) y el contraste de la hipótesis se realiza de la siguiente forma:

1. Comparación de proporciones mediante intervalos de confianza, entre grupos y tiempos.

2. Análisis de curvas de aprendizaje de los grupos respecto a las pruebas pretest, post test y monitoreos.

3. Análisis multivariado de correspondencias múltiples para ilustrar el efecto de la intervención teniendo en cuenta cada pregunta y etapa del estudio de manera simultánea.

4. Agrupación de los sujetos según sus resultados mediante un análisis de clúster. 


\subsubsection{Intervalos de confianza para la diferencia de proporciones entre grupos}

Para determinar si existe influencia en las respuestas totales acertadas entre los grupos tratados y entre los tiempos del estudio intervenido, se realizan intervalos de confianza para la diferencia de proporciones mediante la siguiente fórmula:

$$
\begin{gathered}
{\left[\left(\hat{p}_{1}-\hat{p}_{2}\right)-Z \alpha / 2 \sqrt{\frac{\hat{p}_{1}\left(1-\hat{p}_{1}\right)}{n_{1}}+\frac{\hat{p}_{2}\left(1-\hat{p}_{2}\right)}{n_{2}}},\left(\hat{p}_{1}-\hat{p}_{2}\right)\right.} \\
\left.+Z \alpha / 2 \sqrt{\frac{\hat{p}_{1}\left(1-\hat{p}_{1}\right)}{n_{1}}+\frac{\hat{p}_{2}\left(1-\hat{p}_{2}\right)}{n_{2}}}\right]
\end{gathered}
$$

Se reemplazan los valores de proporciones de aciertos en cada comparación, se obtienen los siguientes intervalos de confianza.

$>$ Inicio (Control vs Estudio) $[-0.1485791 ; 0.1285791]$

Notando que el intervalo contiene al cero, por lo que no hay diferencias entre las proporciones de aciertos en las 10 preguntas para la etapa de inicio. Así, de manera general los grupos control y estudio poseen significativamente el porcentaje de respuestas correctas. Siendo los grupos estandarizados.

> Final (Control vs Estudio) [-0.3517143; -0.08828567$]$

Se nota que los límites son negativos en ambos lados, por lo que existe diferencia entre las proporciones de respuestas correctas en total para la etapa final. 
En particular hay mayor proporción de respuestas correctas para el grupo estudio frente al control. Manifestando el efecto positivo en la intervención del grupo tratado.

> Monitoreo E1 vs Monitoreo E2 $[-0.2461742 ; 0.02617416]$

Se tiene que contiene a cero, por lo que no hay diferencia entre el porcentaje de respuestas correctas en el grupo estudio en la etapa monitoreo 1 frente al monitoreo 2 . Así, de manera general no se tiene efecto positivo entre la etapa monitoreo 1 y la etapa monitoreo 2.

$>$ Monitoreo E1 vs Monitoreo E3 [ $-0.331656 ;-0.06834401]$

Se nota que el intervalo es de valores negativos, y esto indica que existen diferencias significativas entre la proporción de respuestas correctas del grupo tratado en la etapa del monitoreo 1 frente al 3. En particular el efecto es positivo, ya que la proporción de respuestas correctas en la etapa monitoreo 3 es mayor que el monitoreo 1.

> Monitoreo E2 vs Monitoreo E3 [-0.2192263; 0.03922629]

Finalmente, comparando la etapa de monitoreo 2 frente al monitoreo 3 , se nota que el cero queda incorporado en el intervalo de confianza, por lo que no hay diferencia en la proporción de respuestas correctas. Es decir, de manera general, no hay un cambio entre la etapa monitoreo 2 y monitoreo 3 , pero si del monitoreo 1 al 3 . 


\subsubsection{Análisis de curvas de aprendizaje}

Las curvas de aprendizaje se utilizan para medir la rapidez con que una habilidad se puede dominar en función del tiempo que se necesita para aprender una nueva tarea o conjunto de habilidades, versus la velocidad a la que se alcanza la especialización total. Es decir, se evalúa el progreso de un individuo frente a un promedio, se muestran los triunfos obtenidos en relación a ese tiempo. Se parte de la idea que en la medida en que los sujetos aprenden nuevos procedimientos o mejoran las técnicas que utilizan, pueden obtener mejores resultados en sus tareas, tener un mayor rendimiento implica que las situaciones de estímulo deben a sí mismo estar evolucionando constantemente en lugar de simplemente repetir. Permiten evaluar el rendimiento obtenido y planificar en base a los efectos del aprendizaje (Schilling et al., 2003).

En la investigación se emplean curvas de aprendizaje grupales e individuales. Las primeras, describen el aprendizaje en grupo de los procesos a partir del promedio de aciertos en las pruebas aplicadas. Al respecto Glock y Jaber (2014) afirman que el aprendizaje grupal es más que una agregación de los procesos de aprendizaje individual, es la confirmación de la transferencia de conocimiento entre los individuos, en conjunto. Las segundas, corresponden al registro del desempeño del sujeto que se deriva de la relación entre conocimiento previo y el conocimiento nuevo vinculado a la tarea que se demanda y al tiempo que invierte, además, la tasa de progreso depende en parte de la velocidad de los procesos mentales y los estados anímicos del sujeto (Schilling et al., 2003). 


\subsection{Curvas de aprendizaje grupales, grupo control y grupo de estudio}

Partiendo de las respuestas acertadas en las pruebas pretest y post test por parte de los sujetos del grupo control surge la curva de aprendizaje sin evidente crecimiento (Figura 22). El puntaje inicial alcanzado es de 5 y el final de 5,1, es decir, el aumento en el desempeño es poco significativo.

Figura 22

Curva de aprendizaje. Grupo control

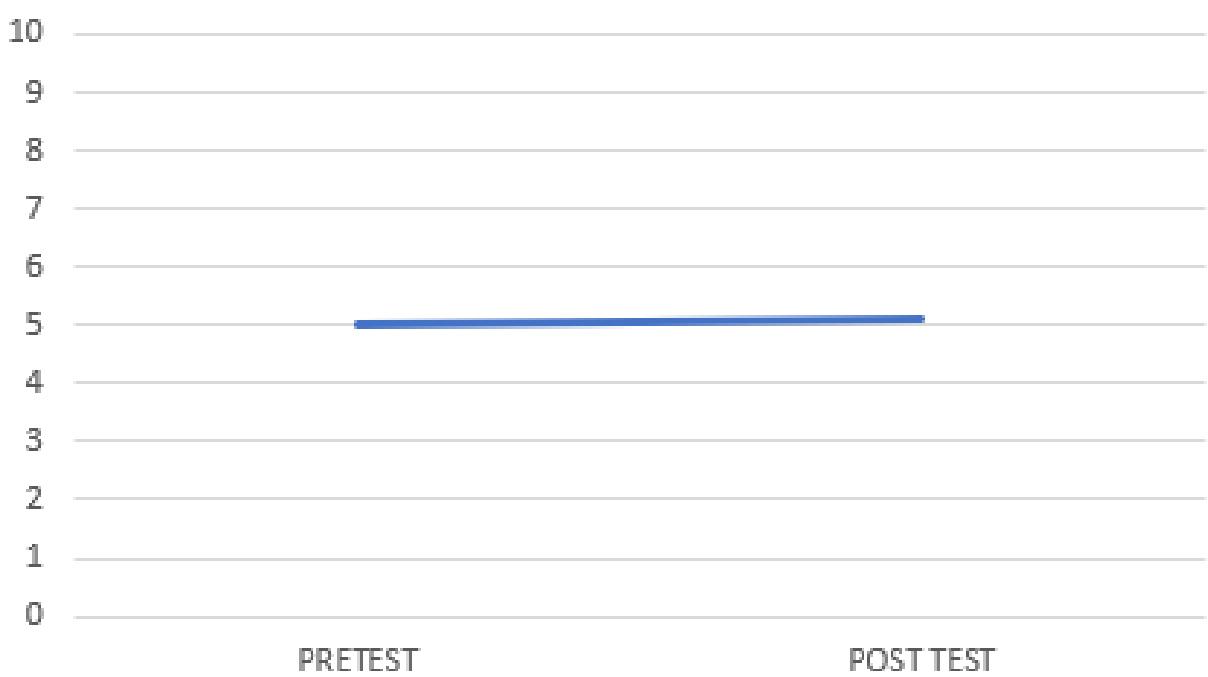

Tal como lo muestra la figura 23, el grupo de estudio alcanza un puntaje inicial de 5,0 y final de 8,0. La curva exhibe en la etapa preliminar de crecimiento poco avance, los sujetos requieren mayor tiempo y esfuerzo para aprender nuevas habilidades y el manejo de las mismas, lo que retarda el efecto del dispositivo. Posteriormente en los monitoreos se muestra un incremento sustancial y constante. Finalmente, en la última etapa el crecimiento empieza a ralentizarse, que puede deberse al aumento de la complejidad de las tareas y la exigencia sobre el uso de lo 
aprendido. Se espera que con más tiempo de intervención los sujetos puedan estabilizarse y la tendencia al crecimiento nuevamente se active, es decir, la curva de aprendizaje sea exponencial.

Figura 23

Curva de aprendizaje. Grupo estudio

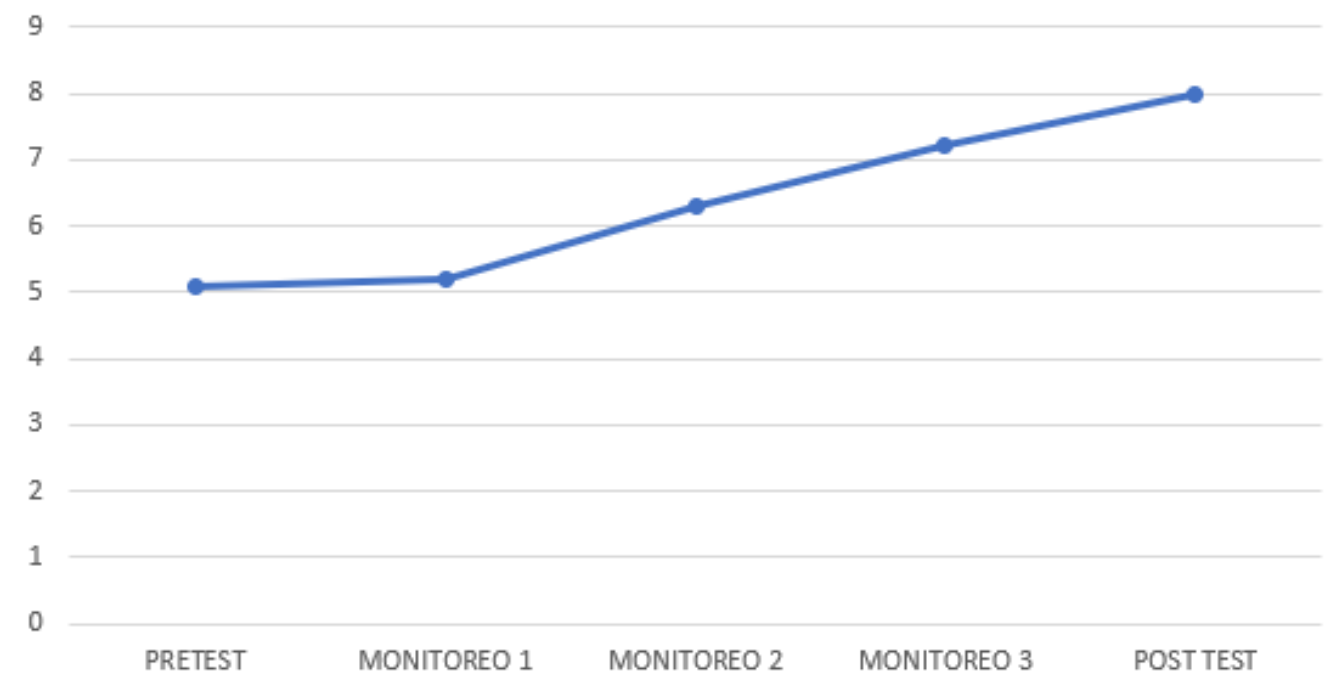

Al comparar las curvas de aprendizaje del grupo estudio frente al grupo control se observa que en el momento 1 (prueba pretest) el puntaje alcanzado es de 5,0 para ambos casos. En el transcurso de la intervención el desempeño del grupo control casi no presenta modificaciones, la curva se mantiene sin evolución; por su parte, el desempeño del grupo estudio es positivo, la curva crece de forma exponencial. En el momento 2 (prueba post test) el puntaje final del grupo control es de 5,1 y del grupo estudio 8,0. Entonces, se puede distinguir diferencias significativas, ratificándose el efecto acumulativo del aprendizaje y el impacto de la intervención. 


\subsubsection{Curvas de aprendizaje individuales, grupo control y grupo de estudio}

Las curvas de aprendizaje individuales del grupo control (Figura 24) revelan irregularidades en los desempeños. Los sujetos 4,5 y 10 incrementan sus aciertos; los sujetos 1, 6 y 8 mantienen igual su promedio de respuestas acertadas; los sujetos 2, 3, 7 y 9 disminuyen el número de aciertos. Lo expresado ratifica que los organismos humanos aprenden naturalmente, los estímulos aleatorios generan una suerte de posibilidades no sistemáticas. Por otra parte, la exposición a experiencias de aprendizaje mediado intensifica el fortalecimiento de las habilidades gracias a la selección de estímulos según una intencionalidad, una trascendencia y un significado.

\section{Figura 24}

Curva de aprendizaje por sujeto. Grupo control
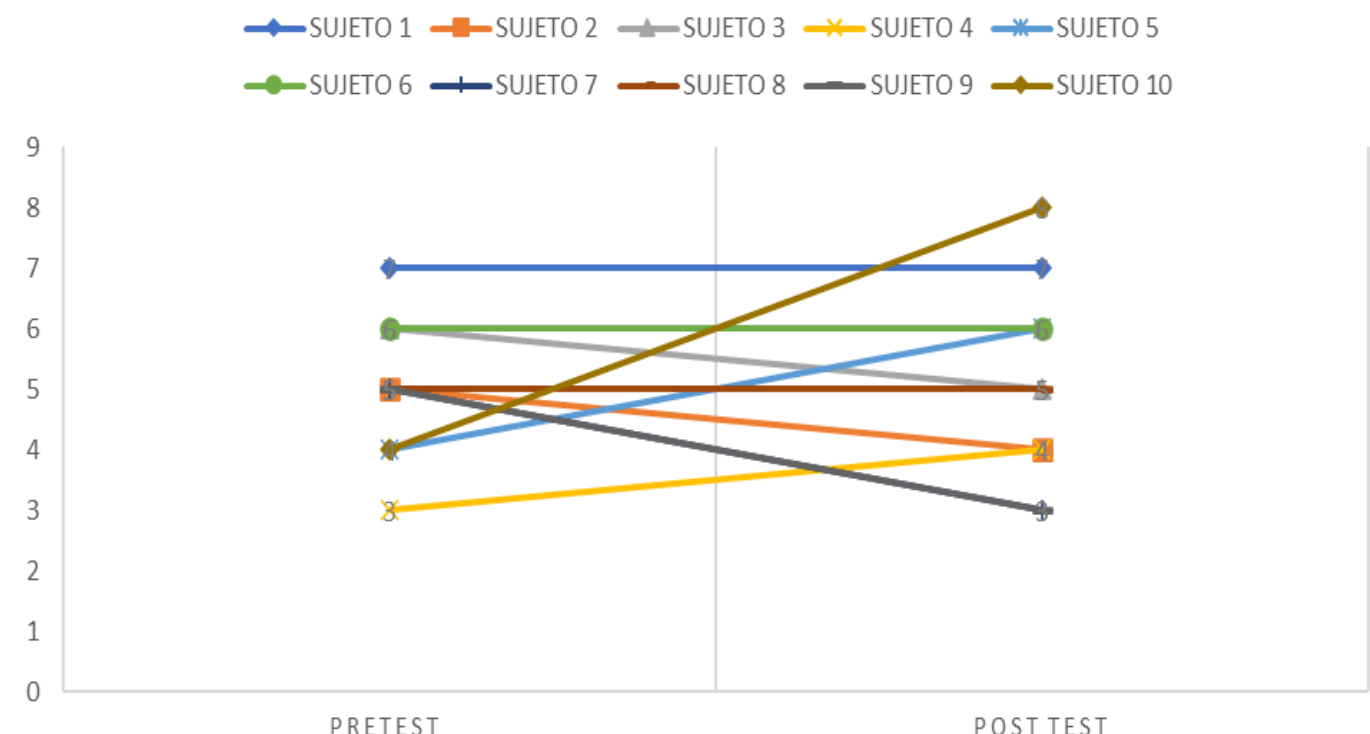

Las curvas de aprendizaje individuales del grupo estudio (Figura 25) permiten aglutinar los sujetos en tres subgrupos teniendo en cuenta su desempeño. En el primero se encuentran los sujetos 1, 2, 3, 6, 8, 9 y 10, su constante es que avanzan en 
sus procesos de forma contundente, no siempre al mismo ritmo y con igual resultado; algunos muestran retrocesos leves al principio o al final de los monitoreos, otros se destacan más en los monitoreos que en las pruebas pretest y post test o viceversa. El subgrupo dos está conformado por el sujeto 4, progresa hasta la mitad del proceso y luego retrocede sin cambios destacables, el aprendizaje no es constante y se detiene. El subgrupo tres se compone por los sujetos 5 y 7, avanzan mínimamente entre cada una de las pruebas, sus cambios son imperceptibles y poco significativos.

\section{Figura 25}

Curva de aprendizaje por sujeto. Grupo estudio

$\rightarrow$ Sujeto $1 \rightarrow$-Sujeto $2 \multimap$ Sujeto $3 \multimap$ Sujeto $4 \rightarrow$ Sujeto 5

$\rightarrow$ Sujeto $6 \longrightarrow$-Sujeto $7 \longrightarrow$ Sujeto $8 \longrightarrow$ Sujeto $9 \rightarrow$ Sujeto 10

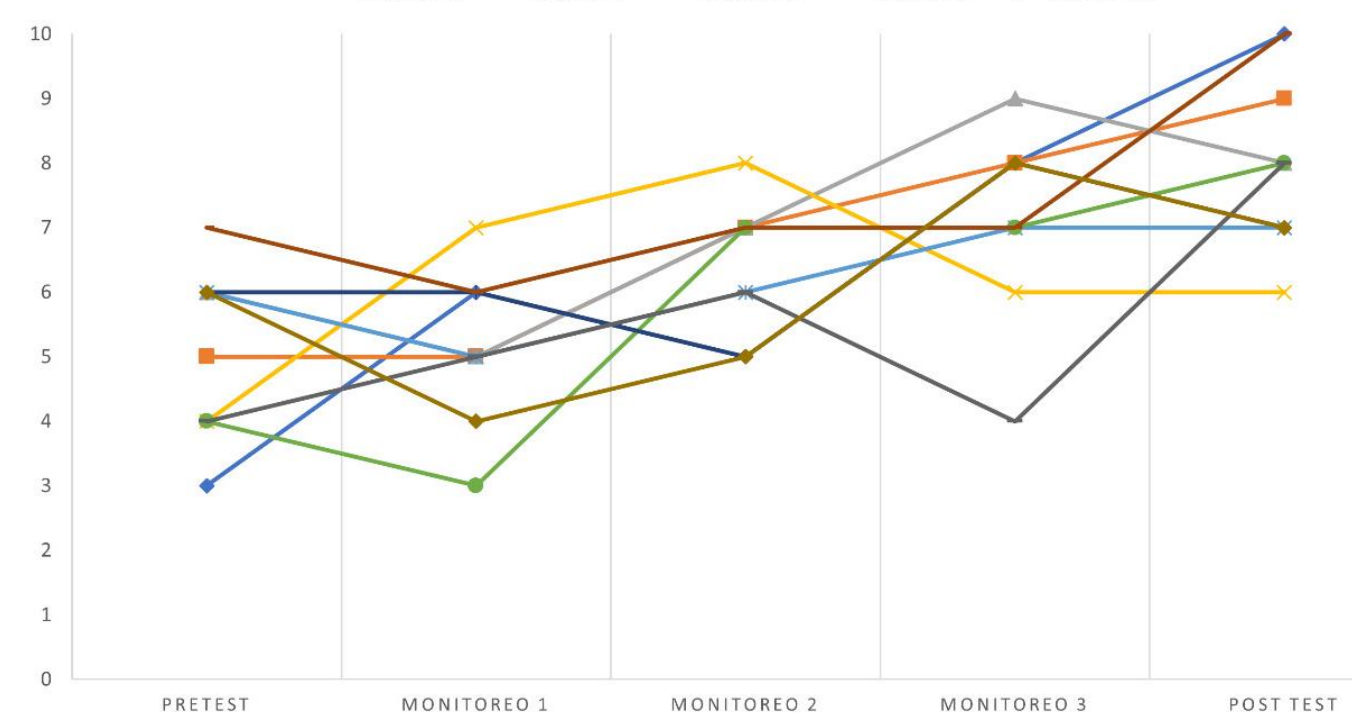

\subsubsection{Análisis multivariado}

Las técnicas estadísticas multivariadas permiten establecer, a partir de numerosos datos y variables, ciertas relaciones, investigar estructuras latentes y ensayar diversas maneras de organizar dichos datos para socializar resultados. El 
análisis multivariante siempre se utiliza cuando hay más de tres variables involucradas y el contexto de su contenido no está claro. El objetivo es detectar una estructura, por un lado, y verificar los datos de las estructuras por otro (Siegel,1995; Fuentes, 2011). En la presente investigación se hace un análisis multivariado de conglomerados clúster, con el objetivo de dar cuenta de las correspondencias múltiples para ilustrar el efecto de la intervención teniendo en cuenta cada pregunta y etapa del estudio de manera simultánea, así como del impacto o distancia en los momentos de la intervención a partir de los indicadores.

En la figura 26 de la prueba pretest se observan las características del grupo estudio y control. Notando las tendencias de las formas de responder cada pregunta. Cuando los estudiantes responden con desaciertos en la pregunta 8, tienden de manera general a responder también en desacierto la pregunta 7 y la pregunta 9 , es decir, hay una tendencia a acertar o desacertar en un mismo número de preguntas. En el gráfico, además, se puede observar que tanto el grupo control como el grupo estudio están estandarizados, es decir, que son comparables debido a que tienen características comunes y su desempeño es negativo ubicándose en el área inferior del plano factorial. 


\section{Figura 26}

Pretest, plano factorial simultáneo

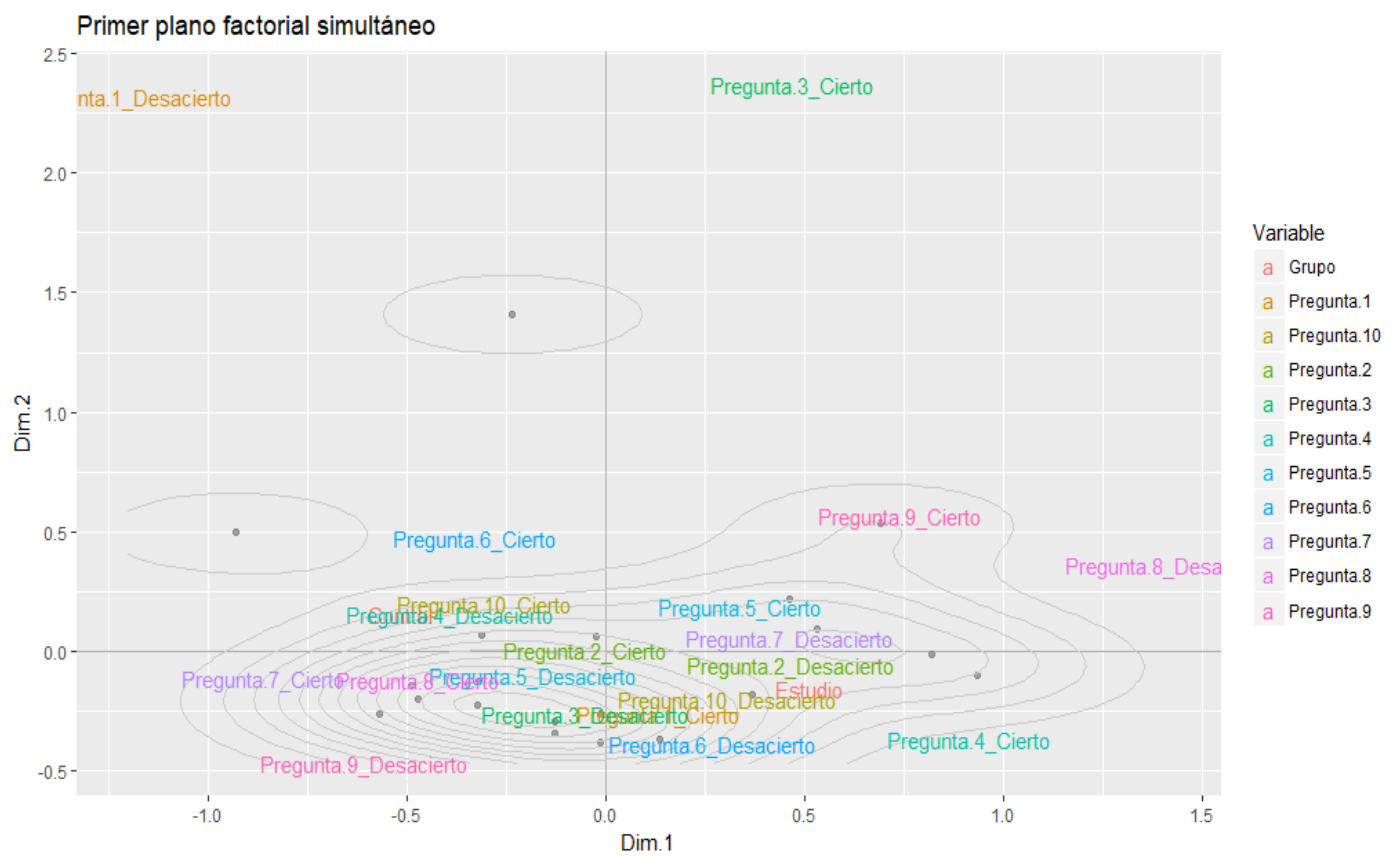

En la figura 27 del monitoreo 1 se observa que los sujetos responden desaciertos en la pregunta 2 y 4 o correctamente las preguntas 7,8 y 9 . Partiendo de las respuestas se puede evidenciar que los grupos empiezan a extenderse en el plano y a obtener un desempeño positivo al desplazarse hacia arriba. 


\section{Figura 27}

Monitoreo 1, plano factorial simultáneo

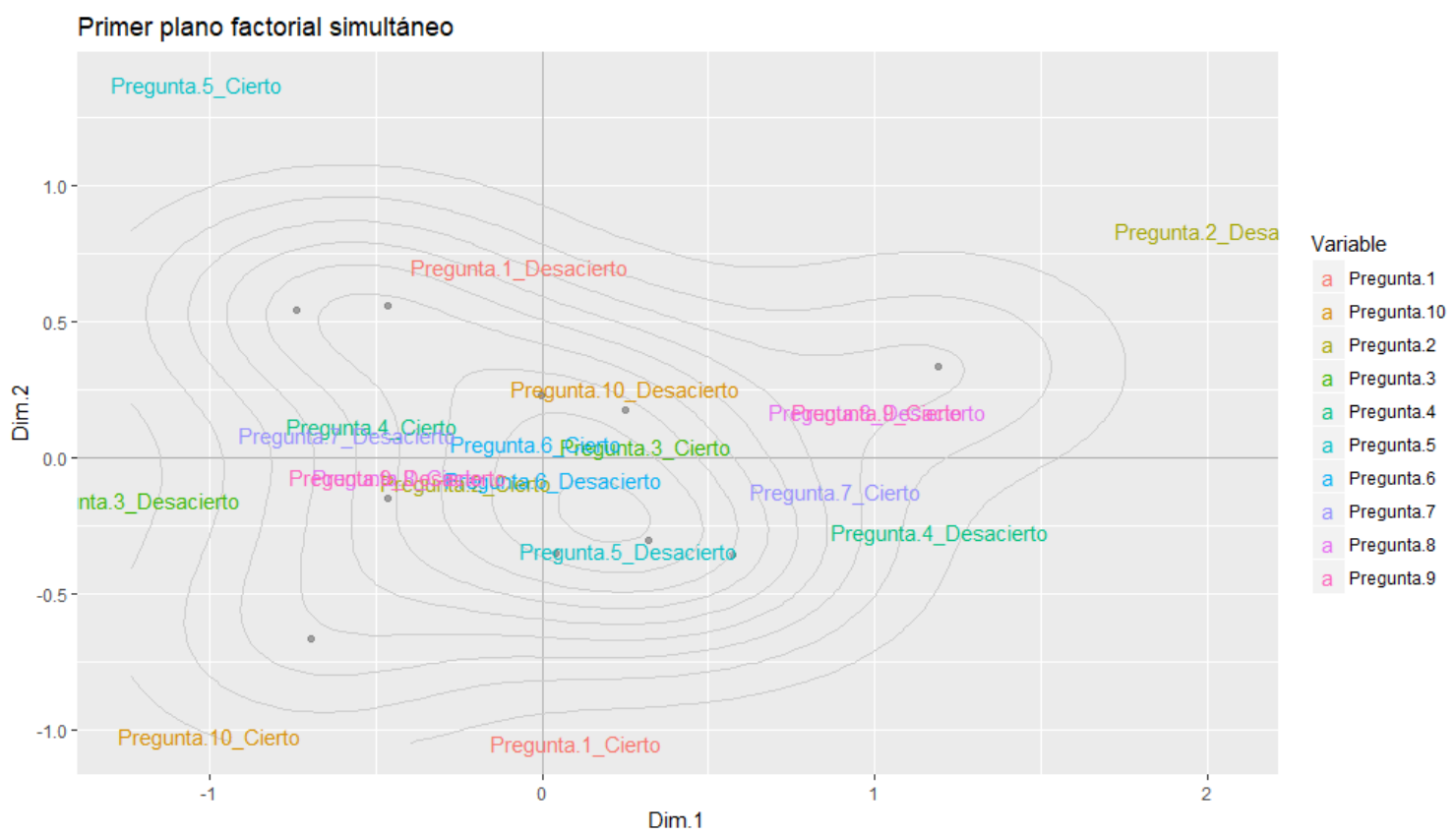

En la figura 28 del monitoreo 2 se observa que los sujetos responden con desaciertos las preguntas $9,4,10$ y 6 . Partiendo de las respuestas se puede evidenciar que los grupos empiezan a extenderse con mayor contundencia en el plano y a obtener un desempeño positivo al desplazarse hacia arriba. 


\section{Figura 28}

Monitoreo 2, plano factorial simultáneo

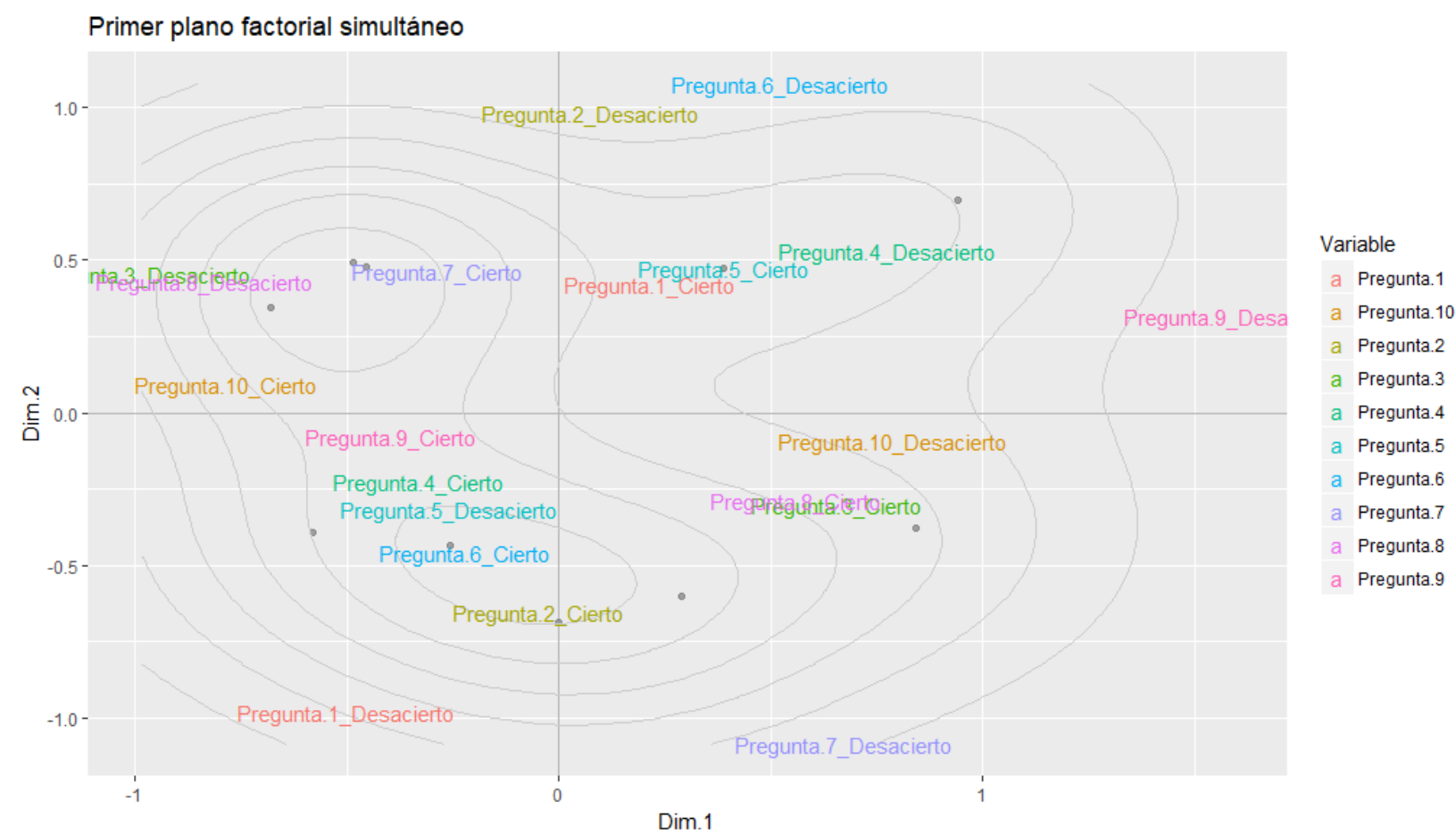

En la figura 29 del monitoreo 3 se observa que los sujetos que responden con desaciertos la pregunta 3 se caracterizan porque también lo hacen en las preguntas 1 y 5. Partiendo de las respuestas se puede evidenciar que los grupos al extenderse en el plano muestran que su desempeño es positivo al desplazarse hacia arriba. 


\section{Figura 29}

Monitoreo 3, plano factorial simultáneo

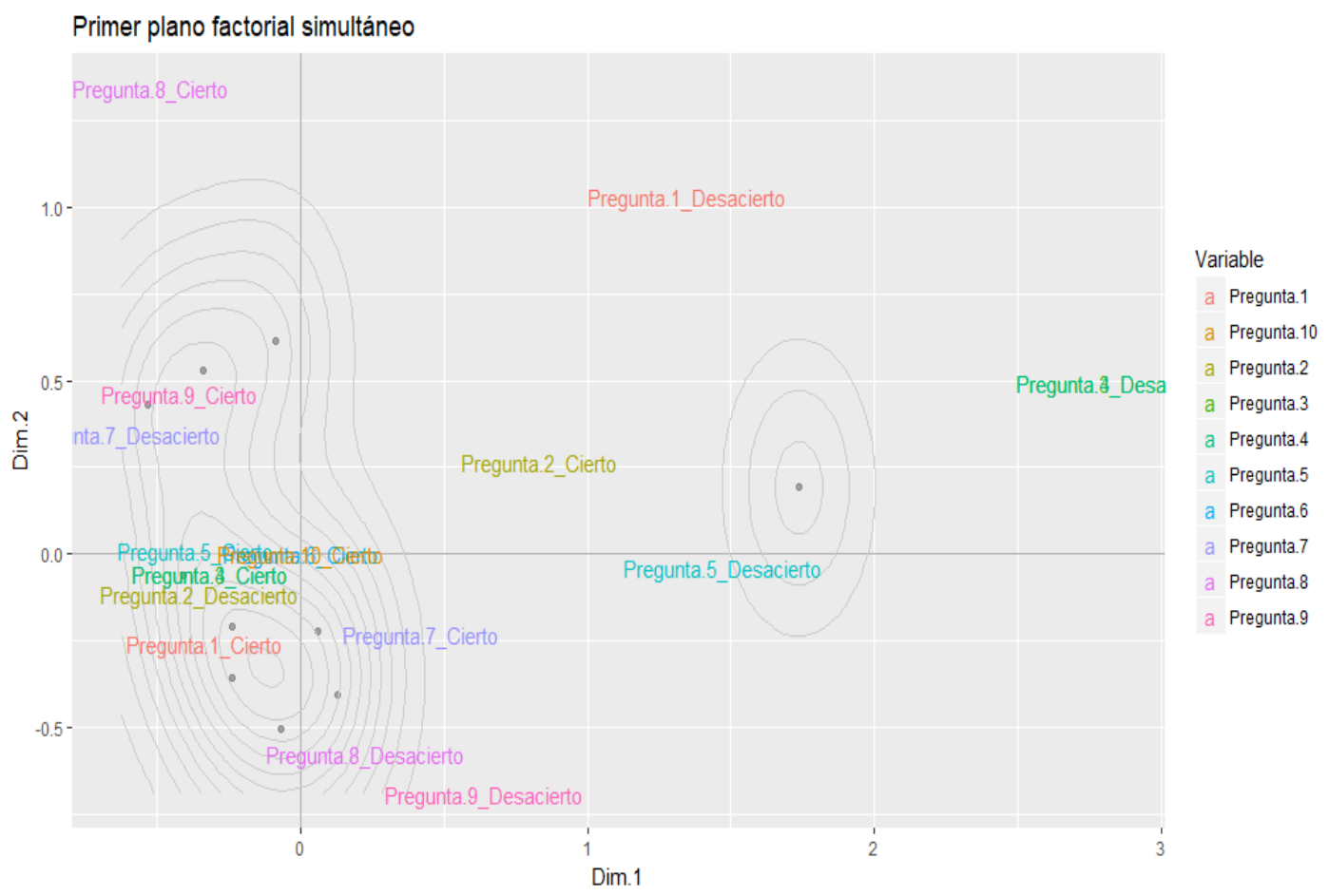

En la figura 30 de la prueba post test se nota el efecto de la intervención debido que el grupo estudio y control se encuentran en lugares diferentes del plano. La tendencia del grupo control es hacia los desaciertos ubicados en lugares lejanos evidenciando diferencias como grupo. Por su parte el grupo estudio tiene tendencia a los aciertos, sus respuestas se ubican en puntos cercanos mostrando propensión a desempeño relativamente parecido como grupo. 


\section{Figura 30}

Post test, plano factorial simultáneo

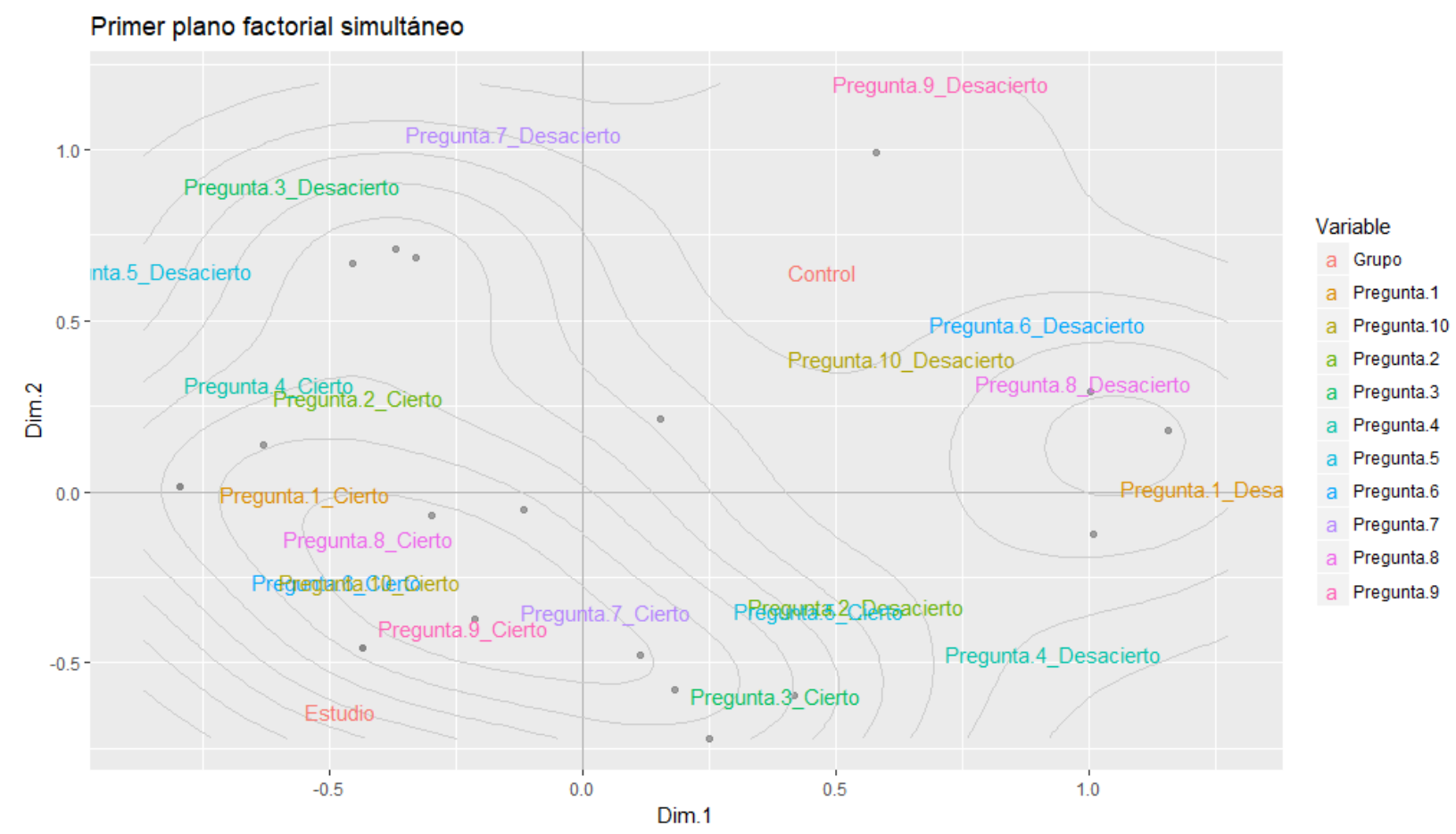

El análisis multivariado de correspondencias múltiples permite ver las distancias en el desempeño de los sujetos de cada grupo que se van marcando de forma paulatina en los diferentes momentos del estudio. En el pretest los sujetos del grupo control y estudio muestran rendimiento equivalente. En los monitoreos el grupo estudio presenta tendencia a la mejora constante. El en post test los grupos se ubican en lugares diferentes del plano, donde el $70 \%$ de los sujetos de estudio se consolidan como grupo y presentan avances en el procesamiento de la información textual evidente en su aglutinamiento hacia arriba en el centro-izquierdo; los sujetos del grupo control casi no se desplazan de la misma zona del plano factorial del momento pretest al post test, demostrando poco crecimiento generado por razones fortuitas. Aunque el 
tiempo de intervención es bajo, se tuvo mejoras considerables, lo que permite proyectar resultados más contundentes con un incremento en el tiempo de aplicación.

\subsubsection{Análisis de Clúster}

En el análisis clúster se clasifican a los sujetos de estudio en conglomerados para identificar la homogeneidad o heterogeneidad entre ellos (Siegel,1995; Fuentes, 2011).

En las figuras 31 y 32 los objetos similares se conectan mediante enlaces cuya posición está determinada por el nivel de similitud/disimilitud entre los objetos. Todas estas agrupaciones se toman en función de la similaridad multivariante (o de su contrario, la distancia), cada nivel de jerarquía se une en clústers más cercanos (Fuentes, 2011).

En la figura 31 se observan las agrupaciones de los sujetos teniendo en cuenta las similitudes de la forma de responder cada pregunta. Resaltando que hay similitudes en los sujetos del grupo estudio (numerados de 1 a 10) y el grupo control (numerados de 11 a 20). En particular el sujeto 11 es muy diferente a los demás en cuanto a sus respuestas, por tanto, no forma clúster con ningún otro sujeto. La figura permite evidenciar que los grupos antes de la intervención no presentaban diferencias respecto a los procesos de comprensión y tenían aislamiento externo. 


\section{Figura 31}

Pretest, clúster

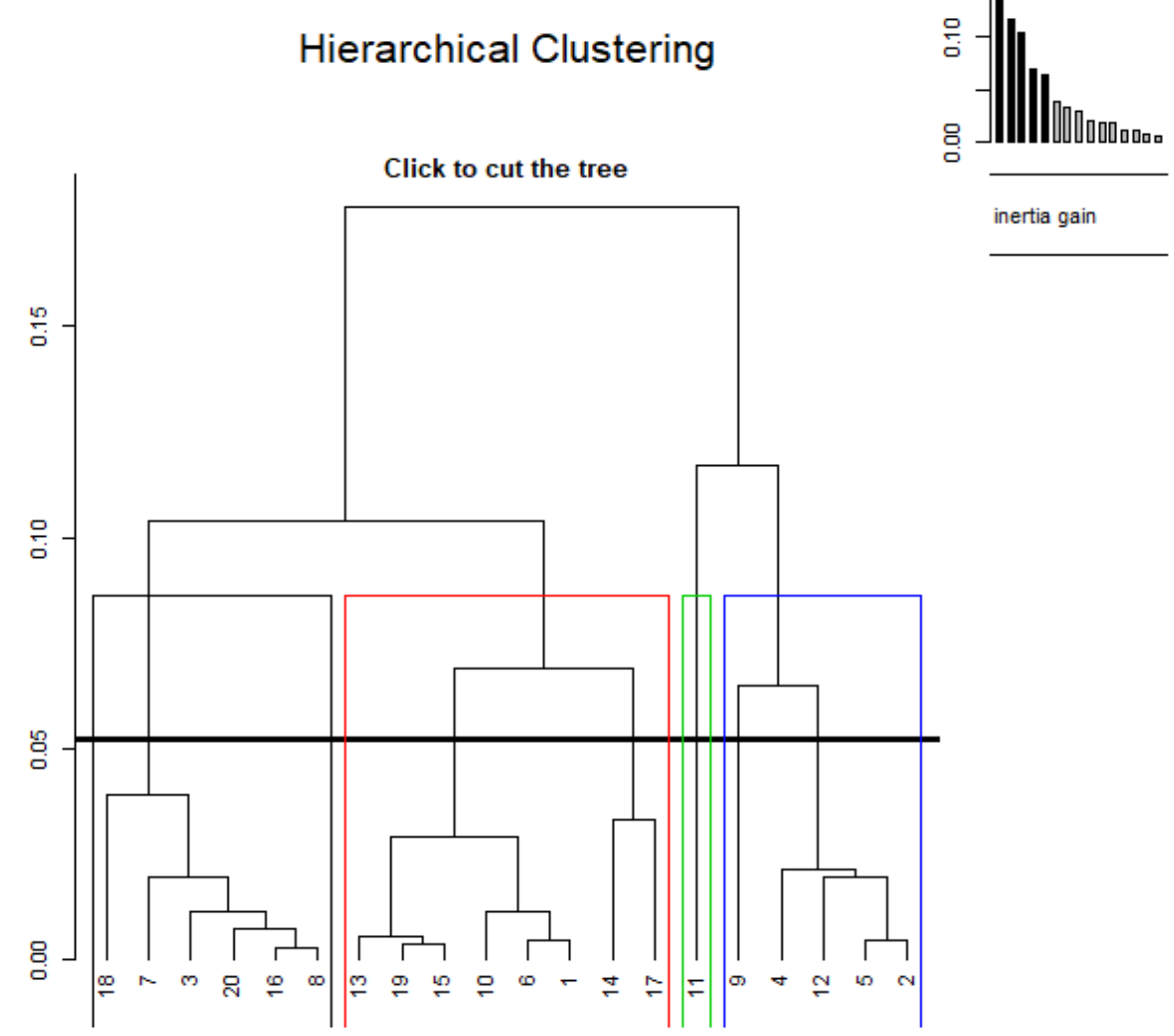

Considerando los resultados de la prueba Clúster representados en la figura 32 , de acuerdo con la inercia de ganancia con corte al 0,10 de las distancias, se observa que los sujetos del grupo de estudio se ubican en su gran mayoría hacia la derecha y forman clúster entre ellos, evidenciando cohesión interna como grupo. Lo expuesto confirma el avance como grupo y que el proceso de experiencia de aprendizaje mediado impacta positivamente en un $70 \%$ de los sujetos de estudio, tal como se corrobora en el análisis multivariado de correspondencias múltiples desde el desempeño de los sujetos en los momentos de la intervención. 
Figura 32

Post test, clúster

Hierarchical Clustering
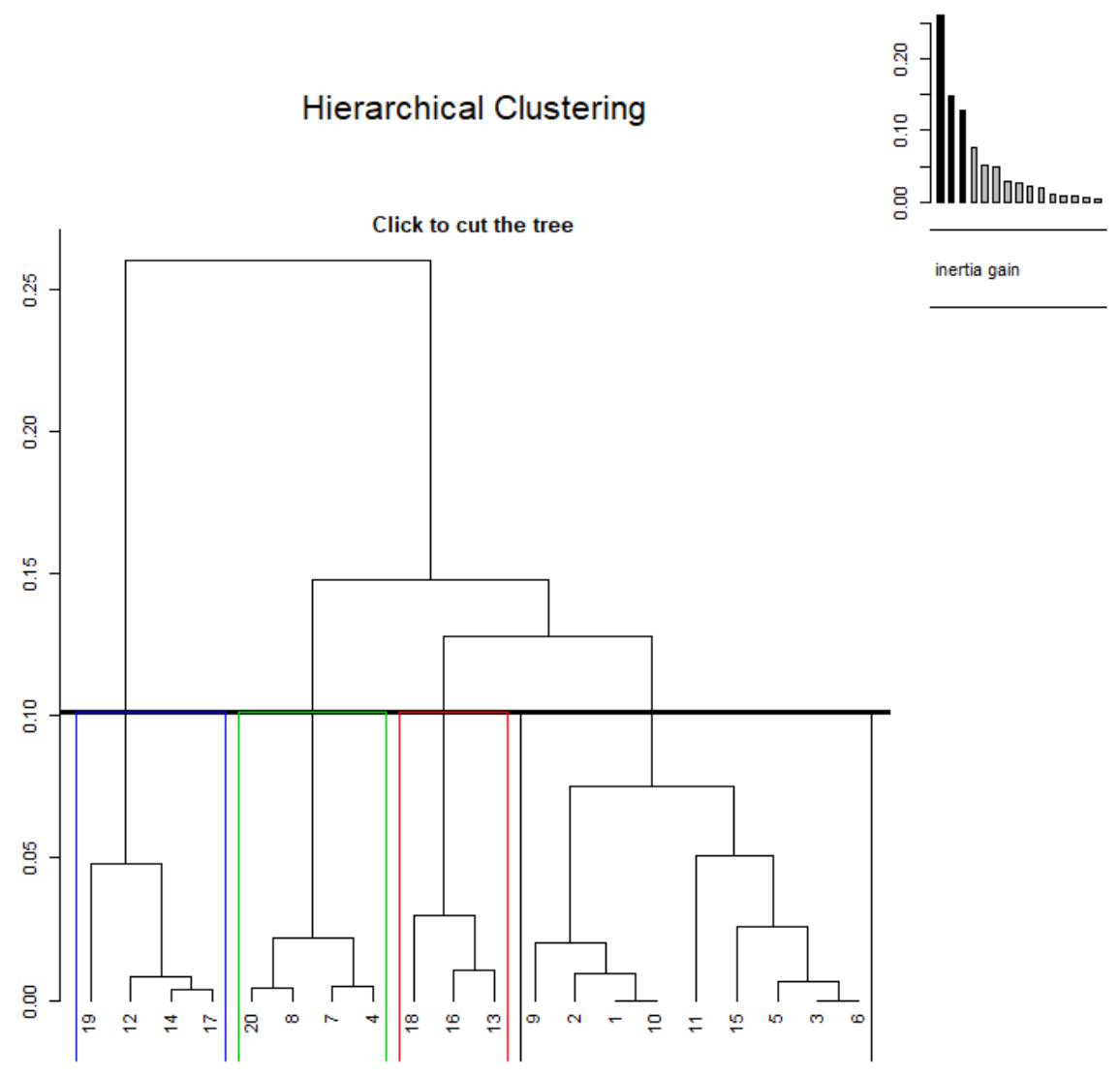

\subsection{RECAPITULACIÓN}

Las respuestas a la prueba pretest permiten confirmar que los sujetos están estandarizados, es decir, son comparables porque no presentan diferencias estadísticas en su desempeño en la comprensión de textos verbovisuales narrativos y pueden recibir de forma indistinta el tratamiento que se diseña. Por su parte, las respuestas de la prueba post test permite establecer diferencias sustanciales entre el grupo control y el grupo estudio, puesto que el último incrementa las respuestas acertadas demostrando la eficacia de la intervención. Tales hallazgos se corroboran con el análisis multivariado. 
En el monitoreo 1 se identifica la prevalencia de los desaciertos sobre los aciertos. En el monitoreo 2 se incrementan los aciertos y disminuyen los desaciertos. En el monitoreo 3 hay una preeminencia de los aciertos sobre los desaciertos. Por tanto, partiendo de las respuestas de los sujetos del grupo estudio, se puede identificar la tendencia a mejorar el desempeño en la comprensión.

A partir de los intervalos de confianza se corrobora que los grupos de estudio y control al inicio de la intervención son estandarizados. No se presentan diferencias en los resultados del grupo de estudio entre el monitoreo 1 y monitoreo 2 o entre el monitoreo 2 y el monitoreo 3, pero si hubo incrementos a favor de los aciertos en las pruebas de comprensión del monitoreo 1 frente al monitoreo 3. Se puede establecer que, si se aumentan las sesiones con sus actividades y las pruebas de monitoreo para su seguimiento, los resultados podrán ser mucho más contundentes y el margen de éxito aumentaría, logrando un avance constante y sustancial a largo plazo.

Las curvas de aprendizaje manifiestan la progresión geométrica, consecuencia de la reiterada experiencia del aprendizaje mediado (Schilling et al., 2003). Es decir, se presenta la práctica acumulativa en tareas específicas, por lo que se supone que la tasa de aprendizaje se maximiza mediante la dedicación en actividades concebidas desde estructuras de aprendizaje, contenidos aprendidos, propensión a aprender y beneficios de situaciones de aprendizaje (Feuerstein, 1990). Lo expresado se demuestra en el incremento en el desempeño de los sujetos 1, 2, 3, 6, 8, 9, 10; progreso hasta la mitad de la intervención del sujeto 4; y poco o ningún avance de los sujetos 5 y 7 . 
La prueba clúster permite comparar la prueba pretest y la prueba post test en los grupos control y de estudio conformando conglomerados jerárquicos que muestran el aumento del porcentaje de respuestas acertadas en el grupo motivo de estudio. Se logra avanzar significativamente en su constitución como un grupo con cohesión interna y parcialmente homogéneo gracias al incremento en su desempeño en la comprensión.

Realizando un análisis comparativo de los resultados de la prueba pretest y post test se puede afirmar que en el grupo de estudio se muestran avances en los procesos de comprensión de textos verbovisuales narrativos respecto al grupo control, tomando como evidencia el incremento de los aciertos en cada pregunta y el aumento del desempeño en $1 \%$ en el grupo control y $29 \%$ en el grupo motivo de estudio. En cuanto a los monitoreos se observa un avance constante, lo que prueba el efecto positivo de la intervención en el incremento de los procesos en la comprensión de textos narrativos verbovisuales como los cuentos gráficos.

Ahora bien, la participación de los 20 sujetos en la investigación es voluntaria y su distribución en los grupos control y de estudio se realiza al azar, la selección de una muestra pequeña permite el seguimiento de los sujetos y el análisis profundo de los comportamientos verbales. Los sujetos resuelven preguntas de comprensión de complejidad creciente para cada una de las etapas; en ellas se indaga sobre la información textual en cuanto al reconocimiento y análisis de los aspectos denotativos, connotativos y conceptuales de la imagen visual, y el reconocimiento y análisis de los aspectos microestructurales, superestructurales, macroestructurales en los textos partiendo de las claves lingüísticas. Así mismo, la acción de comprender exige 
recuperar información (muestro), producir de inferencias (predicción, anticipación, confirmación y autocorrección), reflexionar y evaluar la información.

Tal como se establece en párrafos anteriores, el grupo control no manifiesta avances en la comprensión, aunque sus conocimientos previos y la exposición a textos verbovisuales es parcialmente igual al de los sujetos del grupo estudio. Recuérdese que los sujetos investigados son estudiantes de la Licenciatura en Español y Literatura, lo que les exige realizar actividades frecuentes de lectura de documentos y acceso a diferentes títulos de literatura, lo cual asegura procesos de comprensión en constante consolidación y marcos de referencia dinámicos. Entonces, se ratifica el impacto del dispositivo diseñado que posibilita la experiencia de aprendizaje mediada del grupo estudio, ocasionando el fortalecimiento del comportamiento asimilativo y adaptativo que lleva a los sujetos a regular sus respuestas cognitivas dependiendo de las tareas. Se controla la variable independiente mediante un tratamiento experimental que ejerce un efecto directo sobre la variable dependiente.

El análisis cuantitativo permite apreciar las diferencias entre los grupos. Teniendo en cuenta los puntajes alcanzados en las medidas repetitivas y su graficación en curvas de aprendizaje, del momento pre test al post test 3 sujetos del grupo control muestran progresos en su comprensión, 3 permanecen igual y 4 disminuyen sus aciertos. Tal resultado es independiente a la investigación y sus razones son aleatorias puesto que los sujetos no son objeto de seguimiento. Por su parte, en el grupo estudio 7 sujetos acrecientan su rendimiento, 1 demuestra adelantos hasta la mitad de la intervención y luego se ralentiza, 2 avanzan mínimamente. Lo expresado se corrobora con el análisis de Clúster, en el momento pre test los conglomerados son 
indeterminados, es decir, se agrupan independiente a la pertenencia o no a un grupo. En el momento post test 7 de los 10 sujetos del grupo de estudio se aglutinan al lado derecho de la figura 32, lo que demuestra avances en la modificabilidad de su comprensión. Finalmente, el análisis multivariado da cuenta de cada uno de los momentos de la intervención, mostrando que los procesos de los sujetos experimentan incrementos y decrementos mínimos, comportamiento típico en el aprendizaje medido, la diferencia radica en las decisiones y ajustes a partir de los hallazgos.

Entonces, desde el análisis estadístico se confirma la hipótesis general: La información de carácter visual resulta subsidiaria del procesamiento de la información verbal y requiere, al igual que esta última, de estrategias para su análisis. El desarrollo de estrategias específicas en el sujeto lector favorece la comprensión del texto verbovisual. 


\section{CAPÍTULO 5}

HALLAZGOS DESDE LO

CUALITATIVO 


\subsection{INTRODUCCIÓN}

El análisis cuantitativo presentado en el capítulo 4 permite comprobar la validez de la hipótesis de investigación: La información de carácter visual resulta subsidiaria del procesamiento de la información verbal y requiere, al igual que esta última, de estrategias para su reconocimiento. El desarrollo de estrategias específicas en el sujeto lector favorece la comprensión del texto verbovisual.

Ahora bien, en el presente capítulo se comparte el análisis cualitativo de los datos recopilados en el proceso de intervención y vistos a la luz de los aspectos abordados en los capítulos 1 y 2 . Con el objetivo de explicar, desde los planteamientos de la psicolingüística, la incidencia de las claves lingüísticas y la imagen visual en la comprensión de textos verbovisuales narrativos como el cuento gráfico, se describe el proceso realizado por los sujetos de estudio cuando comprenden textos narrativos verbovisuales, se compara y se analiza la relación de las claves lingüísticas y la imagen visual en la comprensión de los mismos. Para lograr lo expuesto, se estudian los desempeños de los sujetos respecto a distintas tareas, se confrontan los indicadores de la variable dependiente en correspondencia con los indicadores de la variable independiente.

\subsection{MODIFICABILIDAD EN LA COMPRENSIÓN}

Leer no implica comprender, se necesita disposición del que lee y apoyo pedagógico. Leer es el resultado de la relación entre conocimientos y experiencias previas, competencia lingüística, información del texto e información del contexto, esquemas (estructuras cognitivas existentes) y modelos mentales (resultado de la 
relación entre ideas). El autor distribuye una cierta cantidad de palabras organizadas según las normas del sistema de la lengua en uso y sus propósitos. Por su parte, el lector identifica intenciones y construye la macroestructura textual por medio del establecimiento de las relaciones entre la cantidad de información presentada, sus estructuras intrínsecas y las limitaciones espaciales; así, mientras lee, construye un texto paralelo y relacionado con el texto original.

El éxito del proceso de comprensión depende de las estrategias de selección de información usadas para determinar cuáles datos se transferirán a la memoria a largo plazo. Con las estrategias cognitivas de selección se realiza una lectura superficial del texto, en la que se incluye el escaneo rápido de datos y la lectura para atender aspectos de la información o para identificar el significado de palabras. Con las estrategias cognitivas generativas se procesa profundamente la información. El lector, gracias a estas estrategias puede elegir adecuadamente la información que estará activa en la memoria de trabajo para no provocar sobrecargas que pueden generar una mala comprensión de lo leído.

En el presente capítulo se comparte el análisis y la interpretación de los datos cualitativos recolectados en el marco de la intervención. Se da cuenta del proceso adelantado por los sujetos de estudio cuando comprenden textos narrativos verbovisuales, para ello, se describe, se compara y se analiza el procesamiento de las claves lingüísticas y la imagen visual. Se parte de la premisa que el sujeto puede modificar la estructura del funcionamiento cognitivo con el fin de adaptarse a las exigencias del medio y las nuevas experiencias. Los cambios deben afectar el todo y 
las partes para alcanzar la permeabilidad, la estabilidad, la permanencia y la autorregulación (Feuerstein, 1990).

\subsubsection{Recuperación de información: el muestreo}

La comprensión de un texto exige que el sujeto localice, seleccione, jerarquice, reúna y revise la información ya sea de aspectos locales o globales. Dichas operaciones de reconocimiento son fundamentales para las etapas posteriores de procesamiento (Valle et al., 1990; De Vega y Cuetos, 1999).

Al leer los cuentos gráficos los sujetos 5 y 7 priorizan un alto porcentaje de las claves lingüísticas, dejan de lado la interpretación de las imágenes visuales, evidenciando el peso de la tradición logocentrista en la lectura. Los sujetos 3, 4 y 10 se enfocan en las imágenes visuales y después se centran en las claves lingüísticas, aunque es un cuento gráfico expresan que las primeras soportan a las últimas. Los sujetos 1, 2, 6, 8 y 9 realizan una lectura alternante, pasan de las claves lingüísticas a la imagen visual de forma fluida, se detienen en algunos elementos claves de los personajes, las onomatopeyas, los planos, las metáforas visuales, los globos que contextualizan.

La sensación es provocada por la excitación espontánea del sistema nervioso central y demanda un proceso instruccional para optimizar el procesamiento textual. Inicialmente se descifran las formas visuales o letras del sistema ortográfico; se contrasta la información textual con la información almacenada en la memoria a largo plazo, de ello depende su decaimiento o recencia y la eficacia de la percepción (Belinchón et al., 1992). En el procesamiento, la dirección visual permite determinar en 
qué trayectoria el ojo percibe la información visual, ayuda a entender la forma cómo se seleccionan y discriminan los estímulos conforme al tiempo, el espacio y los objetos. Dependen directamente de la composición de la imagen y la distribución de los elementos, apoya al proceso de percepción y a la memoria sensorial. Los sujetos realizan acciones de fijación y saltos en elementos específicos. Lo expresado posibilita la superposición de trayectorias rectilíneas propias de los textos monomodales y de trayectorias curvilíneas inherentes a los textos multimodales que exigen movimientos de lectura parabólicos, elípticos y oscilatorios en la superficie bidimensional del texto. Los sujetos en la ruta de dirección visual usan los códigos pictóricos de forma diferente. Los códigos perceptivos los emplean para filtrar la información visualmente atractiva; los códigos espacial para acudir a los planos y el encuadre como herramienta en la construcción de la escena y la secuencia axiológica de la historia; los códigos gestuales para caracterizar el rol de los personajes en la línea argumental; los códigos simbólicos para anclar el texto en los contextos de producción sociocultural; los códigos cromáticos (cuentos en blanco y negro) para vincular el ambiente, la densidad de las acciones y los estados emocionales de los personales; los códigos morfosintácticos para navegar por el texto acudiendo a las características formales; los códigos retóricos para sugerir la intensificación de sucesos y su impacto en la construcción del sentido global. En lo referido al conocimiento y el uso, los códigos perceptivos, espaciales, gestuales, simbólicos y cromáticos presentan mayores facilidades para los sujetos; los códigos morfosintácticos y retóricos muestran avances constantes dado el grado de tecnicidad que implican (Tapia, 2005). 
El reconocimiento de la estructura visual permite al sujeto realizar la conexión de la información de entrada con la ya existente, es decir, inicia el proceso de interpretación mediado por la memoria de trabajo y los conocimientos previos depositados en la memoria permanente. Los sujetos identifican patrones que asumen como ejemplares adecuados de los conceptos que tiene almacenados en la memoria a largo plazo. Inicialmente, adecúan la plantilla, es decir, guardan el estímulo, acceden y comparan la información entrante con la poseída, si se ajusta se reconoce. Después se recurre a archivar los prototipos, que no son copias exactas al estímulo sino abstracciones. Por último, se analizan los atributos o las propiedades perceptivas para encontrar ajuste al concepto (Bruning et al., 2005). En este proceso la atención es esencial porque permite focalizar la energía mental y emplear estrategias de agrupamiento, integración y elaboración.

El texto visual propicia la oportunidad de determinada experiencia para un sujeto productor-intérprete y el nivel visual atiende a la percepción de los receptores sensoriales durante el encuentro con el objeto. Por otra parte, el nivel de la mirada está determinado por la subjetividad y la dimensión de la imagen, la representación y la autorregulación de los imaginarios. La mirada es entendida en el libro como visión modalizada y hecho sociocultural, es decir, que involucra esquemas previamente determinados y, por ende, es particular dependiendo del contexto. Los sujetos crean sus propias rutas de lecturas marcadas por sus expectativas.

Arizpe y Styles (2004) citando a Benson (1986, p.135) afirman que:

[...] Si hablo de qué significa la imagen, traduzco de un sistema simbólico pictórico a uno verbal simbólico. La traducción siempre es inevitable e implica 
transformación y distorsión... la imagen es especial, la imagen como obra artística es la mediación de una idea. Esa idea está envuelta en las cualidades perceptibles de la imagen, las cualidades que así las presenta el artista al espectador para guiar la experiencia a través de caminos determinados. Hablar de la imagen es una mediación posterior. (p. 327).

Los sujetos al inicio priorizan el grado de iconicidad en los textos, dificultando la relación con conceptos. Se solicita la lectura y relectura de los cuentos gráficos, el regreso a viñetas específicas y su análisis a detalle, es decir, la ida y la vuelta al texto para fortalecer el principio de reversibilidad; además, se les pide descomponer los relatos iconográficos en encuadres de diferente magnitud para realizar análisis objetivos, subjetivos y conceptuales. Se acude a la variación de ejemplos, la verbalización de la interpretación a partir de la formulación de preguntas causales y a explicitar el proceso que realizan. Las actividades les permiten emplear y percatarse que existe más de una ruta de procesamiento.

Las tareas de recuperación de información incitan a canalizar la visión de los sujetos, fortalecen la memoria visual, exigen la vinculación de la búsqueda visual con la verbal. Adicionalmente, los sujetos ejercitan el razonamiento hipotético y transitivo. El primero al abstraer los sentidos del texto, al anticiparse a los posibles resultados en la acción narrativa; el segundo al utilizar la información explícita para poder sacar conclusiones, codificar, representar y revertir (Cedillo, 2010). 


\subsubsection{Inferencias: predicción, anticipación, confirmación, autocorrección.}

El diseño de los cuentos gráficos es hipotáctico, es decir, cada imagen, cada viñeta y cada una de las unidades narrativas guardan relación causal con las siguientes, es una secuencia apodíctica o de necesidad mutua. La imagen no es autónoma, se explica en relación de lo que le antecede y sucede, las acciones se encadenan siguiendo consecuencias lógicas intrincadas (Zabala, 2015).

En las diferentes actividades propuestas se pudo identificar que los sujetos 4,5 y 7 tienden a recuperar la información prioritaria del texto, en la mayoría de los casos seleccionan hechos específicos para reproducirlos identificándolos como centrales, aunque realizan procesos inferenciales se muestran dudosos y se les dificulta contrastar información. Los sujetos 1, 2, 3, 6, 8, 9, 10 avanzan en la comparación, el contraste, la asociación, la integración y la generalización que les permite predecir, formular y verificar hipótesis; reconstruyen la idea global del texto, horadan la información implícita y anticipan el final de personajes o hechos que no siempre se muestra directamente en el texto. Para ello, acuden a la cooperación texto-lector, la visualización de lo que se suscita cuando leen, se hacen más conscientes de los gutter de la historia, se interesan por los estados emocionales de los personajes.

Si a los sujetos se les proporciona versiones de los cuentos gráficos con imágenes visuales, tienden a preocuparse por construir la idea global del texto más cercana a la original, mantienen por más tiempo la información recuperada del cuento, aunque experimentan el decaimiento debido a la falta de claves lingüísticas que permiten la repetición y el almacenamiento en la memoria operativa y a largo plazo. Ahora bien, si solo se les permite la lectura de claves lingüísticas se desencadena la 
construcción de ideas globales heterogéneas y relativamente desvinculadas a la propuesta por el texto original, la dificultad para verificar las hipótesis de lectura, las microestructuras no les permiten construir la macroestructura, solo identifican estados anímicos a partir de los enunciados de espaldas a la naturaleza narrativa del texto.

Los sujetos emplean estrategias cognitivas inferenciales selectivas cuando realizan la lectura rápida para identificar el significado de las claves lingüísticas y la imagen visual cuyo fin es cumplir con la tarea, captan de forma acumulativa los datos relevantes. Igualmente, usan estrategias cognitivas generativas cuando elaboran esquemas integradores de la información, resumen, parafrasean, subrayan, discriminan, jerarquizan, comparan-contrastan, proyectan, recuperan, evocan, predicen (McKoon y Ratcliff, 1992). No obstante, tienen dificultad para reconocer que en los cuentos gráficos los personajes determinan la función dramática que cumple el espacio, éste los acompaña, ilustra, refuerza, revela, confirma.

Permanentemente se emplea un suspenso estructural al prolongar la intriga y la resolución del conflicto hasta el final, los cuales son epifánicos o inevitables al verlos en retrospectiva. Las acciones se asocian a una perspectiva general que rebasa el contexto narrativo inmediato, se acompaña de la anagnórisis, es decir, la revelación de una verdad dramática que permite reconocer la auténtica identidad del protagonista (Zabala, 2015). Los sujetos se preocupan por asir los elementos que les facilita la construcción de la idea global del texto, dejando de lado los elementos microestructurales y sus conexiones. Tienen problemas para realizar multitareas: buscar elementos de forma consciente, subrayar según convenciones, conectar datos, superponer líneas argumentales, anticipar acciones, verificar juicios. 
El incremento de la experticia en los procesos inferenciales dados alrededor de los textos verbovisuales narrativos dependen de la agilidad de los sujetos para vincular las claves lingüísticas con las imágenes visuales, de lo contrario la información disponible no es suficiente para construir esquemas mentales que faciliten la posterior recuperación sin decaimiento progresivo. El abandono de la imagen visual a pesar del conocimiento de las características del texto, desestabiliza los procesos de interpretación porque los sujetos saben que los cuentos gráficos poseen imágenes visuales, lo que los conduce a declararlos inconclusos; en consecuencia, deben recurrir a supuestos para completar el sentido global pero no es suficiente.

Es decir, se confirma que "[...] Las imágenes conducen a mayor rendimiento de memoria" (Hardy y Jackson, 2003, 81). Lo anterior, explica que los sujetos que tienen acceso a las imágenes visuales presentan dificultades trascendentales en la recuperación de información y la producción de inferencias ya que las imágenes se constituyen en un pilar para el procesamiento porque funcionan como explicación, permitiendo la activación del conocimiento previo acudiendo a la integración y la generalización de información. Tal como lo afirman Nelson et al. (1976), Bajo (1999), Sierra et al. (1995) en el procesamiento de las palabras inicialmente se accede a la representación léxico-fonológica y después a la representación semántica, por su parte, en el procesamiento de los dibujos se accede directamente a la representación semántica. De tal forma que la información pictórica estimula la elaboración cognitiva, dando lugar a una codificación más extensa en términos de una red semántica más amplia, con mayor número de rutas de acceso, lo cual incrementa la probabilidad de que la información sea recuperada en posteriores tareas. 


\subsubsection{Reflexión y evaluación de la información}

El cuento gráfico se caracteriza por aprovechar recursos como el suspenso estructural, el final epifánico y la anagnórisis. Los sujetos inician su lectura observando el plano general para luego pasar a los detalles, el tono, el contraste entre la luz y la oscuridad, las letras en negrillas. Los elementos visuales crean una atmósfera densa, las onomatopeyas propician la kinestesia. Los elementos formales de las imágenes visuales se constituyen en un recurso para cargar emocionalmente los textos y se identifica sensibilidad al sufrimiento independiente de la función que cumplan los personajes en la historia.

Los sujetos inicialmente realizan la descripción pre-iconográfica al identificar los objetos y las situaciones que aparecen representadas, describen lo que perciben los sentidos de acuerdo con la experiencia. Después, hacen el análisis iconográfico en el que la imagen visual, partiendo de los aspectos denotativos y connotativos, se explica y se contextualiza dentro de una cultura determinada. Finalmente, efectúan la interpretación iconológica en la que se descubren significados implícitos en el texto en relación con el conjunto de ideas fundamentales que caracteriza su pensamiento como personas y colectividad (Steiner, 2012). En el tercer momento se relacionan las fuentes, se valoran los puntos de vista según evidencias, se les asigna relevancia a partes del texto respecto al todo, se detectan matices entre las líneas argumentales que reflejan propuestas ideológicas.

Los sujetos relacionan la información objetiva de las imágenes visuales con la conceptual. Identifican que los componentes de la imagen tributan al sentido de las 
claves lingüísticas, siendo evidente la estructura apodíctica de los textos. Las claves lingüísticas son una extensión de las imágenes visuales y viceversa. Los horizontes de expectativa, los marcos de conocimiento y de referencia ayudan a seleccionar los elementos y darles sentido. Así los sujetos vinculan la historia con experiencias personales que los lleva a cooperar con el texto. La información textual -sea claves lingüísticas o imágenes visuales- funciona como instrucción de procesamiento y los marcos de conocimiento remiten a la información adquirida que el sujeto puede activar para generar respuestas rápidas y apropiadas. Tales marcos ayudan a extraer significados, conferir coherencia a lo leído, determinar focos discursivos, generar niveles de representación, extraer información implícita de lo explícito, pronosticar ideas y activar procesos de recuperación. En otras palabras, el conocimiento poseído por los sujetos se erige como vínculo entre el texto y la realidad pragmática del mismo. Si los sujetos cuentan con el inicio y el clímax de los cuentos gráficos pueden predecir sin dificultad el final. Si se les proporcionan el clímax y el final se acercan un poco a suponer cuál es el inicio de la historia. Ahora bien, si disponen del inicio y el final se les obstaculiza conectar la información para intuir el posible dilema o la máxima tensión de la línea argumental. En los dos primeros casos los sujetos pueden acercarse a la versión original, pero adicionan conocimientos previos sobre la temática para reconstruir el sentido global basándose en sus expectativas como lectores. Los sujetos conectan sucesos de la historia, llenan los espacios vacíos o "lagunas" del texto y le adicionan sentidos provenientes de las conexiones con las circunstancias específicas del contexto y con los esquemas del lector. 
El diseño hipotáctico y apodíctico impide que se suprima cualquier parte de un cuento gráfico, no obstante, si falta información textual el sujeto se ve obligado a emplear la atención sostenida, la memoria de trabajo y la memoria episódica para cumplir con la tarea. La lectura se hace en espiral, las claves lingüísticas y las imágenes visuales se integran en la viñeta, que ofrece pictográficamente el mínimo de espacio y tiempo significativo; gracias al montaje elíptico se suprimen espacios y tiempos intermedios entre viñetas que permite la construcción de inferencias (Zabala, 2015). Sin olvidar que con mucha o poca información y con la ayuda de los esquemas se construye una estructura global que representa el texto, donde son cruciales los conocimientos que poseen de la estructura de los textos, los propósitos establecidos para la tarea de lectura y sus conocimientos previos del mundo.

Reflexionar y evaluar la información de un texto verbovisual implicaría no solo participar en prácticas sistemáticas de comprensión, integrar la interpretación de los códigos verbales e icónicos, si no el fortalecimiento de habilidades como la independencia de juicio, la reflexividad, la valoración de los datos y la flexibilidad de los esquemas.

\subsubsection{Integración de códigos}

Los textos narrativos están cercanos a la realidad discursiva de los sujetos porque se producen con mayor frecuencia y presentan menos dificultades en su comprensión. Estos textos se nutren del conocimiento lógico y común del mundo empírico, de ahí su familiaridad. El conocimiento previo con el que cuenta el lector permite que decida las acciones cognitivas que exige cada tipo de texto. Así, al 
enfrentarse a un texto narrativo se anticipa el marco organizativo de la historia a partir de la identificación y la evaluación de las secuencias de un argumento, los personajes, los motivos, las acciones, los conflictos, los estados emocionales, las resoluciones, las evaluaciones y los problemas de la vida diaria o de la ficción. El sujeto conoce la naturaleza típicamente episódica y es por eso que se interroga para saber qué sucedió (Trabasso y Magliano, 1996).

Lo anterior permite que el sujeto genere mayor número de inferencias en menor tiempo de lectura, dado que busca conexiones particulares entre hechos teniendo en cuenta la dimensión causal y temporal. Autores como Trabasso y Magliano (1995, 1996a, 1996b), Magliano (1999), Trabasso y Secco (1984), Van den Broek (1990, 1994), Graesser et al. (2002, 1997, 1996, 1994, 1992), Suh y Trabasso (1993), Langston y Trabasso (1998), De Vega (1996), Escudero (1999) han estudiado los textos narrativos y afirman que las relaciones causales son preponderantes porque el lector conecta hechos con consecuencias, aplicando estrategias de integración globales mientras construye el marco organizativo. Lo expuesto requiere que el lector produzca inferencias hacia adelante o predictiva y explicación retroactiva (León, 2003).

En el caso de los textos narrativos verbovisuales, la imagen visual y las claves lingüísticas afectan la comprensión, los sujetos se apoyan en la imagen visual para completar las lagunas informacionales, es decir, integran imagen visual y claves lingüísticas disponibles para comprender eficazmente los textos. Lo expresado ratifica la importancia de la información textual suficiente para la comprensión, dado que el individuo puede desestructurar la información y construir una estructura englobante significativa rellenada con inferencias. Pero si faltan elementos neurálgicos para el 
procesamiento (imagen visual o claves lingüísticas) los sujetos buscan en la información disponible para repetir, añadir, analizar, jerarquizar y relacionar datos que en su conjunto los lleve a una comprensión eficaz.

La apreciación y la conciencia de los lectores de los elementos visuales y las intenciones artísticas del texto permiten realizar el escrutinio de la imagen visual y el establecimiento de conexiones con la propia experiencia. La fundamentación sobre la imagen permite darles a los sujetos herramientas conceptuales que aumentan su grado de experticia en la lectura de imágenes.

La imagen visual amplia sintáctica y semánticamente las claves lingüísticas restringiendo la semiosis infinita y viceversa. Los sujetos tienden a priorizar las claves lingüísticas sobre las imágenes visuales, falta dar el salto a la integración de códigos, que es precisamente el objetivo de la intervención y que puede lograrse plenamente si se extiende el tiempo de la mediación.

Al inicio de la intervención los sujetos expresan que las imágenes visuales son más interesantes que las claves lingüísticas, pero al momento de leer priorizan las segundas sobre las primeras. Lo anterior propicia que identifiquen que las imágenes cuentan sus propias historias, el lector identifica dos tipos de códigos y cada uno cuenta una historia por separado. Se identifica que tanto los sujetos del grupo de estudio como del grupo control presentan las siguientes dificultades:

> Priorización en el reconocimiento y la interpretación de los códigos verbales

> Asunción de las imágenes visuales como ornamento de las claves lingüísticas.

$>$ Primacía de trayectorias rectilíneas de lectura 
> Preeminencia de la tendencia a la construcción global del texto sobre detalles cruciales para la estructura visual.

$>$ Desconocimiento parcial o total del análisis denotativo, connotativo y conceptual de la imagen visual.

D Desconexión entre información textual que permita la construcción de predicciones, anticipaciones, confirmaciones y autocorrecciones.

$>$ Priorización y justipreciación de la información secundaria sobre la primaria.

Al avanzar la intervención los sujetos se hacen más conscientes de la relación simétrica o de contrapunto entre las claves lingüísticas y las imágenes visuales. Tienen en cuenta el tamaño de los objetos y su disposición. Analizan las imágenes visuales identificando elementos que se relacionan con las claves lingüísticas, después buscan detalles. Al escudriñar la información prioritaria en las imágenes visuales se centran en los personajes y sus expresiones faciales, dejan de lado los espacios, prevalece la observación, la comparación, la supresión, la jerarquización y la generalización. Una de las principales dificultades es diferenciar la información prioritaria de la accesoria, se guían casi siempre por los aspectos formales de las imágenes visuales que en la reconstrucción de sentido local. Debido al impacto de la imagen visual y el apoyo de las claves lingüísticas, los sujetos impulsan sus capacidades atencionales y de percepción, que facilita el mantenimiento de la información local y global de los textos en la memoria de trabajo y, probablemente, en la memoria de largo plazo.

Al final de la intervención se logra que los sujetos lean las imágenes visuales con mayor detalle y las conecten con las claves lingüísticas, a la vez que valoran a los personajes como elementos cruciales de la línea argumental. Los lectores identifican 
que las claves paratextuales son detonadores para sugerir que el observador esté atento a otros significados posibles. Los procesos de deducción implican imaginación tanto como sentido.

La modificabilidad en la comprensión, promovida gracias al diseño de una experiencia de aprendizaje mediado, permite que los sujetos evidencien los avances compartidos a continuación.

Respecto al procesamiento de las claves lingüísticas:

$>$ Reconocer que la tipología a la que pertenezca un texto determina las partes que lo conforman y el orden de aparición de las mismas, la forma de leerlo y las expectativas del lector.

Dstablecer las relaciones sentenciales e intersentenciales que permiten sondear la coherencia y la cohesión.

Deconstruir la macroestructura o sentido del texto como un todo que exige la vinculación de las imágenes visuales con las claves lingüísticas.

Respecto al procesamiento de la imagen visual:

$>$ Establecer relaciones entre la significación y los elementos escalares (tamaño y espacio), morfológicos (punto, línea, color, luz, contraste, textura, forma) y dinámicos (composición, ritmo, encuadre, angulación, planos, profundidad y gutter).

$>$ Emplear creencias, conocimientos y estados anímicos para rastrear la intención del autor, significados sugeridos y su papel como receptor del discurso. 
D Estimar los elementos constitutivos de la imagen visual en razón de su función en el texto, nivel de representatividad y su anclaje en el contexto.

Respecto a la comprensión de textos verbovisuales:

Reconocer la relación figura - fondo y su impacto en la construcción del sentido.

D Descomponer la información en partes y establecer relaciones con el todo.

Integrar los conceptos aprendidos en la intervención en el análisis e interpretación de los textos verbovisuales.

> Vincular las claves lingüísticas con las imágenes visuales.

> Precisar las relaciones cuantitativas en imagen visual y claves lingüísticas.

$>$ Deducir las relaciones cualitativas en las imágenes visuales y claves lingüísticas.

\subsection{PROCESAMIENTO DE TEXTOS VERBOVISUALES, EL CASO DE LOS CUENTOS GRÁFICOS}

A partir de la recolección, el análisis y la interpretación de los datos y del modelo dual de memoria propuesto por Bruning et al. (2005), se construye un modelo del procesamiento de la información verbovisual que ratifica el rol de los procesos cognitivos (Figura 33). 


\section{Figura 33}

Modelo de procesamiento verbovisual

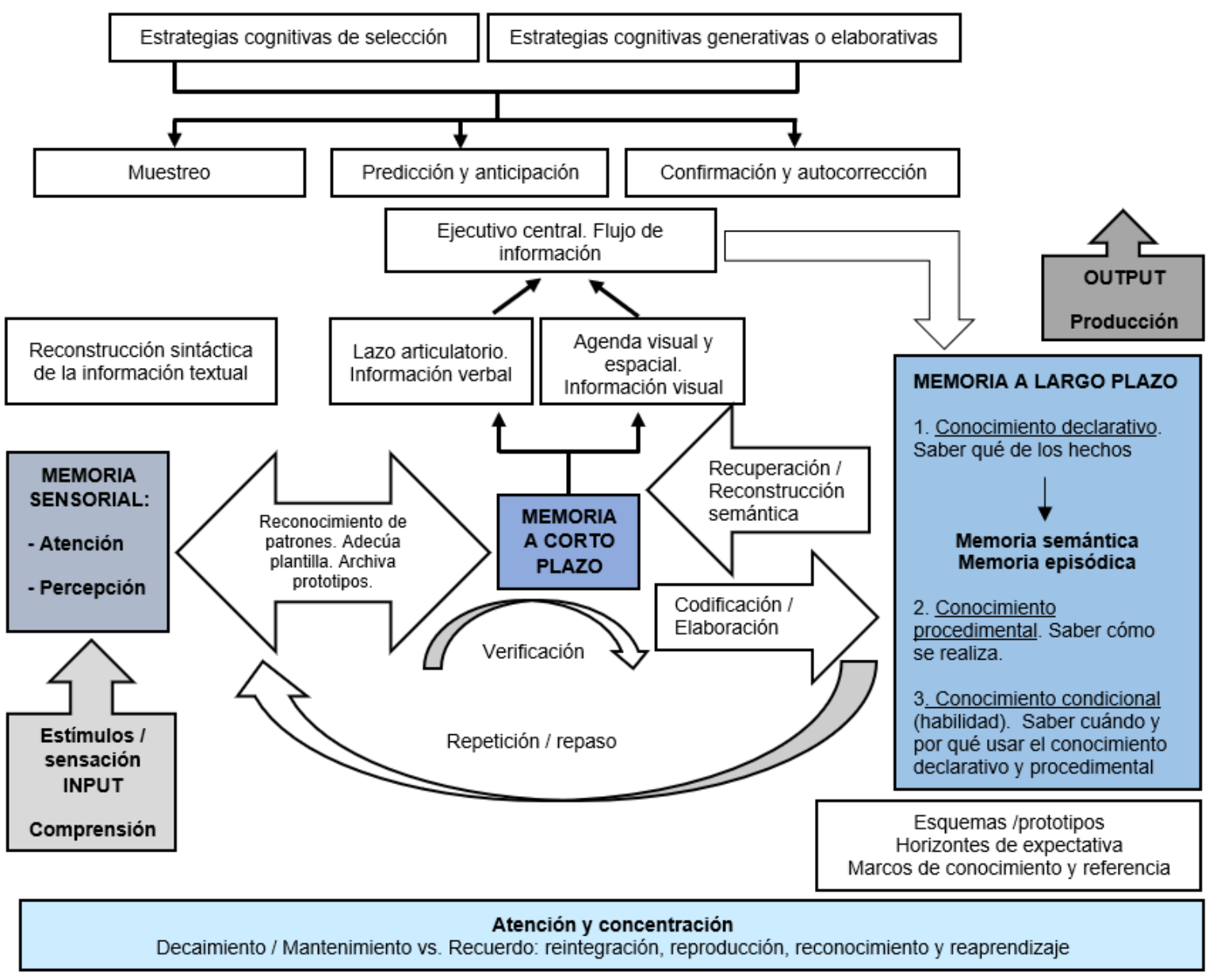

Fuente: Elaboración propia

La recepción de la información visual comienza en el ojo, éste tiene la facultad de percibir luz y con ella el contorno, las líneas, las texturas y las demás características físicas de la imagen. Esta información se conduce al lóbulo occipital que detecta los estímulos visuales. De manera casi automática la memoria sensorial selecciona los elementos que resultan significativos para caracterizar la imagen, luego de ser procesada por la memoria de trabajo y, finalmente, configurarse como una imagen mental en la memoria de a largo plazo. El ojo tiende a enfocar los objetos de mayor 
tamaño o lo que tenga interés para el lector, la observación se ve afectada por la expectativa de lectura porque da pautas sobre qué es lo que se debe buscar. Los sujetos continuamente se saltan detalles porque desean realizar la recuperación del sentido global sobre el sentido lineal. Primero identifican lo ordinario y lo esperado, después lo inesperado y extraordinario, se formulan preguntas, deducciones, hipótesis tentativas para luego confirmar o negar.

La tarea requerida determina las operaciones cognitivas que debe realizar el sujeto y el almacén de memoria que predomina en el procesamiento. Se recurre a la memoria a corto plazo para mantener activos significados relevantes que almacena en la memoria a largo plazo y podrá recuperarlos posteriormente; se mantiene la información mientras se realiza la tarea. El ejecutivo central regula el flujo de la información de la memoria a corto plazo a la memoria a largo plazo; el lazo articulatorio posibilita almacenar el material en un código verbal que facilita la recencia; y la agenda visual y espacial archiva el material codificado como imágenes visuales. Los procesos que se dan en la memoria dependen de las entradas y las salidas de la información que el cerebro considere relevante para así procesarla, codificarla y, si se pierde, recuperarla.

Para la codificación de los textos verbovisuales los sujetos inician la inspección de la imagen visual de la viñeta, después decodifica las claves lingüísticas, realizando la conversión de la escritura en mensaje fonético, posteriormente integran los mensajes fonéticos e icónicos para una comprensión global de la viñeta, recreando lo representado en función de la extensión de los diálogos y de la acción expuesta. Se reinicia el proceso con la siguiente viñeta hasta la terminación de la lectura del texto y 
la unión de cada una de las unidades de sentido recolectadas en cada viñeta y que se deben enlazar cual eslabones para la construcción global del texto, finalizar el proceso de comprensión y así sobrevivir a la relenti de la historia, es decir, la distorsión del flujo del tiempo real, para producir la impresión de que una acción dura más de lo que ocurriría en la realidad.

El procesamiento de la información implica la recepción de los estímulos externos, en el caso de la imagen visual el reconocimiento de las características formales que la constituyen, la composición visual, el nivel de iconicidad, la sinestesia de los personajes, la distribución espacial, etc. Generan en el sujeto la activación de operaciones cognitivas que permiten el reconocimiento de la estructura visual, es decir, en el plano denotativo de la imagen se lleva a cabo la reconstrucción sintáctica de la imagen visual fija, el lector reconoce el plano material de la misma, en consecuencia, la memoria sensorial y la memoria de trabajo constituyen en primera instancia los dos canales de percepción y procesamiento de la información visual.

La lectura que realizan es en espiral, inicia por lo verbal y pasa a lo visual, luego a la inversa, los cuentos gráficos favorecen dichas acciones gracias a su estructura iterativa basada en la recurrencia de un mismo modelo básico. En este contexto se determina que las imágenes visuales provocan inferencias prospectivas y las claves lingüísticas inferencias retrospectivas. Al respecto, Nikolajeva y Scott (2001) afirman que el lector inicia por el conjunto y después pasa a detalles, seguidamente regresa a la imagen completa para confrontar conclusiones, finalmente repite el proceso.

Ahora bien, si la información textual -sea claves lingüísticas o imágenes visuales-funciona como instrucción de procesamiento, los marcos de conocimiento y 
de referencia remiten a la información adquirida que el sujeto puede activar para generar respuestas rápidas y apropiadas. Tales marcos sirven para extraer significados, conferir coherencia a lo leído, determinar focos discursivos, generar niveles de representación, extraer información implícita de lo explícito, pronosticar ideas y activar procesos de recuperación. En otras palabras, el conocimiento poseído por los sujetos se erige como vínculo entre el texto y la realidad pragmática del mismo (Graesser et al., 1994; McKoon y Ratcliff, 1992, 1995; Schmalhofer et al., 2002; León, 2003).

Los sujetos se remiten a la información textual, al saber textual y a los marcos de conocimiento y de referencia. Al respecto De Vega (1990) afirma que:

Comprender el significado de un mensaje es una actividad extralingüística que supone activar representaciones conceptuales que incluye características sensoriales [forma y tamaño], motoras [movimientos requeridos], funcionalidad [utilidad], relaciones [otros conceptos], palabras que actúan como punteros que dispararían los correspondientes conceptos en la memoria semántica [red conceptual organizada paradigmática]. (p. 30)

Se relaciona la información textual (claves lingüísticas e imágenes visuales) con la información del mundo activada en la memoria a largo plazo. Lo anterior se explica porque "[..] el conocimiento previo influye directamente en la percepción, el reconocimiento de patrones y la asignación de significado, saber lo que vemos (u oímos) o a qué se parece (o suena) depende del conocimiento que ya se posee..." (Bruning at al., 2005, 28). 
El procesamiento del texto pasa por tres etapas conducentes a la comprensión. Inicialmente, se realiza la representación superficial de los cuentos gráficos; los sujetos perciben y decodifican la información textual, focalizan su atención en los datos que consideran importantes para la construcción de la estructura global, pueden o no archivarlos. Posteriormente, se forma el texto base; se parte de la información semántica para establecer las conexiones entre conceptos que constituyen el significado básico de los textos. Finalmente, se reforman los modelos de situación (De Vega y Díaz, 2003). Teniendo en cuenta los marcos de conocimiento y de referencia, se discrimina entre los indicadores contextuales y los conceptuales significativos para la interpretación, se activa la información archivada en la memoria a largo plazo que sea funcional según los propósitos de quien procesa y se ajuste a la plantilla y los prototipos. El resultado es una serie de nodos conceptuales variables que se almacena en la memoria a largo plazo para ser utilizados o activados en situaciones similares. No hay que olvidar que los modelos apropiados activan información adecuada y posibilita la comprensión eficaz.

El procesamiento puede darse de abajo-arriba y arriba -abajo. De abajo-arriba, está dirigido a la información y depende de la llegada de los datos de los receptores sensoriales, es decir, parte de los niveles inferiores como la decodificación de las claves lingüísticas y la percepción de la imagen visual, hasta llegar a los superiores como la elaboración de redes de significado. De arriba -abajo, ayuda a descubrir las combinaciones no adecuadas, está dirigido por las expectativas y los conceptos acerca de cómo está organizado el mundo. 
El procesamiento de claves lingüísticas e imágenes visuales se puede explicar bien sea desde la teoría dual o desde la teoría de codificación dual (Sierra,1995). La primera asegura que existen dos tipos de representación en dos sistemas diferentes, su divergencia está en el orden en el que se produce el acceso a la representación [visual, fonológica, semántica] (Nelson et al., 1977; Graesser y Bertus, 1998; Graesser y Bower, 1990; Graesser y Kreuz, 1993). La segunda sustenta que los sujetos ante dibujos o palabras deben acceder a distintos sistemas semánticos con distintas relaciones asociativas y semánticas (Bajo, 1999; Sierra et al., 2014; Ballesteros,1999) pero se presentan diferencias en el curso temporal de la activación de los mismos tipos de estímulos, alcanzando mayor impacto inmediato las imágenes visuales. Explicar el procesamiento verbovisual desde la codificación dual supone aceptar que dibujos y palabras se almacenan en distintos sistemas que difieren en el tipo de información con el que trabajan (visual versus verbal) y en las redes asociativas que conectan las unidades almacenadas en cada uno de ellos.

\subsection{ALFABETIZACIÓN PARA LA COMPRENSIÓN DE TEXTOS VERBOVISUALES NARRATIVOS}

La era digital ha permitido el posicionamiento de la imagen. La escuela debe brindarles a los estudiantes una experiencia mediante la cual puedan desarrollar y refinar los procesos cognitivos que faciliten la comprensión de textos en los que se empleen imágenes visuales (Arizpe y Styles, 2004). Los sujetos, aunque están embebidos en un contexto plagado de imágenes visuales, necesitan cambiar la idea de 
cómo deben interactuar con ese tipo de códigos y se les deben proporcionar las herramientas para hacerlo, alfabetizarlos verbovisualmente.

La alfabetización es el proceso que busca fortalecer y consolidar las habilidades y las destrezas adquiridas por el sujeto, se crean oportunidades de acceso y uso de conocimientos específicos. Exige un compromiso activo y autónomo, acentúa el rol del individuo no sólo en la generación y la recepción del mensaje sino también en la atribución de una interpretación independiente a cada mensaje. Es decir que con la alfabetización se afecta la construcción de conocimiento del mundo, el proceso cognitivo-creativo y la reelaboración del universo perceptivo simbólico, lógico e imaginativo; implica cambios en los sujetos y en las decisiones didácticas, ajustadas estás últimas a las necesidades, la habilidad de la lectura y la escritura, y que ese dominio permita cumplir con las exigencias comunicativas (Villa, 2008).

Toda imagen es signo que, a diferencia del signo verbal, se sofistica dentro de las reglas y las convenciones de la lengua escrita en la relación con otros signos. La imagen por sí misma suma sentidos y adquiere mayor complejidad, debe dar un salto cualitativo, pasar de signo puro a convertirse en representación (Anula Rebollo, 1998; Belinchón et al., 1992; De Vega y Cuetos, 1999). En este sentido, la alfabetización visual corresponde a una orquestación ingeniosa de ideas y actividades para fortalecer la habilidad de entender y usar imágenes para pensar y aprender en términos de imágenes, en otras palabras, pensar visualmente. Raney (citado por Arizpe y Styles: 2014, p. 76) afirma que alfabetizar visualmente es pensar sobre lo que significan las imágenes y los objetos, cómo se unen, cómo se responde a ellas o lo que se interpreta, cómo pueden funcionar a modo de pensamiento y cómo se ubican en las sociedades 
que las crearon. De tal forma que un plan de alfabetización no podría omitir la sensibilidad perceptiva, el conocimiento crítico que mediatiza la representación visual, la apertura, la elocuencia, el deleite estético, las prácticas culturales y los periodos históricos.

Las imágenes visuales son signos que pueden caracterizarse desde lo icónico y lo plástico. La primera, hace referencia a la similitud del signo con la realidad que representa y, la segunda, a los rasgos que distinguen un signo en particular de otro, es decir, los rasgos propios de cada signo. Los sujetos con la alfabetización visual incrementan su grado de experticia en la distinción en los textos verbovisuales de dichas características, identificando su estructura y sus funciones prototípicas según diferentes situaciones discursivas en las que se enmarcan los textos literarios multimodales.

La comprensión del texto verbovisual requiere de un entrenamiento previo. Si bien las imágenes operan, en muchos casos, como facilitadoras del procesamiento de la información de carácter verbal, también requieren de estrategias para su abordaje y la aplicación de actividades que potencien la comprensión de este tipo de textos. Por ello, se propone mediante el proceso de intervención basado en la alfabetización para la comprensión de textos verbovisuales, exponer a los participantes al procesamiento de cuentos gráficos para incrementar la cantidad de información textual disponible (conocimiento previo verbal y visual); proporcionar a los participantes mayores recursos para procesar la información y construir las inferencias necesarias para alcanzar la comprensión del texto; analizar lo que hacen a los participantes cuando comprenden 
textos verbovisuales narrativos; caracterizar el tipo de alfabetización necesaria para fortalecer la comprensión de este tipo de textos.

En la propuesta (figura 34) que se presenta las pruebas de comprensión, las actividades desestructurantes, el club de lectura, los ejercicios cognitivos y los juegos de estrategia favorecen la consolidación de procesos que preparan a los sujetos para rastrear las representaciones polisémicas en los cuentos gráficos, vinculándolos con los sentimientos y las creencias. Igualmente, la fundamentación teórica sobre imagen visual posibilita que identifiquen en el texto las características formales base para los análisis denotativos, connotativos y conceptuales, que a su vez se constituye en herramientas para sumergirse en procesos de comprensión integrales erigidos sobre la construcción de redes asociativas en la memoria a largo plazo y el refinamiento de los procesos perceptivos y atencionales. En definitiva, se producen cambios cognitivos estructurales.

\section{Figura 34}

Modelo de alfabetización verbovisual

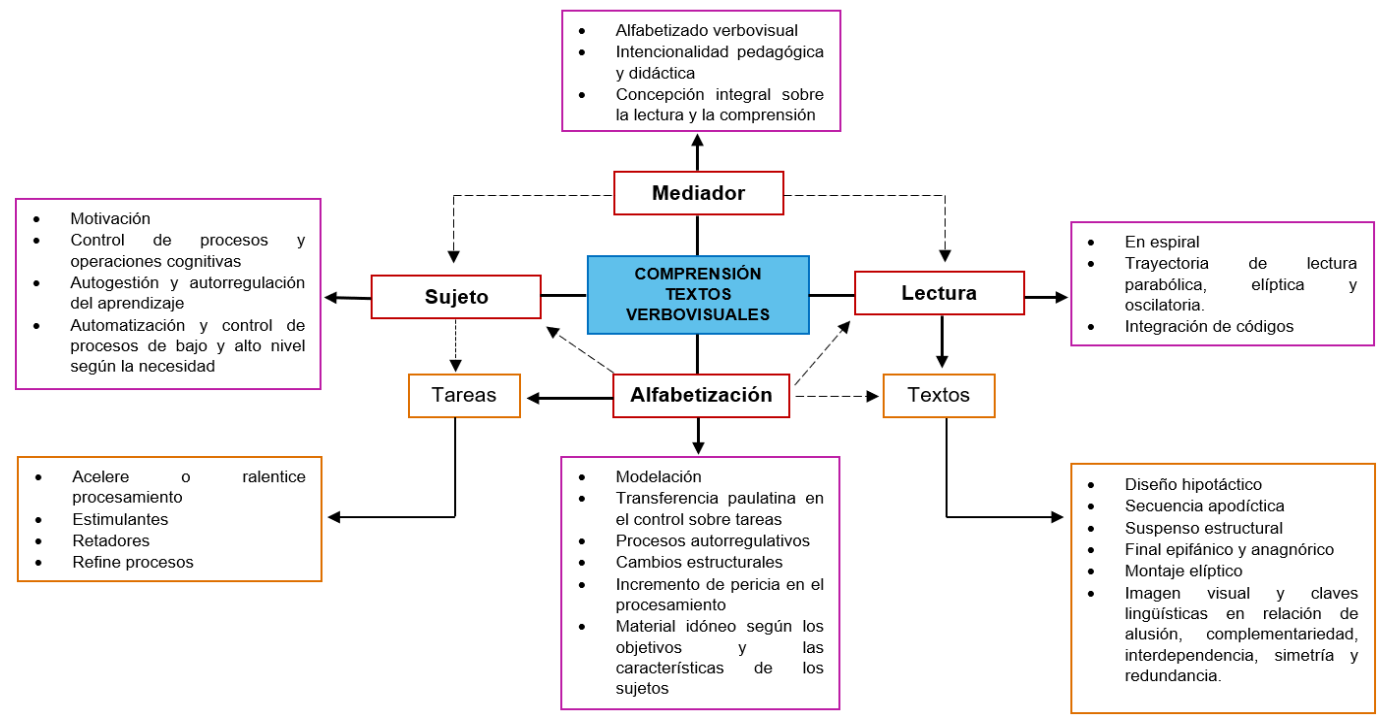

Fuente: Elaboración propia 
La alfabetización visual ayuda a hacer lecturas más integrales. Al inicio los sujetos solo tienen en cuenta el tamaño, el color, la luz, la intención del autor, el análisis macroestructural, únicamente realizan el muestreo y la predicción. Al finalizar, a parte de lo mencionado, empiezan a dar cuenta de los planos, las funciones y los objetivos de la imagen, el análisis microestructural y superestructural, formulan hipótesis que confirman y autocorrigen. Gracias al entrenamiento los sujetos pueden anticipar el patrón de contrapunto presente en los textos verbovisuales narrativos.

La selección de los textos y la planeación de cada una de las actividades de la intervención se centran en los sujetos, sus características de formación, su generación y los conocimientos previos. De tal forma que cada acción desarrollada por ellos es de su interés, tiene un impacto directo o indirecto sobre la comprensión. Los cuentos gráficos como piezas de arte alientan a observar lo conocido desde una perspectiva renovada, ayudan a mantener la atención y sostener una reflexión prolongada que se alimenta desde diferentes puntos de vista, promueven la superposición de los conocimientos personales y del mundo, suscitan la elaboración visual y el pensamiento analítico.

Se parte de la comprensión intuitiva de la imagen como herramienta para la identificación de ideas, emociones y relaciones en el texto. Pero la alfabetización mejora la profundidad de los razonamientos. El conocimiento previo se erige como contrafuerte en el momento de comprender, afecta cómo se perciben la relación claves lingüísticas e imágenes visuales. El acto de analizar textos verbovisuales requiere habilidades de lectura inferencial para vincular lo verbal con lo icónico. Se favorece la 
predicción, la resolución de problemas, la construcción conjunta de conocimiento y la tolerancia a la incertidumbre.

Por otra parte, el fortalecimiento del proceso de comprensión no sólo se limita a la recepción visual y a la decodificación de los mensajes, sino al nivel de instrucción recibido por el lector, se apoya la tesis planteada por Feuerstein (1990) que apunta a que todo individuo puede ser susceptible de ser modificado cognitivamente si se cuenta con un plan de intervención ajustado a sus necesidades y un "mediador" que realmente realice el seguimiento al proceso. De esta manera, si se lleva a cabo un proceso de instrucción que le proporcione pistas al sujeto sobre la adecuada lectura de las claves lingüísticas y las imágenes visuales, se gestaría una experiencia más completa del proceso de comprensión textual. No se desestima que la interpretación implica las diferencias individuales en la capacidad de la comprensión y puede fortalecerse por medio de un entrenamiento o intervención.

Es necesario que los cursos de instrucción en lectura de textos verbovisuales, se planteen en sus directrices el reconocimiento de las relaciones simétricas entre las claves lingüísticas y la imagen visual, y su aporte al reconocimiento de las estructuras textuales y a la elaboración de inferencias. Por consiguiente, en una intervención que busque la alfabetización visual se debe tener claro el nivel de instrucción, los objetivos de cada actividad, el papel del mediador y la calidad del material de los textos.

Entonces, se propone que ante la necesidad de capacitar al lector para que se enfrente a textos verbovisuales como los cuentos gráficos, es imprescindible crear las condiciones para un cambio estructural, es decir, permanente, que se expanda de tal forma que afecte todo el procesamiento y se centralice gracias a la autonomía y la 
autorregulación. Para ello, la experiencia de aprendizaje debe ser mediada por un agente que exponga a los sujetos directamente a estímulos. En la mediación es esencial la intencionalidad por parte del experto en la planeación y la ejecución de cada una de las acciones, la selección de los cuentos gráficos, los ejercicios cognitivos y los juegos de estrategia.

La reciprocidad por parte de los sujetos en la participación y la receptividad en cada una de las actividades propuestas es trascendental; su disposición al cambio, el sentirse capaz de hacer la tarea, la estimulación a la responsabilidad del propio aprendizaje, el desarrollo autónomo y el reconocimiento de diferencias individuales, la promoción de la necesidad de relacionarse con otros para monitorear sus procesos de análisis, enlazar estímulos y enfrentarse a situaciones nuevas de aprendizajes que desafíen a los sujetos y los obliguen a buscar estrategias. Lo expresado permite la motivación intrínseca que asegura el éxito de la intervención. Aprender y enseñar como parte del proceso.

La lectura desde el punto de vista cognitivo implica reconocer la centralidad de los procesos de bajo nivel y alto nivel. Los primeros tienen la función de decodificar el texto, su manejo puede ser más o menos automático, son indispensables para iniciar la comprensión, se transforma el código escrito en unidades con significado. En los segundos se construyen inferencias, se emplea la función ejecutiva y la atención, en otras palabras, se vincula el texto con el conocimiento previo, se organiza y se reflexiona sobre la información, se supervisa la comprensión. Los procesos de bajo nivel pueden ejecutarse a pesar de la falta de éxito de los procesos de alto nivel, pero los segundos no pueden realizarse correctamente si los de bajo nivel han sido 
ejecutados en forma deficiente. Entonces, a mayor automatización de los procesos de bajo nivel, mayores posibilidades de lograr la comprensión profunda de un texto, ya que los recursos atencionales pueden concentrarse en la ejecución de los procesos de alto nivel. Lo expresado ha ocasionado que los docentes prioricen los procesos de bajo nivel sobre los de alto nivel, instrumentalizando la lectura. Una alfabetización efectiva en comprensión debe abordar los dos niveles en igualdad de condiciones, potencializando tanto el uso de la percepción, la atención y la memoria en el procesamiento tanto de claves lingüísticas como de imágenes visuales. En la alfabetización se exponen a los sujetos a situaciones retadoras para incrementar el banco de experiencias visuales. Los ejercicios cognitivos y los juegos se seleccionan especialmente para alentarlos a profundizar y fortalecer la habilidad de procesar lo visual.

En los contextos de instrucción se limita la compresión a la interpretación de textos de diferentes géneros, es un producto más que un proceso. En las escuelas los docentes les enseñan a los estudiantes a decodificar, usar técnicas de lectura y responder pruebas. No obstante, trabajar la comprensión debe partir del fortalecimiento de procesos cognitivos, por eso se asume como un proceso integral que va más allá de aplicar pruebas, y que deben llevarse a cabo tareas que reten a los sujetos a consolidar procesos.

Los datos recolectados en la investigación revelan la necesidad de adelantar procesos de alfabetización verbovisual no solo con estudiantes si no con docentes. Es imprescindible el entrenamiento de los últimos, establecer una ruta de trabajo y crear material idóneo que permita a todos los actores del proceso educativo superar la 
tradición logocéntrica y transitar a la concepción de la comprensión como un proceso integral enfocada al procesamiento de textos de diversas modalidades. Es decir, se debe transitar de la asunción de la comprensión como una actividad lingüística, instrumental, una evidencia de conocimiento; a la comprensión como proceso, fin en sí misma, centrada en el sujeto que se autoconfigura. Una alfabetización efectiva en comprensión debe abordar procesos de bajo y alto nivel en igualdad de condiciones, potencializando la sensación, la percepción, la atención, la concentración y la memoria en el procesamiento de claves lingüísticas como de imágenes visuales.

\subsection{RECAPITULACIÓN}

Los grupos control y estudio en el momento de la pre prueba evidenciaban desempeños relativamente iguales en la comprensión de textos verbovisuales narrativos. Posterior a la intervención se identifican en el grupo de estudio diferencias significativas que dan cuenta de un incremento en sus habilidades y procesos reflejados en sus inputs. Lo expresado se ratifica en el análisis cuantitativo compartido en el capítulo 4.

Los datos analizados cualitativamente corresponden a la información recolectada de las actividades desestructurantes y el club de lectura. En términos generales se aprecia que 9 de 10 sujetos del grupo de estudio se les facilita realizar el muestreo de los textos; al principio de la intervención manifiestan duda y el tiempo invertido para la finalización de las tareas es alto. Una vez familiarizados con los procedimientos exigidos por los textos verbovisuales narrativos se les hace más fácil cumplir con éxito las diferentes demandas. La producción de inferencias les causa 
dificultad, aunque avanzan en la integración de códigos no alcanzan el nivel óptimo, les cuesta la interpretación del diseño hipotáctico de este tipo de textos. $3(1,3$ y 6$)$ de los 10 sujetos del grupo de estudio muestran un desempeño constante en la construcción de predicciones, anticipaciones, confirmaciones y autocorrecciones; 5 sujetos $(2,4,9$, $8,10)$ predicen y realizan anticipaciones pero no confirman hipótesis o se autocorrigen; 2 sujetos ( 5 y 7 ) realizan predicciones sin integrar códigos, o bien priorizan las claves lingüísticas o bien las imágenes visuales. La reflexión y la evaluación es el subproceso más complejo porque al principio la mayoría de los sujetos se limitan a justipreciar la información basándose en su opinión, al final pueden contrastar la información textual y su conocimiento previo en función de comprensión.

La modificabilidad en la comprensión se logra gracias al trabajo controlado e intencionado con la información disponible en los textos verbovisuales narrativos. Los sujetos avanzan en el refinamiento de la recuperación de información, la producción de inferencias, la reflexión y la evaluación de la información a consecuencia de la intervención que implica la disposición al cambio por parte de los sujetos, el entrenamiento, el seguimiento de la conducta verbal, la exposición directa a los estímulos y la reconfiguración conceptual adecuada.

Se reconoce que la información superficial es irrelevante y efímera en términos de mantenimiento, su función es propiciar la activación desencadenada de información, por ello, es considerada de nivel bajo, se constituye en el camino para llegar a la comprensión de los textos. Por su parte, la Información profunda es crucial y permanente en la memoria, es producto de la actividad inducida o autoinducida, de la capacidad que tenga el sujeto para manejarla depende la eficiencia en el 
procesamiento. Además, el grado de pericia de los sujetos y el grado de exposición a textos verbovisuales narrativos favorece la selección u omisión de información textual y enciclopédica. La última, es necesaria para crear conexiones y limitar la proyección de las representaciones; la primera, es crucial en la medida que se erige como el soporte físico de toda interpretación. En este sentido, la textualidad posibilita la activación de conocimientos agregados, incrementa el número de inferencias y determina la comprensión.

Los cuentos gráficos se procesan de forma dual (Nelson et al., 1977, Glasser, 1992). Se realizan dos tipos de representación en dos sistemas diferentes, su divergencia está en el orden en el que se produce el acceso a la representación (visual, fonológica, semántica). De esta forma, en el procesamiento de dibujos se accede a la representación semántica para poder nombrar, su activación fonológica es más lenta; pero en las claves lingüísticas se accede a la representación fonológica y después, optativamente, a la representación semántica. Entonces, los sujetos ante claves lingüísticas o imágenes visuales acceden a distintos sistemas semánticos con distintas relaciones asociativas y semánticas, pero se presentan diferencias en el curso temporal de la activación de los mismos tipos de estímulos, alcanzando las imágenes visuales mayor impacto inmediato y superioridad mnésica. Así, los procesos cognitivos cimientan el procesamiento y vehiculizan el uso las estrategias cognitivas de selección y generativas.

Comprender textos verbales exige el procesamiento escalonado y complejo pero el sujeto solo debe transformar un solo tipo de código, que permite la focalización en acciones y desempeños con alta probabilidad de éxito. No obstante, comprender textos 
verbovisuales demanda la concordia entre las claves lingüísticas y las imágenes visuales, los sujetos deben activar múltiples informaciones y engranar códigos de diferente naturaleza. En consecuencia, la comprensión de la que se reflexiona en estas páginas no puede seguir minimizándose y restringiendo a procesos logocéntricos, se debe ayudar al sujeto a pensar visualmente, a ofrecer tareas que lo acerquen al código y también lo entrenen para ser más efectivo.

En síntesis, gracias al análisis cuantitativo y cualitativo se puede afirmar que la información de carácter visual resulta subsidiaria del procesamiento de la información verbal y requiere, al igual que esta última, de estrategias para su análisis. El desarrollo de estrategias específicas en el sujeto lector favorece la comprensión del texto verbovisual.

Lo expresado nos lleva a concluir que:

1. Las claves lingüísticas y las imágenes visuales son partes inseparables de un todo que da paso a procesos de comprensión integrales, complejos y flexibles propios de los textos verbovisuales narrativos.

2. Si se intensifica la exposición del sujeto a textos verbovisuales narrativos y participa en la aplicación de estrategias para su procesamiento, se facilitan los procesos de recuperación de conocimiento previo y su uso para la asimilación de estímulos nuevos. A mayor tiempo, frecuencia e intensidad de intervención mayor efecto en el fortalecimiento de los procesos de comprensión de textos verbovisuales.

3. Los procesos de intervención para la comprensión en su gran mayoría priorizan los códigos verbales, ratificándose la tradición logocentrista y disminuyendo la 
variabilidad en el procesamiento textual que afecta la habilidad para realizar muestreo, producir inferencias, reflexionar y valorar la información. Adelantar procesos de alfabetización verbovisual proporciona beneficios derivados de la experiencia mediada que se manifiestan en el comportamiento adaptativo de los sujetos y el aumento en el grado de experticia en la comprensión. 


\section{CAPÍTULO 6}

\section{CONCLUSIONES GENERALES}




\subsection{PALABRAS FINALES}

En la investigación se explica, desde los planteamientos de la psicolingüística, la incidencia de las claves lingüísticas y la imagen visual en la comprensión de textos narrativos verbovisuales como el cuento gráfico. Para ello, se describe el proceso realizado por los sujetos de estudio cuando comprenden textos narrativos verbovisuales, se compara y se analiza la relación de las claves lingüísticas y la imagen visual en la comprensión de textos narrativos verbovisuales.

Para alcanzar lo descrito en el anterior párrafo, se diseña una intervención conformada por una prueba pretest y post test aplicada al grupo control y al grupo estudio, tres pruebas de monitoreo suministradas al grupo estudio; el objetivo es realizar el seguimiento del proceso, los resultados se someten a análisis estadísticos para dar cuenta del desempeño de los sujetos. Adicionalmente, en el transcurso de 14 sesiones de trabajo, los sujetos del grupo de estudio resuelven ejercicios cognitivos, actividades desestructurantes, participan de juegos de estrategia y reciben alfabetización visual; el fin de ello es levantar información que se analiza cualitativamente para así dar cuenta del proceso de comprensión de textos verbovisuales narrativos y la necesidad de desarrollar una alfabetización visual que proporcione a los sujetos herramientas que le permitan realizar lecturas más profundas y efectivas de los textos en mención.

El análisis cuantitativo permite apreciar las diferencias entre los grupos. Teniendo en cuenta los puntajes alcanzados en las medidas repetitivas y representado en curvas de aprendizaje, del momento pre test al post test 3 sujetos del grupo control muestran progresos en su comprensión, 3 permanecen igual y 4 disminuyen sus 
aciertos. Tal resultado es independiente a la investigación y sus razones son aleatorias puesto que los sujetos no son objeto de seguimiento. Por su parte, en el grupo estudio 7 sujetos $(1,2,3,6,8,9,10)$ acrecientan su rendimiento, 1 (4) demuestra adelantos hasta a mitad de la intervención y luego se ralentiza, 2 (5 y 7 ) avanzan mínimamente. Lo expresado se corrobora con el análisis de Clúster, en el momento pre test los conglomerados son indeterminados, es decir, se agrupan independiente a la pertenencia o no a un grupo. En el momento post test 7 de los 10 sujetos del grupo de estudio se aglutinan al lado derecho de la figura 32 (p. 167), lo que demuestra avances en la modificabilidad de su comprensión. Finalmente, el análisis multivariado da cuenta de cada uno de los momentos de la intervención, mostrando que los procesos de los sujetos experimentan incrementos y decrementos mínimos, comportamiento típico en el aprendizaje medido, la diferencia radica en las decisiones y ajustes a partir de los hallazgos.

Los datos analizados cualitativamente corresponden a la información recolectada de las actividades desestructurantes y el club de lectura. En términos generales se aprecia que 9 de 10 sujetos del grupo de estudio se les facilita realizar el muestreo de los textos; al principio de la intervención manifiestan duda y el tiempo invertido para la finalización de las tareas es alto. Una vez familiarizados con los procedimientos exigidos por los textos verbovisuales narrativos se les hace más fácil cumplir con éxito las diferentes demandas. La producción de inferencias les causa dificultad, aunque avanzan en la integración de códigos no alcanzan el nivel óptimo, les cuesta la interpretación del diseño hipotáctico de este tipo de textos. $3(1,3$ y 6$)$ de los 10 sujetos del grupo de estudio muestran un desempeño constante en la construcción 
de predicciones, anticipaciones, confirmaciones y autocorrecciones; 5 sujetos $(2,4,9$, $8,10)$ predicen y realizan anticipaciones pero no confirman hipótesis o se autocorrigen; 2 sujetos ( 5 y 7 ) realizan predicciones sin integrar códigos, o bien priorizan las claves lingüísticas o bien las imágenes visuales. La reflexión y la evaluación es el subproceso más complejo porque al principio la mayoría de los sujetos se limitan a estimar la información basándose en su opinión, al final pueden contrastar la información textual y su conocimiento previo en función de comprensión.

Con el objetivo de describir el proceso realizado por los sujetos de estudio cuando comprenden textos verbovisuales narrativos se realiza el seguimiento de su comportamiento verbal a partir de la información levantada de las actividades desestructurantes y el club de lectura. En este orden se identifica que:

La percepción es provocada por la excitación espontánea del sistema nervioso central y demanda un proceso instruccional para optimizar el procesamiento textual. La dirección visual ayuda a entender la forma cómo se seleccionan y discriminan los estímulos conforme al tiempo, el espacio y los objetos. Dependen directamente de la composición de la imagen y la distribución de los elementos, apoya al proceso de percepción y a la memoria sensorial (Belinchón et al., 1992). Los sujetos realizan acciones de fijación y saltos en elementos específicos. Lo expresado posibilita la superposición de trayectorias rectilíneas propias de los textos monomodales y de trayectorias curvilíneas inherentes a los textos multimodales que exigen movimientos de lectura parabólicos, elípticos y oscilatorios en la superficie bidimensional del texto. 
Los sujetos en la ruta de dirección visual usan los códigos pictóricos de forma diferente (Tapia, 2005). Los códigos perceptivos, espaciales, gestuales, y simbólicos presentan mayores facilidades para los sujetos; los códigos cromáticos deben ser aprovechados con mayor insistencia, no limitarlos a simples ornamentos; los códigos morfosintácticos y retóricos muestran avances constantes dado el grado de tecnicidad que implican.

En el procesamiento de la imagen visual los analizadores objetivos ayudan a decodificar la imagen con procesos de abajo-arriba (Anula Rebollo, 1998; De Vega y Cuetos, 1999). Los sujetos proyectan y analizan el campo visual de forma simultánea y automáticamente. Con la memoria sensorial se capta un conjunto de datos que son expuestos a procesos como la jerarquización, la generalización y la asociación, que ayudan a eliminar los elementos innecesarios. La información trascendental pasa a la memoria de trabajo, en la cual se le asigna significado dependiendo de la tarea propuesta y de los propósitos interpretativos del sujeto. Así se van creando hipótesis parciales. Finalmente, la información etiquetada como importante es archivada provisionalmente en la memoria de trabajo o en la memoria a largo plazo, para así permanecer activada unos segundos más o estar disponible para usarse en posteriores procesamientos.

$>$ El procesamiento de la información varía según las modalidades y la relación entre ellas (Ballesteros,1999). Se presentan diferencias entre el procesamiento de información pictórica e información verbal puesto que corresponden a diferentes sistemas o representaciones. Los estímulos pictóricos son más 
rápidos, sus representaciones son regulares, se establecen con celeridad redes asociativas entre el estímulo visual y los datos almacenados en la memoria a largo plazo permitiendo su mantenimiento y estructuración, lo que reduce la recencia y ratifica la eficacia. Entonces podría afirmarse que, a pesar de las ventajas procesales de la información pictórica, dibujos y palabras acceden al mismo tipo de representación semántica, dependiendo del orden de acceso, la facilitación y las exigencias de la tarea.

En este sentido se prueba que las claves lingüísticas y las imágenes visuales son partes inseparables de un todo que da paso a procesos de comprensión integrales, complejos y flexibles propios de los textos verbovisuales narrativos.

Para comparar el procesamiento de las claves lingüísticas y la imagen visual en la comprensión de textos verbovisuales narrativos se proponen actividades de análisis de cuentos gráficos que exigían el procesamiento de los códigos pictóricos y verbales ya sea por separado o vinculados en función del proceso de interpretación. Se concluyo que:

$>$ El procesamiento de la información de la imagen visual implica reconocer las características formales que la constituyen, la composición visual, el nivel de iconicidad, la sinestesia de los personajes, la distribución espacial, etc., que generan en el sujeto la activación de procesos cognitivos como percepción, atención, memoria sensorial y memoria de trabajo, que permiten el reconocimiento de la estructura visual, sus aspectos denotativos y sintácticos (Anula, 1998; De Vega y Cuetos, 1999). Adicionalmente, en la lectura desde lo connotativo se acuden a las experiencias de tipo cultural y social de las que ha 
participado el sujeto, dando lugar a interpretaciones subjetivas frente a la imagen.

Los sujetos relacionan la información objetiva de las imágenes visuales con la conceptual. Identifican que los componentes de la imagen tributan al sentido de las claves lingüísticas, siendo evidente la estructura apodíctica de los textos. Las claves lingüísticas son una extensión de las imágenes visuales y viceversa. Los horizontes de expectativa, los marcos de conocimiento y de referencia ayudan a seleccionar los elementos y darles sentido. Así los sujetos vinculan la historia con experiencias personales que los lleva a cooperar con el texto. La información textual -sea claves lingüísticas o imágenes visuales- funciona como instrucción de procesamiento y los marcos de conocimiento remiten a la información adquirida que el sujeto puede activar para generar respuestas rápidas y apropiadas. Tales marcos ayudan a extraer significados, conferir coherencia a lo leído, determinar focos discursivos, generar niveles de representación, extraer información implícita de lo explícito, pronosticar ideas y activar procesos de recuperación. En otras palabras, el conocimiento poseído por los sujetos se erige como vínculo entre el texto y la realidad pragmática del mismo.

Las claves lingüísticas y las imágenes visuales son expuestas a un análisis relacional de sentido. Al final de la intervención, la mayoría de los sujetos procesan inicialmente las imágenes visuales optando por un examen paradigmático de las mismas; seguidamente, focalizan su atención en las claves lingüísticas, pero realizan saltos visuales que requieren de análisis sintagmáticos 
y paradigmáticos de forma simultánea. La imagen visual por sí misma activa un cúmulo de información que contextualiza al cuento gráfico, reduce las operaciones cognitivas de asociación porque se hacen más explicativas. La imagen visual amplia sintáctica y semánticamente las claves lingüísticas restringiendo la semiosis infinita y viceversa. Los sujetos tienden a priorizar las claves lingüísticas sobre las imágenes visuales, falta dar el salto a la integración de códigos, que es precisamente el objetivo de la intervención y que puede lograrse plenamente si se extiende la mediación.

$>$ La imagen visual y las claves lingüísticas afectan la comprensión, los sujetos se apoyan de la imagen visual para completar las lagunas informacionales, es decir, integran imagen visual y claves lingüísticas disponibles para comprender eficazmente los textos. Lo expresado ratifica la importancia de la información textual suficiente para la comprensión, dado que el individuo puede desestructurar la información y construir una estructura englobante significativa rellenada con inferencias. Pero si faltan elementos claves para el procesamiento (imagen visual y claves lingüísticas) los sujetos buscan en la información disponible para repetir, añadir, analizar, jerarquizar y relacionar datos que en su conjunto los lleve a una comprensión eficaz.

Los sujetos inicialmente realizan la descripción pre-iconográfica al identificar los objetos y las situaciones que aparecen representadas, describen lo que perciben los sentidos de acuerdo con la experiencia. Después, hacen el análisis iconográfico en el que la imagen visual, partiendo de los aspectos denotativos y connotativos, se explica y se contextualiza dentro de una cultura determinada. 
Finalmente, efectúan la interpretación iconológica en la que se descubren significados implícitos en el texto en relación con el conjunto de ideas fundamentales que caracteriza su pensamiento como personas y colectividad (Steiner, 2012).

Los sujetos realizan estrategias cognitivas como el reconocimiento perceptivo de las formas visuales -letras o palabras-; la selección de la información productiva y útil del procesador léxico, sintáctico y semántico; la construcción de inferencias a partir de las información disponible (claves lingüísticas e imágenes visuales); la predicción, la confirmación y la corrección de líneas de lectura partiendo esencialmente de integrar información del texto mismo y de sus marcos, y la generalización de la información surgiendo una reconstrucción comprensiva del texto. Construyen inferencias ligadas al texto partiendo de la integración de información, generalizan cuando abstraen de lo que es común y esencial a los textos para formar un concepto general que da cuenta de la comprensión. Los anteriores procesos varían según la calidad de expertos o novatos de los sujetos y el conocimiento previo conforma redes de conceptos.

En los textos verbovisuales se recurre al procesamiento dual (Sierra et al., 1995). Se produce el acceso a la representación visual fonológica y semántica de las claves lingüísticas y se accede a la representación semántica de las imágenes visuales para verbalizarlas. Entonces, los sujetos ante dibujos o palabras acceden a distintos sistemas semánticos con distintas relaciones asociativas, pero se presentan diferencias en el curso temporal de la activación de los mismos tipos de estímulos, alcanzando las imágenes visuales mayor 
impacto inmediato y superioridad mnésica. Según el modelo dual de memoria, la información no necesariamente debe pasar por un módulo a la vez, puesto que la información que recibe la memoria a largo plazo puede analizarse, reajustarse y establecer conexiones de forma alterna en la memoria a corto plazo y la memoria a largo plazo, consiguiendo resultados parciales y totales. El proceso descrito permite la construcción de inferencias durante y después del procesamiento, y en su totalidad facilita la comprensión. Los materiales concretos se recuerdan mejor que los abstractos porque se codifican en la memoria a largo plazo tanto en un código de imágenes como en un código verbal. Esta dualidad de codificación favorece que el procesamiento sea más elaborado y distintivo.

Entonces, si se intensifica la exposición del sujeto a textos verbovisuales narrativos y participa en la aplicación de estrategias para su procesamiento, se facilitan los procesos de recuperación de conocimiento previo y su uso para la asimilación de estímulos nuevos. A mayor tiempo, frecuencia e intensidad de intervención mayor efecto en el fortalecimiento de los procesos de comprensión de textos verbovisuales. Luego de describir el proceso realizado por los sujetos de estudio cuando comprenden textos verbovisuales narrativos, y comparar el procesamiento de las claves lingüísticas y la imagen visual, se puede analizar la relación entre ellas. Los puntos centrales se comparten a continuación:

$>$ Los textos narrativos están cercanos a la realidad discursiva de los sujetos porque se producen con mayor frecuencia y presentan menos dificultades en su comprensión. Se conoce la naturaleza típicamente episódica y estimula a 
preguntarse por el qué sucedió (Trabasso y Magliano, 1996). Permite que el sujeto genere mayor número de operaciones cognitivas en menor tiempo de lectura, dado que busca conexiones particulares entre hechos teniendo en cuenta la dimensión causal y temporal.

Los cuentos gráficos empleados se caracterizan por aprovechar recursos como el suspenso estructural, el final epifánico y la anagnórisis. Los elementos formales de las imágenes visuales, complementadas con las claves lingüísticas, se constituyen en un recurso para cargar emocionalmente el texto y se establecen vinculaciones afectivas independiente de la función que cumplan los personajes en la historia.

D Los textos verbovisuales provocan incertidumbre en el receptor, induciéndolo a intentar averiguar lo que no sabe, de modo que deduce consecuencias que le llevan a un resultado, es decir, recupera información a través del muestreo, produce inferencias al predecir y anticipar, reflexiona y evalúa la información por medio la confirmación y autocorrección de hipótesis. Además, los cuentos gráficos están pensados para que la incertidumbre despierte el interés del público, pero son lo suficientemente sencillos para que sean comprendidos gracias a un proceso de cooperación texto-lector-contexto.

En su procesamiento las inferencias ocurren cuando se establecen conexiones entre las claves lingüísticas y las imágenes visuales, se organizan redes conceptuales, se busca fuera del texto informaciones y conocimientos con los cuales se rellenan los huecos textuales. Los sujetos pueden producir a partir de la información verbovisual un número considerable de inferencias gracias a la 
intervención de la memoria sensorial y de trabajo, y el ajuste entre información textual e información previa, pero si no establece redes conceptuales entre lo anterior no se llegará a la comprensión efectiva del texto. Los sujetos emplean estrategias cognitivas inferenciales selectivas cuando realizan la lectura rápida para identificar el significado de las claves lingüísticas y la imagen visual cuyo fin es cumplir con la tarea, captan de forma acumulativa los datos relevantes. Igualmente, usa estrategias cognitivas generativas cuando elaboran esquemas integradores de la información, resumen, parafrasean, subrayan, discriminan, jerarquizan, comparan-contrastan, proyectan, recuperan, evocan, predicen (McKoon y Ratcliff, 1992).

$>$ El ensamble verbo - icónico del contenido de textos verbovisuales narrativos determina los distintos procesos cognitivos que el sujeto debe activar para llevar a cabo su comprensión. La superestructura del cuento gráfico responde al género literario, por tanto, prevalecen herramientas discursivas que configuran la secuencia de hechos ocurridos en un determinado espacio y tiempo, anclado al lenguaje icónico y a su carga simbólica, adquiriendo complejidad. Para decodificar el mensaje se considera que la información lingüística traduce las escenas, es decir, la palabra devela el significado de la imagen, creando un nivel de compatibilidad donde el texto aporta el aspecto conceptual y la imagen la información sensorial. En la medida en que el sujeto reconozca las características y la funcionalidad de ambos códigos será certero al momento de reconstruir la diégesis del texto, al conectar la información de entrada con los esquemas previos, agilizando así la producción de inferencias. 
$>$ El diseño hipotáctico y apodíctico impide que se suprima cualquier parte de un cuento gráfico inferencias (Zabala, 2015). La lectura se hace en espiral, las claves lingüísticas y las imágenes visuales se integran en la viñeta, que ofrece pictográficamente el mínimo de espacio y tiempo significativo; gracias al montaje elíptico se suprimen espacios y tiempos intermedios entre viñetas que permite la construcción de inferencias. Sin olvidar que con mucha o poca información y con la ayuda de los esquemas se construye una estructura global que representa el texto. En otras palabras, cuán elaborado sea el mensaje dependerá de la capacidad de los sujetos para realizar inferencias, de sus conocimientos previos, de los propósitos establecidos para la tarea de lectura y el conocimiento que poseen de la estructura de los textos.

Los sujetos evidencian regularmente dificultades para identificar el suspenso estructural, el final epifánico, la anagnórisis, los personajes y los espacios que determinan la función dramática, se preocupan por asir los elementos que les facilita la construcción idea global del texto, dejando de lado los elementos microestructurales y sus conexiones (Zabala, 2015). Tienen problemas para realizar multitareas: leer, buscar elementos de forma consciente, subrayar según convenciones, comparar datos, verificar hipótesis.

La tarea requerida determina las operaciones cognitivas que debe realizar el sujeto y el almacén de memoria que predomina en el procesamiento. La realización de tareas que canalizan la visión de los sujetos fortalece la memoria visual, vincula la búsqueda visual con la verbal. Adicionalmente, los sujetos ejercitan el razonamiento hipotético y transitivo. El primero al abstraer los 
sentidos del texto, al anticiparse a los posibles resultados en la acción narrativa; el segundo al utilizar la información explícita para poder sacar conclusiones, codificar, representar y revertir (Cedillo, 2010).

$>$ Una de las formas de movilizar los procesos necesarios para el procesamiento de textos verbovisuales narrativos es solicitar a los sujetos que lean teniendo claro un fin; no caer en el interés solo por la idea global del texto o los detalles, equilibrar acciones; enlazar los horizontes de expectativas a las líneas argumentativas de los cuentos gráficos y conocimientos previos; emplear los aspectos abordados sobre el análisis de la imagen visual y las claves lingüísticas.

$>$ Formularse preguntas sobre lo que se hace mientras se lee es esencial, no solo para recoger información sobre cómo se procesan textos verbovisuales, sino para que los sujetos se percaten de las acciones cognitivas puestas en marcha y asociadas a la comprensión, gracias a la identificación de cómo realizan el muestreo, la predicción, la anticipación, la confirmación y la autocorrección. Lo anterior unido a la modelación por parte del investigador en el desarrollo de tareas, la transferencia paulatina del control en la ejecución de las mismas y el automonitoreo de los sujetos, permite el traspaso de la responsabilidad y la conquista de la autorregulación, imponiéndose los estímulos y la motivación interna sobre la externa a partir del autoconocimiento de cómo se comprende y que se hace mientras se comprende.

Un sujeto alfabetizado visualmente podrá identificar los elementos constitutivos de las imágenes visuales, lo que representan y su situación de producción. 
Adelantar intervenciones basadas en la alfabetización visual permite apoyar a los sujetos en la consolidación de procesos automáticos y el gobierno de los procesos controlados (Valle et al., 1990; De Vega y Cuetos, 1999). Se fortalece la competencia lingüística, la comprensión se ejecuta en favor de tareas, se aumenta y se mantiene la activación cuando la información es base para el procesamiento subsecuente o desactiva la información que resulte innecesaria. En consecuencia, los procesos de intervención para la comprensión en su gran mayoría priorizan los códigos verbales, ratificándose la tradición logocentrista y disminuyendo la variabilidad en el procesamiento textual que afecta la habilidad para realizar muestreo, producir inferencias, reflexionar y valorar la información. Adelantar procesos de alfabetización verbovisual proporciona beneficios derivados de la experiencia mediada que se manifiestan en el comportamiento adaptativo de los sujetos y el aumento en el grado de experticia en la comprensión.

La investigación pretende constituirse en una contribución a la investigación psicolingüística. Así, los procedimientos pueden servir de modelo para trabajos similares retomando los temas, los instrumentos y métodos; los resultados, que se muestran en los capítulos 4 y 5 , enriquecen el marco teórico general de la psicolingüística y, en consecuencia, de la lingüística de la comunicación; además, se constituye en un intento explicativo de las formas de representar la información y usar el conocimiento para interpretar las realidades discursivas que rodean a los sujetos.

Se proporciona el diseño de un dispositivo que puede ser replicado para corroborar o profundizar los aspectos abordados. Se destaca en él la elección de tipos de textos que en la mayoría de los casos se limita al mundo infantil, ignorando sus 
ventajas para otro tipo de público, su empleo como excusa atractiva para potencializar habilidades inherentes al uso del lenguaje. Se proponen experiencias desafiantes que confrontan al sujeto y exigen el cumplimiento de tareas complejas que facilitan la conquista de nuevos niveles de habilidades y procesos cognitivos gracias al refuerzo de conductas adaptativas. Adicionalmente se subraya que no solo los sujetos necesitan participar de intervenciones que consoliden su procesamiento verbovisual, los docentes que los acompañan deben ser partícipes de dicho proceso.

El estudio presenta limitaciones en su implementación relacionadas con la duración y la población estudiada. Se destaca que la duración de la investigación es de 14 sesiones, a pesar de la brevedad se obtuvieron resultados en el incremento del desempeño del grupo estudio, es claro que la ampliación en la aplicación podría traducirse en mayor información para analizar por parte del investigador e incremento en el desempeño de los sujetos y el aseguramiento de la permanencia de los cambios estructurales en la modificabilidad de la compresión. Es posible que la suspensión del entrenamiento conduzca a la ralentización de los procesos iniciados.

Teniendo en cuenta que la muestra es pequeña (10 sujetos grupo de estudio y 10 sujetos grupo control) desde el análisis estadístico se podrían discutir los resultados. Por ello, se apoyan los hallazgos en el análisis cualitativo, acudiendo al estudio de caso, se da cuenta del seguimiento a los procesos y se sacan conclusiones a la luz de la teoría psicolingüística.

Finalmente, se avanza en la modificabilidad en la comprensión de los sujetos del grupo de estudio porque la intervención verbovisual permite el reconocimiento y el análisis de los aspectos denotativos, connotativos y conceptuales de la imagen visual, y 
de los aspectos microestructurales, superestructurales, macroestructurales en los textos partiendo de las claves lingüísticas. Los ejercicios cognitivos, los juegos de estrategia, el abordaje de la fundamentación sobre la imagen visual y el procesamiento permanente de cuentos gráficos, permite que los sujetos mejoren en el muestreo, la producción de inferencias, la reflexión y la evaluación de la información. Lo expresado conduce a confirmar la hipótesis general de la investigación: la información de carácter visual resulta subsidiaria del procesamiento de la información verbal y requiere, al igual que esta última, de estrategias para su análisis. El desarrollo de estrategias específicas en el sujeto lector favorece la comprensión del texto verbovisual. 


\section{LISTA DE REFERENCIAS}

Abril, G. (2007). Análisis crítico de textos visuales. Síntesis.

Acaso, M. (2009). El lenguaje visual. Paidós.

Alberich, J., Gómez, D., Ferrer, A. (s.f.). Percepción visual. Universitat Oberta de Catalunya.

https://www.exabyteinformatica.com/uoc/Disseny grafic/Diseno grafico/Diseno graf ico (Modulo 1).pdf

Anula Rebollo, A. (1998). El abecé de la psicolingüística. Arco / Libros.

Arizpe, E. y Styles, M. (2004). Lectura de imágenes, los niños interpretan textos visuales. Fondo de Cultura Económica.

Arzaluz, S. (2005). La utilización del estudio de caso en el análisis local. Religión y Sociedad, XVII (32), pp. 107-144.

Atkinson, R. y Shiffrin, R. (1968) Memoria humana: un sistema propuesto y sus procesos de control. En K. Spence y J. Spence (Eds.), La psicología del aprendizaje y la motivación, Vol 2 (pp. 89-195). Academic Press.

Aumont, J. (1992). La imagen. Paidós.

Baddeley, A. (1998). Memoria humana: teoría y práctica. McGraw Hill.

Bajo, M., Puerta-Melquizo, M., Gómez, C. (1999). Representación semántica y fonológica de dibujos y palabras: ¿acceso diferencial o sistemas de memoria?”. Psicothema, 11 (4), pp. 873-889.

Bajtín, M. (1986). Estética de la creación verbal. Siglo XXI.

Baldó, F. (2016). Hostil y abyecto. Locorabia editores. 
Ballesteros, S. (1999). Memoria humana: Investigación y teoría. Psicothema. 11(4), pp. 705-723.

Barthes, R. (1986). Retórica de la imagen, en Lo Obvio y lo Obtuso. Paidós.

Beato, M., Díez, E., Pinho, M. y Rodrigues, M. (2006). Adaptación al castellano del cuestionario de viveza de imágenes visuales. Psicothema. 18 (4), pp. 711-716.

Belinchón, M., Riviére, A., Igoa, J. (1992). Psicología del lenguaje. Investigación y teoría. Trotta.

Bischoff, L. y Bocquet, O. (2015). Los gritos del pasado. Maeva Ediciones.

Boix, J. (2009). Grandes de lo macabro. Ediciones B.

Bonache, J. (1999). El estudio de casos como estrategia de construcción teórica: características, críticas y defensas. Cuadernos de economía y dirección de la empresa, (3), pp. 123-140.

Bono Cabré, R. (s.f.) Diseños cuasi-experimentales y longitudinales. Universidad de Barcelona.

http://diposit.ub.edu/dspace/bitstream/2445/30783/1/D.\%20cuasi\%20y\%20longitudin ales.pdf

Bruning, R., Norby, M. y Schrau, G. (2005). Psicología cognitiva y de la instrucción. Prentice Hall Pearson.

Campos, A. y González, M. (1994). Imagen, inteligencia y creatividad. Psicothema. 6 (3), pp. 387-393.

Carr T., McCauley, C., Sperber, R., y Parmelee, C. (1982). Palabras, imágenes y priming: sobre la activación semántica, la identificación consciente y la automaticidad del procesamiento de la información. Journal of Experimental Psychology: Human 
Perception and Performance, (8), pp. 757-777. https://psycnet.apa.org/record/198320255-001, https://www.ncbi.nlm.nih.gov/pubmed/6218234.

Carretero, M. (1995). Razonamiento y comprensión. Trotta.

Cedillo, I. (2010). El Aprendizaje mediado y las operaciones mentales de comparación y clasificación. [Tesis de maestría, Universidad de Cuenca]. Repositorio Institucional. http://dspace.ucuenca.edu.ec/handle/123456789/3296

Clark, J. y Paivio, A. (1991). Teoría de la codificación dual y educación. Educ Psychol Rev (3), pp. 149-210. https://doi.org/10.1007/BF01320076

Congreso de la República de Colombia (1982, 19 de febrero). Ley 23 de 1982 Sobre derechos de autor. Diario Oficial 35949. https://normograma.info/men/docs/pdf/ley 0023 1982.pdf

Corben, R. (2016). La guardia del horror: H.P. Lovecraft. Panini Cómics.

Daniel, W., Villamizar, J. y Ardila, G. (1997). Estadística con aplicaciones a las ciencias sociales y a la educación. Mc Graw Hill.

De Vega, M. (1984). Introducción a la psicología cognitiva. Alianza.

De Vega, M. (1990) Lectura y comprensión: Una perspectiva cognitiva. Alianza.

De Vega, M. y Cuetos, F. (1999). Psicolingüística del español. Trotta.

De Vega, M. y Díaz, J (2003). Modelos de situación e inferencias en la comprensión de textos. En J. León (Ed.), Conocimiento y discurso. Claves para inferir y comprender (pp. 139-152). Pirámide.

Delgado, J. (Julio de 2005). Una experiencia de creatividad verbo-icónica. una experiencia creativa de interrelación de lenguajes. Creación Integral. Recuperado 7 de febrero de 2019 en: http://www.iacat.com/revista/recrearte/recrearte02/jdelgado01.htm 
Durso, F y Johnson, M. (1980). Los efectos de las tareas de orientación sobre el reconocimiento, el recuerdo y la confusión de modalidades de imágenes y palabras. Journal of Verbal Learning and Verbal Behavior, 19 (4), pp. 416-429. https://doi.org/10.1016/S0022-5371(80)90294-7

Echevarría, Luis (2017). Modelos explicativos de las funciones ejecutivas. Descargado: file:///C:/Users/HP/Downloads/13534-Texto\%20del\%20art\%C3\%ADculo-47555-210-20170818.pdf

Farah, M. y Mcclelland, J. (1992). Un modelo computacional de deterioro de la memoria semántica: especificidad de modalidad y especificidad de categoría emergente. Revista de Psicología Experimental General, 120(4), pp. 339-357. https://www.researchgate.net/publication/21319277_A_Computational_Model_of_Se mantic Memory Impairment Modality_Specificity and Emergent_Category Specifi city

Ferradini, S. y Tedesco, R. (1997). Lectura de la imagen. Comunicar, (8), pp157 -160. Feuerstein, R. (1990). The theory of structural cognitive modifiability. En B. Presseisen (Ed.), Learning and thinking styles: classroom interaction (pp. 68-134). National Education Association. https://files.eric.ed.gov/fulltext/ED327322.pdf\#page=69

Feuerstein, R., Klein, P. y Tannenbaum, A. (1999). Mediated learning experience: Theoretical, psychosocial, and learning implications. Freund Publishing House.

Flyvbjerg, B. (2004). Cinco malentendidos acerca de la investigación mediante los estudios de caso. Revista española de investigaciones sociológicas, 106 (4), pp. 33-62.

Fodor, J. (1983). La modularidad en la mente. MIT Press.

Fonseca, N. (1995). Volumen de pruebas de aptitud. Educar. 
Fuentes, S. (2011). Análisis de conglomerados. Universidad Autónoma de Madrid. http://www.fuenterrebollo.com/Economicas/ECONOMETRIA/SEGMENTACION/CO NGLOMERADOS/conglomerados.pdf

García Madruga, J. y Fernández, T. (1992). Comprensión lectora y memoria operativa: Aspectos evolutivos e instruccionales. Paidós.

García, S. (2010). La novela gráfica. Astiberri.

Glaser, W.R. (1992). Nombre de imagen. Cognition, (42), pp. 61-105.

Glock, C. y Jaber, M. (2014). A group learning curve model with and without worker turnover. Journal of Modelling in Management, 9 (2), pp 179-199. https://www.researchgate.net/publication/265857991 A group learning curve mod el with and without worker turnover

Gómez, J. (s.f.). Módulo de lectura de imágenes fijas.

http://dibujoyartesplasticas.wikispaces.com/file/view/IMA.+LECTURA+DE+IMAGEN ES+FIJAS.pdf

González, P., Núñez, J., Álvarez, L.; Vallejo, G. (1998). Autoconcepto y su relación con la alineación de los ejes visuales. Psicothema. 10 (2), pp. 413-422.

Goodman, K. (1998). El proceso de la lectura: consideraciones a través de las lenguas y del desarrollo. En E. Ferreiro y M. Gómez, Nuevas perspectivas sobre los procesos de lectura y escritura (pp. 13-28). Siglo XXI.

Graesser, A. C, Singer M. y Trabasso, T. (1994) Construir inferencias durante la comprensión de textos narrativos. Psychological Review, 101 (3), pp. 371-395. https://doi.org/10.1037/0033-295X.101.3.371 
Graesser, A. C. y Bertus, L. (1998). The construction of causal inferences while reading expository texts on science and technology. Scientific Studies of Reading, (2), pp. 247-269.

Graesser, A. C. y Bower, G. (1990). Inferences and text comprehension. Academic Press.

Graesser, A. C. y Kreuz, R. (1993). A theory of inference generation during text comprehension. Discourse Processes, (16), pp. 145-160.

Groupe $\mu$ (1993). Tratado del signo visual. Para una retórica de la imagen. Cátedra.

Gundermann, H. (2004). El método de los estudios de casos. En M. Tarrés (Ed.), Observar, escuchar y comprender. Sobre la tradición cualitativa en la investigación social (pp. 231-264). El Colegio de México/FLACSO.

Gutiérrez-Calvo, M. (2003). Memoria operativa e inferencias en la comprensión del discurso. En J. León (Ed.), Conocimiento y discurso. Claves para inferir y comprender (pp. 123-138). Pirámide.

Haberlanot, K. (2003). Métodos experimentales en la investigación del discurso escrito. En J. León (Ed.), Conocimiento y discurso. Claves para inferir y comprender (pp. 6998). Pirámide.

Halliday, M (1978). El lenguaje como semiótica social. Fondo Cultura económica.

Hardy T. y Jackson, R. (2003). Aprendizaje y cognición. Prentice Hall Pearson.

Hergé (2012). Las aventuras de Tintín en América. Juventud.

Hernández Sampieri, R, Fernández Collado, C. y Baptista Lucio, P. (2010). Metodología de la Investigación. McGrahaw Hill.

Hoster, B. y Gómez, A. (2013). Interpretación de álbumes ilustrados como recurso educativo para la competencia literaria y visual. Red Visual, (19), pp. 65-76. 
https://idus.us.es/bitstream/handle/11441/57719/redvisual19 06 hostergomez.pdf?sequence $=1$

Johnson, C, Paivio, A. y Clark, J (1996). Componentes cognitivos de la denominación de imágenes. Boletín psicológico, 120 (1), pp. 113-139. https://doi.org/10.1037/00332909.120.1.113.

Kintsch, W. (1993). Information accretion and reduction in text processing: Inferences. Discourse Processes, (16), pp. 193-202. https://www.tandfonline.com/doi/abs/10.1080/01638539309544837

Kintsch, W. (1998). Comprehension: A paradigm for cognition. Cambridge University Press.

Krees, G. y Van-Leeuwen, T. (2001). Discurso multimodal. Los modos y los medios de la comunicación contemporánea. Arnold.

Kress, G y Threadgold, T. (1988). Towards a social theory of genre. Southern Review, 21 (3), pp. 215-243.

Kress, G. (2003). El alfabetismo en la era de los nuevos medios de la comunicación. Aljibe.

Kress, G. y Bezemer, J. (Diciembre de 2009). Cambio de texto: un análisis semiótico social de los libros de texto. https://www.researchgate.net/publication/291416065_Changing_Text A Social_Se miotic Analysis of Textbooks

Lalia, H. (2008a). La mano del mundo y otras historias de horror. Ediciones Colihue. Lalia, H. (2008b). Los ojos de la pantera y otras pesadillas. Ediciones Colihue. 
León, J. (1991). La comprensión y el recuerdo de los textos expositivos a través de análisis de algunas variables del texto y el lector. En Infancia y Aprendizaje: Journal for the Study of Education and Development, (56), pp. 51-60.

León, J. (2001). Las inferencias en la comprensión e interpretación del discurso: Un análisis para su estudio e investigación. Signos, 34 (49 -50), pp. 113 -125.

León, J. (2007). Procesos inferenciales en la comprensión del discurso escrito influencia de la estructura del texto en los procesos de comprensión. Signos, 40 (64), pp. 311336.

León, J. (Ed.). (2003). Conocimiento y discurso. Claves para inferir y comprender. Pirámide.

León, J., Escudero, I., Van-Den-Broek, P. (2003). La influencia del género del texto en el establecimiento de inferencias elaborativas. En J. León (Ed.), Conocimiento y discurso. Claves para inferir y comprender (pp. 153-170). Pirámide.

Linero, R. (s.f.). La imagen fija: la fotografía y el cómic. http://www.contraclave.es/nntt/medios/fotocomic.pdf

Lohr, S. (2000). Muestreo: diseño y análisis. Thomson editores.

López, M., Castañeda, S. y Gómez, T. (1989). Contribución a la evaluación de estrategias de aprendizaje. El inventario de habilidades de estudio. En Antología. La psicología cognoscitiva del aprendizaje (pp. 281-288). Universidad Nacional Autónoma de México.

López-Roldán, P. y Fachelli, S. (2015). Metodología de la investigación social cuantitativa. Libro digital Creative Commons. https://ddd.uab.cat/pub/caplli/2016/163564/metinvsoccua a2016 cap1-2.pdf 
Lorenzo, J. (5 de marzo de 2013). Perspectiva histórica de las investigaciones psicológicas en lectura.

https://ansenuza.unc.edu.ar/comunidades/bitstream/handle/11086.1/744/03\%20Mod elo $\% 20 \mathrm{de} \% 20$ comprension $\% 20 \mathrm{de} \% 20$ textos.pdf?sequence=1\&isAllowed=y

MacDonald, M., Pearlmutter, N. y Seidenberg, M. (Noviembre de 1994). Lexical nature of syntactic ambiguity resolution. Psychological review. https://www.researchgate.net/publication/15213953 Lexical nature of syntactic a mbiguity resolution

Maclure, S. y Davies, P. (1994). Aprender a pensar, pensar en aprender. Gedisa.

Magliano, J. y Graesser, A. (1991). A three-pronged method for studying inference generation in literary text. Poetics, (20), pp. 193-232.

https://www.sciencedirect.com/science/article/abs/pii/0304422X9190007C?via\%3Dih $\underline{\mathrm{ub}}$

McCloud, Scott (2008). Entendiendo el cómic. Estudios sociales, (30), pp. 114-123. https://doi.org/10.7440/res30.2008.11

Mckoon, G., y Ratcliff, R. (1992). Inference during reading. Psychological Review, (99), pp. 440-466.

Merrian, S. (1998). Qualitative Research and Case Study Applications in Education. Jossey-Bass Publishers.

Meter, P. y Yelin, B. (2010). Veneno. Sinsentido.

Molina, E. (2014). Lo mejor de Poe. Ediciones de la Flor.

Molinari Maroto, C. (1996). Introducción a los modelos cognitivos de la comprensión del lenguaje. Eudeba. 
Morales, M., Domínguez M. y Jurado, T. (2000). Diseños de respuesta múltiple: aplicación de la teoría de la detección de señales de análisis de la inferencia visual de series de tiempo. Psicothema, 12 (2), pp. 396-398.

Morhain, J., Túnica, M., Túnica, P. (2015). El retrato de Dorian Gray de Oscar Wilde, versión gráfica. Latinbooks.

Morhain, J., Túnica, M., Túnica, P. (2016). El corazón de las tinieblas. de Joseph Conrad, versión gráfica. Latinbooks.

Muth, D. (1990). El texto expositivo, estrategias para su comprensión. Aique grupo editor.

Nelson, D., Reed, V y Wallina, J (1976, octubre) Efecto de superioridad pictórica. Revista de psicología experimental Aprendizaje y Memoria humana, 2 (5), pp. 523-528. https://www.researchgate.net/publication/22152101_Pictorial superiority effect

Nelson, D., Reed, V. y McEvoy, C. (1977). Aprender a ordenar imágenes y palabras: un modelo de codificación sensorial y semántica. Revista de psicología experimental Aprendizaje y Memoria humana, 3 (5), pp. 485-497.

https://psycnet.apa.org/doi/10.1037/0278-7393.3.5.485

NGV (s.f.). Gimnasia mental tomo 2.

Nikolajeva, M. y Scott, C. (2001). How Picturebooks Work. Garland Publishing.

Niño, D. (Ed.). (2008). Ensayos semióticos. Fundación Universitaria de Bogotá Jorge Tadeo Lozano.

Noguez, S. (2002). El desarrollo del potencial de aprendizaje: Entrevista a Reuven Feuerstein. Scielo, 4 (2). http://www.scielo.org.mx/scielo.php?script=sci arttext\&pid=S1607$\underline{40412002000200009}$ 
Oesterheld, H. y Breccia, A. (2013). El Eternauta y otras historias. Ediciones Colihue.

Orrú, S. (2003). Reuven Feuerstein y la teoría de la modificabilidad cognitiva estructural. Revista de educación, (332), pp. 33-54.

https://dialnet.unirioja.es/servlet/articulo?codigo $=776714$

Ossa, F. (2019). Cómic, la aventura infinita. Planeta.

Parodi, G (2010). Multisemiosis y lingüística de corpus: artefactos (multi)semióticos en los textos de seis disciplinas en el corpus pucv-2010. Revista de Lingüística Teórica y Aplicada, 48(2), pp. 33-70. https://dx.doi.org/10.4067/S0718-48832010000200003

Parodi, G. (2005). Comprensión de textos escritos. Eudeba.

Parodi, G. (2014). Lingüística de corpus. De la teoría a la empiria. Iberoamericana Editorial Vervuert.

Pascual, J., Frías D. y García F. (1996). Manual de psicología experimental: metodología de investigación. Ariel.

Pérez, D. (1994). Propiedades tridimensionales de la escena visual y discriminación preatentiva de texturas. Psicothema, 6 (3), pp 469-482.

Perfetti, Ch. y Bell, L. (1991). Activación fonémica durante los primeros 40 ms de identificación de palabras: evidencia de enmascaramiento y cebado hacia atrás. Revista de memoria y lenguaje, 30 (4), pp. 473-85. https://www.sciencedirect.com/science/article/pii/0749596X9190017E

Piovanni, J., Rausky, M. y Santos, J. (2011). Definiciones metodológicas del case study en publicaciones tempranas del American Journal of Sociology (1915-1934). En Gallegos, C. y Lince, R., Reflexiones latinoamericanas sobre metodología de las 
ciencias sociales, I. Unison-UNAM.

https://periferiaactiva.files.wordpress.com/2014/09/piovani-rausky-santos.pdf

Powell, M. y Break, J. (2017). El mago de Oz de Frank Baum, versión gráfica. Latinbooks.

Pratt, H. (2003). Corto Maltés. Norma.

Puerto, M. (2015). Leer con imágenes, dibujar con palabras. La comprensión lectora mediada por el libro álbum. [Tesis de maestría, Universidad Distrital Francisco José de Caldas]. Repositorio Institucional.

https://repository.udistrital.edu.co/handle/11349/2135

Quino (2010). Toda Mafalda. Ediciones de la Flor.

Ragin, Ch. (2000). Introduction: cases of what is a case?. En Ch. Ragin y H. Becker (Eds.), What is a case: exploring the foundations of social inquiry. Cambridge University Press.

Ridgeway, F. (1987). Don Abundio \#1. Oveja Negra.

Rojas, E. (2013). Cómic visto a través del diseño gráfico. Zetta Comunicadores.

Sáiz, D., Baqués, J. y Sáiz, M. (1999). Factores que pueden mejorar la codificación de los mensajes publicitarios: una cuestión de memoria implícita o explícita. Psicothema, 11 (4), pp. 891-900.

Salas, P. (2012). El desarrollo de la comprensión lectora en los estudiantes del tercer semestre del nivel medio superior de la Universidad Autónoma de Nuevo León. [Tesis de maestría, Universidad Autónoma de Nuevo León]. Repositorio Institucional. http://eprints.uanl.mx/3230/1/1080256466.pdf

Salisbury, M. y Styles, M. (2012). El arte de ilustrar libros infantiles. Concepto y práctica de la narración visual. Blume. 
Sánchez Meca, J. e Hidalgo Montesinos, M. (1990). Implicaciones de la codificación visual en el retraso específico en lectura. Psicothema, 2 (2), pp. 35-48.

Sánchez, M., Padial-Ruiz, E., Pérez, N., Fernández, M., Cobos, P., y Vila, J. (2002). Modulación emocional de los reflejos defensivos mediante visualización de imágenes afectivas. Psicothema, 14 (4), pp. 702-707.

Scarborough, D., Gerard, L. y Cortese, Ch. (1979) Acceso a la memoria léxica: la transferencia de los efectos de repetición de palabras entre tareas y modalidades. Memoria y cognición, 7(1), pp. 3-12. https://link.springer.com/content/pdf/10.3758/BF03196928.pdf

Schilling, M., Vidal, P., Ployhart, R. y Marangoni, A. (2003). Learning by Doing Something Else: Variation, Relatedness, and the Learning Curve. Ciencias de la gestión, 49 (1), pp. 39-56.

https://www.researchgate.net/publication/209410063 Learning by Doing Somethin g_Else Variation Relatedness and the Learning Curve

Schmalhofer, F., McDaniel, M. y Keefe, D. (2002) Un modelo unificado para inferencias predictivas y puente. Procesos del discurso, 33 (2), pp. 105-132. https://www.researchgate.net/publication/228793438 A Unified Model for Predicti ve and Bridging Inferences

Schulz, Ch. (2012). Lo mejor de Carlitos y Snoopy. Random House.

Sebastián, M. y Menor, J. (1999). La evaluación de la memoria implícita mediante la tarea de identificación perceptiva de dibujos fragmentados. Psicothema, 11 (4), pp. 815 830. 
Siegel, S. y Castellan, J. (1995). Estadística no paramétrica aplicada a las ciencias de la conducta. Trillas.

Sierra, B., Cuevas, I., López-Frutos, J. (1995). El efecto de las imágenes sobre el recuerdo de atributos del producto en anuncios impresos. Psicothema, 7 (2), pp. 249-266.

Snodgrass, J. y Corwin, J. (1988). Pragmatics of Measuring Recognition Memory:

Applications to Dementia and Amnesia. Journal of Experimental Psychology:

General, 117 (1), pp. 34-50

Sperber, R., McCauly, Ch., Ragain, R y Weil, C. (1979). Efectos de imprimación semántica en la imagen y el procesamiento de textos. Memoria y cognición, 7 (5), pp. 339-345. https://link.springer.com/content/pdf/10.3758/BF03196937.pdf

Stake, R. (1998). Investigación con estudios de caso. Morata.

Stake, R. (2003). Case studies. En N. Denzin y estudies. Lincoln (Eds.) Strategies of qualitative inquiry. Sage-Toushand oaks.

Steiner, M. (2012). Comprender las imágenes. Entre las formas simbólicas y los procesos culturales. Cuadernos del Centro de Estudios de Diseño y Comunicación, (39), pp. 71-84.

https://fido.palermo.edu/servicios dyc/publicacionesdc/cuadernos/detalle articulo.ph p?id libro=346\&id articulo=7824

Storkel, H y Adlof, S. (1 de abril de 2009). Vecinos semánticos adultos y niños de los no objetos de Kroll y Potter. Journal of speech, languae, and hearing research. https://pubs.asha.org/doi/10.1044/1092-4388\%282009/07-0174\%29

Tapia, J. (2005). Claves para la enseñanza de la comprensión lector. Revista de Educación, pp. $63-93$. 
https://www.researchgate.net/publication/28161112 Claves para la ensenanza de la comprension lectora

Torres, M (2007, 22 de junio). Imagen y comunicación: la alfabetización visual. La práctica pedagógica en la Básica y la Media.

https://raulroldana.wordpress.com/2007/06/22/imagen-y-comunicacion-laalfabetizacion-visual/

Trabasso, Thomas y Magliano, Joseph (1996). Conscious understanding during text comprehension. Discourse Processes, (21), pp. 255-287.

Trachte, D. (1987). Henry \#6. Oveja Negra.

Valle Arroyo, F. (1992). Psicolingüística. Morata.

Valle Arroyo, F., Del Viso, S., Igoa, J. y Cuetos, F. (1990). Lecturas de psicolingüística. Alianza.

Van Dijk, T y Kintsch, W. (1983). Estrategias de comprensión del discurso. Academic Press.

Vernon - Lord, J. (1997). Algunos aspectos que el ilustrador debe tener en cuenta en el proceso de la creación de los libros ilustrados para niños [sesión de conferencia]. IV Sinpost Internacional Catalònia d’II.lustració, Barcelona, Generalitat de Catalunya.

Villa, N. (2008). Propuesta de alfabetización visual para estudiantes de educación básica apoyada en recursos hipermediales. Un aporte a la comprensión lectora. Revista Interamericana de Bibliotecología. 31 (1), pp. 207-225.

Villafañe, J. (2006). Introducción a la teoría de la imagen. Pirámide. 
Villar, A. (2016) El álbum ilustrado: un género en alza. https://academica-

e.unavarra.es/bitstream/handle/2454/21081/Albumllustrado.pdf?sequence=1\&isAllo $\underline{\text { wed }=\mathrm{y}}$

Vonk, W. y Noordman, L. (1990). Sobre las inferencias en la comprensión de textos. En D. Balona, G. Flores y K. Rayner (Eds.), Procesos de comprensión en la lectura, pp. 447-464. Lawrence Erlbaum Associates. https://books.google.com.co/books?id=zfshAwAAQBAJ\&pg=PA89\&lpg=PA89\&dq=V onk+y+Noordman+(1990)\&source=bl\&ots=DfbCuTDORI\&sig=ACfU3U2xc7r06C $5 \mathrm{kul}$ z1xeXjY3IQ0-x2Mw\&hl=es-

419\&sa=X\&ved=2ahUKEwi08ljWu5zkAhVDo1kKHRG6CCkQ6AEwCnoECAgQAQ\# v=onepage $\& \mathrm{q}=$ Vonk $\% 20 \mathrm{y} \% 20$ Noordman $\% 20(1990) \& \mathrm{f}=$ false

Yin, R. (2009). Case study research. Sage.

Yomtov, N y Smith, T. (2011). Teseo y el minotauro. Latinbooks.

Zavala, L. (s.f.). Los componentes formales de la narrativa gráfica - La historieta clásica: el formato fundamental. https://docplayer.es/67777427-Los-componentes-formales-dela-narrativa-grafica.html 
ANEXOS 


\section{ANEXO 1. Prueba pretest. El testamento del señor Morris (Boix, 2009, pp. 59-65)}

Los cuentos gráficos empleados en la intervención no se anexan en ninguna parte de la tesis para respetar los derechos de autor, para leer consultar la bibliografía correspondiente.

INSTRUCCIÓN. Partiendo de la lectura del anterior texto, responda las siguientes preguntas de selección de múltiple con única respuesta.

1. Si se observa detenidamente la primera viñeta de la página 1 se puede concluir que:

a. Paul vive en una zona urbana pobre

b. Paul vive en zona rural pobre

c. Paul vive en una zona urbana acaudalada

d. Paul vive en una zona rural acaudalada

2. El carácter de Paul está predeterminado por:

a. su profesión porque los artistas son sensibles

b. sus padres porque así lo educaron

c. sus decisiones porque han sido acertadas

d. su experiencia porque ha enfrentado situaciones difíciles

3. Si el señor Morris estaba hipnotizado por qué estaba consciente del poco agrado que sentía hacia sus sobrinos: 

a. porque sus palabras no los controlaba la hipnosis.
b. porque la hipnosis controlaba sus palabras.
c. porque sus sentimientos los controlaba la hipnosis.
d. porque la hipnosis no contralaba sus sentimientos.

4. Según lo observado en las imágenes la historia pudo ocurrir:
a. durante el siglo XIX.
b. segunda mitad del siglo $X X$.
c. primera mitad del siglo $X X$.
d. luego del siglo XIX.

5. Teniendo en cuenta las páginas 6 y 7, los sobrinos del señor Morris identificaron en el doctor:
a. duda e inseguridad
b. nervio y remordimiento
c. nervio e inseguridad
c. duda y remordimiento

6. El cuento gráfico se puede calificar como:
a. policiaco.
b. suspenso.
c. crónica.
d. romántico. 
7. Las escenas que se consolidan como parte central de la historia se encuentran en las páginas:
a. 2, 3 y 4 de manera descendente
b. 2, 3 y 4 de manera ascendente
c. 4,5 y 6 de manera ascendente
d. 4,5 y 6 de manera descendente

8. Las viñetas 4,5 y 6 de la página 6 progresa desde un primerísimo a plano detalle, se puede afirmar que el anterior recurso el autor lo emplea para:

a. contextualizar los hechos mostrando un elemento que es la parte de un todo.

b. mostrar los ojos como espejos del alma que evidencian el alma deshonesta del doctor

c. indicar que el oficio del personaje se centraba en dominar desde los ojos de sus clientes

d. reforzar el interés sobre un elemento que causa sensación de tensión, emoción e intimidad.

9. La viñeta 3 de la página 1 y la viñeta 5 de la página 2 según la retórica de la imagen corresponde a ejemplos de:

a. metonimia porque se designa una cosa con el nombre de otra respetando cierta relación de sentido 
b. sinécdoque porque representan el todo a partir de una parte haciendo énfasis en lo que se desea resaltar

c. prosopopeya porque se caracteriza una realidad no humana como humana asignándole ciertos atributos

d. metáfora porque se presenta la información, pero con un significado distinto para reforzarlo

10. El final del texto se puede catalogar como:

a. inesperado porque este rebasa todas las expectativas que el lector contempló hasta el momento del clímax.

b. natural porque está ligado a la línea del argumento, no sorpresivo, sino lógico, consecuente.

c. contundente porque se encuentra en la última frase del cuento.

d. flotante porque se basa en sobreentendidos, sólo el lector tiene pistas claras, sugerencias que les ayuden a definirlo. 


\section{ANEXO 2. Prueba de monitoreo 1. El secreto de la cañada de Macarger (Lalia, 2008B, pp. 73-79)}

Los cuentos gráficos empleados en la intervención no se anexan en ninguna parte de la tesis para respetar los derechos de autor, para leer consultar la bibliografía correspondiente.

INSTRUCCIÓN. Partiendo de la lectura del anterior texto, responda las siguientes preguntas de selección de múltiple con única respuesta.

1. El título del cuento "El secreto de la cañada de Macarger" se refiere a:

a. la verdad sobre eventos paranormales que suceden en la cañada de Macarger.

b. la vida oculta de una mujer en la cañada de Macarger

c. la vida secreta del fantasma en la cañada de Macarger

d. la verdad sobre los detalles de sucesos violentos que ocurrieron en la cañada de Macarger

2. En la página 2 el cazador sufre una perturbación de su:

a. percepción y tranquilidad

b. tristeza y agudeza

c. sueño y espíritu

d. concentración y angustia 
3. Durante el sueño se concluye que el cazador experimentó una liberación de:
a. energía
b. recuerdos
C. sentimientos
d. existencia

4. En la página 3 y 4 se muestran momentos intensos que vivió el cazador, estos se pueden catalogar como una experiencia:
a. ocultista
b. inductiva
b. psíquica
d. religiosa

5. Las imágenes visuales y la expresión de la página 4, viñeta 2: "Todo se hizo tan confuso y desperté. Mis temores se desaparecieron", permiten identificar en el personaje:
a. tranquilidad y paz
b. desvelo y zozobra
c. inseguridad y perplejidad
d. bienestar y desasosiego

6. El sueño del cazador se antepone al descubrimiento de:

a. los espectros en la cañada de Macarger 
b. el homicida de la cañada de Macarger.

c. la mujer en la cañada de Macarger

d. la historia de la cañada de Macarger

7. Según lo observado en las imágenes la historia del asesinato pudo ocurrir:

a. la noche misma cuando el cazador se quedó en la cabaña

b. las noches anteriores de que el cazador se quedara en la cabaña

c. la noche misma mientras el cazador dormía en la cabaña

d. las noches posteriores de que el cazador se quedara en la cabaña

8. La viñeta 4 de la página 6 , las viñetas 2,5 y 6 de la página 7 permiten deducir que los actos descontrolados de algunos de los personajes se deben a que experimentaban:
a. confusión y nervios
b. espanto y curiosidad
c. intranquilidad y dolor
d. torpeza y desatención

9. Las viñetas de página 4 permiten deducir que el cazador se encontraba en estado de:

a. inconsciencia porque el personaje bloquea los sentimientos abrumadores que alcanzan la conciencia 
b. somnolencia porque el personaje se encuentra entre el sueño y la vigilia en el que todavía no ha perdido la conciencia.

c. posesión porque el personaje es controlado por almas errantes que alteran su comportamiento.

d. premonición porque el personaje conoce de forma paranormal los sucesos acontecidos en el lugar

10. Las expresiones corporales y las intervenciones del personaje de traje de puntos que aparece en la viñeta 4 de la página 6 , las viñetas 2,5 y 6 de la página 7 le proporcionan al cuento:

a. desacralización porque disminuye el carácter sagrado de los sucesos

b. carnavalización porque se aparta de la tradición para burlarse de las acciones

c. comicidad porque ridiculiza las acciones para lograr divertir

d. trivialización porque les quita importancia a los hechos 


\section{ANEXO 3. Prueba de monitoreo 2. El mal (Boix, 2009, pp. 86-90)}

Los cuentos gráficos empleados en la intervención no se anexan en ninguna parte de la tesis para respetar los derechos de autor, para leer consultar la bibliografía correspondiente.

INSTRUCCIÓN. Partiendo de la lectura del anterior texto, responda las siguientes preguntas de selección de múltiple con única respuesta.

Preguntas tipo I de selección múltiple con única respuesta.

1. En el cuento se busca realizar una:

a. crítica pero no una advertencia

b. advertencia pero no una crítica.

c. advertencia y también una crítica.

d. crítica y también una advertencia.

2. En el contexto del cuento gráfico, la connotación de la palabra mal se interpreta desde una perspectiva:

a. religiosa

b. biológica

c. axiológica

d. filosófica 
3. La expresión de la página 2 "Soy un elemento imprescindible de la naturaleza" (viñeta 1 de la página 2) implica que Mal es necesario para:

a. generar acciones en la vida de los seres humanos.

b. mantener el equilibrio de la naturaleza.

c. la convivencia de los seres humanos.

d. que exista la vida de los humanos y la naturaleza.

4. El escenario donde se muestra el personaje central evidencia:

a. ruina y oscuridad.

b. oscuridad y decadencia.

c. oscuridad y dificultad.

d. ruina y decadencia.

5. En la página 3, viñeta 4, cuando el personaje central se refiere al vocabulario insinúa que el mal se:

a. le atribuye a los humanos porque hablan.

b. relaciona con la facultad del habla.

c. le atribuye a la inteligencia de los humanos.

d. relaciona a la facultad de los humanos.

6. El discurso, la posición corporal y la ubicación del personaje permiten identificar prioritariamente en él:

a. elocuencia, desconcierto y remordimiento 
b. inteligencia, angustia y furia

c. paciencia, sabiduría y altivez

d. impertinencia, orgullo y rencor

7. La imagen de la luna llena que aparece repetidamente en el texto simboliza:

a. vanidad.

b. misticismo

c. frialdad.

d. romanticismo.

8. El Mal concluye su discurso con la palabra Justicia porque:

a. con el mal se consigue la justicia de los seres humanos.

b. con el mal se sustenta el vocabulario que logra la justicia.

c. el mal sustenta el vocabulario que logra la justicia humana.

d. con el mal los seres humanos consiguen la justicia.

9. En las páginas 3 y 4 se inicia en la primera viñeta con plano general y finaliza en la última viñeta con plano detalle, se puede afirmar que se utiliza el anterior recurso para: a. progresar desde una visión general del personaje y su contexto a una presentación agresiva e íntima donde se enfatiza la expresión facial que evidencia sinceridad en las palabras.

b. mostrar la evolución narrativa del texto que migra desde lo desconocido del mundo en penumbras a Mal al mensaje que comparte. 
c. embellecer el texto, revelar al personaje y su entorno desde diferentes enfoques que facilitan comprender el mensaje del texto.

d. destacar las diferentes escenas que se pueden utilizar en este tipo de textos independientemente de la temática abordada, las intenciones estilísticas y temáticas del autor.

10. La oscuridad, la noche y las características físicas de Mal le proporcionan densidad al texto que interactúa con lo expresado por el personaje porque se presenta una relación entre imagen visual-claves lingüísticas de:

a. ampliación porque los dos códigos se completan, la imagen extiende el significado del texto o el texto el de la imagen

b. complementaria porque uno de los dos códigos aporta información más significativa y distinta que el otro

c. contrapunto porque la imagen y el texto cuentan la historia de manera distinta o desde un ángulo diferente d. simétrica porque se asume que tanto las palabras como la imagen cuentan la historia de manera simultánea 


\section{ANEXO 4. Prueba de monitoreo 3. El estúpido humano (Boix, 2009, pp. 78-85)}

Los cuentos gráficos empleados en la intervención no se anexan en ninguna parte de la tesis para respetar los derechos de autor, para leer consultar la bibliografía correspondiente.

INSTRUCCIÓN. Partiendo de la lectura del anterior texto, responda las siguientes preguntas de selección de múltiple con única respuesta.

1. El mensaje del cuento es:

a. algunos humanos no aprovechan las oportunidades para alcanzar la felicidad.

b. algunos humanos no comprenden las oportunidades que los conducen a la felicidad.

c. algunos humanos no planean las oportunidades para alcanzar la felicidad.

d. algunos humanos no acogen las oportunidades que los conducen a la felicidad.

2. Teniendo en cuenta el diálogo que sostienen los personajes del cuento, figurativamente el oasis representa:

a. la felicidad del humano.

b. la felicidad de los humanos.

c. la felicidad del personaje.

d. la felicidad de los personajes. 
3. Con base en la conducta que asume Herbet hacia Keome, se puede afirmar que:

a. Keome siempre había sentido envidia hacia Herbet.

b. Keome no siempre había sentido envidia hacia Herbet.

c. Herbet siempre había sentido envidia hacia Keome.

d. Herbet no siempre había sentido envidia hacia Keome.

4. La piedra y la inscripción se configura para Herbet en:

a. la alucinación producto de la rabia e impotencia de Herbet y Keome.

b. un espejismo producto del efecto del desierto sobre Herbet y Keome.

c. la materialización de la inconformidad y los sentimientos negativos de Herbet hacia Keome.

d. una excusa de Herbert ratificar su desventaja ante Keome.

5. Teniendo en cuenta las expresiones faciales de Keome y la oración: "No me hace falta, Herbet, yo hallé el camino" (viñeta 4, página 3), se puede deducir que él lo dice para:

a. enterarlo de la verdad y tranquilizarlo

b. calmar a Herbet utilizando una mentira

c. salir del paso porque estaba desesperado

d. conducirlo al oasis gracias a una alucinación.

6. El cronotopo (relación espacio - tiempo) de la historia se resume en:

a. tres días y dos noches en el desierto. 

b. dos días y tres noches en el desierto.
c. tres días y tres noches en el desierto.
d. dos días y dos noches en el desierto.

7. Probablemente el autor escogió el desierto como escenario del relato por las condiciones que:
a. posee no son las adecuadas para el argumento de la historia.
b. proporciona son las adecuadas para el fin de la historia.
c. posee son las adecuadas para el argumento de la historia.
d. proporciona no son las adecuadas para el fin de la historia.

8. En las viñetas de la página 1 se inicia con un plano general y finaliza con un primer plano. Lo expuesto se usa para:

a. enfatizar en las dificultades físicas que experimentan los personajes que hacen evidentes conflictos personales.

b. destacar la importancia del Herbet frente a Keome.

c. mostrar que los personajes iniciaron su aventura juntos y después se separaron porque pelearon.

d. indicar que los personajes se trasladan por un espacio hostil.

9. Teniendo en cuenta la viñeta 4 de la página 2 , las viñetas 3 y 4 de la página 3 , se puede deducir que la relación entre Herbet y Keome es de:

a. competición porque luchan por dominar uno a otro 
b. depredación porque uno destruye al otro violentamente.

c. antibiosis porque algunas acciones de uno son perjudiciales para el otro.

d. mutualismo porque se asocian en beneficio de ambos

10. A través de las imágenes visuales y las intervenciones de Keome se puede concluir que se le representa como una persona:

a. engañosa, envidiosa y terca

b. amorosa, responsable y solidaria

c. irritable, solidaria, indiferente

d. paciente, justa y sabia 


\section{ANEXO 5. Prueba post test. La fobia (Boix, 2009, pp. 91-98)}

Los cuentos gráficos empleados en la intervención no se anexan en ninguna parte de la tesis para respetar los derechos de autor, para leer consultar la bibliografía correspondiente.

INSTRUCCIÓN. Partiendo de la lectura del anterior texto, responda las siguientes preguntas de selección de múltiple con única respuesta.

1. La conducta del personaje se desata por:

a. los ladridos del perro de la niña que él atropelló.

b. los ladridos del perro de la niña que él recuerda.

c. los ladridos del perro de la niña que él sonó.

d. los ladridos del perro de la niña que él se imaginó.

2. El espacio en el que se desarrolla la mayor parte de los hechos es en:

a. un calabozo.

b. una habitación.

c. una comisaría.

d. un manicomio.

3. La imagen de la niña que aparece en la página 3 connota:

a. sagacidad 

b. claridad
c. ternura
d. zozobra

4. La viñeta 5 de la página 6 , las viñetas 3 y 4 de la página 7 permiten suponer que el protagonista de la historia estuvo varios meses en:
a. una cárcel
b. un balneario
c. una clínica
d. un reformatorio

5. Se puede conjeturar que la verdadera razón por la que Juan se aleja de su esposa nuevamente es porque:
a. ya no la quiere como pareja.
b. presenta una crisis nerviosa.
c. fue solicitado por su empleador.
d. debe buscar un trabajo como ingeniero.

6. Un elemento que ayudó a transformar la imagen del perro de la niña en una bestia infernal fue:
a. la prisa
b. el frío
c. la noche 
d. el sueño

7. Teniendo en cuenta las viñetas de la página 8 , y en especial la expresión del personaje "fue un espectáculo horrible" que aparece en la viñeta 10, se puede intuir que se desea comunicar al lector tensiones emocionales asociadas a:

a. la sorpresa y el miedo

b. el agrado y el remordimiento

c. la tranquilidad y el pánico

d. la ansiedad y la culpa

8. El autor emplea repetidamente onomatopeyas como AAAAUUUUU, CLING, CLIC, CRACK, GUAU, ZAG. Se puede afirmar que el objetivo de ello es en el texto:

a. ser fiel a las raíces del cómic que utilizaban exageradamente este recurso

b. decorar el texto para que sea más llamativo al lector

c. enfatizar en lo tenebroso del ambiente partiendo de los ruidos y la confusión.

d. propiciar una aproximación más fiel a la realidad acudiendo a lo sinestésico.

9. En la viñeta 6 de la página 8 se emplea la sinécdoque como recurso retórico que permite suponer:

a. la experimentación de otro evento alucinativo del personaje central.

b. la muerte violenta de la niña y el perro como consecuencia de las acciones del personaje central. 
c. la ruptura de la estabilidad emocional del personaje central ocasionado por la soledad.

d. la confusión entre realidad y fantasía no solo del personaje central si no en la recepción del mensaje del cuento.

10. La mayoría de las viñetas muestran que los eventos se desarrollan en la oscuridad, el personaje transita desde la cordura hacia la esquizofrenia. Teniendo en cuenta la retórica de la imagen se puede afirmar que se acude al recurso de la:

a. metonimia porque se designa una cosa con el nombre de otra respetando cierta relación de sentido.

b. sinécdoque porque representan el todo a partir de una parte haciendo énfasis en lo que se desea resaltar.

c. prosopopeya porque se caracteriza una realidad no humana como humana asignándole ciertos atributos.

d. metáfora porque se presenta una idea, pero con un significado distinto para reforzarlo. 


\section{ANEXO 6. Consentimiento informado para proyectos de investigación}

\begin{tabular}{|l|l|}
\hline TíTULO: & $\begin{array}{l}\text { Las claves lingüísticas y la imagen visual en la comprensión de textos } \\
\text { verbovisuales narrativos: el cuento gráfico }\end{array}$ \\
\hline INVESTIGADOR: & Tatiana Gómez Bruno \\
\hline LUGAR: & Universidad de Córdoba \\
\hline
\end{tabular}

Estas hojas de consentimiento Informado pueden contener palabras que usted no entienda. Por favor pregunte al investigador principal para que le explique cualquier palabra o información que usted no entienda claramente. Usted puede llevarse a su casa una copia de este consentimiento para pensar sobre este estudio o para discutir con su familia o amigos antes de tomar su decisión.

\begin{tabular}{|c|c|}
\hline INTRODUCCIÓN: & $\begin{array}{l}\text { Usted ha sido invitado a participar en un estudio de investigación. } \\
\text { Antes de que decida participar en el estudio por favor lea este } \\
\text { consentimiento cuidadosamente. Haga todas las preguntas que usted } \\
\text { tenga, para asegurarse de que entienda los procedimientos del } \\
\text { estudio, incluyendo los riesgos y los beneficios. }\end{array}$ \\
\hline $\begin{array}{l}\text { PROPÓSITO DEL } \\
\text { ESTUDIO: }\end{array}$ & Este proyecto explorará \\
\hline $\begin{array}{l}\text { PARTICIPANTES DEL } \\
\text { ESTUDIO: }\end{array}$ & $\begin{array}{l}\text { El estudio es completamente voluntario. Usted puede participar o abandonar } \\
\text { el estudio en cualquier momento sin ser penalizado. Para este proyecto se } \\
\text { tendrá en cuenta que los estudiantes hagan parte de programas de la } \\
\text { Facultad de Educación y Ciencias Humanas de la Universidad de Córdoba. }\end{array}$ \\
\hline PROCEDIMIENTOS: & $\begin{array}{l}\text { Para la recolección de información relacionada con este estudio se solicitará } \\
\text { a los voluntarios responder pruebas de comprensión, realizar ejercicios, } \\
\text { participar en juegos, diligenciar un diario, encuestas y entrevistas. }\end{array}$ \\
\hline $\begin{array}{l}\text { RIESGOS O } \\
\text { INCOMODIDADES: }\end{array}$ & $\begin{array}{l}\text { En este estudio los participantes podrían sentir algún nivel de ansiedad o } \\
\text { presión respecto a su experiencia con los resultados de los diferentes } \\
\text { ejercicios; al mismo tiempo pueden sentir que se vulnera su privacidad, } \\
\text { puesto que todo el material que se recopile se analizará de forma exhaustiva } \\
\text { y se compartirá con la comunidad académica. Sin embargo, en ningún } \\
\text { momento del estudio, se juzgarán los desempeños de los estudiantes, al } \\
\text { contrario, estos serán la fuente de nuevos hallazgos investigativos. }\end{array}$ \\
\hline BENEFICIOS: & Debe quedar claro que usted no recibirá ningún beneficio económico por \\
\hline
\end{tabular}


participar en este estudio. Su participación es una contribución para el desarrollo de la ciencia y el conocimiento sobre la comprensión de textos verbovisuales desde un enfoque psicolingüístico. Tenga en cuenta que solo con la contribución solidaria de muchas personas como usted será posible realizar avances en las ciencias cognitivas.

PRIVACIDAD $Y$ CONFIDENCIALIDAD:

DERECHO A

RETIRARSE DEL ESTUDIO DE INVESTIGACIÓN:
La información personal que usted dará al investigador en el curso de este

estudio permanecerá en secreto y no será proporcionada a ninguna persona diferente a usted. A las encuestas, entrevistas, talleres y demás actividades se les asignará un código de tal forma que el personal técnico, diferente al docente investigador, no conocerá su identidad. El equipo general de la investigación y el personal de apoyo sólo tendrá acceso a los códigos, pero no a su identidad.

Los resultados de esta investigación pueden ser publicados en revistas científicas o ser presentados en las reuniones científicas, pero la identidad suya no será divulgada.

Usted puede retirarse del estudio en cualquier momento. Sin embargo, los datos obtenidos hasta ese momento seguirán formando parte del estudio a menos que usted solicite expresamente que su identificación y su información sea borrada de nuestra base de datos. Al retirar su participación deberá informar al grupo investigador si desea que sus respuestas sean eliminadas, los resultados de la evaluación serán incinerados.

No firme este consentimiento a menos que usted haya tenido la oportunidad de hacer preguntas y recibir contestaciones satisfactorias para todas sus preguntas.

\section{CONSENTIMIENTO}

Nombre del Participante

CC.
Firma del Investigador

CC.

Fecha: 


\section{Estudios Futuros}

Los resultados serán publicados en revistas de literatura científica garantizando que la identificación de los participantes no aparecerá en estas publicaciones. Es posible que en el futuro los resultados de su evaluación sean utilizadas para otras investigaciones cuyos objetivos y propósitos no aparecen especificados en el formato de consentimiento que usted firmará. Si esto llega a suceder, toda su información será entregada de manera codificada para garantizar que no se revelará su nombre. De igual manera, si otros grupos de investigación solicitan información para hacer estudios cooperativos, la información se enviará sólo con el código. Es decir, su identificación no saldrá de la base de datos codificada de nuestro grupo de investigación.

Yo estoy de acuerdo en autorizar que la información de los resultados de mi representado legal o mía sea utilizada en otras investigaciones en el futuro.

Nombre

Firma:

C.C.

Fecha:

NOTAS:

1. Este documento de propiedad y uso exclusivo de la investigación, la información personal de los participantes no se compartirá con otras personas para ningún fin y por ningún medio.

2. Los nombres reales se cambiarán en el cuerpo de la investigación para proteger la identidad de los sujetos. 


\section{ANEXO 7. Encuesta diagnóstica para identificar conocimiento previo de los sujetos}

A continuación se formulan nueve preguntas, es importante que prestes atención y respondas con sinceridad. No hay respuestas correctas o incorrectas. El cuestionario es anónimo. Por favor no dejes pregunta sin responder. Mil gracias.

1. Qué hace que te guste un texto y termines su lectura (pueden marcar más de una opción):
a. el argumento
e. la brevedad
b. el estilo
f. la letra
c. los personajes
g. el uso de imágenes
d. la facilidad para comprender

2. Ordeno los siguientes tipos de lectura según la regularidad con que los leo, siendo uno el más regular y 8 el menos regular:

Autoayuda

Terror

Aventuras

Animales y naturaleza
Historia

Erótica

Violencia

Amor

3. Por su extensión, el texto ideal para leer por placer tendría:

a. menos de 5 páginas 

b. entre 6 y 12 páginas
c. entre 13 y 30 páginas
d. entre 31 y 100 páginas
e. no es importante si es de mi interés

4. Prefiero la lectura de textos que tengan:
a. solo letras
d. con pocos dibujos
b. solo dibujos
e. igual cantidad de dibujos y letras
c. con muchos dibujos
f. me es indiferente si es de mi interés

5. Con qué regularidad lee los siguientes tipos de textos, marca 1 el más frecuente y 6 el menos frecuente:

_ Caricaturas
Novela gráfica
_ Cuento gráfico
Humor gráfico

6. Poseo caricaturas, novela gráfica, cuento gráfico, humor gráfico, anime, manga, en formato:
a. digital
b. físico
c. no poseo ningún formato este tipo de textos. 
ANEXO 8. Base de datos de pruebas pretest y post test del grupo estudio y

control.

\begin{tabular}{|c|c|c|c|c|c|c|c|c|c|c|c|}
\hline \multirow{2}{*}{\multicolumn{6}{|c|}{$\begin{array}{l}\text { PRUEBA PRETEST: EL TESTAMENTO DEL SEÑOR MORRIS } \\
\text { GRUPO ESTUDIO }\end{array}$}} & \multicolumn{6}{|c|}{1 = Acierto } \\
\hline & & & & & & \multicolumn{4}{|c|}{$0=$ Desacierto } & & \\
\hline & & \multicolumn{10}{|c|}{ PREGUNTAS } \\
\hline SUJETOS & CODIFICACIÓN & 1 & 2 & 3 & 4 & 5 & 6 & 7 & 8 & 9 & 10 \\
\hline CAMILA & Sujeto 1 & 1 & 1 & 0 & 0 & 0 & 0 & 0 & 1 & 0 & 0 \\
\hline DAIRO & Sujeto 2 & 1 & 1 & 0 & 1 & 1 & 0 & 0 & 0 & 1 & 0 \\
\hline DANIELA & Sujeto 3 & 1 & 1 & 0 & 1 & 0 & 1 & 1 & 1 & 0 & 0 \\
\hline DANIS & Sujeto 4 & 1 & 1 & 1 & 0 & 0 & 0 & 0 & 0 & 1 & 0 \\
\hline ELVIA & Sujeto 5 & 1 & 1 & 0 & 1 & 1 & 0 & 0 & 0 & 1 & 1 \\
\hline GERLDINE & Sujeto 6 & 1 & 1 & 0 & 0 & 0 & 0 & 0 & 1 & 0 & 1 \\
\hline LUIS FERNANDO & \begin{tabular}{|l|} 
Sujeto 7 \\
\end{tabular} & 1 & 1 & 0 & 0 & 0 & 1 & 1 & 1 & 0 & 1 \\
\hline LUZ ADRIANA & Sujeto 8 & 1 & 1 & 0 & 0 & 1 & 1 & 1 & 1 & 1 & 0 \\
\hline MARÍA FERNANDA & Sujeto 9 & 1 & 0 & 0 & 0 & 0 & 1 & 0 & 0 & 1 & 1 \\
\hline MARLON & Sujeto 10 & 1 & 1 & 0 & 1 & 0 & 0 & 0 & 1 & 1 & 1 \\
\hline \multicolumn{12}{|l|}{ GRUPO CONTROL } \\
\hline SUJETOS & CODIFICACIÓN & 1 & 2 & 3 & 4 & 5 & \begin{tabular}{|c|}
6 \\
\end{tabular} & 7 & 8 & 9 & 10 \\
\hline ANDREA & Sujeto 1 & 0 & 1 & 1 & 0 & 1 & 1 & 0 & 1 & 1 & 1 \\
\hline KAREN & Sujeto 2 & 1 & 1 & 0 & 1 & 0 & 1 & 0 & 0 & 1 & 0 \\
\hline LILIA & Sujeto 3 & 1 & 1 & 0 & 0 & 1 & 0 & 1 & 1 & 0 & 1 \\
\hline MANUEL & Sujeto 4 & 1 & 0 & 0 & 0 & 1 & 0 & 0 & 1 & 0 & 0 \\
\hline MARIA ANGELICA & Sujeto 5 & 1 & 1 & 0 & 0 & 0 & 0 & 0 & 1 & 0 & 1 \\
\hline MARIA & Sujeto 6 & 1 & 1 & 0 & 0 & 0 & 1 & 1 & 1 & 1 & 0 \\
\hline NAIVIS & Sujeto 7 & 1 & 1 & 0 & 1 & 1 & 0 & 0 & 1 & 0 & 0 \\
\hline OSCAR & Sujeto 8 & 0 & 1 & 0 & 0 & 0 & 1 & 1 & 1 & 0 & 1 \\
\hline VANESSA & Sujeto 9 & 1 & 1 & 0 & 0 & 0 & 0 & 1 & 1 & 0 & 1 \\
\hline YENIS & Sujeto 10 & 1 & 1 & 0 & 0 & 0 & 1 & 0 & 1 & 0 & 0 \\
\hline
\end{tabular}

\begin{tabular}{l} 
PRUEBA POST TEST: LA FOBIA \\
\begin{tabular}{|l|l|r|r|r|r|r|r|r|r|r|r|}
\hline GRUPO ESTUDIO \\
\hline
\end{tabular} \\
\hline
\end{tabular}


ANEXO 9. Base de datos de pruebas monitoreo grupo estudio

\begin{tabular}{|c|c|c|c|c|c|c|c|c|c|c|c|}
\hline \multicolumn{2}{|c|}{ MONITOREO 1: LA CAÑADA } & & & & & & & & & & \\
\hline \multicolumn{2}{|l|}{ GRUPO ESTUDIO } & & & & & & & & & & \\
\hline & & \multicolumn{10}{|c|}{ PREGUNTAS } \\
\hline SUJETOS & CODIFICACIÓN & 1 & 2 & 3 & 4 & 5 & 6 & 7 & 8 & 9 & 10 \\
\hline CAMILA & Sujeto 1 & 1 & 1 & 1 & 1 & 0 & 0 & 1 & 1 & 0 & 0 \\
\hline DAIRO & Sujeto 2 & 0 & 1 & 1 & 1 & 1 & 0 & 0 & 1 & 0 & 0 \\
\hline DANIELA & Sujeto 3 & 0 & 1 & 0 & 1 & 1 & 1 & 0 & 1 & 0 & 0 \\
\hline DANIS & Sujeto 4 & 1 & 1 & 1 & 0 & 0 & 1 & 1 & 1 & 1 & 0 \\
\hline ELVIA & Sujeto 5 & 0 & 1 & 1 & 1 & 0 & 1 & 1 & 0 & 0 & 0 \\
\hline GERLDINE & Sujeto 6 & 0 & 0 & 1 & 0 & 0 & 0 & 1 & 0 & 1 & 0 \\
\hline LUIS FERNANDO & Sujeto 7 & 0 & 1 & 1 & 1 & 0 & 1 & 0 & 1 & 1 & 0 \\
\hline LUZ ADRIANA & Sujeto 8 & 0 & 1 & 1 & 1 & 0 & 1 & 0 & 1 & 0 & 1 \\
\hline MARÍA FERNANDA & Sujeto 9 & 1 & 1 & 0 & 1 & 0 & 0 & 0 & 1 & 0 & 1 \\
\hline MARLON & Sujeto 10 & 1 & 1 & 1 & 0 & 0 & 1 & 0 & 0 & 0 & 0 \\
\hline
\end{tabular}

MONITOREO 2: EL MAL

GRUPO ESTUDIO

\begin{tabular}{|l|l|r|r|r|r|r|r|r|r|r|r|}
\hline & & \multicolumn{1}{|c|}{ PREGUNTAS } \\
\hline SUIETOS & CODIFICACIÓN & 1 & 2 & 3 & 4 & 5 & 6 & 7 & 8 & 9 & 10 \\
\hline CAMILA & Sujeto 1 & 1 & 0 & 0 & 0 & 0 & 1 & 1 & 0 & 1 & 1 \\
\hline DAIRO & Sujeto 2 & 1 & 1 & 1 & 1 & 0 & 1 & 0 & 1 & 1 & 0 \\
\hline DANIELA & Sujeto 3 & 1 & 1 & 0 & 1 & 1 & 0 & 1 & 0 & 1 & 1 \\
\hline DANIS & Sujeto 4 & 0 & 1 & 1 & 1 & 1 & 1 & 0 & 1 & 1 & 1 \\
\hline ELVIA & Sujeto 5 & 0 & 1 & 1 & 1 & 0 & 1 & 1 & 0 & 1 & 0 \\
\hline GERLDINE & Sujeto 6 & 1 & 0 & 1 & 1 & 1 & 0 & 1 & 1 & 1 & 0 \\
\hline LUIS FERNANDO & Sujeto 7 & 1 & 0 & 1 & 0 & 1 & 0 & 1 & 1 & 0 & 0 \\
\hline LUZ ADRIANA & Sujeto 8 & 0 & 1 & 0 & 1 & 0 & 1 & 1 & 1 & 1 & 1 \\
\hline MARIA FERNANDA & Sujeto 9 & 1 & 0 & 0 & 1 & 0 & 1 & 1 & 0 & 1 & 1 \\
\hline MARLON & Sujeto 10 & 1 & 1 & 1 & 0 & 0 & 1 & 0 & 1 & 0 & 0 \\
\hline
\end{tabular}

MONITOREO 3: ESTUPIDO HUMANO

GRUPO ESTUDIO

\begin{tabular}{|l|l|r|r|r|r|r|r|r|r|r|r|}
\hline & & \multicolumn{10}{|c|}{ PREGUNTAS } \\
\hline SUJETOS & CODIFICACIÓN & 1 & 2 & 3 & 4 & 5 & 6 & 7 & 8 & 9 & 10 \\
\hline CAMILA & Sujeto 1 & 1 & 0 & 1 & 1 & 1 & 1 & 1 & 0 & 1 & 1 \\
\hline DAIRO & Sujeto 2 & 0 & 0 & 1 & 1 & 1 & 1 & 1 & 1 & 1 & 1 \\
\hline DANIELLA & Sujeto 3 & 1 & 1 & 1 & 1 & 1 & 1 & 0 & 1 & 1 & 1 \\
\hline DANIS & Sujeto 4 & 1 & 0 & 1 & 1 & 1 & 1 & 0 & 0 & 0 & 1 \\
\hline ELVIA & Sujeto 5 & 1 & 0 & 1 & 1 & 1 & 1 & 0 & 0 & 1 & 1 \\
\hline GERLDINE & Sujeto 6 & 1 & 0 & 1 & 1 & 1 & 1 & 1 & 0 & 0 & 1 \\
\hline LUIS FERNANDO & Sujeto 7 & 1 & 0 & 1 & 1 & 1 & 1 & 0 & 1 & 1 & 1 \\
\hline LUZ ADRIANA & Sujeto 8 & 1 & 0 & 1 & 1 & 0 & 1 & 1 & 0 & 1 & 1 \\
\hline MARÍA FERNANDA & Sujeto 9 & 0 & 1 & 0 & 0 & 0 & 1 & 1 & 0 & 0 & 1 \\
\hline MARLON & Sujeto 10 & 1 & 1 & 1 & 1 & 1 & 1 & 1 & 0 & 0 & 1 \\
\hline
\end{tabular}


ANEXO 10. Ejemplos de ejercicios cognitivos (Fonseca, 1995; NGV, s. f.)

Batería 1. Búsqueda de diferencias.

Uno de los fragmentos de la fotografía es falso. ¿Cuál es?
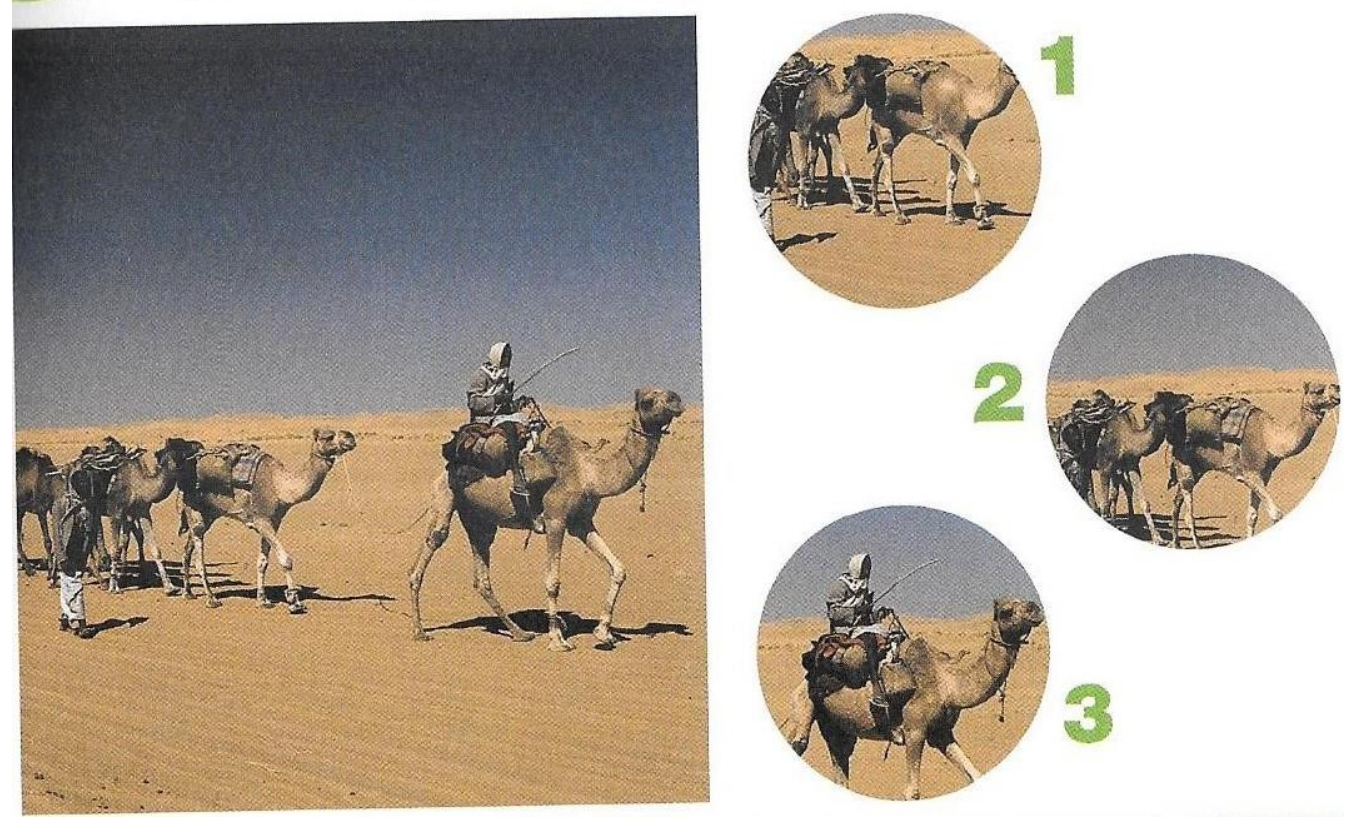

\section{Batería 2. Secuencias.}

En el rectángulo de la derecha existen 21 piezas de dominó. Abajo encontrará las piezas que se han utilizado. Identifique su posición marcando las piezas en el rectángulo.

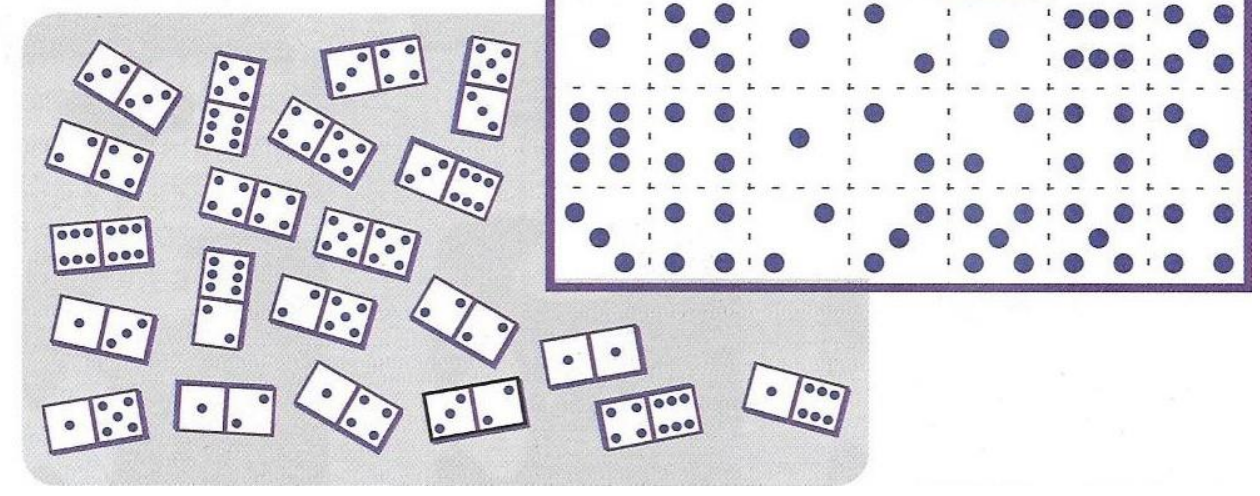


Batería 3. Razonamiento abstracto.

¿QQué figura es la misma, pero vista desde detrás?
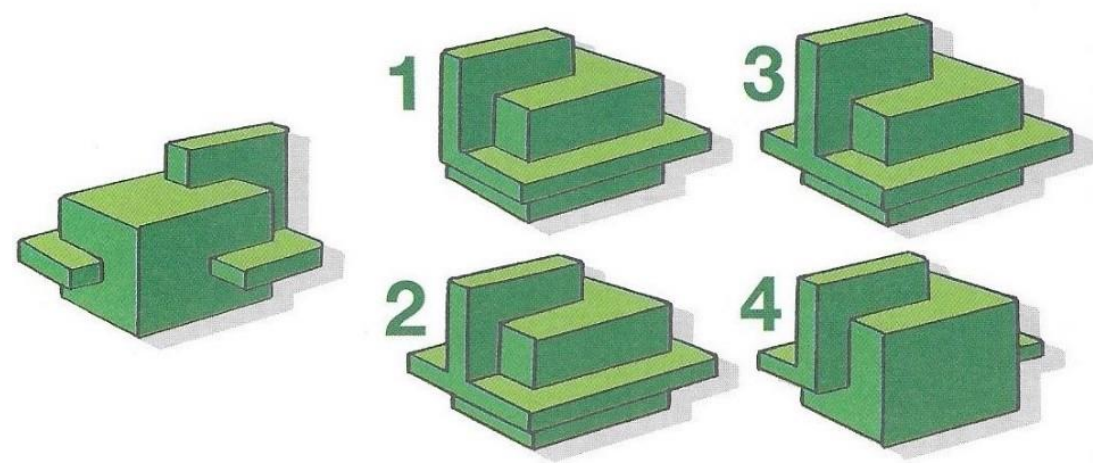

Batería 4. Rompecabezas.

Puzzle
fotográfico

¿Cuál es el orden de las cifras si colocamos las

piezas del puzzle en la posición correcta (empe-
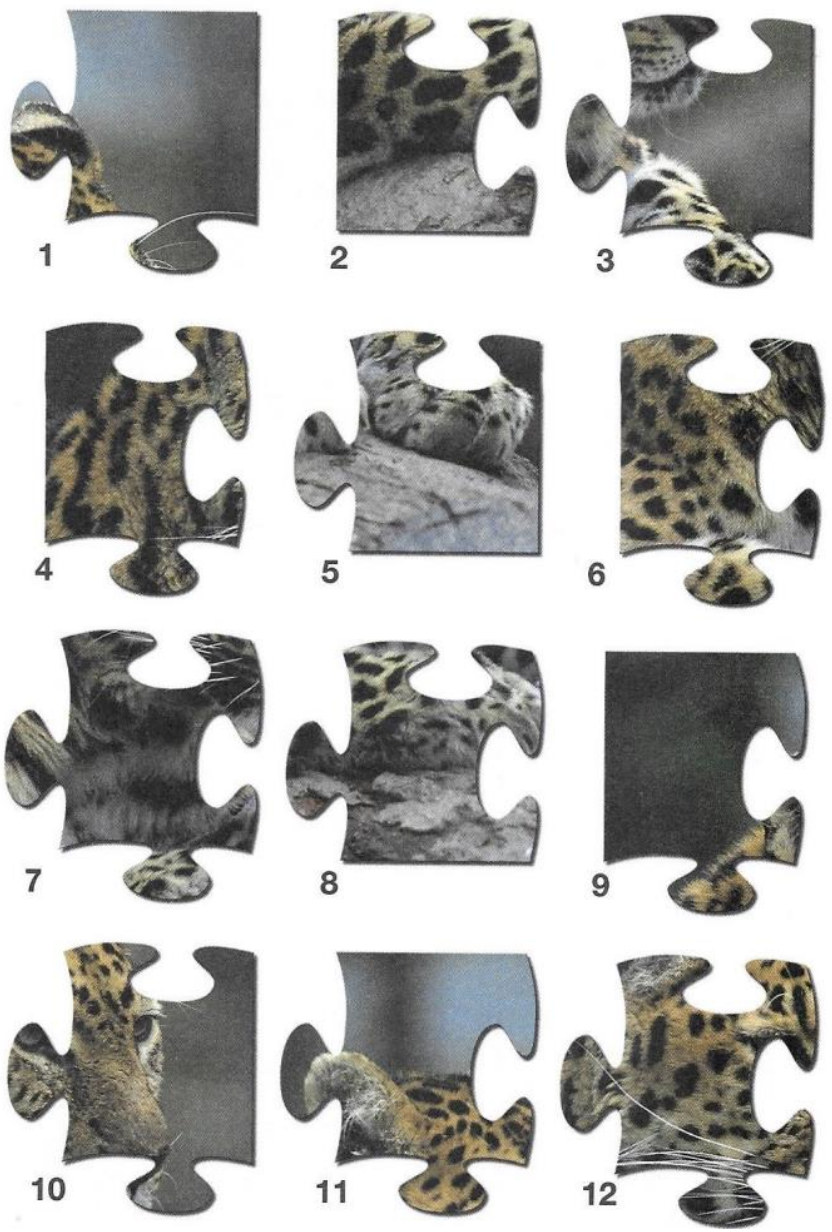
Batería 5. Selección de estímulos.

Ponga debajo de cada símbolo el número que corresponda:

\begin{tabular}{cccc|}
$\oplus$ & $\mathbb{1}$ & $\emptyset$ & $\Phi$ \\
$\mathbf{4}$ & $\mathbf{3}$ & $\mathbf{2}$ & $\mathbf{1}$ \\
\hline
\end{tabular}

\begin{tabular}{|c|c|c|c|c|c|c|c|c|c|}
\hline Ǿ & $\Phi$ & (B) & $\varnothing$ & $\Phi$ & (B) & Ǿ & $\oplus$ & ळ & $\Phi$ \\
\hline$\Phi$ & Ǿ & $\Phi$ & $\Phi$ & Ǿ & $\Phi$ & $\Phi$ & 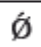 & $\oplus$ & $\Phi$ \\
\hline Ǿ & $\Phi$ & (R) & $\Phi$ & Ǿ & $(\mathbb{R}$ & $\Phi$ & $\oplus$ & $\Phi$ & $\oplus$ \\
\hline$\Phi$ & (B) & $\varnothing$ & (B) & $\Phi$ & $\Phi$ & (B) & $\oplus$ & $\oplus$ & (B) \\
\hline Ǿ & $\Phi$ & (B) & (B) & $\Phi$ & Ø & $\oplus$ & Ø & (B) & $\oplus$ \\
\hline
\end{tabular}

TOTAL: .

Una vez haya acabado, repáselo y anote la suma de números de cada fila y el total de todo el ejercido.

Las soluciones a las sumas del ejercikio son: $1^{*}$ filla: $21 \quad 4^{*}$ filla 25

$\begin{array}{ll}2^{2} \text { filla: } 16 & 5^{*} \text { filla: } 25 \\ 3^{*} \text { filla: } 22 & \text { TOTAL: } 109\end{array}$

\section{Batería 6. Memoria}

1- Observe con detenimiento la imagen de abajo.

2- Mientras la ve, vaya diciendo en voz alta lo que observa y asi se le grabará mejor. Por ejemplo, diga "en la imagen se puede ver una cocina con armarios, un lavavajillas en la parte inferior, una cafetera encima del mueble situado a la derecha,....".

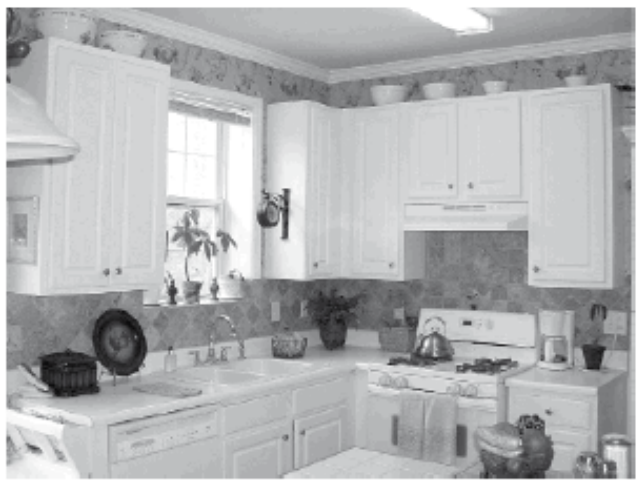

3- Cierre los ojos e imaginese la imagen durante unos instantes, tratando de recordar todos los detalles.

4- Tape con una mano la imagen y responda a estas preguntas:

¿Cuántas ventanas hay en la cocina?

¿Qué objeto está puesto en el fuego?.

¿Cuántos cuencos hay encima de los armarios?

¿Cuảntas personas hay en la imagen?...

¿Cuántas plantas en total hay en la cocina?

¿Hay algún grifo en la imagen? ¿Dónde se encuentra)

¿Qué objeto hay colgado de un armario? 


\section{Batería 7. Percepción.}

1- Observe el sigulente cuadroe intente averiguar qué objetos se encuentran escondidos:

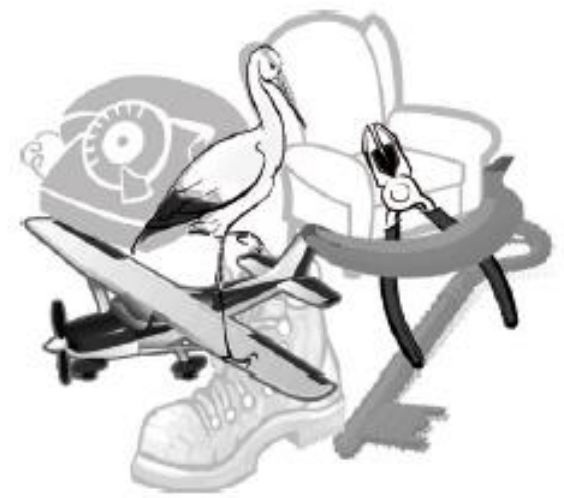

2- Intente responder a las sigulentes res puestas:
A. ¿Qué herramlenta aparece en el dibujo?
B. ¿Qué prenda de vestir?
C. jQué medlo de transporte?
D. ¿Qué mueble?
E. ¿Qué animal?
F. ¿Que objeto para abrir ka puerta?
G. ¡Qué frutal
H. ¡Qué medio de comunicadón?

\section{> Batería 8. Laberintos.}

Empezando en el cuadrado de abajo que está sombreado, busca un camino que te lleve al pentágono marcado en el centro. La regla es la siguiente: Puedes moverte hacia 1 . arriba, hacia Jabajo, a la derecha, a la siempre que ésta tenga la misma figura o el mismo color que la casilla en donde estás.

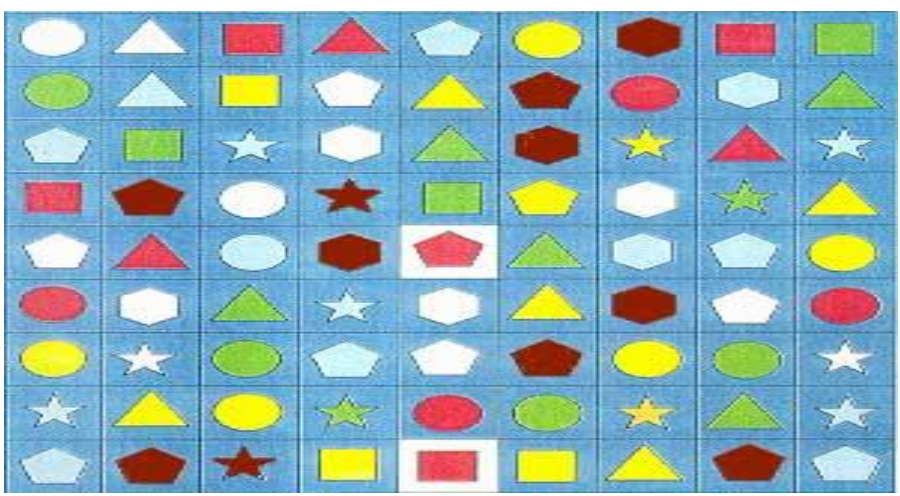




\section{ANEXO 11. Rúbricas para construcción de pruebas.}

Prueba pretest: El testamento del señor Morris (Boix, 2009, pp. 59-65)

\begin{tabular}{|c|c|c|c|c|c|c|c|c|c|c|c|c|}
\hline \begin{tabular}{|l|} 
INDEPENDI \\
ENTE \\
\end{tabular} & INDICADORES & SUB-INDICADORES & 1 & 2 & 3 & 4 & 5 & 6 & 7 & 8 & $\mathbf{9}$ & 10 \\
\hline \multirow{10}{*}{$\begin{array}{l}\text { IMAGGEN } \\
\text { VISUAL }\end{array}$} & \multirow{3}{*}{$\begin{array}{l}\text { ANNÉLISIS } \\
\text { DENOTATIVO }\end{array}$} & 1. Elementos escalares (tamaño y espacio) & $x$ & $x$ & $x$ & \begin{tabular}{|l|l}
$x$ \\
\end{tabular} & \begin{tabular}{|l|l}
$x$ \\
$x$
\end{tabular} & \begin{tabular}{l|l} 
\\
$x$
\end{tabular} & \begin{tabular}{l|l}
$x$ \\
\end{tabular} & $x$ & $x$ & $x$ \\
\hline & & $\begin{array}{l}\text { 2. Elementos morfológicos (punto, línea, } \\
\text { color, luz, contraste, textura, forma) }\end{array}$ & $x$ & $x$ & $x$ & $x$ & $x$ & $\bar{x}$ & $\bar{x}$ & $x$ & $x$ & $x$ \\
\hline & & $\begin{array}{l}\text { 3. Elementos dinámicos (composición, ritmo, } \\
\text { encuadre, angulación, planos, profundidad, } \\
\text { gutter) }\end{array}$ & $x$ & $x$ & $x$ & $x$ & $x$ & $x$ & $x$ & $x$ & $x$ & $x$ \\
\hline & \multirow{4}{*}{$\begin{array}{l}\text { ANŔLISIS } \\
\text { CONNOTATIVO } \\
\text { (creencias, } \\
\text { conocimientos y } \\
\text { estados anímicos) }\end{array}$} & 1. Intención del autor & & & & & & $x$ & $x$ & $x$ & $x$ & $x$ \\
\hline & & 2. Público del tento & $x$ & & & & & $x$ & & & & $x$ \\
\hline & & 3. Objetivos de la imagen & & & & & & & $x$ & $x$ & $x$ & $x$ \\
\hline & & 4. Estereotipo, prejuicios, discriminación & & & & & & & & & & \\
\hline & \multirow[t]{3}{*}{$\begin{array}{c}\text { ANÁLISIS } \\
\text { CONCEPTUALL }\end{array}$} & $\begin{array}{l}\text { 1. Función o acción de los elementos de una } \\
\text { imagen (descriptiva, informativa, estética, } \\
\text { expresiva, sugestiva). }\end{array}$ & & & & & & $x$ & $x$ & $x$ & $x$ & $x$ \\
\hline & & $\begin{array}{l}\text { 2. Anclaje de la imagen en el contento: ¿qué } \\
\text { función cumple? ¿a quién va dirigida? ¿en que } \\
\text { contento social, político o económico se sitúa? } \\
\text { ¿cuál es el significado final que el autor nos } \\
\text { quiere comunicar? }\end{array}$ & $x$ & & & $x$ & & $x$ & $\mathrm{x}$ & & & \\
\hline & & $\begin{array}{l}\text { 3. Nivel de representación (iconicidad), modos } \\
\text { de expresión según la época. }\end{array}$ & & & & & & $x$ & $x$ & & & \\
\hline \multirow[t]{8}{*}{\begin{tabular}{|l|} 
CLAVES \\
LINGUISTICAS
\end{tabular}} & $\begin{array}{l}\text { SUPERESTRULTU } \\
\text { RALL }\end{array}$ & $\begin{array}{l}\text { Cuento gráfico: introducción, complicación y } \\
\text { resolución }\end{array}$ & & & & & & $x$ & $x$ & & & \\
\hline & \multirow{4}{*}{$\begin{array}{l}\text { MICROESTRUCTU } \\
\text { RAL (relaciones } \\
\text { sentencialese } \\
\text { intersentenciales) }\end{array}$} & Sinonimia (sustitución léxica) & & & & & & & & & & \\
\hline & & Elipsis & & & & & & & & & & \\
\hline & & Puntuación & & & & & & & & & & \\
\hline & & Referencias: pronominalización & $x$ & & & & & & & & & \\
\hline & \multirow[t]{3}{*}{ MACROESTRUCTU } & $\begin{array}{l}\text { Reglas de transformación [suprimir, construir, } \\
\text { fusionar [generalizar]) }\end{array}$ & & $x$ & $x$ & & & & $\bar{x}$ & & & \\
\hline & & $\begin{array}{l}\text { Información (cantidad, calidad, completa, } \\
\text { estructurada) }\end{array}$ & & $x$ & $x$ & & & & $x$ & & & \\
\hline & & $\begin{array}{l}\text { Coherencia (manejo de información, } \\
\text { recurrencia [temalrema], perírrasis y } \\
\text { correlaciones, presuposición] }\end{array}$ & & $x$ & $x$ & & & & $\bar{x}$ & & & \\
\hline & & & & & & & & & & & & \\
\hline & $\begin{array}{l}\text { VARIABLE } \\
\text { DEPENDIENTE }\end{array}$ & INDICADORES & 1 & 2 & 3 & 4 & 5 & 6 & 7 & 8 & 9 & 10 \\
\hline & \multirow{3}{*}{ Comprensión } & Recuperación de información (muestreo) & $x$ & $x$ & $x$ & $x$ & $x$ & $x$ & $x$ & $x$ & $x$ & $x$ \\
\hline & & $\begin{array}{l}\text { Producción de inferencias (predicción y } \\
\text { anticipación) }\end{array}$ & $x$ & $x$ & $x$ & $x$ & $x$ & $x$ & $x$ & $x$ & $x$ & $x$ \\
\hline & & $\begin{array}{l}\text { Reflexión y evaluación de la información } \\
\text { (confirmación y autocorrección) }\end{array}$ & & $x$ & $x$ & & $x$ & $x$ & $x$ & & & $x$ \\
\hline & & \multicolumn{10}{|c|}{ Para responder los sujetos deben relacionar las imágenes visuales y las claves linguísticas. } & \\
\hline & & \multicolumn{11}{|c|}{ Para responder los sujetos deben centrarse en las imágenes visuales } \\
\hline & & \multicolumn{11}{|c|}{ Para responder los sujetos deben centrarse en las las claves linguísticas. } \\
\hline
\end{tabular}


Prueba post test: La fobia (Boix, 2009, pp. 91-98)

\begin{tabular}{|c|c|c|c|c|c|c|c|c|c|c|c|c|}
\hline $\begin{array}{l}\text { YARIABLE } \\
\text { INDEPENDI } \\
\text { ENTE } \\
\end{array}$ & INDICADORES & SUB-INDICADORES & 1 & 2 & 3 & 4 & 5 & 6 & 7 & 8 & 9 & 10 \\
\hline \multirow{10}{*}{$\begin{array}{l}\text { IMAGEN } \\
\text { VISUAL }\end{array}$} & \multirow{3}{*}{$\begin{array}{l}\text { ANNÉLISIS } \\
\text { DENOTATIVO }\end{array}$} & 1. Elementos escalares (tamañ́o y espacio) & $x$ & $x$ & $x$ & $x$ & $x$ & $x$ & $x$ & $x$ & $x$ & $x$ \\
\hline & & $\begin{array}{l}\text { 2. Elementos morfológicos (punto, línea, color, } \\
\text { luz, contraste, textura, forma) }\end{array}$ & $x$ & $x$ & $x$ & $x$ & $x$ & $x$ & $x$ & $x$ & $x$ & $x$ \\
\hline & & $\begin{array}{l}\text { 3. Elementos dinámicos (composición, ritmo, } \\
\text { encuadre, angulación, planos, profundidad, gutter) }\end{array}$ & $x$ & $x$ & $x$ & $x$ & $x$ & $x$ & $\bar{x}$ & $x$ & $x$ & $x$ \\
\hline & \multirow{4}{*}{$\begin{array}{l}\text { ANAŔLISIS } \\
\text { CONNOTATIVO } \\
\text { (creencias, } \\
\text { conocimientos y } \\
\text { estados } \\
\text { anímicos) }\end{array}$} & 1. Intención del autor & $x$ & & & & $x$ & $x$ & $x$ & $x$ & $x$ & $\bar{x}$ \\
\hline & & 2. Público del tento & & & & & & & & & & \\
\hline & & 3. Objetivos de la imagen & $x$ & & $\mathrm{x}$ & & $x$ & $x$ & $\mathrm{x}$ & $\mathrm{x}$ & $x$ & $\mathrm{X}$ \\
\hline & & 4. Estereotipo, prejuicios, discriminación & & & & & & & & & & \\
\hline & \multirow[t]{3}{*}{$\begin{array}{c}\text { ANNÉLISIS } \\
\text { CONCEPTUAL }\end{array}$} & $\begin{array}{l}\text { 1. Función o acción de los elementos de una } \\
\text { imagen (descriptiva, informativa, estética, } \\
\text { expresiva, sugestiva). }\end{array}$ & $x$ & $x$ & $x$ & $x$ & $x$ & $x$ & $\bar{x}$ & $x$ & $x$ & $x$ \\
\hline & & $\begin{array}{l}\text { 2. Anclaje de la imagen en el contento: ¿qué } \\
\text { función cumple? ¿a quién va dirigida? ¿en que } \\
\text { conterto social, político o económico se sitúa? } \\
\text { ¿cuál es el significado final que el autor nos quiere } \\
\text { comunicar? }\end{array}$ & $x$ & $x$ & & $x$ & & $x$ & & $x$ & $x$ & $x$ \\
\hline & & $\begin{array}{l}\text { 3. Nivel de representación (iconicidad), modos de } \\
\text { expresión según la época. }\end{array}$ & & & & & & & & & & \\
\hline \multirow[t]{8}{*}{$\begin{array}{l}\text { CLAVES } \\
\text { LINGUISTICAS }\end{array}$} & $\begin{array}{l}\text { SUPERESTRUCT } \\
\text { URALL }\end{array}$ & $\begin{array}{l}\text { Cuento gráfico: introducción, complicación y } \\
\text { resolución }\end{array}$ & & & & & & & & & & \\
\hline & \multirow{4}{*}{$\begin{array}{l}\text { MICROESTRUCT } \\
\text { URALL (relaciones } \\
\text { sentencialese } \\
\text { intersentenciales) }\end{array}$} & Sinonimia [sustitución léxica) & & & & & & & $x$ & $x$ & & \\
\hline & & Elipsis & & & & & & & & & & \\
\hline & & Puntuación & & & & & & & & & & \\
\hline & & Referencias: pronominalización & & & & & & & $x$ & $x$ & & \\
\hline & \multirow[t]{3}{*}{$\begin{array}{l}\text { MACROESTRIUC } \\
\text { TURALL }\end{array}$} & $\begin{array}{l}\text { Reglas de transformación (suprimir, construir, } \\
\text { fusionar [generalizar]) }\end{array}$ & $x$ & & & & $x$ & & & & & $\bar{x}$ \\
\hline & & $\begin{array}{l}\text { Información (cantidad, calidad, completa, } \\
\text { estructurada) }\end{array}$ & $x$ & & & & $x$ & & & & & $\bar{x}$ \\
\hline & & $\begin{array}{l}\text { Coherencia (manejo de información, recurrencia } \\
\text { [tematrema], perífrasis y correlaciones. } \\
\text { presuposición ] }\end{array}$ & $x$ & & & & $x$ & & & & & $x$ \\
\hline & & & & & & & & & & & & \\
\hline & \begin{tabular}{|l|} 
DEPENDIENT \\
E \\
\end{tabular} & INDICADORES & 1 & 2 & 3 & 4 & 5 & 6 & 7 & 8 & 9 & 10 \\
\hline & \multirow{3}{*}{ Comprensión } & Recuperación de información (muestreo) & $x$ & $x$ & $\mathrm{x}$ & $x$ & $x$ & $x$ & $\mathrm{x}$ & $x$ & $x$ & $\mathrm{x}$ \\
\hline & & $\begin{array}{l}\text { Producción de inferencias (predicción y } \\
\text { anticipación] }\end{array}$ & $x$ & $x$ & $x$ & $x$ & $\mathrm{x}$ & $x$ & $x$ & $x$ & $x$ & $x$ \\
\hline & & $\begin{array}{l}\text { Reflexión y evaluación de la información } \\
\text { [confirmación y autocorrección] }\end{array}$ & $x$ & & & & $x$ & $x$ & & & $x$ & $x$ \\
\hline & & \multirow{2}{*}{\multicolumn{10}{|c|}{ Para responder los sujetos deben relacionar las imágenes visuales y las claves lingiísticas. }} & \\
\hline & & & & & & & & & & & & \\
\hline & & \multicolumn{11}{|c|}{ Para responder los sujetos deben centrarse en las imágenes visuales } \\
\hline & & \multicolumn{11}{|c|}{ Para responder los sujetos deben centrarse en las las claves linguísticas. } \\
\hline
\end{tabular}


Monitoreo 1: El secreto de la cañada de Macarger (Lalia, 2008B, pp. 73-79)

\begin{tabular}{|c|c|c|c|c|c|c|c|c|c|c|c|c|}
\hline $\begin{array}{l}\text { VARIABLE } \\
\text { INDEPENDIE }\end{array}$ & INDICADORES & SUB-INDICADQRES & 1 & 2 & 3 & 4 & 5 & 6 & 7 & 8 & 9 & 10 \\
\hline \multirow{10}{*}{$\begin{array}{l}\text { IMAGEN } \\
\text { UISUAL }\end{array}$} & \multirow{3}{*}{$\begin{array}{l}\text { ANÁLISIS } \\
\text { DENOTATIVO }\end{array}$} & 1. Elementos escalares (tamaño y espacio) & $x$ & $x$ & $x$ & $x$ & $x$ & $x$ & $x$ & $x$ & $x$ & $x$ \\
\hline & & $\begin{array}{l}\text { 2. Elementos morfológicos (punto, línea, color, } \\
\text { luz, contraste, textura, forma) }\end{array}$ & $x$ & $x$ & $x$ & $x$ & $x$ & $x$ & $x$ & $x$ & $x$ & $x$ \\
\hline & & $\begin{array}{l}\text { 3. Elementos dinámicos (composición, ritmo, } \\
\text { encuadre, angulación, planos, profundidad, } \\
\text { gutter) }\end{array}$ & $x$ & $x$ & $x$ & $x$ & $x$ & $x$ & $x$ & $x$ & $x$ & $x$ \\
\hline & \multirow{4}{*}{$\begin{array}{l}\text { ANÁLISIS } \\
\text { CONNDTATIVO } \\
\text { (creencias, } \\
\text { conocimientosy } \\
\text { estados anímicos) }\end{array}$} & 1. Intención del autor & $x$ & & $x$ & & & & & & & \\
\hline & & 2. Público del texto & $x$ & & $x$ & & & & & & & \\
\hline & & 3. Objetivos de la imagen & $x$ & $x$ & $x$ & $x$ & $x$ & $x$ & & $x$ & $x$ & $x$ \\
\hline & & 4. Estereotipo, prejuicios, discriminación & & & & & & & & & & \\
\hline & \multirow[t]{3}{*}{$\begin{array}{c}\text { ANALLISIS } \\
\text { CONCEPTUAL }\end{array}$} & $\begin{array}{l}\text { 1. Función o acción de los elementos de una } \\
\text { imagen (descriptiva, informativa, estética, } \\
\text { expresiva, sugestiva). }\end{array}$ & $x$ & & $x$ & $x$ & $x$ & $x$ & $x$ & $x$ & $x$ & $x$ \\
\hline & & $\begin{array}{l}\text { 2. Anclaje de la imagen en el conteuto: ¿qué } \\
\text { función cumple? ¿a quién va dirigida? ¿en que } \\
\text { contento social, político o económico se sitúa? } \\
\text { ¿cuál es el significado final que el autor nos } \\
\text { quiere comunicar? }\end{array}$ & & & & $x$ & $x$ & $x$ & $x$ & $x$ & $x$ & $x$ \\
\hline & & $\begin{array}{l}\text { 3. Nivel de representación (iconicidad), modos } \\
\text { de expresión según la época. }\end{array}$ & & & & $x$ & & & $x$ & & & \\
\hline \multirow[t]{17}{*}{\begin{tabular}{|l|} 
CLAVES \\
LINGUISTICAS
\end{tabular}} & $\begin{array}{l}\text { SUPERESTRUCTUR } \\
\text { AL }\end{array}$ & $\begin{array}{l}\text { Cuento gráfico: introducción, complicacióny } \\
\text { resolución }\end{array}$ & & & & & & & & & & \\
\hline & \multirow{4}{*}{$\begin{array}{l}\text { MICROESTRUCTUR } \\
\text { AL (relaciones } \\
\text { sentencialese } \\
\text { intersentenciales) }\end{array}$} & Sinonimia (sustitución léxica) & & $x$ & & $x$ & $x$ & $x$ & & $x$ & $x$ & $x$ \\
\hline & & Elipsis & & & & & & & & & & \\
\hline & & Puntuación & & & & & & & & & & \\
\hline & & Referencias: pronominalización & & $x$ & & $x$ & $x$ & $x$ & & $x$ & $x$ & $x$ \\
\hline & \multirow[t]{3}{*}{$\begin{array}{l}\text { MACROESTRIDCTUR } \\
\text { AL }\end{array}$} & $\begin{array}{l}\text { Reglas de transformación (suprimir, construir, } \\
\text { fusionar [generalizar]) }\end{array}$ & $x$ & & $x$ & & & & & & & \\
\hline & & \begin{tabular}{|l|} 
Información (cantidad, calidad, completa, \\
estructurada)
\end{tabular} & $x$ & & $x$ & & & & & & & \\
\hline & & $\begin{array}{l}\text { Coherencia (manejo de información, recurrencia } \\
\text { [temairema], perífrasis y correlaciones, } \\
\text { presuposición] }\end{array}$ & $x$ & & $x$ & & & & & & & \\
\hline & & & & & & & & & & & & \\
\hline & $\begin{array}{l}\text { VARIABLE } \\
\text { DEPENDIENTE }\end{array}$ & INDICADORES & 1 & 2 & 3 & 4 & 5 & 6 & 7 & 8 & 9 & 10 \\
\hline & \multirow{3}{*}{ Comprensión } & Recuperación de información (muestreo) & $x$ & $x$ & $x$ & $x$ & $x$ & $x$ & $x$ & $x$ & $x$ & $x$ \\
\hline & & $\begin{array}{l}\text { Producción de inferencias (prediccióny } \\
\text { anticipación) }\end{array}$ & $x$ & $x$ & $x$ & $x$ & $x$ & $x$ & $x$ & $x$ & $x$ & $x$ \\
\hline & & $\begin{array}{l}\text { Reflexión y evaluación de la información } \\
\text { (confirmacióny autocorrección) }\end{array}$ & $x$ & & $x$ & $x$ & & & & & & \\
\hline & & & & & & & & & & & & \\
\hline & & \multicolumn{11}{|c|}{ Para responder los sujetos deben relacionar las imágenes visuales y la } \\
\hline & & \multicolumn{11}{|c|}{ Para responder los sujetos deben centrarse en las imágenes visuales } \\
\hline & & \multicolumn{11}{|c|}{ Para responder los sujetos deben centrarse en las las claves lingüísticas. } \\
\hline
\end{tabular}


Monitoreo 2: El mal (Boix, 2009, pp. 86-90)

\begin{tabular}{|c|c|c|c|c|c|c|c|c|c|c|c|c|}
\hline $\begin{array}{l}\text { YARIABLE } \\
\text { INDEPENDI }\end{array}$ & $\begin{array}{l}\text { ITDICADOR } \\
\text { ES } \\
\end{array}$ & SUB-INDICADORES & 1 & 2 & 3 & 4 & 5 & 6 & 7 & 8 & 9 & 10 \\
\hline \multirow{10}{*}{$\begin{array}{l}\text { IMAGEN } \\
\text { VISUAL }\end{array}$} & \multirow{3}{*}{$\begin{array}{l}\text { ANŔLLISIS } \\
\text { DENOTATIVO }\end{array}$} & 1. Elementos escalares (tamaño y espacio) & $x$ & & $x$ & $x$ & & $x$ & $x$ & & $x$ & $x$ \\
\hline & & $\begin{array}{l}\text { 2. Elementos morfológicos (punto, línea, color, } \\
\text { luz, contraste, teatura, forma) }\end{array}$ & $x$ & & $x$ & $x$ & & $x$ & $x$ & & $x$ & $x$ \\
\hline & & $\begin{array}{l}\text { 3. Elementos dinámicos [composición, ritmo, } \\
\text { encuadre, angulación, planos, profundidad, gutter] }\end{array}$ & $x$ & & $x$ & $x$ & & $x$ & $x$ & & $x$ & $x$ \\
\hline & \multirow{4}{*}{$\begin{array}{l}\text { ANÁLLISIS } \\
\text { CONNOTATIVO } \\
\text { (creencias, } \\
\text { conocimientos y } \\
\text { estados } \\
\text { anímicos) }\end{array}$} & 1. Intención del autor & $x$ & & & & & $x$ & $x$ & & $x$ & $x$ \\
\hline & & 2. Público del terto & $x$ & & & $x$ & & $x$ & & & & \\
\hline & & 3. Objetivos de la imagen & $x$ & & $x$ & & & $x$ & $x$ & & $x$ & $x$ \\
\hline & & 4. Estereotipo, prejuicios, discriminación & & & & & & & & & & \\
\hline & \multirow[t]{3}{*}{$\begin{array}{c}\text { ANÁLISIS } \\
\text { CONCEPTUAL }\end{array}$} & $\begin{array}{l}\text { 1. Función o acción de los elementos de una } \\
\text { imagen (descriptiva, informativa, estética, } \\
\text { expresiva, sugestiva]. }\end{array}$ & $x$ & & $x$ & & & $x$ & $x$ & & $x$ & $x$ \\
\hline & & $\begin{array}{l}\text { 2. Anclaje de la imagen en el contento: ¿qué } \\
\text { función cumple? ¿a quién va dirigida? ¿en que } \\
\text { contento social, político o económico se sitúa? } \\
\text { ¿cuál es el significado final que el autor nos quiere } \\
\text { comunicar? }\end{array}$ & & & $x$ & $x$ & & $x$ & $x$ & & & $x$ \\
\hline & & $\begin{array}{l}\text { 3. Nivel de representación (iconicidad), modos de } \\
\text { expresión según la época. }\end{array}$ & & & & & & & $\bar{x}$ & & & $x$ \\
\hline \multirow[t]{8}{*}{$\begin{array}{l}\text { CLAVES } \\
\text { LINGUISTICAS }\end{array}$} & \multirow{5}{*}{$\begin{array}{l}\text { SUPERESTRU } \\
\text { CTURAL } \\
\text { MICROESTRU } \\
\text { CTURAL } \\
\text { (relaciones } \\
\text { sentencialese } \\
\text { intersentenciale } \\
\text { s) }\end{array}$} & $\begin{array}{l}\text { Cuento gráfico: introducción, complicación y } \\
\text { resolución }\end{array}$ & & & & & & & & & & \\
\hline & & Sinonimia [sustitución léxica) & & $x$ & $x$ & & $x$ & & & & & \\
\hline & & Elipsis & & & & & & & & & & \\
\hline & & Puntuación & & & & & & & & & & \\
\hline & & Referencias: pronominalización & & & $x$ & & & & & & & \\
\hline & \multirow[t]{3}{*}{$\begin{array}{l}\text { MACROESTRU } \\
\text { CTURAL }\end{array}$} & $\begin{array}{l}\text { Reglas de transformación (suprimir, construir, } \\
\text { fusionar [generalizar]] }\end{array}$ & $x$ & & & & & $x$ & & $\bar{x}$ & & $x$ \\
\hline & & $\begin{array}{l}\text { Información (cantidad, calidad, completa, } \\
\text { estructurada) }\end{array}$ & $x$ & & & & & $x$ & & $\mathrm{x}$ & & $x$ \\
\hline & & $\begin{array}{l}\text { Coherencia (manejo de información, recurrencia } \\
\text { [temarrema], perífrasis y correlaciones, } \\
\text { presuposición] }\end{array}$ & $x$ & & & & & $x$ & & $\bar{x}$ & & $x$ \\
\hline & & & & & & & & & & & & \\
\hline & $\begin{array}{l}\text { DEPENDIEN } \\
\text { TE }\end{array}$ & INDICADORES & 1 & 2 & 3 & 4 & 5 & 6 & 7 & 8 & $\mathbf{9}$ & 10 \\
\hline & \multirow{3}{*}{ Comprensión } & Recuperación de información (muestreo) & $x$ & $x$ & $x$ & $x$ & $x$ & $x$ & $x$ & $x$ & $\mathrm{x}$ & $x$ \\
\hline & & $\begin{array}{l}\text { Producción de inferencias (predicción y } \\
\text { anticipación) }\end{array}$ & $x$ & $x$ & $x$ & $x$ & $x$ & $x$ & $x$ & $x$ & $x$ & $x$ \\
\hline & & $\begin{array}{l}\begin{array}{l}\text { Reflexión y evaluación de la información } \\
\text { (confirmación y autocorrección) }\end{array} \\
\end{array}$ & $x$ & & & & & $x$ & & $x$ & & $x$ \\
\hline & & & & & & & & & & & & \\
\hline & & \multicolumn{10}{|c|}{ Para responder los sujetos deben relacionar las imágenes visuales y la } & \\
\hline & & \multicolumn{11}{|c|}{ Para responder los sujetos deben centrarse en las imágenes visuales } \\
\hline & & \multicolumn{11}{|c|}{ Para responder los sujetos deben centrarse en las las claves linguísticas. } \\
\hline
\end{tabular}




\section{Monitoreo 3: El estúpido humano (Boix, 2009, pp.78-85)}

\begin{tabular}{|c|c|c|c|c|c|c|c|c|c|c|c|c|}
\hline \begin{tabular}{|l|} 
VARIABLE \\
INDEPENDIE \\
NTE
\end{tabular} & INDICADORES & SUB-INDICADORES & 1 & 2 & 3 & 4 & 5 & 6 & 7 & 8 & 9 & 10 \\
\hline \multirow{10}{*}{$\begin{array}{l}\text { IMAGEN } \\
\text { VISUAL }\end{array}$} & \multirow{3}{*}{$\begin{array}{l}\text { ANÁLISIS } \\
\text { DENOTATIVO }\end{array}$} & 1. Elementos escalares (tamaño y espacio) & $x$ & $x$ & $x$ & $x$ & $x$ & $x$ & $x$ & $x$ & $x$ & $x$ \\
\hline & & $\begin{array}{l}\text { 2. Elementos morfológicos (punto, línea, color, } \\
\text { luz, contraste, textura, forma) }\end{array}$ & $x$ & $x$ & $x$ & $x$ & $x$ & $x$ & $x$ & $x$ & $x$ & $x$ \\
\hline & & $\begin{array}{l}\text { 3. Elementos dinámicos (composición, ritmo, } \\
\text { encuadre, angulación, planos, profundidad, } \\
\text { gutter) }\end{array}$ & $x$ & $x$ & $x$ & $x$ & $x$ & $x$ & $x$ & $x$ & $x$ & $x$ \\
\hline & \multirow{4}{*}{$\begin{array}{l}\text { ANÁLISIS } \\
\text { CONNDTATIVO } \\
\text { (creencias, } \\
\text { conocimientosy } \\
\text { estados anímicos) }\end{array}$} & 1. Intención del autor & $x$ & $x$ & $x$ & $x$ & $x$ & $x$ & $x$ & $x$ & $x$ & $x$ \\
\hline & & 2. Público del texto & & & & & & & & & & \\
\hline & & 3. Objetivos de la imagen & $x$ & $x$ & $x$ & $x$ & $x$ & $x$ & $x$ & $x$ & $x$ & $x$ \\
\hline & & 4. Estereotipo, prejuicios, discriminación & & & & & & & & & & \\
\hline & \multirow[t]{3}{*}{$\begin{array}{c}\text { ANÁLISIS } \\
\text { CONCEPTUAL }\end{array}$} & $\begin{array}{l}\text { 1. Función o acción de los elementos de una } \\
\text { imagen (descriptiva, informativa, estética, } \\
\text { expresiva, sugestiva]. }\end{array}$ & $x$ & $x$ & $x$ & $x$ & $x$ & & $x$ & $x$ & $x$ & $x$ \\
\hline & & $\begin{array}{l}\text { 2. Anclaje de la imagen en el contexto: ¿qué } \\
\text { función cumple? ¿a quién va dirigida? ¿en que } \\
\text { contexto social, político o económico se sitúa? } \\
\text { ¿cuál es el significado final que el autor nos quiere } \\
\text { comunicar? }\end{array}$ & $x$ & $x$ & $x$ & $x$ & $x$ & & $x$ & & $x$ & $x$ \\
\hline & & $\begin{array}{l}\text { 3. Nivel de representación (iconicidad), modos de } \\
\text { expresión según la época. }\end{array}$ & & & & & & & & & & \\
\hline \multirow[t]{8}{*}{$\begin{array}{l}\text { CLAUES } \\
\text { LINGUISTICAS }\end{array}$} & $\begin{array}{l}\text { SUPERESTRUCT } \\
\text { URAL } \\
\end{array}$ & $\begin{array}{l}\text { Cuento gráfico: introducción, complicacióny } \\
\text { resolución }\end{array}$ & & & & & & & & & & \\
\hline & \multirow{4}{*}{$\begin{array}{l}\text { MICROESTRUCTU } \\
\text { RAL (relaciones } \\
\text { sentencialese } \\
\text { intersentenciales) }\end{array}$} & Sinonimia (sustitución léxica) & & & & & $x$ & & & & $x$ & \\
\hline & & Elipsis & & & & & & & & & & \\
\hline & & Puntuación & & & & & & & & & & \\
\hline & & Referencias: pronominalización & & & & & $x$ & & & & $x$ & \\
\hline & \multirow[t]{3}{*}{$\begin{array}{l}\text { MACROESTRUCT } \\
\text { URALL }\end{array}$} & $\begin{array}{l}\text { Reglas de transformación (suprimir, construir, } \\
\text { fusionar [generalizar]) }\end{array}$ & $x$ & $x$ & $x$ & $x$ & & $x$ & $x$ & & & $x$ \\
\hline & & $\begin{array}{l}\text { Información (cantidad, calidad, completa, } \\
\text { estructurada) }\end{array}$ & $x$ & $x$ & $x$ & $x$ & & $x$ & $x$ & & & $x$ \\
\hline & & $\begin{array}{l}\text { Coherencia (manejo de información, recurrencia } \\
\text { [temalrema], perífrasis y correlaciones, } \\
\text { presuposición] }\end{array}$ & $x$ & $x$ & $x$ & $x$ & & $x$ & $x$ & & & $x$ \\
\hline & & & & & & & & & & & & \\
\hline & $\begin{array}{l}\text { VARIABLE } \\
\text { DEPENDIENTE } \\
\end{array}$ & INDICADORES & 1 & 2 & 3 & 4 & 5 & 6 & 7 & 8 & 9 & 10 \\
\hline & \multirow{3}{*}{ Comprensión } & Recuperación de información (muestreo) & $x$ & $x$ & $x$ & $x$ & $x$ & $x$ & $x$ & $x$ & $x$ & $x$ \\
\hline & & $\begin{array}{l}\text { Producción de inferencias (prediccióny } \\
\text { anticipación) }\end{array}$ & $x$ & $x$ & $x$ & $x$ & $x$ & $x$ & $x$ & $x$ & $x$ & $x$ \\
\hline & & $\begin{array}{l}\begin{array}{l}\text { Reflexión y evaluación de la información } \\
\text { (confirmación y autocorrección) }\end{array} \\
\end{array}$ & $x$ & $x$ & & & & $x$ & $x$ & & & \\
\hline & & & & & & & & & & & & \\
\hline & & \multicolumn{10}{|c|}{ Para responder los sujetos deben relacionar las imágenes visuales y las claves lingüísticas. } & \\
\hline & & \multicolumn{11}{|c|}{ Para responder los sujetos deben centrarse en las imágenes visuales } \\
\hline & & \multicolumn{11}{|c|}{ Para responder los sujetos deben centrarse en las las claves lingüísticas. } \\
\hline
\end{tabular}

